\title{
ANÁLISE GENÉTICA DE CARACTERES QUANTITATIVOS EM MILHO COM O DELINEAMENTO III E MARCADORES MOLECULARES
}

\section{ADELMO RESENDE DA SILVA}

Tese apresentada à Escola Superior de Agricultura

"Luiz de Queiroz", Universidade de São Paulo, para a obtenção do título de Doutor em Agronomia, Área de Concentração: Genética e Melhoramento de Plantas.

PIRACICABA

Estado de São Paulo - Brasil

Março - 2002 


\title{
ANÁLISE GENÉTICA DE CARACTERES QUANTITATIVOS EM MILHO COM O DELINEAMENTO III E MARCADORES MOLECULARES
}

\author{
ADELMO RESENDE DA SILVA \\ Engenheiro Agrônomo
}

Orientador: Prof. Dr. CLÁUDIO LOPES DE SOUZA JÚNIOR

\begin{abstract}
Tese apresentada à Escola Superior de Agricultura "Luiz de Queiroz”, Universidade de São Paulo, para a obtenção do título de Doutor em Agronomia, Área de Concentração: Genética e Melhoramento de Plantas.
\end{abstract}

\author{
PIRACICABA \\ Estado de São Paulo - Brasil \\ Março - 2002
}


Dados Internacionais de Catalogação na Publicação (CIP) DIVISÃO DE BIBLIOTECA E DOCUMENTAÇÃO - ESALQ/USP

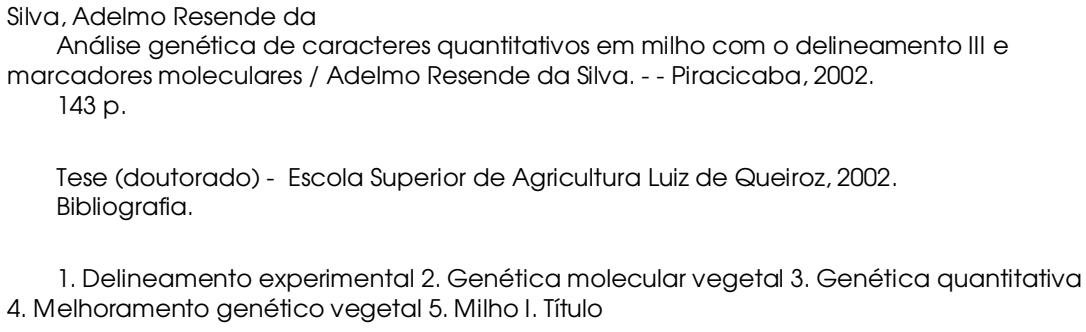

CDD 633.15

"Permitida a cópia total ou parcial deste documento, desde que citada a fonte - $\mathrm{O}$ autor" 


\title{
ESTE TRABALHO É DEDICADO:
}

\begin{abstract}
À minha noiva Anamaria, que se constituiu, a partir do nosso primeiro momento, em síntese de todo o meu amor e de todas as minhas razões;
\end{abstract}

Aos meus pais, Alaor e Joana Dar'C, meus irmãos, Ademar e Maria Luiza, meus cunhados Carlos e Lilian Mara, meus sobrinhos Bruno Eduardo e Marco Antônio, pelo apoio e presença constante, apesar da distância física;

Aos meus avós Antônio e Luiza, eternos em nossa memória, inimitáveis em seu amor conjugal e familiar.

Ao Professor Warwick Estevam Kerr, por ter me dado acesso à vida científica e pelos exemplos sublimados de amor à Deus, à pátria, à família e à genética. 


\section{AGRADECIMENTOS}

A Deus, inteligência suprema e causa primeira de todas as coisas, por ter concedido a oportunidade e as condições de perscrutar uma pequena parte de sua infinita criação, e de trabalharmos em nosso próprio progresso espiritual.

Ao Prof. Dr. Cláudio Lopes de Souza Jr. pela esmerada orientação e pelo apoio durante todo o período de desenvolvimento deste trabalho.

À Profa. Dra. Anete Pereira de Souza pela prestimosa co-orientação e pelas condições oferecidas para a realização das análises laboratoriais.

Ao colega Alexander Chávez Cabrera pela amizade sincera e desprendida e pelo apoio decisivo em muitos momentos importantes.

Aos colegas Sérgio Tadeu Sibov, Aurélio Mendes Aguiar e Alexandre Franco Garcia, pelo espírito de equipe, companheirismo e inestimável auxílio em todas as fases deste trabalho.

Aos colegas Rogério de Melo Costa Pinto, Rhainer Gleico Cardoso, Juan Carlos Pérez Velásques, José Ubirajara Moreira, Mateus Figueiredo Santos e Nelson Orasmo Filho, aos funcionários Antônio Jucelino Desidério e Ariberto Soares de Oliveira, e ao técnico bolsista Tiago de Moura Romani, pela valiosa ajuda na condução e na coleta de dados dos ensaios experimentais.

Aos colegas do Laboratório de Análises Genéticas e Moleculares do CBMEG/UNICAMP e do curso de pós-graduação em Genética e Melhoramento de Plantas da ESALQ/USP, pelos momentos de convívio e crescimento compartilhados.

A todos os professores e funcionários de Departamento de Genética da Escola Superior de Agricultura "Luiz de Queiroz" da Universidade de São Paulo, pelos ensinamentos transmitidos durante todo o desenvolvimento desta tese.

A todas as pessoas que direta ou indiretamente contribuíram para a realização do presente trabalho.

À FAPESP pela concessão da bolsa de estudos. 


\section{SUMÁRIO}

\begin{tabular}{|c|c|c|}
\hline & & Página \\
\hline RESUM & & vi \\
\hline SUMMA & ARY & ix \\
\hline 1 & 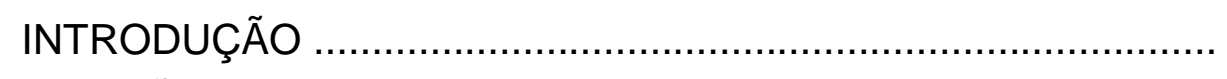 & 1 \\
\hline 2 & REVISÃO DE LITERATURA... & 3 \\
\hline 2.1 & Marcadores moleculares..... & 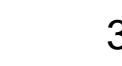 \\
\hline 2.1 .2 & Marcador molecular do tipo microssatélite.... & 5 \\
\hline 2.1.2.1 & Obtenção de microssatélites................... & 8 \\
\hline 2.2 & Mapas de ligação e detecção de QTLs.. & 9 \\
\hline 2.2 .1 & Delineamento genético experimental....... & 10 \\
\hline 2.2 .2 & Mapa genético utilizando marcadores moleculares... & 13 \\
\hline 2.2 .3 & 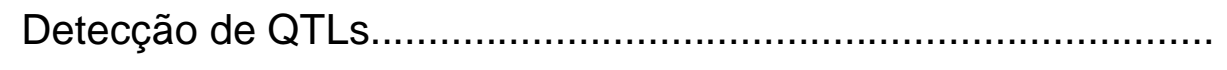 & 16 \\
\hline 2.2.3.1 & Estimativas de efeitos aditivos e dominantes de QTLs......... & 21 \\
\hline 2.3 & 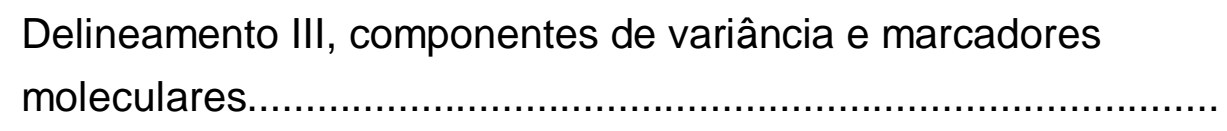 & 23 \\
\hline 2.3.1 & Componentes de variância....... & 24 \\
\hline 2.3.2 & 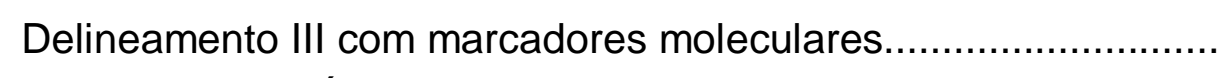 & 32 \\
\hline 3 & MATERIAL E MÉTODOS................... & 42 \\
\hline 3.1 & Material genético.............. & 42 \\
\hline 3.2 & Métodos.............................. & 43 \\
\hline 3.2.1 & Marcadores moleculares.................................... & 43 \\
\hline 3.2.1.1 & Extração e quantificação do DNA genômico...... & 43 \\
\hline 3.2.1.2 & Condições de amplificação e genotipagem........... & 44 \\
\hline 3.2.1.4 & Construção do mapa genotípico... & 44 \\
\hline 3.2 .2 & 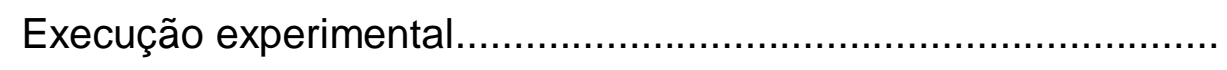 & 46 \\
\hline 3.2.2.1 & Estabelecimento dos experimentos... & 46 \\
\hline 3.2.2.2 & Caracteres avaliados e analisados..... & 47 \\
\hline
\end{tabular}


3.3 Análises estatísticas............................................................ 48

3.3.1 Modelos matemáticos............................................................... 49

3.3.2 Estimativas dos parâmetros genéticos........................................ 52

3.3.3 Análises de covariância e estimativas dos coeficientes de 53 correlação

3.3.4 Precisão das estimativas dos parâmetros genéticos..................... 55

3.3.5 Análise dos marcadores moleculares usando o delineamento III.. 57

3.3.5.1 Contrastes ........................................................................ 57

3.3.5.2 Análises de variância individuais para cada marcador ................ 58

$4 \quad$ RESULTADOS E DISCUSSÃO................................................. 62

4.1 Análise geral dos resultados........................................................ 62

4.1.1 Análises de variância............................................................. 65

4.2 Componentes de variância e correlações entre caracteres............ 66

4.2.1 Componentes de variância....................................................... 66

4.2.1.1 Produção de grãos................................................................. 66

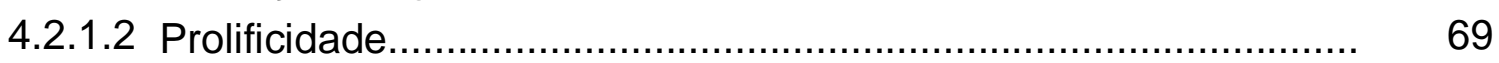

4.2.1.3 Altura da planta, da espiga e posição relativa da espiga............... 69

4.2.1.4 Florescimento feminino, masculino e intervalo de florescimento... 71

4.2.1.5 Número de folhas................................................................... 72

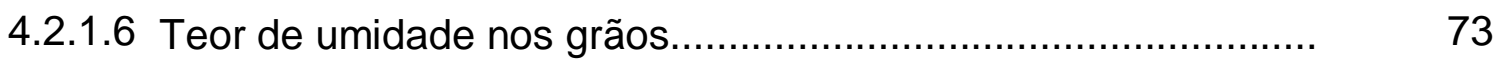

4.2.2 Correlações entre caracteres................................................

4.3 Análises dos marcadores utilizando o delineamento III............... 78

4.3.1 Produção de grãos.............................................................

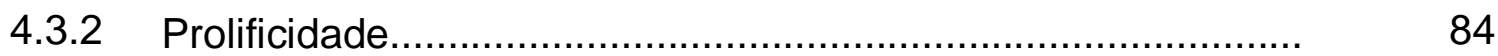

4.3.3 Altura da planta, da espiga e posição relativa da espiga............ 86

4.3.4 Florescimento feminino, masculino e intervalo de florescimento.. $\quad 91$

4.3.5 Número de folhas................................................................ 94

4.3.6 Teor de umidade nos grãos ...................................................... 96

$4.4 \quad$ Considerações finais................................................................... 98

$5 \quad$ CONCLUSÕES............................................................... 102

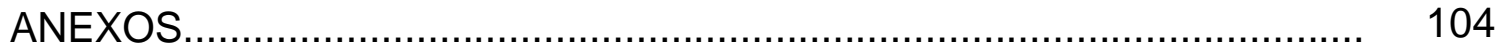

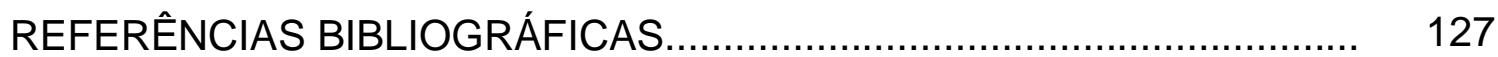

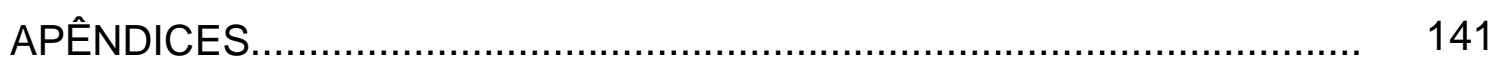




\title{
ANÁLISE GENÉTICA DE CARACTERES QUANTITATIVOS EM MILHO COM O DELINEAMENTO III E MARCADORES MOLECULARES
}

\author{
Autor: ADELMO RESENDE DA SILVA \\ Orientador: Prof. Dr. CLÁUDIO LOPES DE SOUZA JÚNIOR
}

\section{RESUMO}

Caracteres importantes em espécies vegetais estão, em sua maior parte, sob o controle de vários locos gênicos, denominados locos de caracteres quantitativos (QTLs). A expressão fenotípica desses caracteres produz uma distribuição contínua de valores devido à segregação genotípica, aos efeitos ambientais e à interação genótipos por ambientes. Com o advento dos marcadores moleculares e de modelos estatístico-genéticos adequados tornouse possível a detecção e o mapeamento de regiões cromossômicas que controlam estes caracteres. Este trabalho foi realizado para analisar caracteres quantitativos em uma população de milho tropical com os objetivos: (1) obter estimativas das variâncias genéticas aditiva e de dominância, e do grau médio de dominância; (2) construção de um mapa genético utilizando marcador molecular do tipo microssatélite; (3) detecção de QTLs e estimação de seus efeitos genéticos, e de suas interações com ambientes, utilizando o delineamento III. Neste trabalho foram utilizadas 250 progênies $F_{2: 3}$ retrocruzadas para ambos os genitores, totalizando 500 progênies, que foram avaliadas em seis ambientes para a obtenção de dados fenotípicos. Foi realizada a genotipagem com 140 marcadores moleculares para as 250 plantas $F_{2}$ genitoras. $O$ mapa genético foi construído utilizando 0 programa MAPMAKER/EXP V.3.0. Os componentes das variâncias genéticas e o grau de dominância dos caracteres foram estimados utilizando-se o delineamento III. A 
detecção de QTLs e as estimativas de seus efeitos genéticos foram efetuados utilizando a metodologia de Cockerham \& Zeng (1996). Os resultados das análises de variâncias evidenciaram sobredominância para produção de grãos e dominância parcial para os outros nove caracteres. Por causa do desequilíbrio de ligação nesta população, estas estimativas estão, provavelmente, superestimadas. O mapa genético com 140 marcadores tem 1.730,1 centiMorgans (cM) de extensão e intervalo médio de 12,4 cM entre marcadores adjacentes. Foram detectados QTLs em todos os cromossomos para todos os caracteres, indicando que os locos que controlam estes caracteres estão distribuídos pelo genoma. A análise genética utilizada permitiu a estimação dos efeitos aditivos, dominantes e epistáticos dos QTLs. Efeitos aditivos, dominantes e epistáticos foram detectados para todos os caracteres. As magnitudes, em módulo, dos efeitos aditivos e dominantes foram maiores do que os efeitos epistáticos para todos os caracteres, exceto para posição relativa da espiga onde os efeitos epistáticos foram um pouco maiores do que os efeitos dominantes. A porcentagem de marcadores que detectaram efeitos epistáticos variou de $10,71 \%$ para teor de umidade nos grãos a $50,71 \%$ para número de folhas. Para produção de grãos, os efeitos epistáticos foram detectados em $32,14 \%$ dos marcadores, sendo encontrados valores altos para alguns marcadores. Os efeitos dos QTLs detectados variaram muito em magnitude e sinal entre marcadores adjacentes, demonstrando que os QTLs contribuem de forma diferenciada para as expressões dos caracteres. Os efeitos dos QTLS tiveram pequena ou nenhuma interação genótipos por ambientes para os caracteres avaliados, exceto para teor de umidade nos grãos. 


\title{
GENETIC ANALISYS OF QUANTITATIVE TRAITS IN MAIZE BY USING THE DESIGN III AND MOLECULARS MARKERS
}

\author{
Author: ADELMO RESENDE DA SILVA \\ Adviser: Prof. Dr. CLÁUDIO LOPES DE SOUZA JÚNIOR
}

\section{SUMMARY}

Most of the agronomic traits in crop species are under the control of unknown number of loci, which have been termed quantitative trait loci (QTL). Because of genotypic segregation, environmental effects, and of genotype by environment interaction, the phenotypic values of these traits present continuous variation. The advent of molecular markers, and of sophisticated statisticalgenetic models allowed the analysis of quantitative traits at the DNA level, by detecting and mapping chromosomal regions with loci affecting those traits. This research was carried out to analyze quantitative traits in a tropical maize population by (1) estimating genetic parameters as additive and dominance genetic variance, and the level of dominance; (2) developing a genetic map with microsatellites as molecular markers; (3) detecting and estimating genetic effects of QTLs as well as QTLs by environment interaction by using the Design III methodology. The genetic material was a set of $250 \mathrm{~F}_{2: 3}$ progenies developed from a cross of two inbred lines. The $F_{2}$ plants, parents of the $F_{2: 3}$ progenies, were genotyped with microsatellites and a genetic map was developed by using MAPMAKER/EXP V.3.0 software. The $\mathrm{F}_{2:} 3$ progenies were backcrossed to both parental inbred lines giving rise to 500 backcrossed progenies, which were evaluated in six environments. The components of genetic variances and the 
level of dominance of the traits were estimated by using the Design III approach. The detection of QTLs and estimates of their genetic effects were computed by using Cockerham \& Zeng (1996) methodology. Average level of dominance was overdominance for grain yield (GY), and partial dominance for the other nine traits. Because of the linkage disequilibrium in this population, probably these estimates are overestimated. The genetic map with 140 markers spanned $1,730.1$ centimorgans (cM) in length with an average interval of $12.4 \mathrm{cM}$ between adjacent markers. QTLs were detected at all chromosomes for all traits, indicating that the genes controlling the quantitative traits assessed are spread in the genome. The genetic analysis used allowed the estimation of additive, dominance and epistatic effects of the QTLs. Additive, dominance and epistatic effects were detected for all traits, although the magnitudes, in module, of additive and dominance effects were larger than epistatic effects for all traits, except for ear placement where epistatic effects were slightly larger than dominance effects. The percentage of markers that detected significant epistatic effects ranged from $10.71 \%$ for grain moisture to $50.71 \%$ for number of leaves. For GY, the dominance effects were more important than additive effects; epistatic effects were detected in $32.14 \%$ of the markers, whereas in some markers high values were found. The magnitudes and signs of the QTLs effects were highly variable among the markers, showing that the contribution of the QTLs for the expression of the traits was very different, and that epistatic effects are important for the expression of all traits. Also, fewer QTL effects by environment interactions were detected for all traits, except for grain moisture. 


\section{INTRODUÇÃO}

No milho (Zea mays L.), e em outras espécies cultivadas, os principais caracteres são controlados por diversos locos, podendo existir diversos alelos por loco, sendo que o ambiente afeta a expressão fenotípica destes alelos. Devido à segregação genotípica, aos efeitos ambientais e à interação genótipos por ambientes, estes caracteres apresentam distribuição normal de seus valores fenotípicos. Por se tratar de caracteres mensurados por quantidades, estes são denominados de caracteres quantitativos (Allard, 1960; Stuber et al., 1987).

As técnicas utilizadas para o estudo destes caracteres, como médias, variâncias e covariâncias, têm sido baseadas em modelos genéticos que consideram a soma dos efeitos de todos os locos segregantes da população sob investigação (Falconer \& Makay, 1996). Com a recente incorporação de marcadores moleculares para a investigação destes caracteres, tornou-se possível monitorar regiões cromossômicas específicas que afetam sua expressão, isto é, que contêm loco ou locos que controlam caracteres quantitativos (Austin et al., 2000; Edwards et al., 1987; Stuber et al., 1992).

Os primeiros estudos identificando associações entre a variação de locos de marcadores moleculares e QTLs foram feitos com isoenzimas (Edwards et al., 1987; Stuber et al., 1987). Posteriormente, marcadores RFLP (Restriction Fragment Lenght Polymorfhism) tornaram-se os mais utilizados na construção de mapas genéticos e nas análises de QTLs, pois possibilitavam uma grande saturação de marcadores pelo genoma (Helentjaris et al., 1986; Tanksley, 1993; Paterson et al., 1991). Com o desenvolvimento da reação de polimerização em cadeia do DNA (PCR - Polymerase Chain Reaction - Saiki et al., 1985), surgiu uma segunda geração de marcadores moleculares e, dentre eles, os marcadores moleculares do tipo microssatélites são os de mais fácil uso e mais eficientes para a construção de mapas genéticos (Chin et al., 1996). 
A detecção de locos para caracteres quantitativos (QTLs) é um dos primeiros passos para a identificação dos genes que participam do controle de um caráter quantitativo. Para que esta detecção seja feita eficientemente, é necessário a construção de um mapa genético com bom nível de saturação de marcadores moleculares, de dados de caracteres oriundos de delineamentos genéticos adequados e com boa precisão experimental, além de um modelo estatístico-genético apropriado (Prioul et al., 1997; Lynch \& Walsh, 1998).

O delineamento III (Comstock \& Robinson, 1952) foi proposto para a obtenção de estimativas do grau médio de dominância dos locos que controlam caracteres quantitativos. Recentemente, Cockerham \& Zeng (1996) propuseram a utilização deste delineamento para a análise estatística-genética de marcadores moleculares. Esta metodologia é importante por permitir quantificar os efeitos aditivos, de dominância e de epistasia de cada loco e, consequentemente, identificar a importância dos seus efeitos para cada marcador.

Haja vista a existência de poucas pesquisas visando a estimação do grau de dominância e a detecção de QTLs de caracteres quantitativos de importância agronômica e/ou econômica em milho de origem tropical, os objetivos desta pesquisa foram: (1) obter estimativas das variâncias genéticas aditiva e de dominância, e do grau médio de dominância, utilizando o delineamento III de Comstock \& Robinson (1952); (2) construção de um mapa genético utilizando marcador molecular do tipo microssatélites; (3) detecção de QTLs e estimação de seus efeitos genéticos, e de suas interações com ambientes, utilizando o delineamento III de Cockerham \& Zeng (1996). 


\section{REVISÃO DE LITERATURA}

\subsection{Marcadores moleculares}

Sakiyama (1993) relata que o termo marcador tem sido utilizado para designar fatores morfológicos, fisiológicos, bioquímicos ou genéticos passíveis de serem identificados e que permitem o estudo comparativo de genótipos e de suas progênies. Os primeiros marcadores "modernos" foram as isoenzimas, seguidas cronologicamente pelo RFLP (Botsteisn et al., 1980; Grodzicker et al., 1974; Solomon \& Bodmer, 1979), pelo RAPD (Willians et al., 1990), por microssatélites (Litt \& Luty, 1989; Tautz, 1989; Weber \& May 1989), e pelo AFLP (Vos et al., 1995). Esses são os marcadores mais usados atualmente. Todos esses tipos de marcadores possuem grande potencial para estudos genéticos básicos e ou aplicados, respeitando-se as limitações de cada um. Dentre esses estudos podem ser citados evolução, variabilidade genética, caracterização de germoplasma (proteção de cultivares, pureza genética, monitoramento de fecundação cruzada, entre outros), seleção assistida por marcadores e mapeamento genético.

Geldermann (1975) propôs o termo locos controladores de caracteres quantitativos, de sigla QTL, que é a abreviatura da língua inglesa de quantitative trait locus (singular) ou loci (plural), o qual vem sendo adotado principalmente em estudos de mapeamento. Normalmente, não é possível determinar se o efeito detectado com o marcador é devido a um ou mais genes ligados que afetam o caráter. Por esta razão, o termo loco de caráter quantitativo (QTL) é usado para descrever a região do cromossomo que possui um ou mais genes influenciando na manifestação fenotípica desse caráter (Bearzoti, 2000).

Com marcadores adequados disponíveis e distribuídos por todo o genoma, é possível avaliar todas as regiões cromossômicas quanto aos seus 
efeitos na manifestação de caracteres quantitativos (Stuber et al., 1987). O uso de marcadores moleculares para identificar QTLs que controlam caracteres quantitativos tornou-se um procedimento padrão em genética vegetal, tanto para a compreensão de suas bases genéticas quanto em programas de melhoramento (Beckmann \& Soller, 1986; Stuber et al., 1992). Para que os QTLs possam ser localizados e seus efeitos estimados, há necessidade do mapeamento do genoma e da determinação do quanto cada uma destas regiões contribuem para o caráter (Paterson et al., 1991).

Um marcador ideal deve ser polimórfico entre os parentais e apresentar segregação mendeliana para essa população. Por exemplo, a segregação observada dos genótipos dos marcadores para uma população $F_{2}$, considerando um loco com dois alelos (b e B), não deve ser significativamente diferente da segregação esperada de 1:2:1 para os genótipos bb, Bb e BB, respectivamente. Além desses, outros aspectos também são importantes tais como custo por unidade de genotipagem, neutralidade fenotípica e abundância dos marcadores moleculares no genoma (Tanksley, 1993). O sucesso de qualquer tecnologia de marcador é dependente da disponibilidade de um grande número de marcadores altamente polimórficos, de uma estreita relação de ligação entre o loco marcador e o caráter de interesse (Dudley, 1993) e da facilidade com que os marcadores podem ser utilizados (Senior et al., 1996).

O marcador molecular microssatélite possui as vantagens de ser altamente reprodutível, apresentar apenas um loco e herança Mendeliana, ser abundante, ser codominante, ter distribuição casualizada por todo o genoma e possuir um bom nível de polimorfismo. Dados genotípicos de microssatélites têm o potencial de constituir um perfil alélico único, ou DNA fingerprinting, para o estabelecimento de uma identidade individual. Por ser baseado em uma reação altamente específica de $P C R$ (Polymerase Chain Reaction), não usar radioatividade, requerer pequena quantidade de DNA em suas reações e não necessitar de qualquer transferência física de material genético (sondas) entre laboratórios, os microssatélites simplificam e padronizam as análises genéticas (Chin et al., 1996; Powell et al., 1996). 


\subsubsection{Marcador molecular do tipo microssatélite}

Microssatélite (Litt \& Luty, 1989; Tautz, 1989; Weber \& May, 1989) é um tipo de marcador molecular constituído basicamente de segmentos curtos de DNA (motivos) que se repetem sucessivamente, ladeadas por seqüências únicas no genoma. Ele está presente, virtualmente, em todos os seres vivos. São conhecidos por outros nomes tais como SSR - simple sequence repeats (Litt \& Luty, 1989; Weber \& May, 1989), STR - short tandem repeats (Edwards et al., 1991), short tandem DNA repeats (Litt \& Luty, 1989), STMS - sequencetagged microsatellite site (Beckmann \& Soller, 1990), SSLP - simple sequence lenght polymorphism (Tautz, 1989).

Os microssatélites são constituídos por motivos que possuem de 1 a 6 pares de bases (pb). Esses motivos são repetidos de 5 a 50 vezes, sendo que, em alguns casos, podem chegar a centenas de vezes (Chin et al., 1996; Karp et al., 1996; Langercrantz et al., 1993; Morgante et al., 1994; Senior et al., 1996; Thomas \& Scott, 1993).

Esses motivos repetidos são flanqueados por seqüências supostamente únicas no genoma e conservadas (mesmo loco) entre indivíduos da mesma espécie e até entre espécies relacionadas (Lübberstedt et al., 1997). Essas seqüências únicas servem como molde para a síntese de oligonucleotídeos (primers) de microssatélites, os quais permitirão a amplificação do segmento de DNA que possui esses motivos repetidos, ou seja, a amplificação do loco único de microssatélite. Esses oligonucleotídeos são pequenas seqüências de bases de DNA, normalmente variando de 18 a 30 , que servem como molde inicial para a extensão do fragmento de DNA pela enzima DNA polimerase na reação de PCR. Apesar de serem pequenos em números absolutos, os primers são relativamente grandes para a reação de PCR, o que permite a realização de uma reação de amplificação altamente específica. Essa especificidade é obtida através do aumento da temperatura de anelamento, do primer com o DNA "alvo", favorecendo apenas as amplificações de segmentos de DNA que realmente contenham o loco de microssatélite, e evitando o pareamento não específico dos primers, ou seja, a amplificação errada de um segmento de DNA. 
Senior \& Heun (1993) estudaram a presença e a herança de microssatélites em milho. Os autores mostraram que microssatélites para esta espécie apresenta polimorfismo semelhante ao encontrado para o marcador RFLP. Para um pequeno grupo formado por nove linhagens endogâmicas de milho Chin et al. (1996) observaram uma relativa abundância de diferentes motivos. Os autores identificaram que as três classes mais abundantes de microssatélites foram $(A G)_{n},(C C T)_{n}$ e $(C C G)_{n}$, dentre as 576 seqüências de microssatélites examinadas.

O polimorfismo dos locos microssatélites é detectado pela diferença no tamanho dos fragmentos amplificados e estes variam de acordo com o número de motivos repetidos que possuem (Tautz, 1989). Os locos de microssatélites possuem uma natureza altamente mutável, o que aumenta a possibilidade de se ter muitas variantes alélicas em cada loco. Mais de 30 diferentes alelos foram reportados em algumas situações (Karp et al., 1996).

A hipervariabilidade observada de microssatélites ainda não é totalmente compreendida, mas sugere-se que sua origem esteja associada à ocorrência de crossing-overs desiguais ou por erros durante a replicação do DNA, em um processo conhecido como slippage. Durante a replicação do DNA a molécula (fita) que está sendo sintetizada, logo após ser replicada, pareia-se com a molécula molde. Mas, se esse pareamento da fita recém-sintetizada for feito com uma unidade da repetição (motivo) errada na fita molde, pode fazer com que a enzima DNA polimerase se posicione erradamente, comprometendo a replicação do restante da fita de DNA. Nesse caso, a fita sintetizada terá uma variação do número de cópias da unidade de repetição, ou seja, variação do número de motivos. Se esse processo acontecer na formação de gametas, essa nova fita constituirá em um novo alelo (Levinson \& Gutman, 1987; Tautz et al., 1986).

Visto que a geração de mutações é essencialmente um processo neutro, pode-se esperar que os microssatélites sejam encontrados distribuídos ao acaso por toda a porção eucromática do genoma (Chin et al., 1996). Realmente, mapas detalhados de vários organismos eucarióticos mostram que estas seqüências repetidas são distribuídas ao acaso e uniformemente por todo o genoma (Barendse et al., 1994; Chin et al., 1996). Entretanto, Ogliari (1999) relata que quanto à distribuição dos microssatélites pelos genomas vegetais, a 
freqüência de ocorrência, e a própria forma de distribuição, são amplamente variáveis. A distribuição de microssatélites através do genoma de milho parece ocorrer de forma casual (Senior et al., 1996; Taramino \& Tingey, 1996).

Em eucariotos, pode-se esperar encontrar no mínimo um microssatélite a cada 10 mil pares de bases (pb). Eles têm sido correlacionados com regiões de alta divergência em uma escala de tempo evolucionária (Hancock \& Dover, 1988; Tautz et al., 1986). Condit \& Hubbel (1991) estimaram, para milho e cinco espécies perenes tropicais, um total de $10^{4}$ a $10^{5}$ microssatélites (com repetições $(A C)_{n}$ ou $(A G)_{n}$ ) por genoma vegetal. Para o milho, a freqüência média é de um loco a cada 50 mil pb (Chin et al., 1996; Morgante \& Olivieri, 1993).

Para a reação de amplificação (PCR) são necessários apenas 50 a 100 ng de DNA de qualquer tecido da planta. O comprimento do fragmento de DNA amplificado normalmente estará dentro de 50 a 300 pares de bases (pb), podendo chegar a $500 \mathrm{pb}$ em alguns casos, o que permite ter resolução dos produtos amplificados em um gel padrão de seqüenciamento, mesmo se a diferença for de apenas um nucleotídeo (Tautz, 1989). Os microssatélites são codominantes, ou seja, todos os alelos presentes no indivíduo são amplificados.

Em comparação com as técnicas que envolvem hibridação de DNA, as de PCR, tal como é feito para microssatélites, geralmente são de custo menor, menos laborosas, mais fáceis de implementar na rotina de programas de melhoramento e de menor tempo para a obtenção dos resultados (Epplen et al., 1992; Milach, 1998). Eles permitem, virtualmente, a utilização de qualquer população segregante para estudos de ligação. Consequentemente, marcadores microssatélites têm sido propostos como uma das melhores opções para mapeamento genético, pois fornecem mapas saturados de forma relativamente barata e não muito laborosa (Beckmann \& Soller, 1990; Chin et al., 1996; Milach, 1998).

Atualmente, muitas espécies já possuem um conjunto de microssatélites disponível para utilização em estudos genéticos. Entre estas estão soja (Akkaya et al., 1992), milho (Davis et al., 1999; Senior \& Heun, 1993; Taramino \& Tingey, 1996), trigo (Röder et al., 1995), arroz (Wu \& Tanksley, 1993), melancia (Jarret et al., 1997), maçã (Guilford et al., 1997), cevada (Becker \& Heun, 1995) e sorgo (Taramino et al., 1997). Excetuando-se o milho, o arroz, a soja e o trigo, 
o número de microssatélites desenvolvidos até o momento para as outras espécies é ainda pequeno e seu emprego tem sido limitado ao estudo da divergência genética, estando sempre associado a outros marcadores. Este fato deve-se justamente ao elevado custo de desenvolvimento deles, sendo, no momento, justificável apenas para culturas de grande importância econômica (Souza, 2001).

\subsubsection{Obtenção de microssatélites}

O desenvolvimento de microssatélites para uma espécie envolve 0 conhecimento das seqüências únicas adjacentes à região contendo os motivos repetidos. Estas seqüências podem ser obtidas inicialmente, embora em pequeno número e apenas para algumas espécies, através de buscas em bancos de dados pela internet. Entretanto, a obtenção de um conjunto completo de microssatélites para uma espécie somente é possível através de um programa de desenvolvimento de microssatélites. Esse programa consiste, em linhas gerais, na construção de uma biblioteca genômica enriquecida em clones que podem gerar microssatélites. Esse enriquecimento é efetuado através de uma seleção prévia quanto à presença, nos fragmentos clonados, de repetições em tandem (motivos adjacentes). Em etapas posteriores, os clones que possuem repetições próprias dos microssatélites são identificados e sequenciados. O desenvolvimento de um programa como esse é a principal limitação para a aplicação de microssatélites devido à necessidade de investimentos altos e infra-estrutura especializada de laboratório (Chin et al., 1996; Souza, 2001).

Um importante conceito para o mapeamento genético diz respeito ao polimorfismo. Polimorfismo refere-se à presença de mais de uma forma alélica, sendo que sua detecção pode ser feita fenotipicamente, por meio de um marcador morfológico, ou genotipicamente, por meio de marcadores moleculares. Segundo Souza (2001), o polimorfismo é caracterizado quando, pelo menos, um por cento dos alelos são diferentes.

Uma vez detectados os clones desejados, eles devem ser seqüenciados e a região contendo a seqüência única é utilizada para a construção dos 
oligonucleotídeos a serem empregados na amplificação desse loco em diferentes genótipos. Visando à facilitação da etapa de detecção do polimorfismo, os oligonucleotídeos são sintetizados, sempre que possível, de forma que o produto de amplificação tenha no máximo $250 \mathrm{pb}$. Em seguida, o par de oligonucleotídeos é utilizado para amplificação do loco, a partir do DNA genômico de diferentes indivíduos. Esse procedimento é feito para a identificação e caracterização dos alelos do microssatélite entre diferentes genótipos (Chin et al., 1996; Souza, 2001).

Até janeiro de 2002 já foram publicadas as sequências de 1735 pares de primers para microssatélites de milho na página da internet http://www.agron.missouri.edu/. Esta base de dados é pública e tem se expandido rapidamente, aumentando o número de locos de microssatélites e possibilitando o acesso público aos progressos obtidos.

\subsection{Mapas de ligação e detecção de QTLs}

Caracteres importantes em espécies vegetais estão, em sua maior parte, sob controle de muitos locos. Estes caracteres têm sido denominados como poligênicos ou quantitativos, e apresentam variação contínua por causa da segregação genotípica, dos efeitos ambientais e da interação genótipos por ambientes (Allard, 1960). Pesquisas de caracteres quantitativos inicialmente foram baseados em modelos que consideraram a soma dos efeitos de todos os locos segregando independentemente (Kempthorne, 1957; Falconer \& Mackay, 1996; Mather \& Jinks, 1982). Com o advento dos marcadores moleculares tornou-se possível monitorar locos ou conjunto de locos que contribuem para o caráter quantitativo (Edwards et al., 1987; Keim et al., 1990; Lander \& Botstein, 1989; Stuber et al., 1987).

Thoday (1961) e Mather \& Jinks (1982) apresentaram a teoria para a interpretação da ligação entre um loco marcador e um loco de caráter quantitativo (QTL). Entretanto, ainda existia a impossibilidade da construção de mapas genéticos consistentes, devido à falta de locos com marcadores genéticos adequados, pouco espaçados no genoma e em quantidade suficiente (Edwards et al., 1987). Esse problema foi resolvido com o desenvolvimento dos 
marcadores moleculares. A construção de mapas genéticos com maior número de marcadores, por sua vez, possibilitou o uso e o desenvolvimento de métodos estatísticos mais sofisticados de mapeamento, que permitem maior precisão na localização dos QTLs e a discriminação dos efeitos individuais dos mesmos. Então, várias contribuições a essa teoria seguiu-se ao advento dos marcadores moleculares (Cockerham \& Zeng, 1996; Cowen, 1988; Edwards et al., 1987; Geldermann, 1975; Jansen, 1993; Jensen, 1989; Jiang \& Zeng, 1995; Knapp et al., 1990; Mackay, 2001; Soller et al., 1976; Soller \& Beckmann, 1983; Weller, 1986; Zeng, 1993, 1994; entre outros).

O primeiro mapa genético de milho, publicado por Emerson et al., $(1935)^{1}$, citado por Davis et al. (1999), continha 62 locos baseados em caracteres morfológicos. O primeiro mapa com marcadores moleculares em milho foi publicado por Helentjaris et al. (1986) e continha 116 locos RFLP, derivados de cDNA e de clones genômicos. Vários outros exemplos de publicações de mapas de ligação em milho podem ser encontrados, principalmente com RFLP (Ajmone-Marsan et al., 1994; Ajmone-Marsan et al., 2001; Beavis \& Grant, 1991; Burr et al., 1988; Byrne et al., 1996; Castiglione et al., 1999; Coe et al., 1987; Edwards et al., 1992; Lebreton et al., 1995; Lübberstedt et al., 1997; Veldboom et al., 1994; Vuylsteke et al., 1999). O mapa genético de milho já divulgado com maior saturação foi construído com 1736 locos, dos quais 1156 locos foram originados de cDNA, 545 locos de clones genômicos randômicos, 16 locos de microssatélites, 14 locos de isoenzimas e 5 locos de clones anônimos (Davis et al., 1999).

\subsubsection{Delineamento genético experimental}

Os delineamentos experimentais mais usuais para as espécies cultivadas baseiam-se no uso de populações segregantes, obtidas do cruzamento entre duas linhagens endogâmicas fenotipicamente divergentes para o caráter quantitativo em estudo. Os diversos tipos de delineamentos utilizados para a realização do mapeamento genético de espécies vegetais têm em comum o fato de gerar e maximizar o desequilíbrio de ligação para os locos segregantes.

1 EMERSON, R.A.; BEADLE, G.W.; FRASER, A.C. A summary of linkage studies in maize. Cornell Universitv Aaricultural ExpDerimental Station Memoir. v.180. o.1-83. 1935. 
Conforme salienta Tanksley (1993), o desequilíbrio de ligação pode ser decorrente de diversas causas, incluindo seleção e deriva genética, entretanto, a causa predominante em populações segregantes derivadas de cruzamentos entre linhagens, é a ligação física dos locos. O desequilíbrio de ligação, devido à ligação física dos locos, está no seu ponto máximo nas populações derivadas de cruzamentos controlados. Como conseqüência, a capacidade de se detectar a ligação entre dois locos fisicamente ligados está, também, em seu ponto máximo. Assim, os principais tipos de gerações segregantes (delineamentos) utilizados em mapeamento genético utilizam populações $F_{2}$, populações obtidas por retrocruzamentos, linhagens puras recombinantes ou linhagens duplohaplóides (Lynch \& Walsh, 1998; Tanksley, 1993).

Em uma população de plantas $F_{2}$ (ou delineamento $F_{2}$ ) o desequilíbrio de ligação atinge seu ponto máximo e, por isso, Young (1994) considera essa população como a opção mais indicada para a construção de mapas moleculares. Entretanto, o autor comenta que o maior problema da utilização dessas populações é sua condição temporária. Nessas populações, tanto a genotipagem quanto a avaliação dos caracteres quantitativos são efetuados para cada planta em separado, aumentando a variação experimental e diminuindo a precisão da deteç̧ão ou do mapeamento de QTLs. Essa limitação pode ser superada utilizando-se de delineamentos $F_{2: 3}$, onde as plantas $F_{2}$ são genotipadas enquanto o caráter associado ao genótipo individual é estimado pelo valor médio das progênies $F_{2: 3}$ (Lynch \& Wash, 1998). Também é possível a manutenção das progênies $F_{2: 3}$ através de polinizações controladas entre plantas da mesma progênie, perpetuando assim, a fonte de material vegetal para coleta de DNA, para avaliações experimentais ou para utilização dessas progênies no prosseguimento do programa de melhoramento genético daquela espécie.

Populações obtidas por retrocruzamentos são facilmente produzidas a partir de linhagens endogâmicas de diversas espécies, incluindo alógamas (milho) e autógamas (trigo). Entretanto, as mesmas limitações e a mesma alternativa apresentada para populações $\mathrm{F}_{2}$, quanto à condição temporária e à avaliação fenotípica, podem ser aplicadas nesse caso. Um exemplo de delineamento com retrocruzamento é o delineamento III (Comstock \& Robinson, 1952). Esse delineamento utiliza plantas $F_{2}$, originadas do cruzamento entre 
duas linhagens endogâmicas, retrocruzadas para ambas as linhagens parentais. Ao invés de usar plantas $F_{2}$ para os retrocruzamentos, pode-se usar as progênies $F_{2: 3}$ obtidas pela autofecundação de cada planta $F_{2}$, uma vez que o conjunto de gametas de cada progênie $F_{2: 3}$ representa os gametas da planta $F_{2}$ correspondente. Essa estratégia aumenta o número de sementes que podem ser obtidas de cada retrocruzamento, visto que a colheita de sementes será feita em várias plantas $F_{2: 3}$ ao invés de apenas uma planta $F_{2}$, aumentando também, o número de experimentos que podem ser realizados para a avaliação fenotípica dos caracteres quantitativos.

Linhagens recombinantes são produzidas pela autofecundação, por cinco ou mais gerações, de plantas de uma geração $F_{2}$. $O$ delineamento conhecido na literatura como de linhagens puras recombinantes, explora o desequilíbrio de ligação que permanece em um conjunto dessas linhagens. Tanksley (1993) cita que, nesse caso, o desequilíbrio de ligação é menor do que aquele encontrado nos delineamentos anteriores (retrocruzamentos e população $F_{2}$ ), o que diminui o poder de detecção de ligação entre os locos e o caráter quantitativo. Entretanto, Burr et al. (1988) consideram como vantagens de uma população de linhagens puras recombinantes: 1 - pode ser considerada permanente, uma vez que não há mais segregação, podendo ser usada indefinidamente para o mapeamento; 2 - toda a informação gerada é cumulativa, fazendo com que novos dados, genotípicos e/ou fenotípicos, possam ser integrados ao mapa existente; 3 - o número de sementes de cada genótipo deixa de ser limitante, podendo ser obtidas tantas sementes quantas forem necessárias para avaliações fenotípicas ou extração de DNA; 4 - maior possibilidade de recombinação devido às várias gerações de autofecundação a que as linhagens são submetidas, possibilitando a identificação de marcadores fortemente ligados aos caracteres fenotípicos.

Linhagens duplo-haplóides são obtidas pela cultura de anteras de plantas $F_{1}$. Nessa cultura de anteras é utilizado a substância colchicina, visando à duplicação do número de cromossomos de grãos de pólen. Plantas duplohaplóides são, então, obtidas de células com número duplicado de cromossomos. Essas plantas são consideradas como totalmente homozigotas, uma vez que seu genoma é constituído do conjunto haplóide de cromossomos duplicados. A autofecundação de plantas desse tipo dará origem a sementes 
com genótipos idênticos, isto é, linhagens duplo-haplóides. Esse delineamento reúne as vantagens do delineamento de linhagens puras recombinantes com o maior poder de detecção do delineamento de retrocruzamento. Em espécies em que este tipo de linhagens pode ser obtido, como cevada e várias espécies de brássicas, diversos mapas genéticos têm sido construídos (Coelho, 2000).

Em qualquer delineamento experimental o poder de detecção de um QTL será tanto maior quanto maior for o número de marcadores disponíveis e de indivíduos genotipados e avaliados para os caracteres quantitativos (Lander \& Botstein, 1989). Estudos teóricos iniciais sugeriram que uma população muito grande (acima de 1000 plantas) seria necessária para identificar associações entre marcadores e caracteres quantitativos (Soller \& Brody, 1976). Entretanto, resultados de experimentos iniciais mostraram que a detecção da segregação de QTLs nestas populações poderia ser acompanhada com progênies com número menor de plantas (Edwards et al., 1987; Stuber et al., 1987). A partir desses trabalhos iniciais e, principalmente, devido à grande quantidade de trabalho e recursos financeiros investidos nas avaliações fenotípica e genotípica de grandes populações, o número de plantas (progênies) avaliadas varia entre 100 e 300 na maioria dos trabalhos publicados envolvendo mapeamento de QTLs. Mas é certo que a amostra da população deve ter o maior tamanho possível dentro da capacidade de trabalho da equipe envolvida. As amostras com menos de 50 indivíduos muito provavelmente terão uma baixa resolução de mapeamento (Young, 1994).

\subsubsection{Mapa genético utilizando marcadores moleculares}

Um mapa genético é uma representação simplificada do genoma, onde a molécula de DNA de cada cromossomo é representada por marcas ordenadas e mais ou menos espaçadas. Para cada cromossomo é obtido um conjunto de marcas ligadas entre si. Esse conjunto é denominado de grupo de ligação. A ligação entre essas marcas baseia-se na hipótese de que a co-transmissão de dois marcadores reflete sua proximidade, uma vez que a probabilidade de ocorrer permutas genéticas entre dois marcadores é inversamente proporcional à proximidade física entre eles. Cada uma dessas marcas possui, então, um 
vínculo genético com a região cromossômica que ela representa. A determinação da ordem e da distância relativa entre as marcas (marcadores) de um mesmo grupo de ligação, constitui um dos principais objetivos do mapeamento genético.

Após a genotipagem da população que será utilizada para o mapeamento, os marcadores que possuem segregação mendeliana são analisados. Para a construção dos grupos de ligação, em geral, são considerados 2 marcadores de cada vez. São efetuados cálculos estatísticos para a detecção de recombinação entre esses marcadores, tomando-se por base sua segregação genotípica. Se os dois marcadores estiverem em cromossomos diferentes, então a probabilidade de ocorrência de gametas recombinantes entre eles será igual a 0,5 . Mas se os dois marcadores estiverem ligados em um mesmo cromossomo, então a recombinação dependerá da ocorrência do fenômeno da permuta genética (crossig-over) entre eles, por acasião da meiose. Na realidade, para que a recombinação se manifeste é preciso que ocorra um número ímpar de permutas entre os locos, pois se houver a ocorrência de um número par deses eventos, a configuração original é restaurada (Bearzoti, 2000).

Em seguida, pode-se usar a chamada propriedade transitiva: considerando três marcadores, $A, B$ e $C$, se $A$ está ligado a $B$, e B está ligado $C$, então $A$ está ligado a $C$. Dessa forma, os grupos vão sendo construídos (Bearzoti, 2000). Finalmente, a ordem correta dos marcadores dentro do grupo de ligação é realizada através de análise multiponto. Como houve um grande aumento do número de marcas utilizadas na construção dos mapas, também havendo um aumento no número de indivíduos genotipados, houve a necessidade do desenvolvimento de vários algoritmos e programas computacionais para a construção de mapas genéticos, como o MapMaker (Lander et al., 1987), o Gmendel (Liu \& Knapp, 1992) e o JoinMap (Stam, 1993).

O programa Mapmaker versão 3.0 (Lander et al., 1987; Lincoln et al., 1992) é relativamente simples de ser operado. Este programa realiza o mapeamento genético de marcadores moleculares. Ele possui recursos (comandos) que auxiliam na obtenção e na certificação de um mapa genético. Por exemplo, o comando group realiza testes de dois ou de três pontos entre 
todos os marcadores e agrupa, de acordo com o $L O D$ score e a freqüência máxima de recombinação sugeridos pelo usuário, todos aqueles que pertencem ao mesmo grupo de ligação. Um $L O D$ score igual a 2 significa que a hipótese dos marcadores estarem ligados é 100 vezes $\left(10^{2}\right)$ mais provável do que a hipótese deles não estarem ligados. Pelo comando compare são realizados testes de dois ou três pontos entre todos os marcadores de um determinado grupo de ligação para estabelecer a melhor ordem desses marcadores, de acordo com o LOD sugerido pelo usuário. Entretanto, esse comando faz todas as combinações possíveis considerando todos os marcadores, ou (n!)/2 combinações, requerendo um grande trabalho computacional, sendo que sua utilização só é possível, atualmente, para grupos de ligação que contenham menos de 11 marcadores. Para contornar esse problema, pode-se lançar mão do comando ripple, onde é definido pelo usuário um número máximo de marcadores que poderão ser incluídos nas combinações a serem feitas.

A distância entre os marcadores é obtida através da freqüência de recombinação, que é a probabilidade de ocorrência de permuta genética entre dois marcadores. Esta medida não é aditiva porque é provável que haja interferência, isto é, a ocorrência de uma permuta genética afeta a ocorrência de outras permutas em regiões adjacentes. A distância de mapeamento, que é expressa em centiMorgans (cM), é calculada com base na freqüência de recombinação através de funções de mapeamento. Estas predizem o número de crossing-overs a partir da freqüência de recombinação observada. A função de Haldane (1919) postula que o crossing-over ocorra casualmente e de forma independente ao longo do cromossomo, isto é, sem interferência. Kosambi (1944) propôs uma função alternativa na qual é considerada uma interferência moderada.

Não há uma relação universal entre distância de mapa e a distância física entre os locos. Dependendo da espécie estudada, a quantidade de DNA que corresponde a 1 centiMorgan (cM) varia amplamente. Além do mais, a taxa de recombinação está sob controle genético e alguns genes influenciam esta taxa ao longo de todo o genoma enquanto outros, têm ação em regiões específicas do cromossomo (Brooks, 1988). Este fato pode fazer com que a quantidade de DNA para cada $\mathrm{cM}$, até dentro de um mesmo cromossomo e, principalmente, próximo aos telômeros e centrômeros, sofra uma considerável 
variação. Para o genoma do milho é estimado que contenha $1400 \mathrm{cM}$ de extensão e que seja constituído de $3 \times 10^{9}$ pares de bases (pb). Dessa forma, um

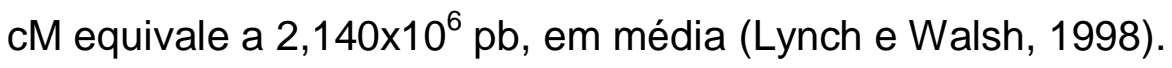

\subsubsection{Detecção de QTLs}

De acordo com Lynch \& Walsh (1998), a associação entre o marcador e - QTL pode ser avaliada utilizando-se um, dois ou mais marcadores simultaneamente. O método de análise onde um só marcador é utilizado consiste na comparação estatística do valor médio do caráter para as distintas classes genotípicas do marcador. Um resultado significativo denotaria a existência de ligação entre o marcador e um QTL do caráter em questão, embora os efeitos do QTL e a sua distância do marcador não possam ser estimados com precisão neste caso. Assim, cada teste de associação carátermarcador é realizado independente da informação dos outros locos marcadores. Para um cromossomo com $n$ marcas, $n$ testes são realizados.

Entretanto, Tanksley (1993) enumera como desvantagem do método de mapeamento por marcas simples o fato de que quanto maior a distância entre 0 QTL e o marcador, menor é a probabilidade de se detectá-lo estatisticamente, devido à possibilidade de recombinação entre o gene marcador e o QTL. Liu (1998) considerando esse fato, relata que esta análise não permite a estimação dos parâmetros genéticos do modelo conjunto (todos os marcadores) com a posição do loco em questão, acarretando uma subestimação da probabilidade de detecção do QTL. Lynch \& Walsh (1998) argumentam que não é possível a distinção entre um QTL de pequeno efeito, situado muito próximo ao marcador, de um QTL que apresenta grande efeito, mas situado mais distante do marcador. Esses autores também argumentam que não existe independência entre os testes de hipótese para a ligação, e que este fato não permite que se obtenha uma posição precisa do QTL, podendo haver imprecisão na estimativa do efeito do QTL e de sua posição. Mas estes problemas podem ser minimizados quando um número grande de marcadores segregantes é utilizado cobrindo todo o genoma (usualmente em intervalos menores que $15 \mathrm{cM}$ ). Sob 
estas condições, qualquer QTL potencial pode estar ligado fortemente a, pelo menos, um marcador genético (Tanksley, 1993).

A detecção de ligação genética entre marcadores e QTLs depende da existência de desequilíbrio de ligação entre os alelos do loco marcador e do QTL. Sem esse pré-requisito, os alelos dos locos marcadores e dos QTLs ocorrerão em combinações equivalentes à distribuição independente, fazendo com que os QTLs não sejam detectados. Este desequilíbrio cria associação entre o loco marcador e o QTL segregante. Vários delineamentos experimentais e metodologias estatísticas têm sido desenvolvidos para explorar este desequilíbrio como, por exemplo, populações $F_{2}$ (Falconer \& Mackay, 1996; Lynch \& Walsh, 1998).

Segundo Lynch \& Walsh (1998) o elemento básico sobre o qual a teoria formal de mapeamento de QTLs está fundamentada, é a probabilidade condicional de que o genótipo do QTL é $Q_{k}$, dado que o genótipo do marcador observado é $M_{\mathrm{j}}$. Então, pela definição de probabilidade condicional:

$$
\operatorname{Pr}\left(Q_{k} \mid M_{j}\right)=\frac{\operatorname{Pr}\left(Q_{k} M_{j}\right)}{\operatorname{Pr}\left(M_{j}\right)},
$$

em que: $\operatorname{Pr}\left(Q_{k} M_{j}\right)$ é a probabilidade conjunta de ocorrência do genótipo do QTL e do marcador (por exemplo, $\operatorname{Pr}\left(Q_{k} M_{j}\right)=\operatorname{Pr}(q M / q M$ ) é a probabilidade do genótipo qq do QTL ocorrer junto com o marcador MM na população); $\operatorname{Pr}\left(M_{j}\right)$ é a probabilidade marginal, isto é, é a probabilidade de ocorrência do genótipo do marcador (por exemplo, $\operatorname{Pr}\left(M_{j}\right)=\operatorname{Pr}(M M)$ é a probabilidade do genótipo MM do marcador ocorrer na população). Estas probabilidades, $\operatorname{Pr}\left(Q_{k} M_{j}\right)$ e $\operatorname{Pr}\left(M_{j}\right)$ são funções do delineamento experimental empregado para produzir as populações e do mapa de ligação.

Com base nesta probabilidade condicional, o valor do caráter para os vários genótipos marcadores pode ser calculado. Supondo que existam $n$ genótipos QTLs, onde a média do Q-ésimo genótipo do QTL é $\mu_{Q k}$, o valor médio para o genótipo do marcador $M_{j}$ é dado por:

$$
\mu_{M j}=\sum_{k=1}^{n} \mu_{Q k} \operatorname{Pr}\left(Q_{k} \mid M_{j}\right)
$$


O efeito do QTL é representado por $\mu_{\mathrm{Qk}}$ e a posição do QTL é representada através da probabilidade condicional $\operatorname{Pr}\left(Q_{k} \mid M_{j}\right)$. Esta equação é geral e pode ser utilizada com vários genótipos marcadores e vários QTLs.

O uso da probabilidade condicional permite o emprego de dois métodos para detectar e estimar os efeitos dos QTLs: 1 - método baseado em modelos lineares; 2 - método baseado no modelo de máxima verossimilhança.

O método baseado em modelos lineares mais simples, segundo Lynch \& Walsh (1998), considera o valor fenotípico $z_{i k}$ do $k$-ésimo indivíduo de genótipo marcador i, como resultante da soma de um valor médio $\mu$, com um efeito de marcador $b_{i}$ e o efeito de erro $e_{i k}$, isto é:

$$
z_{\mathrm{ik}}=\mu+b_{\mathrm{i}}+\mathrm{e}_{\mathrm{ik}}
$$

Este é o modelo da análise de variância, sendo que a presença da ligação com um QTL é indicada pelo efeito significativo do marcador. Pode-se expressar este modelo como regressão múltipla com o valor fenotípico para o indivíduo $j$ dado por:

$$
z_{j}=\mu+\sum_{k=1}^{n} b_{i} x_{i j}+e_{j}
$$

em que $x_{i j}$ representa $\mathrm{n}$ variáveis indicadoras (uma para cada genótipo marcador). Por exemplo, para um retrocruzamento: $x_{i j}=1$ se 0 indivíduo $j$ possui genótipo (alelo) marcador $i ; x_{i j}=0$ se outros casos.

O teste de máxima verossimilhança $(\mathrm{ML})$ é bastante utilizado para 0 mapeamento de QTLs. Este é um método poderoso, pois usa a informação total da distribuição caráter-marcador. Para este método, as equações são resolvidas através de programas computacionais uma vez que, para cada variante do modelo original, uma nova função de probabilidade precisa ser construída.

Assumindo que a distribuição fenotípica para um indivíduo com genótipo do QTL $\mathrm{Q}_{\mathrm{k}}$ seja normal, com média $\mu_{\mathrm{Qk}}$ e variância $\sigma^{2}$, a probabilidade para um indivíduo com valor fenotípico z e genótipo marcador $\mathrm{M}_{\mathrm{j}}$ é: 


$$
\ell\left(z \mid M_{j}\right)=\sum_{k=1}^{n} \varphi\left(z, \mu_{Q k}, \sigma^{2}\right) \operatorname{Pr}\left(Q_{k} \mid M_{j}\right)
$$

em que $\varphi\left(z, \mu_{Q k}, \sigma^{2}\right)$ representa a função de densidade para a distribuição normal com média $\mu_{Q k}$ e variância $\sigma^{2}$; sendo considerado um total de $\mathrm{n}$ genótipos QTLs. Esta probabilidade é uma distribuição de uma combinação de modelos. As proporções dessa combinação (indicadas por $\operatorname{Pr}\left(Q_{k} \mid M_{j}\right)$ são funções do mapa genético e do delineamento experimental, enquanto os efeitos do QTL entram somente através da média $\left(\mu_{Q k}\right)$ e da variância $\left(\sigma^{2}\right)$ da referida distribuição.

O teste para verificar se um QTL está ligado ao marcador, é baseado na estatística da razão de verossimilhança:

$$
L R=-2 \ln \left[\frac{\max L(H a)}{\max L(H o)}\right]
$$

em que $H_{a}$ refere-se à hipótese da presença de um QTL ligado ao marcador, e $H_{0}$ refere-se à hipótese da ausência de ligação de um QTL a esse marcador, com a pressuposição de que a distribuição dos fenótipos é normal.

No mapeamento de QTLs é muito comum o uso do $L O D$ score. A diferença entre o $L O D$ score e estatística LR é a base do logaritmo usada no teste. O teste LR utiliza logaritmos naturais e o LOD score utiliza logaritmo na base 10. A estatística LR é interpretada como a probabilidade de ocorrência dos dados, sob a hipótese nula, a qual é testada usando a distribuição teórica de qui-quadrado. O $L O D$ score não necessita de distribuição teórica para a sua interpretação. Por exemplo, um LOD score igual a 3 indica que a hipótese alternativa é $10^{3}=1000$ vezes mais provável de ocorrer do que a hipótese nula (Lynch \& Walsh, 1998; Falconer \& Mackay, 1996).

A posição do QTL no mapa é obtida pela estatística LR como uma função da posição de mapa do suposto QTL. As probabilidades da detecção e da estimativa da posição do QTL ligado, estão acopladas. Se a razão de verossimilhança exceder o limiar crítico para aquele cromossomo, isto fornece evidência de QTLs ligados à marca, sendo a posição estimada pelo pico da 
probabilidade do mapa. Se o pico não exceder o limiar crítico, não existe evidências para aceitar a presença de QTL na região (Lynch \& Walsh, 1998).

Os métodos de marcas simples e mapeamento por intervalo simples assumem um só QTL ligado a um marcador de interesse, não podendo detectar a presença de vários QTLs e, portanto, definir se um efeito significativo em vários intervalos ligados por marcadores é devido a um QTL ou a vários QTLs ligados. A maioria dos métodos desenvolvidos para um só QTL pode ser estendido para múltiplos QTLs. Para isso é necessário considerar marcadores adicionais e usar a probabilidade condicional para genótipos multilocos (Lynch \& Walsh, 1998).

Sabe-se que a distribuição da razão de verossimilhança pode ser aproximada pela distribuição de qui-quadrado. Contudo, no caso de mapeamento de QTLs, deve-se determinar o nível de significância dessa estatística usando uma distribuição empírica obtida com permutações, visto que os parâmetros (fenótipos e marcadores) do modelo não são independentes (Churchill \& Doerge, 1994; Doerge \& Churchill, 1996).

Para cada experimento de mapeamento um grande número de testes de associação caráter-marcador é realizado. Assim, o nível de significância $(\alpha)$ para esse grande número de testes pode ser obtido de diversas formas. $O$ teste mais efetivo para a obtenção do nível de significância utiliza um procedimento de reamostragem tal como, por exemplo, o teste de permutação. A análise é realizada muitas vezes em um conjunto de dados que são gerados pelo embaralhamento apropriado dos dados originais (Churchill \& Doerge, 1994; Doerge \& Churchill, 1996). Isso gera uma amostra com a informação original para os marcadores, mas com valores do caráter designados casualmente sobre o genótipo, sendo que o teste estatístico é realizado nesta nova "amostragem". Este procedimento é repetido diversas vezes gerando uma distribuição empírica do teste sob a hipótese de não existir associação carátermarcador. Há sugestões de que 1000 reamostragens seriam suficientes para um nível de significância de 5\% (Churchill \& Doerge, 1994). 


\subsubsection{Estimativas de efeitos aditivos e dominantes de QTLS}

Para a obtenção das estimativas dos efeitos aditivos e dos efeitos dominantes de um QTL, são requeridas informações de todos os três genótipos do marcador. Então, essa estimativa só poderá ser obtida utilizando-se delineamentos experimentais que permitem a ocorrência desses três genótipos, como por exemplo, populações $F_{2}$. Nesses casos, o efeito de dominância pode ser estimado usando os procedimentos demonstrados a seguir.

Considere uma população $F_{2}$ genotipada para um marcador e com um QTL ligado a esse marcador, com freqüência de recombinação $r$. Os valores genotípicos do QTL são (Lynch \& Walsh, 1998):

$$
\mu_{Q Q}=\mu+a \quad \mu_{Q q}=\mu+d \quad e \quad \mu_{q q}=\mu-a,
$$

em que a refere-se ao valor aditivo e $d$ ao valor de dominância. Aplicando a probablidade condicional, tem-se:

$$
\mu_{M j}=\sum_{k=1}^{n} \mu_{Q k} \operatorname{Pr}\left(Q_{k} \mid M_{j}\right) .
$$

Os valores médios dos genótipos serão:

$$
\begin{aligned}
& \mu_{M M}=\mu+(1-2 r) a+2 r(1-r) d, \\
& \mu_{M m}=\mu+\left[(1-r)^{2}+r^{2}\right] d \mathrm{e} \\
& \mu_{m m}=\mu-(1-2 r) a+2 r(1-r) d,
\end{aligned}
$$

e os efeitos aditivos e dominantes são estimados pelos contrastes:

$$
\begin{aligned}
& E(a)=\mu_{M M}-\mu_{m m}=2(1-2 r) a \mathrm{e} \\
& E(d)=\mu_{M M}+\mu_{m m}-2 \mu_{M m}=2\left(1-2 r^{2}\right) d .
\end{aligned}
$$


Saliente-se que estas estimativas de " $a$ " e de " $d$ " são viesadas, pois dependem da taxa de recombinação entre o marcador e o QTL. Dessa forma, para $r=1 / 2: E(a)=E(d)=0$.

Pode-se notar que, enquanto os contrastes de médias do marcador podem ser usados para a estimação de $\sum_{i=1}^{n}\left(1-2 r_{i}\right) a_{i}$ e de $\sum_{i=1}^{n}\left(1-2 r_{i}\right) d_{i}$, eles subestimam as magnitudes de $a$ e de $d$ pela taxa de recombinação $\left(1-2 r_{i}\right)$.

Atualmente, o procedimento mais utilizado para mapear QTLs é aquele em que se utiliza de informações que podem ser obtidas de todos os marcadores, associado à análise com marcadores adjacentes. Este tipo de análise é denominado de mapeamento por intervalo composto (CIM). Nesta metodologia considera-se que os efeitos dos QTLs fora do intervalo de análise podem interferir na variância do caráter em estudo e, portanto, interferir na detecção e mapeamento de QTL(s) no intervalo em análise. Para minimizar os efeitos destes QTLs fora do intervalo em análise, estes são incluídos na análise como cofatores, resultando em aumento considerável no poder de detecção, na estimativa da posição e nos efeitos genéticos dos QTLs nos intervalos considerados (Jansen, 1992; 1993; Jansen e Stam, 1994; Jansen et al., 1995; Zeng, 1993, 1994). Neste modelo, tem-se:

$$
Y_{j}=b_{0}+b_{1} X_{1 j}+b_{2} X_{2 j}+\sum_{k=1}^{n}\left(b_{k} X_{j k}\right)+e_{j}
$$

em que:

$Y_{j}$ : valor fenotípico médio da planta $j$,

$b_{0}$ : intercepto ou a média do caráter,

$b_{1}$ : coeficiente de regressão relacionado com o efeito aditivo,

$b_{2}$ : coeficiente de regressão relacionado com o efeito de dominância,

$b_{k}$ : coeficiente de regressão da k-ésima marca fora do intervalo considerado,

$X_{l j}$ : é a variável indicadora para os efeitos aditivos, cujo valor depende da probabilidade condicional do QTL estar ligado aos marcadores flanqueadores, $X_{2 j}$ : variável indicadora para os efeitos dominantes cujo valor depende da probabilidade condicional do QTL estar ligado aos marcadores flanqueadores, $X_{j k}$ : variável indicadora que apresenta valor que depende do genótipo da késima marca fora do intervalo considerado, 
$e_{j}$ : resíduo com $\cap \mathrm{N}\left(0, \sigma^{2}\right)$.

Este modelo considera como cofatores as $\mathrm{k}$ marcas, fora do intervalo, que têm efeito no fenótipo. Esses cofatores são determinados previamente através de uma análise de regressão múltipla usando do procedimento stepwise (Zeng, 1994). Nessa situação é possível construir um modelo para cada posição no genoma, uma vez que $X_{1 j}$ e $X_{2 j}$ consideram as probabilidades condicionais do QTL estar ligado aos marcadores. Em cada posição do genoma é testada a significância dos efeitos aditivos e de dominância do modelo. Este teste é realizado pela razão de verossimilhança (LR) (Lynch \& Walsh, 1998).

\subsection{Delineamento III, componentes de variância e marcadores moleculares}

O delineamento III (Comstock \& Robinson, 1952), é um delineamento genético cujo material experimental é composto de uma população de plantas $F_{2}$, originadas do cruzamento entre duas linhagens endogâmicas, retrocruzadas para ambos os parentais. O delineamento III foi proposto para estimar os componentes da variância genética e o grau médio de dominância de caracteres quantitativos.

Para a estimação dos parâmetros genéticos, caracteres quantitativos são avaliados para as progênies retrocruzadas com ambos os parentais. Uma análise de variância para cada caráter fornece estimativas das funções quadráticas dos efeitos dominantes e dos efeitos aditivos dos locos. O grau médio de dominância é obtido pela razão desses dois efeitos.

Cockerham \& Zeng (1996) utilizaram o delineamento III de Comstock \& Robinson (1952) para incorporar marcadores moleculares. A teoria e a análise estatística para contrastes ortogonais e para interação contraste $x$ ambiente, para um único loco marcador, e a caracterização dos efeitos dos QTLs, foram apresentados em detalhes por estes autores. Estes contrastes são formados entre as médias fenotípicas das progênies retrocruzadas de acordo com o genótipo e com o retrocruzamento a que pertencem. Comparados com a análise de variância, que fornece funções quadráticas dos efeitos, os contrastes dos marcadores fornecem funções lineares dos efeitos do QTL. 
Uma análise de variância é realizada para cada marcador, sendo que as fontes de variação são derivadas dos contrastes entre as médias fenotípicas de cada genótipo dentro de cada retrocruzamento em cada ambiente, e das interações desses contrastes com os ambientes avaliados. Essa análise permite estimar os efeitos principais (aditivos e dominantes) e os efeitos das interações interalélicas (epistasia), e detectar a presença/ausência de mais que um QTL ligado ao mesmo marcador.

\subsubsection{Componentes de variância}

O delineamento III (Comstock \& Robinson, 1952), é um delineamento genético cujo material experimental é composto por $\mathrm{n}$ pares de progênies obtidas pelo retrocruzamento de $n$ plantas $F_{2}$ ao acaso para cada linhagem parental. Os membros de cada par de progênies possuem o mesmo parental masculino (planta $F_{2}$ ), porém, possuem diferentes parentais femininos (as duas linhagens endogâmicas). As progênies originadas desses retrocruzamentos são, pois, meias-irmãs. As duas linhagens endogâmicas são as mesmas para todos os pares de progênies. É bom salientar que, na proposta original do delineamento III, as plantas $F_{2}$ são usadas como doadoras de pólen. Os autores apresentaram a análise de variância para as progênies $F_{2}$ retrocruzadas (Tabela 1), considerando um ambiente.

Tabela 1. Análise de variância do delineamento III segundo Comstock \& Robinson (1952).

\begin{tabular}{lccc}
\hline Fonte de variação & $\mathrm{GL}$ & $\mathrm{QM}$ & $\mathrm{E}(\mathrm{QM})$ \\
\hline Repetições & $(\mathrm{k}-1)$ & & \\
Linhagens parentais $(\mathrm{T})$ & 1 & & \\
Progênies $\mathrm{F}_{2}(\mathrm{P})$ & $(\mathrm{i}-1)$ & $\mathrm{QM}$ & $\sigma_{R}^{2}+2 k \sigma_{P}^{2}$ \\
$(\mathrm{PxT})$ & $(\mathrm{i}-1)$ & $\mathrm{QM} \mathrm{PT}_{\mathrm{P}}$ & $\sigma_{R}^{2}+k \sigma_{P T}^{2}$ \\
Resíduo & $(2 \mathrm{i}-1)(\mathrm{k}-1)$ & $\mathrm{Q}_{\mathrm{R}}$ & $\sigma_{R}^{2}$ \\
\hline
\end{tabular}


Os estimadores dos componentes de variância, obtidas a partir dessa análise de variância, são os seguintes:

Variância de progênies $\left(\sigma_{P}^{2}\right)$ :

$$
\hat{\sigma}_{P}^{2}=\left(Q M_{P}-Q M_{R}\right) / 2 k
$$

Variância da interação progênies com linhagens parentais $\left(\sigma_{P T}^{2}\right)$ :

$$
\hat{\sigma}_{P T}^{2}=\left(Q M_{P T}-Q M_{R}\right) / k
$$

Variância do resíduo $\left(\sigma_{R}^{2}\right)$ :

$$
\hat{\sigma}_{R}^{2}=\mathrm{QM}_{\mathrm{R}}
$$

Considere um loco qualquer com os alelos $B$ e b, e os genótipos das linhagens parentais endogâmicas como bb para L1 e BB para L2. Os efeitos dos desvios da média são $a$ (aditivo) para BB, $d$ (dominante) para Bb e - $a$ para bb. Considerando as freqüências de $(1 / 4) \mathrm{BB},(1 / 2) \mathrm{Bb}$ e (1/4)bb para a população $F_{2}$, e seu retrocruzamento para as duas linhagens parentais, os conteúdos genéticos dos componentes de variância são (Comstock \& Robinson,1952):

$$
\sigma_{P}^{2}=(1 / 8) \sum_{i} a_{i}^{2} \quad \text { e } \quad \sigma_{P T}^{2}=(1 / 4) \sum_{i} d_{i}^{2},
$$

considerando vários locos independentes entre si para uma determinada característica quantitativa, e que $\sigma_{A}^{2}=(1 / 2) \sum_{i} a_{i}^{2}, \quad \sigma_{D}^{2}=(1 / 4) \sum_{i} d_{i}^{2}$ e $G M D=$ $\left(2 \sigma_{D}^{2} / \sigma_{A}^{2}\right)^{1 / 2}$, tem-se:

$$
\sigma_{P}^{2}=(1 / 4) \sigma_{A}^{2} \quad \text { e } \quad \sigma_{P T}^{2}=\sigma_{D}^{2},
$$

e as estimativas das variâncias genéticas aditiva e dominante são:

$$
\hat{\sigma}_{A}^{2}=4 \hat{\sigma}_{P}^{2} \quad \text { e } \quad \hat{\sigma}_{D}^{2}=\hat{\sigma}_{P T}^{2},
$$


e o grau médio de dominância (GMD):

$$
G \hat{M} D=\left(\hat{\sigma}_{P T}^{2} / 2 \hat{\sigma}_{P}^{2}\right)^{1 / 2}=\left(\sum_{i} d_{i}^{2} / \sum_{i} a_{i}^{2}\right)^{1 / 2},
$$

em que $a$ e $d$ referem-se aos efeitos aditivos e aos efeitos dominantes, respectivamente; $\sum_{i} a_{i}^{2}$ e $\sum_{i} d_{i}^{2}$ referem-se ao somatório dos efeitos aditivos de todos os locos e ao somatório dos efeitos dominantes de todos os locos, respectivamente; $P$ refere-se a progênies; $P T$ refere-se à interação das progênies com as linhagens parentais.

Comstock \& Robinson (1952) destacaram que, em presença do desequilíbrio de ligação, as fases de repulsão gênica proporcionam o aparecimento de valores superestimados do grau médio de dominância. Contudo, os efeitos das ligações gênicas são dissipados através da recombinação genética ao longo das gerações de cruzamentos ao acaso, assim a pseudo-sobredominância decresce e desaparece com o avanço de tais gerações. Os autores fornecem as explicações teóricas para o fenômeno da pseudo-sobredominância. Quando dois locos gênicos estiverem ligados, uma covariância entre seus efeitos aditivos, a qual será positiva ou negativa a depender da fase de ligação, e uma covariância entre seus efeitos de dominância estarão presentes. Quando a fase de ligação gênica for de associação, a covariância entre os efeitos aditivos será positiva, elevando assim o valor da variância genética aditiva. Quando a fase de ligação gênica for de repulsão, a covariância entre os efeitos aditivos será negativa, diminuindo portanto, o valor da variância genética aditiva. Para ambas as fases (associação e repulsão) a covariância entre os efeitos de dominância será sempre positiva e, portanto, elevará o valor da variância de dominância.

Mather \& Jinks (1982) discorreram sobre a influência do desequilíbrio de ligação nas estimativas dos componentes da variância genética. Em presença do desequilíbrio de ligação, a variância aditiva será $\mathrm{V}_{\mathrm{A}^{\prime}}=\mathrm{V}_{\mathrm{A}} \pm 2$ (1-2r) $a_{1} a_{2}$, em que $V_{A}$ é a variância aditiva original, $r$ a taxa de recombinação entre os locos ligados e $a_{1}$ e $a_{2}$ os efeitos aditivos dos genes dos locos ligados 1 e 2 , respectivamente, enquanto a variância dominante será $V_{D^{\prime}}=V_{D}+2(1-2 r)^{2} d_{1} d_{2}$, em que $V_{D}$ é a variância dominante original, $r$ a taxa de recombinação entre os 
locos ligados e $d_{1}$ e $d_{2}$ os efeitos de dominância dos locos ligados 1 e 2, respectivamente. Observando-se as expressões enunciadas, constata-se que tanto a magnitude na alteração da variância aditiva quanto a magnitude na alteração da variância dominante dependem da taxa de recombinação entre os locos. Quanto maior a taxa de recombinação, mais rápida será a aproximação ao equilíbrio e, portanto, menor será a alteração nos parâmetros mencionados.

Assim, nas gerações iniciais de um cruzamento entre duas linhagens contrastantes, portanto em presença do desequilíbrio de ligação cujas fases estarão predominantemente em repulsão gênica, o grau médio de dominância, representado pela proporção dos efeitos de dominância sobre os efeitos aditivos, poderá acusar sobredominância, já que a variância genética aditiva estará subestimada e a variância genética dominante estará superestimada. Contudo, em presença do desequilíbrio de ligação cujas fases forem predominantemente de associação gênica, tanto a variância genética aditiva como a variância genética dominante estarão inflacionadas. Com o avanço das gerações através de cruzamentos ao acaso, a recombinação entre os locos gênicos ligados proporcionará o alcance do equilíbrio de ligação e, consequentemente, o desaparecimento da pseudo-sobredominância inicial (Comstock \& Robinson, 1952).

Robinson et al. (1949) obtiveram estimativas do grau médio de dominância, em milho, utilizando o delineamento III com progênies $F_{2}$ de três diferentes híbridos derivados de cruzamentos entre linhagens endogâmicas. Oito caracteres foram avaliados: altura da planta, altura da espiga, extensão da palha, escore da palha, número de espigas, comprimento da espiga, diâmetro da espiga e produção de grãos. Os caracteres altura da planta e altura da espiga indicaram pouca ou nenhuma dominância. O caráter extensão da palha indicou dominância completa, enquanto os caracteres escore da palha, número de espigas, comprimento da espiga e diâmetro da espiga apresentaram dominância parcial a completa. A possibilidade de existência de sobredominância na ação de locos determinando o caráter produção de grãos foi indicada, visto que sua estimativa foi de 1,64. Contudo, os autores salientaram que é teoricamente possível obter estimativas de sobredominância para locos que apresentam dominância parcial em decorrência de fortes 
ligações gênicas, em fases de repulsão, que não foram quebradas com apenas uma geração de cruzamentos ao acaso.

Gardner et al. (1953), estimaram o grau médio de dominância para dez caracteres quantitativos em duas populações $F_{2}$ de milho. Os caracteres quantitativos avaliados foram: produção de grãos, número de espigas, comprimento da espiga, diâmetro da espiga, número de fileiras de grãos, altura da planta, altura da espiga, número de dias para o florescimento masculino, número de folhas e comprimento da folha. Os resultados mostraram que o grau médio de dominância para a maioria dos caracteres variou da dominância parcial à completa. No entanto, para o comprimento da espiga em uma população, e a produção de grãos, nas duas populações, cujas estimativas para GMD foram 1,80, 2,14 e 1,58, respectivamente, forneceram forte evidência favorecendo a hipótese da sobredominância ou a hipótese da existência de considerável ligação entre locos com ação gênica parcial a completamente dominante. Os autores enfatizaram, entretanto, a necessidade de investigar gerações mais avançadas dos cruzamentos, a fim de inferir se as ligações gênicas causaram ou não uma elevação nas estimativas obtidas nas populações $F_{2}$.

Gardner \& Lonnquist (1959), utilizando progênies $F_{2}$ e conduzidas por recombinação por seis gerações $\left(\mathrm{F}_{8}\right)$, em milho, obtiveram estimativas da variância genética aditiva, da variância genética dominante e do grau médio de dominância. Os caracteres avaliados foram produção de grãos, número de espigas por planta, comprimento da espiga, diâmetro da espiga, altura da planta, altura da espiga e florescimento masculino. A geração $F_{2}$ forneceu estimativas do grau médio de dominância para a produção de grãos de 1,59, indicando que tais genes apresentavam o fenômeno de sobredominância. Para a geração $F_{8}$, entretanto, as estimativas indicaram apenas dominância completa, com valor estimado de 0,93. As estimativas verificadas do grau médio de dominância e da variância genética dominante foram, para todos os caracteres quantitativos estudados, superiores na geração $F_{2}$ quando comparadas com aquelas obtidas para a geração $F_{8}$. As estimativas constatadas da variância genética aditiva na população $F_{2}$ foram menores do que as obtidas para a população $F_{8}$ para todos os caracteres avaliados, exceto para dois caracteres do primeiro retrocruzamento: produção de grãos e para 
altura da planta. Segundo os autores, esses resultados sugerem que as estimativas previamente obtidas para o caráter produção de grãos estavam superestimadas em decorrência de fases de repulsão entre locos ligados que apresentavam, na verdade, ação gênica situada apenas na faixa da dominância parcial ou da dominância completa. Houve forte evidência de que ligações gênicas foram quebradas ao longo das gerações de cruzamentos ao acaso, permitindo, assim, a ocorrência de recombinações e favorecendo, na geração $F_{8}$, o surgimento de novas combinações gênicas que não existiam na geração $F_{2}$. Os resultados obtidos, embora indicando dominância parcial ou completa para os locos dos caracteres quantitativos estudados, não excluem porém, a possibilidade de existência de ação gênica sobredominante em um ou mais locos isoladamente. Entretanto, de acordo com os autores, se a sobredominância possuísse uma importância considerável na determinação da produção de grãos, as estimativas do grau médio de dominância para este caráter provavelmente permaneceriam constantes com 0 decorrer das gerações.

Gardner (1963) apresentou resultados de diversos experimentos envolvendo populações $F_{2}$ em milho. A maior parte das estimativas obtidas utilizando o delineamento III indicaram sobredominância para produção de grãos, com valores de GMD entre 1,31 e 2,26 (exceto para uma estimativa com valor 0,56 ). Os dados proporcionaram evidências que favorecem a hipótese da influência das ligações gênicas na obtenção de estimativas de parâmetros genéticos e, assim, o autor concluiu que a presença das ligações em fase de repulsão gênica provoca o aparecimento de estimativas de GMD na faixa da sobredominância, quando estas são obtidas em gerações iniciais de recombinação. $O$ autor sugeriu, ainda, que o grau médio de dominância para o caráter produção de grãos, em milho, encontra-se na amplitude da dominância parcial, hipótese que não excluiria, entretanto, a possibilidade de existência de ação gênica sobredominante em alguns locos.

Moll et al. (1964) utilizaram progênies $F_{2}$ retrocruzadas para as duas linhagens parentais seguindo 0 modelo do delineamento III. Os retrocruzamentos foram realizados nas gerações $F_{2}, F_{8}$ e $F_{12}$ de um cruzamento, e nas gerações $F_{2}, F_{8}$ e $F_{13}$ do outro cruzamento. As gerações avançadas $\left(F_{8}, F_{12}\right.$, e $\left.F_{13}\right)$ foram derivadas de recombinações dentro das 
populações visando, assim, permitir a ocorrência de recombinação genética com a subseqüente dissipação da possível pseudo-sobredominância, presumida por Robinson et al. (1949). Os caracteres quantitativos estudados foram a produção de grãos, o número de espigas, o diâmetro da espiga, o comprimento da espiga, a altura da espiga, a altura da planta e o número de dias para o florescimento masculino. Um dos cruzamentos, com GMD =1,52, proporcionou evidência de possível sobredominância para a produção de grãos na geração $F_{2}$, enquanto que o outro, com $G M D=1,04$, evidenciou dominância completa. Houve redução nas estimativas da variância dominante e do grau médio de dominância para todos os caracteres com as gerações avançadas de cruzamentos ao acaso $\left(F_{12}\right.$ e $\left.F_{13}\right)$, indicando, assim, que os efeitos das ligações haviam causado uma elevação nas estimativas obtidas nas populações $F_{2}$. Estimativas do GMD para a produção de grãos, nas gerações avançadas $F_{8}$, $F_{12}$ e $F_{13}$, não foram significativamente diferentes de 1,0, o valor da dominância completa. Os autores concluíram que a sobredominância não é um tipo de ação gênica preponderante nas populações avaliadas. As conclusões estiveram de acordo com as considerações teóricas dos autores, os quais ponderaram que, na presença do desequilíbrio de ligação, as fases de repulsão tendem a simular efeitos de sobredominância, os quais são indistinguíveis dos verdadeiros efeitos de sobredominância quando a freqüência de recombinação é quase nula. Entretanto, os efeitos de uma pseudo-sobredominância devem diminuir e até mesmo desaparecer gradativamente, com a aproximação ao equilíbrio de ligação sob cruzamentos ao acaso, a uma taxa proporcional à freqüência de recombinação entre os locos gênicos. Esses resultados confirmam as deduções feitas anteriormente por Robinson et al. (1949).

Moreno-González (1975) ${ }^{2}$, citado por Moreno-González et al. (1975), estendeu a teoria apresentada para o delineamento III por Comstock \& Robinson (1952). O autor demonstrou que se a freqüência gênica for altamente divergente entre dois genótipos, torna-se desprezível o fato de os parentais serem ou não linhagens endogâmicas. Então, Moreno-González et al. (1975) avaliaram progênies $F_{2}$ e $F_{6}$ (originada de recombinações da população $F_{2}$ ) retrocruzadas para ambas as populações parentais, seguindo o modelo do delineamento III. As populações utilizadas foram Illinois High Oil (IHO) e Illinois

2 MORENO-GONZÁLEZ, J. A design III study of linkage disequilibrium for percent oil in maize. Urbana, 1975. 115p. Thesis (MS) - University of Illinois. 
Low Oil (ILO) e estavam na $68^{\mathrm{a}}$ geração de seleção divergente. Foi avaliado o caráter teor de óleo dos grãos objetivando obter estimativas da variância genética aditiva, variância genética dominante e do grau médio de dominância, e medir o efeito da influência das ligações gênicas em tais estimativas. As conclusões obtidas foram as seguintes: 1) a estimativa da variância genética aditiva foi cerca de oito vezes maior que a estimativa da variância genética dominante na geração $F_{2}$, enquanto, na geração $F_{6}$, foi apenas cerca de quatro vezes maior; 2) a estimativa da variância genética aditiva na geração $F_{6}$ foi metade daquela obtida na geração $F_{2}$, sugerindo assim que muitos locos que controlam o caráter porcentagem de óleo estavam ligados na fase de associação, nas linhagens parentais.

Dudley (1994), usando as populações de milho Illinois High Protein (IHP), Illinois Low Protein (ILP), Reverse Low Protein (RLP) e Reverse High Protein (RHP), avaliou os retrocruzamentos para ambas as linhagens parentais (delineamento III) das progênies $F_{2}$ e $F_{6}$ (originada de cruzamentos ao acaso da população $F_{2}$ ) dos cruzamentos IHPxILP, IHPxRHP, RHPxRLP e ILPxRLP. Foram avaliados os caracteres produção de grãos, porcentagem de proteína nos grãos, porcentagem de óleo nos grãos, porcentagem de umidade dos grãos e altura da planta. Os resultados demonstraram que as estimativas da variância aditiva para porcentagem de proteína nos cruzamentos IHPxILP e ILPxRLP foram significativamente menores na geração $F_{6}$ daquelas obtidas da geração $F_{2}$, indicando a presença de ligação em fase de associação nas linhagens parentais e a quebra dessa ligação pelas gerações de recombinação. Também demonstraram, para o cruzamento IHPxILP, uma redução significativa da variância dominante para produção de grãos da geração $F_{2}$ para a geração $F_{6}$, sugerindo a presença de ligação na fase de repulsão. $O$ autor concluiu que a seleção divergente praticada por longo tempo foi eficiente no desenvolvimento de ligação na fase de associação para porcentagem de proteína, concordando com Moreno-González et al. (1975), e que os cruzamentos ao acaso dissipam o desequilíbrio de ligação, concordando com Gardner et al. (1953), Moll et al. (1964) e Moreno-González et al. (1975).

Wolf et al. (2000), usando as linhagens de milho B73 e Mo17, avaliaram uma população $F_{2}$ retrocruzada para ambas as linhagens endogâmicas parentais (delineamento III) e progênies derivadas dessa população. Foram 
avaliados 16 caracteres, entre os quais, produção de grãos, diâmetro da espiga, comprimento da espiga, número de fileiras de grãos da espiga, número de espiga por planta, altura da planta, altura da espiga, florescimento masculino, florescimento feminino e intervalo de florescimento. As variâncias genéticas foram estimadas usando as análises do delineamento III e de quadrados mínimos ponderados. Ambas as análises demonstraram que a variância dominante foi maior do que a variância aditiva para produção de grãos. Para outros caracteres a variância aditiva foi mais importante do que a variância dominante. O valor do grau médio de dominância de 2,44 para o caráter produção de grãos, sugere a existência de efeitos gênicos de sobredominância ou pseudo-sobredominância por causa do desequilíbrio de ligação na geração $F_{2}$. Os autores salientaram que a variância aditiva para produção de grãos pode ter sido suprimida por uma grande interação com o ambiente, inflacionando o grau médio de dominância.

\subsubsection{Delineamento III com marcadores moleculares}

Cockerham \& Zeng (1996) apresentaram uma metodologia de análise genética de caracteres quantitativos associando 0 delineamento III de Comstock \& Robinson (1952) com marcadores moleculares. Os autores apresentaram os fundamentos para a análise, as expressões e fórmulas para se proceder a análise e a aplicaram aos dados de Stuber et al. (1992) para diversos caracteres em milho. Esta análise é realizada considerando um único marcador de cada vez. A seguir será apresentada em detalhes a metodologia, sua interpretação genética e os resultados obtidos pelos autores com milho.

No delineamento III, cada planta $F_{2}$, ou progênie $F_{2: 3}$, é retrocruzada simultaneamente para as duas linhagens parentais. As progênies retrocruzadas resultantes são avaliadas em experimentos com repetições. As plantas $F_{2}$ são genotipadas. Para cada marcador polimórfico, pode-se construir 4 contrastes ortogonais envolvendo as médias fenotípicas para cada genótipo do marcador, sendo que dois destes contrastes envolvem comparação de médias e outros dois são devidos à interação. 
Para a construção dos contrastes, tem-se dois graus de liberdade para marcadores e dois graus de liberdade para a interação entre os marcadores e as linhagens parentais. Denotando de $\bar{X}_{M M}^{L 1}, \bar{X}_{M m}^{L 1}$ e $\bar{X}_{m m}^{L 1}$ as médias dos valores fenotípicos do retrocruzamento com a linhagem 1, associados aos três genótipos do marcador $\mathrm{M}$, e $\bar{X}_{M M}^{L 2}, \bar{X}_{M m}^{L 2}$ e $\bar{X}_{m m}^{L 2}$.as médias dos valores fenotípicos do retrocruzamento com a linhagem 2 , associados aos três genótipos do marcador M, os contrastes são:

$$
\begin{aligned}
& \mathrm{C}_{1}: \bar{X}_{M M}^{L 1}+\bar{X}_{M M}^{L 2}-\bar{X}_{m m}^{L 1}-\bar{X}_{m m}^{L 2} \text {, ou seja: } \\
& \mathrm{C}_{1}: \bar{X}_{M M}-\bar{X}_{m m},
\end{aligned}
$$

que se refere à diferença entre os genótipos homozigotos do marcador envolvendo os dois retrocruzamentos. Note que:

$$
\bar{X}_{M M}=\left(\bar{X}_{M M}^{L 1}+\bar{X}_{M M}^{L 2}\right) / 2 \text { e } \quad \bar{X}_{m m}=\left(\bar{X}_{m m}^{L 1}+\bar{X}_{m m}^{L 2}\right) / 2 .
$$

O segundo contraste é:

$$
\begin{aligned}
& \mathrm{C}_{2}: \bar{X}_{M M}^{L 1}+\bar{X}_{M M}^{L 2}+\bar{X}_{m m}^{L 1}+\bar{X}_{m m}^{L 2}-2 \bar{X}_{M m}^{L 1}-2 \bar{X}_{M m}^{L 2} \text {, ou seja: } \\
& \mathrm{C}_{2}: \bar{X}_{M M}+\bar{X}_{m m}-2 \bar{X}_{M m},
\end{aligned}
$$

que se refere à diferença entre as médias dos homozigotos e heterozigotos do marcador envolvendo os dois retrocruzamentos. Note que, também,

$$
\bar{X}_{M m}=\left(\bar{X}_{M m}^{L 1}+\bar{X}_{M m}^{L 2}\right) / 2 .
$$

Agora, a suposição recai sobre as comparações do mesmo marcador para os dois retrocruzamentos:

$$
\mathrm{C}_{3}:\left(\bar{X}_{M M}^{L 1}-\bar{X}_{m m}^{L 1}\right)=\left(\bar{X}_{M M}^{L 2}-\bar{X}_{m m}^{L 2}\right),
$$


que se refere ao contraste dos dados fenotípicos do marcador $\mathrm{M}$ retrocruzado com as linhagens 1 e 2, respectivamente. Reescrevendo-se, tem-se:

$$
\mathrm{C}_{3}: \bar{X}_{M M}^{L 1}-\bar{X}_{m m}^{L 1}-\bar{X}_{M M}^{L 2}+\bar{X}_{m m}^{L 2}
$$

E para o último contraste:

$$
\mathrm{C}_{4}:\left(\bar{X}_{M M}^{L 1}+\bar{X}_{m m}^{L 1}-2 \bar{X}_{M m}^{L 1}\right)=\left(\bar{X}_{M M}^{L 2}+\bar{X}_{m m}^{L 2}-2 \bar{X}_{M m}^{L 2}\right),
$$

que se refere ao contraste dos dados fenotípicos dos homozigotos com os heterozigotos do marcador $M$ retrocruzado com as linhagens 1 e 2, respectivamente. Desenvolvendo esta expressão, tem-se:

$$
\mathrm{C}_{4}: \bar{X}_{M M}^{L 1}+\bar{X}_{m m}^{L 1}-2 \bar{X}_{m m}^{L 1}-\bar{X}_{M M}^{L 2}-\bar{X}_{m m}^{L 2}+2 \bar{X}_{M m}^{L 2} .
$$

Os contrastes $\mathrm{C}_{3}$ e $\mathrm{C}_{4}$ referem-se às comparações dos contrastes com as médias dos marcadores oriundas das progênies retrocruzadas para as linhagens parentais 1 e 2 , enquanto os contrastes $C_{1}$ e $C_{2}$ referem-se às diferenças das médias envolvendo os valores fenotípicos dos dois retrocruzamentos. Assim, $\mathrm{C}_{1}$ é a diferença entre as médias dos marcadores homozigotos; $\mathrm{C}_{2}$ entre as médias dos homozigotos e heterozigotos; $\mathrm{C}_{3}$ é desenvolvido a partir da comparação da diferença entre as médias dos marcadores homozigotos para as duas linhagens parentais; e $\mathrm{C}_{4}$ é desenvolvido a partir da comparação entre as médias dos homozigotos e heterozigotos para as duas linhagens parentais.

Cockerham \& Zeng (1996) desenvolveram as esperanças genotípicas destes contrastes, considerando apenas um QTL ligado ao marcador, através da substituição dos genótipos pelos seus respectivos valores genotípicos apresentados na Tabela 2, e obtiveram:

$$
\mathrm{C}_{1}=2(1-2 r) a, \quad \mathrm{C}_{3}=2(1-2 r) d \quad \mathrm{e} \quad \mathrm{C}_{2}=\mathrm{C}_{4}=0,
$$

em que $\mathrm{r}$ é a taxa de recombinação entre o loco QTL e o marcador; $a$ representa os efeitos aditivos; $d$ representa os efeitos dominantes. 
Tabela 2. Constituição genotípica das progênies $F_{2}$ retrocruzadas com a linhagem parental 1 e com a linhagem parental 2, de acordo com o genótipo do marcador.

\begin{tabular}{ccc}
\hline Genótipo do & \multicolumn{2}{c}{ Genótipos das progênies retrocruzadas ${ }^{(\dagger)}$} \\
\cline { 2 - 3 } marcador & $\mathrm{L}_{2}(\mathrm{BB})$ & $\mathrm{L}_{1}(\mathrm{bb})$ \\
\hline $\mathrm{MM}$ & $(1-\mathrm{r}) \mathrm{BB}+\mathrm{rBb}$ & $(1-\mathrm{r}) \mathrm{Bb}+\mathrm{rbb}$ \\
$\mathrm{Mm}$ & $(\mathrm{BB}+\mathrm{Bb}) / 2$ & $(\mathrm{Bb}+\mathrm{bb}) / 2$ \\
$\mathrm{~mm}$ & $\mathrm{rBB}+(1-\mathrm{r}) \mathrm{Bb}$ & $\mathrm{rBb}+(1-\mathrm{r}) \mathrm{bb}$ \\
\hline${ }^{(t)} \mathrm{BB}, \mathrm{Bb}$ e bb referem-se aos genótipos de um QTL.
\end{tabular}

Nota-se que todos os contrastes são iguais a zero se a taxa de recombinação $(r)$ for igual a $1 / 2$. Se $r=0$, não se distingue o marcador do QTL. Os resultados devem ser somados para todos os QTLs com $r<1 / 2$ entre 0 marcador e o QTL. Considere $i$ o índice do marcador e $j$ o índice do QTL e $C_{i j}=$ (1-2rij $)$. Então, para o contraste 1 do iésimo marcador:

$$
\mathrm{C}_{\mathrm{i} 1}=2 \Sigma_{j} c_{i j} a_{j} .
$$

E correspondentemente para o contraste 3 :

$$
\mathrm{C}_{\mathrm{i} 3}=2 \Sigma_{j} c_{i j} d_{j} .
$$

Deve-se tomar cuidado na interpretação dos contrastes. $\mathrm{O}$ alelo $\mathrm{B}$, ou o alelo da linhagem parental 2, foi designado como o alelo favorável. Por outro lado, se o loco b, da linhagem parental 1, for o alelo favorável, então o valor de a será negativo. Desta forma, com alelos de diferentes locos de diferentes linhagens parentais, os efeitos tenderão ao cancelamento na soma. Também, $d$ será positivo se o alelo favorável for dominante e será negativo se o alelo não favorável for dominante. Em espécies alógamas, que possuem uma considerável depressão por endogamia, $d$ é positivo para a maior parte dos locos, originando menor possibilidade de cancelamento da soma.

A análise também foi estendida para incluir dois QTLs ligados a um mesmo marcador. Considerando dois locos (B e C) ligados a um marcador (M), os contrastes têm os seguintes conteúdos genéticos: 


$$
\begin{aligned}
& \mathrm{C}_{1}=2\left(1-2 r_{M B}\right)\left(a_{1}-\gamma / 2\right)+2\left(1-2 r_{M C}\right)\left(a_{2}-\phi / 2\right), \\
& \mathrm{C}_{2}=2 r_{B C}\left(1-2 r_{M B}\right)\left(1-2 r_{M C}\right)(\varepsilon+\omega), \\
& \mathrm{C}_{3}=2\left(1-2 r_{M B}\right)\left(d_{1}-\varepsilon / 2\right)+2\left(1-2 r_{M C}\right)\left(d_{2}-\varepsilon / 2\right) \mathrm{e} \\
& \mathrm{C}_{4}=2 r_{B C}\left(1-2 r_{M B}\right)\left(1-2 r_{M C}\right)(\phi+\gamma),
\end{aligned}
$$

em que $r_{M B}, r_{M C}$ e $r_{M C}$, referem-se às taxas de recombinação entre o marcador e os locos B ou C, e entre os locos B e C, respectivamente; $a_{1}$ e $a_{2}$ são os efeitos aditivos dos locos $\mathrm{B}$ e $\mathrm{C}$, e $d_{1}$ e $d_{2}$ são os efeitos de dominância dos locos $\mathrm{B}$ e $\mathrm{C}$, respectivamente, enquanto $\varepsilon, \omega, \phi$ e $\gamma$ referem-se aos efeitos de epistasia digênica aditivo $x$ aditivo, dominante $x$ dominante, aditivo $x$ dominante $e$ dominante $x$ aditivo, respectivamente.

Nota-se que os contrastes $\mathrm{C}_{1}$ e $\mathrm{C}_{3}$ mensuram principalmente os efeitos aditivos ( $a$ ) e dominantes $(d)$, respectivamente, enquanto os contrastes $\mathrm{C}_{2}$ e $\mathrm{C}_{4}$ mensuram os efeitos epistáticos aditivo $\mathrm{x}$ aditivo $(\varepsilon)$ e dominante $\mathrm{x}$ dominante $(\omega)$, e aditivo $x$ dominante $(\phi)$ e dominante $x$ aditivo $(\gamma)$. Quando os efeitos de epistasia estão presentes, estes contribuem para os efeitos aditivos em $\mathrm{C}_{1} \mathrm{e}$ para os efeitos dominantes em $\mathrm{C}_{3}$, enquanto que efeitos epistáticos distintos contribuem para os contrastes $\mathrm{C}_{2}$ e $\mathrm{C}_{4}$.

Para efeito de análise estatística, estes contrastes são transformados em coeficientes de regressão linear $\left(\beta_{k}\right)$ parciais, de uma análise de regressão múltipla. Assim, tem-se que:

$$
\beta_{k}=C d \sum_{1}^{6} X_{t}^{2}
$$

em que $X_{t}$ refere-se aos coeficientes que multiplicam os componentes dos respectivos contrastes. Assim:

$$
\beta_{1}=\mathrm{C}_{1} / 4 ; \quad \beta_{2}=\mathrm{C}_{2} / 12 ; \quad \beta_{3}=\mathrm{C}_{3} / 4 ; \quad \beta_{4}=\mathrm{C}_{4} / 12
$$


Pode-se notar que estes contrastes são zero se a taxa $r$ de recombinação for igual a 0,5 , e que se os coeficientes $\beta_{2}$ e/ou $\beta_{4}$ forem significativos, indicam a existência de epistasia e, consequentemente, a existência de mais de um loco ligado ao mesmo marcador. Saliente-se que a existência de significância para $\beta_{1}$ ou para $\beta_{3}$ indica a ligação de QTLs ao marcador em questão. Esse QTL apresentará efeito aditivo se $\beta_{1}$ for significativo, e efeito dominante se $\beta_{3}$ for significativo. Entretanto, mais de um QTL pode estar ligado ao marcador mas não apresentar efeitos epistáticos, isto é, não apresentar interação interalélica.

Segundo deduções de Cockerham \& Zeng (1996), quando o marcador está entre os QTLs B e $C$ e quando a taxa de recombinação entre esses dois QTLs $\left(r_{B C}\right)$ for igual a 1/4, a expressão $2 r_{B C}\left(1-2 r_{M B}\right)\left(1-2 r_{M C}\right)$ atinge seu valor máximo, que é 1/8. Esta expressão faz parte dos conteúdos genéticos dos contrastes 2 e 4, como está demonstrado acima, os quais ainda são divididos por 12 para a obtenção dos correspondentes coeficientes de regressão. Isto significa que o modelo é muito conservador para a detecção desses efeitos. Dessa forma, se um marcador detectar significância para os efeitos epistáticos, indicará que esses efeitos são muito pronunciados, uma vez que apenas uma pequena parte do total existente está sendo detectada. É necessário enfatizar mais uma vez que $\beta_{2}$ e $\beta_{4}$ detectam apenas os efeitos epistáticos resultantes da ligação entre QTLs em um mesmo marcador.

O principal atributo da análise de marcadores pelo delineamento III de Cockerham \& Zeng (1996) é a exploração dos efeitos dos QTLs, e não o mapeamento propriamente dito. Para a detecção de associação entre os marcadores e os caracteres quantitativos foi elaborada uma análise de variância para cada marcador, envolvendo os contrastes e suas interações com ambientes. As fontes de variação dessa análise foram derivadas dos contrastes entre as médias fenotípicas de cada genótipo dentro de cada retrocruzamento em cada ambiente, e das interações desses contrastes com os ambientes avaliados. As análises de variância para os marcadores são realizadas de acordo com a Tabela 4, apresentada na página 60.

Essa metodologia foi desenvolvida e aplicada por Cockerham \& Zeng (1996) usando os dados fenotípicos e de marcadores moleculares obtidos por Stuber et al. (1992). Então, visando uma discussão mais abrangente sobre a 
utilização do delineamento III na análise estatística e de marcadores, serão apresentados os resultados destes dois trabalhos.

Stuber et al. (1992), usando as linhagens endogâmicas de milho B73 e Mo17, avaliaram os retrocruzamentos de 264 progênies $F_{3}$ para ambas as linhagens parentais; a genotipagem foi realizada nas progênies $F_{3}$ com 73 marcadores. Os experimentos foram instalados em seis ambientes e com uma repetição em cada ambiente. Foram avaliados os caracteres produção de grãos, prolificidade, altura da espiga, altura da planta, florescimento masculino, teor de umidade nos grãos e área foliar da espiga. As análises foram realizadas separadamente para cada retrocruzamento. Os autores empreenderam o mapeamento de QTLs associados com os caracteres mensurados objetivando a exploração da heterose e da interação genótipos por ambientes, além da comparação entre dois métodos de mapeamento, de marcas simples e de mapeamento por intervalo. Os resultados obtidos demonstraram que ambos os métodos de mapeamento tiveram virtualmente os mesmos resultados para a detecção de QTLs para produção de grãos, exceto para o cromossomo 6 . Poucos QTLs foram detectados para os outros caracteres mensurados. Sempre que um QTL para produção de grãos foi detectado, o heterozigoto apresentou fenótipo superior ao respectivo homozigoto, com apenas uma exceção, sugerindo não somente sobredominância, ou pseudo-sobredominância, mas também que esses QTLs detectados exercem uma função importante na heterose. Esta conclusão foi reforçada por uma alta correlação entre produção de grãos e proporção de marcadores heterozigotos. Os efeitos epistáticos não foram considerados importantes para a manifestação dos caracteres avaliados. Apesar dos experimentos terem sido desenvolvidos em seis diferentes ambientes, houve pequena interação genótipos por ambientes para a maioria dos QTLs.

Cockerham \& Zeng (1996) aplicaram o modelo desenvolvido para análise dos marcadores com o delineamento III aos dados fenotípicos e genotípicos de Stuber et al. (1992). Em resumo, as análises detectaram vários QTLs em vários cromossomos para todos os caracteres avaliados. Também foram detectados efeitos epistáticos significativos.

Para o caráter produção de grãos, os autores detectaram que grande parte, $93,15 \%$, dos marcadores apresentaram significância para os efeitos 
dominantes, enquanto que $23,30 \%$ foram significativos para os efeitos aditivos e $41,1 \%$ para os efeitos epistáticos $\left(\beta_{2}\right.$ e/ou $\left.\beta_{4}\right)$. Este resultado evidencia a importância dos efeitos dominantes e epistáticos para a manifestação deste caráter. A magnitude dos efeitos dominantes foi maior do que a magnitude dos efeitos aditivos e epistáticos, entretanto, para alguns marcadores esta magnitude foi maior para os efeitos epistáticos do que para outros efeitos. Como salientaram Cockerham \& Zeng (1996), os efeitos epistáticos detectados de QTLs ligados aos marcadores referem-se a uma pequena porção dos efeitos reais existentes, indicando que o valor encontrado pode estar subestimado. Por isso, os resultados obtidos demonstram que os efeitos epistáticos podem ter tanta importância quanto os efeitos dominantes para a manifestação deste caráter.

Para as interações genótipos por ambientes, Cockerham \& Zeng (1996) encontraram apenas 9 marcadores (12,33\%) com significância, para o caráter produção de grãos. Os autores salientaram que era esperado um número maior de marcadores com significância para estas interações, uma vez que os experimentos foram conduzidos em seis ambientes e com apenas uma repetição para cada ambiente.

Para o caráter prolificidade, Cockerham \& Zeng (1996) relataram pequena porcentagem de marcadores com significância para os efeitos aditivos, dominantes e epistáticos, assim como para suas interações com ambientes. Entretanto, Stuber et al. (1992), já haviam salientado que a ausência de QTLs para este caráter é devido à falta de variabilidade entre as linhagens parentais usadas para a obtenção das progênies avaliadas.

Para os caracteres altura da planta e altura da espiga, Cokerham \& Zeng (1996) relataram grande similaridade em relação ao número e à localização dos marcadores com efeitos significativos. Foi detectado grande porcentagem de marcadores com significância para os efeitos dominantes, principalmente para o caráter altura da planta. Os efeitos dominantes foram positivos para quase todos os marcadores. Os resultados indicaram a presença de efeitos epistáticos em todos os cromossomos. Praticamente não foram detectadas interações genótipos por ambientes para estes dois caracteres.

Para o caráter florescimento masculino foram detectadas pequenas porcentagens de marcadores com significância para os efeitos aditivos, 
dominantes e epistáticos, sendo que a maior parte dos coeficientes dos efeitos dominantes foi negativa. Entretanto, foi encontrado grande porcentagem de marcadores com efeitos da interação contrastes por ambientes significativos, indicando que este caráter foi muito influenciado pelo ambiente. É necessário enfatizar que o material genético avaliado por estes autores foi originado de clima temperado.

As análises realizadas por Stuber et al. (1992) não puderam separar os efeitos aditivos e dominantes referentes a cada marcador porque foram desenvolvidas separadamente, ou seja, foi realizada uma análise para cada retrocruzamento. Por isso, a detecção de QTLs para todos os caracteres realizada por esses autores sofreu limitações, como por exemplo, para produção de grãos, em que não foi possível detectar QTLs no cromossomo 6, para um retrocruzamento. Como demonstrado por Cockerham \& Zeng (1996), as estimativas dos efeitos aditivos, dominantes e epistáticos, são obtidas através de contrastes ortogonais realizados entre os genótipos do marcador envolvendo os dois retrocruzamentos. Demonstraram também que, quando existe mais de um QTL ligado ao marcador, pode haver cancelamento ou agregação de valores dos efeitos. Além do mais, os efeitos epistáticos podem influenciar os efeitos aditivos e dominantes de forma imprevisível, aumentando ou diminuindo seus valores.

A diferença entre as médias dos retrocruzamentos das linhagens B73 e Mo17, para o caráter produção de grãos, foi positiva a favor da linhagem B73. Pelas deduções do delineamento III e na ausência de epistasia, é esperado que esse resultado seja o somatório dos efeitos aditivos de todos os locos. É esperado também, que sejam positivos os valores dos coeficientes $\beta_{1}$ obtidos da análise de marcadores pelo delineamento III, visto que os alelos da linhagem B73 foram designados como os alelos com efeitos aditivos favoráveis. Isto foi verificado pelos resultados obtidos para este caráter, em que os coeficientes $\beta_{1}$ significativos e positivos parecem estar concentrados nos cromossomos 3 e 4 . A ausência de marcadores com significância para esse coeficiente $\beta_{1}$ nos demais cromossomos pode ser devido ao cancelamento de seus efeitos.

Dentre as possíveis explicações para a heterose está a dominância de alelos favoráveis. Os resultados obtidos para a maioria dos caracteres analisados por Cockerham \& Zeng (1996) podem confirmar esta hipótese, uma vez que a maior parte dos coeficientes $\beta_{3}$ apresentaram valores positivos. Os 
marcadores em cada cromossomo não são independentes e vários marcadores adjacentes podem detectar o mesmo QTL. Baseado na distância genética de cada cromossomo, na mudança de sinal dos coeficientes $\beta_{1}$ entre os marcadores adjacentes e na significância para os efeitos epistáticos de alguns marcadores em cada cromossomo, existe evidências suficientes para sugerir a presença de vários QTLs em muitos cromossomos para todos os caracteres. Quando vários QTLs estão ligados, existe a possibilidade de cancelamento dos efeitos aditivos e agregação dos efeitos dominantes, podendo ser observada a presença da pseudo-sobredominância em alguns locos em análises de marcas simples, como é o caso do delineamento III. A dominância favorável expressa pelos coeficentes $\beta_{3}$, em conjunto com o cancelamento dos efeitos aditivos, podem ser responsáveis pelo grau médio de dominância de 1,96 para produção de grãos detectado pela análise de variância.

Uma outra explicação para a heterose é a ligação de complexos epistáticos favoráveis nas linhagens parentais. O trabalho de Cockerham \& Zeng (1996) detectou a possibilidade de existir substanciais efeitos epistáticos de QTLs ligados. Então, apesar desta análise não detectar efeitos epistáticos de QTLs não ligados, a importância da epistasia não pode ser ignorada para os caracteres avaliados por estes autores. 


\section{MATERIAL E MÉTODOS}

\subsection{Material genético}

Foram utilizadas, para as avaliações fenotípicas, 250 progênies $F_{2: 3}$ retrocruzadas para ambos os parentais, totalizando 500 tratamentos. Para a genotipagem foram utilizadas as 250 plantas $F_{2}$ que deram origem às progênies $\mathrm{F}_{2: 3}$ retrocruzadas.

Para a obtenção das progênies foram selecionadas duas linhagens contrastantes para o caráter produção de grãos, uma da população IG-1 (L-0805F) e outra da população BR106 (L-14-04B). As populações IG-1 e BR-106, apresentam elevadas magnitudes de heterose em seu cruzamento, estando alocadas em grupos heteróticos distintos (Souza Júnior et al., 1993). A linhagem L-08-05F (S7) possui grãos duros de coloração alaranjada e a linhagem L-14-04B (S5) apresenta grãos dentados de coloração amarela.

A partir da autofecundação das plantas $F_{1}$, oriundas do cruzamento L08-05F X L-14-04B, foi obtida a população $F_{2}$. As plantas $F_{2}$ foram autofecundadas, dando origem às progênies $F_{2: 3}$. Duzentos e cinqüenta progênies $F_{2: 3}$ foram retrocruzadas com ambas as linhagens parentais gerando, de cada progênie $F_{2: 3}$, dois tipos de progênies retrocruzadas. Essas 500 progênies, $250 \mathrm{RCP}_{1}$ e $250 \mathrm{RCP}$, foram aquelas utilizadas para a obtenção dos dados fenotípicos.

Para a realização dos retrocruzamentos foi feito a escolha da área e o planejamento da época de semeio das progênies objetivando o isolamento reprodutivo com relação a outros materiais genéticos. Essa área foi localizada dentro da Estação Experimental do Departamento de Genética. Foram semeadas 30 sementes de cada progênie $F_{2: 3}$ em uma linha de $6 \mathrm{~m}$ de comprimento, com $0,80 \mathrm{~m}$ entre linhas e $0,20 \mathrm{~m}$ entre sementes. Também foi 
realizado o semeio da linhagem parental doadora de pólen na proporção de 1 linha de linhagem para 2 linhas de progênies. Para que as plantas da linhagem parental apresentassem liberação de pólen durante todo o período reprodutivo das progênies $F_{2: 3}$, seu semeio foi realizado em três épocas: 5 dias antes, no dia e 5 dias após o semeio das progênies. A polinização foi realizada livremente pela linhagem doadora de pólen, sendo os pendões das progênies $F_{2: 3}$ retirados manualmente antes que começassem a liberar pólen. Foram colhidas todas as espigas de cada progênie conjuntamente, isto é, todas as espigas de uma progênie foram colocadas em uma mesma embalagem. Após a debulha, essas sementes foram utilizadas para a instalação dos experimentos. Todo o procedimento descrito acima foi realizado duas vezes, sendo uma para cada linhagem parental.

\subsection{Métodos}

\subsubsection{Marcadores moleculares}

\subsubsection{Extração do DNA genômico}

Todas as 250 plantas $F_{2}$, que deram origem às progênies $F_{2: 3}$, tiveram uma ou duas folhas coletadas, sendo acondicionadas em saquinhos de sombrite, congeladas em nitrogênio líquido e armazenadas em congelador com temperatura de $-70^{\circ} \mathrm{C}$, até que sua liofilização fosse realizada. Após a liofilização, as amostras foram moídas e finalmente armazenadas, em frascos próprios, em congelador a $-20^{\circ} \mathrm{C}$. O protocolo de extração de DNA foi baseado na metodologia desenvolvida por Hoisington et al. (1994), utilizando-se $50 \mathrm{mg}$ de tecido liofilizado e moído, tampão de extração CTAB ("Mixed alkyltrimethylammonium bromide"), e duas extrações sucessivas em clorofórmio/álcool isoamílico (24:1). O DNA de cada amostra foi submetido a uma extração final com fenol para garantir maior pureza do produto final. 


\subsubsection{Condições de amplificação e genotipagem}

O programa para amplificação do DNA utilizado foi desenvolvido por Don et al. (1991) para amplificação de microssatélites em milho, denominado de Touchdown PCR, com algumas modificações. Seu objetivo é a amplificação do DNA com diferentes temperaturas de anelamento. Assim, a temperatura de anelamento decresce $1^{\circ} \mathrm{C}$ a cada dois ciclos, de $65^{\circ} \mathrm{C}$ a $55^{\circ} \mathrm{C}$, na qual realizamse 20 ciclos. O programa é finalizado mantendo-se a temperatura de anelamento em $55^{\circ} \mathrm{C}$ por mais 20 ciclos. As temperaturas de desnaturação e extensão são $94^{\circ} \mathrm{C}$ e $72^{\circ} \mathrm{C}$, respectivamente.

A genotipagem foi feita em todas as 250 plantas $F_{2}$ que tiveram seu DNA extraído. Foram utilizados 140 pares de primers microssatélites. Estes foram obtidos após a realização de testes de amplificação/polimorfismo para 859 pares de primers. As sequências de nucleotídeos para a síntese dos primers foram obtidas na página PCR Primer Pairs for Microsatellites da Universidade de Missouri-Columbia (http://nucleus.agron.missouri.edu/cgi-bin/ssr_bin.pl).

Os resultados das amplificações foram visualizados após eletroforese em gel de agarose/metaphor 1:1 a 4\%, utilizando tampão TBE (Tris/Ácido bórico/EDTA) 0,5x. Essa eletroforese foi realizada a $170 \mathrm{v}$, e pelo tempo de $1: 20 \mathrm{~h}$ a 2:00 h. Em seguida, o gel foi corado em banho com brometo de etídeo $(0,5 \mu \mathrm{g} / \mathrm{ml})$ por $20 \mathrm{~min}$, descorado em água destilada por 10 minutos, visualizado e fotografado com filme e câmera Polaroid sob luz ultra-violeta.

\subsubsection{Construção do mapa genético}

Para a construção do mapa genético, foram utilizados os marcadores que não apresentavam desvios significativos de segregação genotípica. O nível de significância estabelecido para esses desvios (1:2:1) foi de $P \leq 0,05$, aplicando-se a correção de Bonferroni (Holm, 1979). Como citado por Province (2001), essa correção consiste em determinar o valor do nível de significância individual $\left(\alpha_{E}\right)$, que proporcionará o nível de significância conjunto $\left(\alpha_{T}\right)$ desejado, dado por: 


$$
\alpha_{T}=-\exp \left(\frac{\ln \left(1-\alpha_{E}\right)}{M}\right)+1,
$$

em que $M$ é o número de testes simples realizados.

Para usar a correção de Bonferroni, assumiu-se que os $M$ testes foram independentes, sendo o número de testes de 179 (179 marcadores polimórficos sem problemas de visualização dos resultados). Verifica-se pela equação acima que o nível de significância diminui à medida que aumenta o número de testes realizados. Por exemplo, com 2 testes e com $\alpha_{E}=0,05 \mathrm{em}$ cada um, o nível de significância conjunto desejado será $\alpha_{T}=0.025320566$; com 100 testes 0.000512801 ; e com 179 testes 0,000286514 (valor de quiquadrado tabelado $=16,32$ ). Este último nível foi adotado para considerar os desvios de segregação dos marcadores, sendo analisados somente aqueles (140) que não ultrapassaram o valor do qui-quadrado tabelado de 16,32.

O mapa de ligação genético foi construído utilizando o programa Mapmaker versão 3.0 (Lincoln et al., 1992), com 140 marcadores. Para considerar os marcadores ligados dentro de cada grupo de ligação, adotou-se 0 comando group com freqüência máxima de recombinação entre dois locos de $80 \%$ e $L O D$ score de 3,0 . Um valor de $L O D$ score igual a 3 indica que a hipótese alternativa é $10^{3}$ vezes mais provável de ocorrer do que a hipótese nula. Análises de três pontos foram realizadas para determinar a ordem mais provável dos marcadores dentro de cada grupo de ligação usando os comandos "compare", para os grupos que possuíam menos de 10 marcadores. Para grupos maiores, o comando "ripple" foi usado para confirmar a ordem dos marcadores como determinada pela análise multiponto. As freqüências de recombinação entre os marcadores foram estimadas por análise multiponto e transformadas em distâncias (cM) pela função de mapeamento de Kosambi (Kosambi,1944). Foram construídos 10 grupos de ligação equivalentes aos 10 cromossomos do conjunto gamético do milho.

A informação prévia da localização dos microssatélites, disponível na página http://nucleus.agron.missouri.edu/, também foi considerada para a formação dos grupos de ligação. Nessa página, as posições dos marcadores no mapa genético foram assinaladas em Bins cromossômicos. De acordo com Gardner et al. (1993) um Bin é definido como um intervalo de aproximadamente 
$20 \mathrm{cM}$ entre dois marcadores. O genoma do milho está dividido em 100 Bin's numerados de acordo com o código $X . Y$, em que $X$ refere-se ao número do cromossomo contendo o Bin e $Y$ refere-se à localização relativa do Bin dentro do cromossomo.

\subsubsection{Execução experimental}

\subsubsection{Estabelecimento dos experimentos}

O presente trabalho constituiu, portanto, de 500 progênies retrocruzadas. Essas 500 progênies foram, então, igualmente distribuídas em cinco experimentos. Cada experimento foi constituído de 50 progênies $F_{2: 3}$ retrocruzadas para ambas as linhagens parentais, totalizando 100 progênies retrocuzadas. Os experimentos foram alocados em látices $10 \times 10 \mathrm{com}$ duas repetições.

Os experimentos, em cada ambiente, foram instalados de forma adjacente e casualizados. Cada uma das duas repetições de cada experimento foi considerada de forma independente. Como em cada ambiente foram instalados 5 experimentos com 2 repetições, 10 grupos independentes foram considerados. Foi realizado um sorteio para a ordenação desses 10 grupos dentro da área experimental de cada ambiente.

Foram utilizados seis ambientes para a instalação dos experimentos. Foi considerado como ambiente cada combinação local $x$ ano agrícola $x$ época de semeadura. Os locais foram: Estação Experimental do Departamento de Genética (E.E. LGN), Estação Experimental Caterpillar (E.E. Cat) e Estação Experimental Areão (E.E. Areão). As três Estações Experimentais pertencem à Escola Superior de Agricultura "Luiz de Queiroz" / USP e estão localizadas no município de Piracicaba, SP. Os anos agrícolas foram 1999/2000 e 2000/2001. Assim, os experimentos instalados na E.E. LGN no ano 1999/2000 foram designados como ambiente 1. Todos os demais ambientes foram avaliados no ano agrícola 2000/2001, sendo, ambiente 2: E.E. LGN 1a época de semeio; ambiente 3: E.E. LGN 2 a época de semeio; ambiente 4: E.E. Areão; ambiente 5: E.E. Caterpillar; e ambiente 6: E.E. LGN 3ª época de semeio. 
Cada parcela experimental constituiu-se de uma linha de $4,00 \mathrm{~m}$ de comprimento por $0.80 \mathrm{~m}$ de espaçamento entre linhas, com 0,20 m entre plantas. Foram semeadas 40 sementes em cada parcela e feito o desbaste após 25 a 30 dias da semeadura para manter 20 plantas por parcela. Dessa forma, o estande ideal foi de 62.500 plantas por hectare.

\subsubsection{Caracteres avaliados e analisados}

Os caracteres analisados foram florescimento masculino e feminino, intervalo de florescimento, número de folhas acima da primeira espiga, altura da planta, altura da espiga, posição relativa da espiga, prolificidade, produção de grãos e teor de umidade nos grãos. Todos esses caracteres foram avaliados da seguinte maneira:

Florescimento feminino (FF): número de dias da semeadura até o florescimento feminino de $50 \%$ das plantas da parcela;

Florescimento masculino (FM): número de dias da semeadura até 0 florescimento masculino de $50 \%$ das plantas da parcela;

Intervalo de florescimento (IF): correspondeu à diferença entre os dias de florescimento masculino e florescimento feminino (FM-FF);

Altura de planta (AP): altura de cinco plantas competitivas, medida do nível do solo ao nó da inserção da folha bandeira $\left(\mathrm{cm} \mathrm{planta}^{-1}\right)$;

Altura de espiga (AE): altura da espiga de cinco plantas competitivas, medida do nível do solo ao nó da inserção da primeira espiga ( $\left.\mathrm{cm}_{\text {planta }}{ }^{-1}\right)$;

Posição relativa da espiga (PRE): correspondeu, em cada parcela, ao quociente entre a altura média da espiga e a altura média da planta (AE/AP);

Número de folhas acima da espiga superior (NF): número de folhas situadas entre a primeira espiga (superior) e o pendão, tomada de cinco plantas competitivas em cada parcela (NF planta ${ }^{-1}$ );

Prolificidade (PRO): representou, para cada parcela, o quociente entre 0 número total de espigas produzidas e o número total de plantas (estande) de cada parcela. Os dados obtidos foram corrigidos para o estande médio através do método de correção por covariância; 
Produção de grãos corrigida (PG): peso de grãos (PEG) da parcela dividido pelo número total de plantas da parcela e corrigido para $15 \%$ de teor de umidade nos grãos. Posteriormente, também foi feita uma correção para o estande médio através do método de correção por covariância;

Teor de umidade nos grãos (UM): teor de umidade tomado de uma amostra de grãos de cada parcela, utilizando o determinador eletrônico Dickey-John.

Todos os caracteres acima foram avaliados em seis ambientes, com exceção dos caracteres florescimento feminino, florescimento masculino, e o caráter adimensional relacionado, intervalo de florescimento, que não foram avaliados no ambiente 1 . Os caracteres AP, AE e NF foram analisados tomando-se as médias das medições de cada parcela.

\subsection{Análises estatísticas}

Todas as análises foram realizadas utilizando o procedimento PROC GLM do programa SAS (Statistical Analysis System, SAS, 1999) e obedecendo ao modelo proposto por Comstock e Robinson (1952). As análises de variância foram realizadas individualmente para os cinco experimentos de cada ambiente. Em seguida, foi feita uma análise agrupada para cada ambiente. Posteriormente, análises conjuntas agrupadas foram realizadas, reunindo-se todos os ambientes avaliados, para cada caráter. Em todas as análises, apenas a fonte de variação linhagens parentais foi considerada como efeito fixo. Também, foram estimados os parâmetros genéticos de acordo com o modelo proposto pelo delineamento III.

As análises de covariâncias foram realizadas da mesma forma, porém, considerando-se todas as combinações possíveis entre os dez caracteres avaliados, totalizando-se, portanto, 45 combinações. As análise de correlações genéticas aditivas, genéticas e fenotípicas, foram feitas com base nessas análises de covariâncias.

Finalmente, análises envolvendo o delineamento III e os 140 marcadores microssatélites foram realizadas para os dez caracteres avaliados, utilizando-se as médias ajustadas por ambiente das 500 progênies retrocruzadas. Cada 
valor (média ajustada) foi, então, originado da média da avaliação de duas repetições para cada progênie, em cada ambiente.

\subsubsection{Modelos matemáticos}

Para cada ambiente e para os dez caracteres avaliados, as cinco análises de variância por experimento foram, portanto, realizadas. O modelo matemático para cada análise individual, foi:

$$
Y_{i m k j}=\mu+b_{j(k)}+r_{k}+p_{i}+t_{m}+p t_{i m}+\epsilon_{i m k j}
$$

em que:

$Y_{\text {imkj }}$

: observação referente à progênie i retrocruzada com a linhagem parental $\mathrm{m}$ avaliada na repetição $\mathrm{k}$ dentro do bloco j;

$\mu \quad$ : média geral do experimento;

$b_{j(k)} \quad$ : efeito do bloco $j$ dentro da repetição $k(j=1$ a 10$)$;

$r_{k} \quad$ : efeito da repetição $k(k=1,2)$;

$\mathrm{p}_{\mathrm{i}} \quad$ : efeito da progênie $\mathrm{i}(\mathrm{i}=1$ a 50$)$;

$t_{m} \quad$ : efeito da linhagem parental (testador) $m(m=1,2)$;

$\mathrm{pt}_{\mathrm{im}} \quad$ : efeito da interação da progênie i com a linhagem parental $\mathrm{m}$;

$\epsilon_{i m k j} \quad$ : resíduo associado à parcela $Y_{\text {imkj. }}$.

Em seguida, foram realizadas as análises de variância agrupadas por ambiente, cujo modelo matemático foi:

$$
Y_{i m k j l}=\mu+z_{l}+r_{k(l)}+b_{j(k l)}+p_{i(l)}+t_{m(l)}+t_{i m(l)}+\varepsilon_{i m k j l}
$$

em que:

Yimkjl :observação referente à progênie i retrocruzada com a linhagem parental $\mathrm{m}$ avaliada na repetição $\mathrm{k}$ no bloco $\mathrm{j}$ dentro do experimento I;

$z_{1} \quad$ : efeito do experimento (látice) I ( $\quad$ = 1 a 5$)$;

$r_{k(l)} \quad$ : efeito da repetição $k$ dentro do experimento $I(k=1,2)$; 
$b_{j(k l)} \quad$ : efeito do bloco $j$ dentro da repetição $k$ dentro do experimento I $(j=$ 1 a 10$)$;

$\mathrm{p}_{\mathrm{i}(\mathrm{I})} \quad$ : efeito da progênie i dentro do experimento I ( $\mathrm{i}=1$ a 250$)$

$t_{m(I)} \quad$ : efeito da linhagem parental $m$ dentro do experimento $I(m=1,2)$;

$\mathrm{tp}_{\mathrm{im}(\mathrm{l})} \quad$ : efeito da interação da progênie i com a linhagem parental $\mathrm{m}$ dentro do experimento I;

$\epsilon_{\text {imkjl }} \quad$ : resíduo associado à parcela $Y_{\text {imkjl. }}$

As análises de variâncias conjuntas e agrupadas foram realizadas após a verificação da homogeneidade das variâncias dos resíduos das análises por ambiente. O teste de homocedasticidade dos quadrados médios, apresentado por Gomes (1990) foi aplicado indicando, portanto, que havia a possibilidade de realização das análises conjuntas agrupadas. O modelo matemático para cada análise conjunta, foi:

$$
\begin{aligned}
Y_{i m k j l e}= & \mu+a_{e}+z_{l}+r_{k(l e)}+b_{j(k l e)}+p_{i(l)}+t_{m(l)}+a_{e l}+p t_{i m(l)}+p a_{i e(l)}+ \\
& +\operatorname{ta}_{m e(l)}+p \operatorname{pta}_{i m e(l)}+\epsilon_{\text {imkjle }},
\end{aligned}
$$

em que:

Yimkjle : observação referente à progênie i retrocruzada com a linhagem parental $m$ avaliada na repetição $k$ no bloco $j$ dentro do experimento I no ambiente $e$;

$\mathrm{a}_{e} \quad$ : efeito do ambiente $e(e=1$ a 6$)$;

$\mathrm{Z}_{\mathrm{l}} \quad$ : efeito do experimento I $(\mathrm{l}=1$ a 5$)$;

$\mathrm{r}_{\mathrm{k}(l e)} \quad$ : é o efeito da repetição k dentro do experimento I no ambiente $e$ (k $=1,2)$;

$b_{j(k l e)} \quad$ : efeito do bloco $\mathrm{j}$ dentro da repetição $\mathrm{k}$ dentro do experimento I no ambiente $e$ ( $\mathrm{j}=1$ a 10$)$;

$\mathrm{p}_{\mathrm{i}(\mathrm{l})} \quad$ : efeito da progênie i dentro do experimento I ( $=1$ a 250$)$;

$t_{m(l)} \quad$ :efeito da linhagem parental $m$ dentro do experimento $I(m=1,2)$;

$\mathrm{az}_{\mathrm{le}} \quad$ : efeito da interação do experimento I com o ambiente $e$;

$\mathrm{pt}_{\mathrm{im}(\mathrm{l})} \quad$ : efeito da interação da progênie i com a linhagem parental $\mathrm{m}$ dentro do experimento I; 
$\mathrm{pa}_{\mathrm{i} e(\mathrm{I})} \quad$ : efeito da interação da progênie i com o ambiente $e$ dentro do experimento I;

$\mathrm{ta}_{\mathrm{m} e(\mathrm{I})} \quad$ : efeito da interação da linhagem parental $\mathrm{m}$ com o ambiente $e$ dentro do experimento I;

ptaime (I) : efeito da interação da progênie i com a linhagem parental $\mathrm{m}$ e com o ambiente $e$ dentro do experimento I;

$\epsilon_{\text {imkjle }} \quad$ : resíduo associado à parcela $Y_{\text {imkjle }}$.

O esquema das análises de variância conjuntas agrupadas está apresentado na Tabela 3 , onde $k$ e $e$ referem-se ao número de repetições e ambientes, respectivamente.

Tabela 3. Esperanças dos quadrados médios e teste de $\mathrm{F}$ para as análises de variância conjuntas agrupadas.

\begin{tabular}{|c|c|c|c|c|}
\hline $\mathrm{FV}$ & $\mathrm{GL}$ & $\mathrm{QM}$ & $E(Q M)$ & $\mathrm{F}$ \\
\hline Ambientes (E) & $e-1$ & & & \\
\hline Experimentos (Exp) & $\mid-1$ & & & \\
\hline$E X \operatorname{Exp}$ & $(e-1)(I-1)$ & & & \\
\hline Repetições/Exp/E & $e l(\mathrm{k}-1)$ & & & \\
\hline Blocos/E/Rep/Exp & $e \mathrm{kl}(\mathrm{j}-1)$ & & & \\
\hline Linhagens $(T) /$ Exp & I & & & \\
\hline$(T \times E) / \operatorname{Exp}$ & $I(e-1)$ & & & \\
\hline Progênies (P)/Exp & $I(i-1)$ & $\mathrm{QM}_{P}$ & $\sigma_{R}^{2}+2 k \sigma_{P E+}^{2} 2 k e \sigma_{P}^{2}$ & $\mathrm{QM}_{P} / \mathrm{QM}_{P E}$ \\
\hline$(\mathrm{P} \times \mathrm{T}) / \mathrm{Exp}$ & $I(i-1)$ & $\mathrm{QM}_{P T}$ & $\sigma_{R}^{2}+k \sigma_{P T E}^{2}+k e \sigma_{P T}^{2}$ & $\mathrm{QM}_{P T} / \mathrm{QM}_{P T E}$ \\
\hline$(\mathrm{P} \times \mathrm{E}) / \operatorname{Exp}$ & $(e-1) \mid(\mathrm{i}-1)$ & $\mathrm{QM}_{P E}$ & $\sigma_{R}^{2}+2 k \sigma_{P E}^{2}$ & $\mathrm{QM}_{P E} / \mathrm{QM}_{R}$ \\
\hline$(P \times T \times E) / E x p$ & $(e-1) I(\mathrm{i}-1)$ & $\mathrm{QM}_{P T E}$ & $\sigma_{R}^{2}+k \sigma_{P T E}^{2}$ & $\mathrm{QM}_{P T E} / \mathrm{QM}_{R}$ \\
\hline Resíduo & $e l(2 i k-2 i-k j+1)$ & $\mathrm{QM}_{R}$ & $\sigma_{R}^{2}$ & \\
\hline Total & 2 elik-1 & & & \\
\hline
\end{tabular}




\subsubsection{Estimativas dos parâmetros genéticos}

Os estimadores dos componentes de variância para os dez caracteres avaliados a partir da análise de variância conjunta e agrupada (Tabela 3), obtidos de acordo com os procedimentos descritos por Comstock e Robinson (1952) e por Cockerham e Zeng (1996), foram:

Variância de progênies $\left(\hat{\sigma}_{P}^{2}\right)$ :

$$
\hat{\sigma}_{P}^{2}=\frac{Q M_{P}-Q M_{P E}}{2 k e} ;
$$

Variância da interação de progênies com ambientes $\left(\hat{\sigma}_{P E}^{2}\right)$ :

$$
\hat{\sigma}_{P E}^{2}=\frac{Q M_{P E}-Q M_{R}}{2 k}
$$

Variância da interação progênies com linhagens parentais $\left(\hat{\sigma}_{P T}^{2}\right)$ :

$$
\hat{\sigma}_{P T}^{2}=\frac{Q M_{P T}-Q M_{P T E}}{k e} ;
$$

Variância da interação de progênies com linhagens parentais e com ambientes $\left(\hat{\sigma}_{P T E}^{2}\right)$ :

$$
\hat{\sigma}_{P T E}^{2}=\frac{Q M_{P T E}-Q M_{R}}{k} ;
$$

Variância do resíduo $\left(\hat{\sigma}_{R}^{2}\right)$ :

$$
\hat{\sigma}_{R}^{2}=\mathrm{QM}_{\mathrm{R}}
$$

As estimativas da variância fenotípica e da herdabilidade, para os dez caracteres avaliados a partir das análises de variância conjuntas agrupadas, foram obtidos dos estimadores destes parâmetros para progênies de meiosirmãos, segundo procedimento semelhante ao adotado por Wolf et al. (2000). 
Dessa forma, o estimador da variância fenotípica de médias de progênies de meios-irmãos $\left(\hat{\sigma}_{\bar{F}}^{2}\right)$ foi:

$$
\hat{\sigma}_{\bar{F}}^{2}=\frac{Q M p}{2 k e} \quad \text { ou } \quad \hat{\sigma}_{\bar{F}}^{2}=\frac{\hat{\sigma}_{R}^{2}}{2 k e}+\frac{\hat{\sigma}_{P A}^{2}}{2 e}+\hat{\sigma}_{P}^{2}
$$

o estimador da herdabilidade média de progênies de meios-irmãos $\left(\hat{h}_{\bar{X}}^{2}\right)$ foi:

$$
\hat{h}_{\bar{X}}^{2}=\hat{\sigma}_{P}^{2} / \hat{\sigma}_{\bar{F}}^{2}
$$

A partir das estimativas de $\hat{\sigma}_{P}^{2}, \hat{\sigma}_{P E}^{2}, \hat{\sigma}_{P T}^{2}$ e $\hat{\sigma}_{P T E}^{2}$, estimou-se as variâncias genéticas aditivas e dominantes e suas respectivas interações com o ambiente, segundo Comstock \& Robinson (1952):

$$
\begin{array}{lll}
\hat{\sigma}_{A}^{2}=4 \hat{\sigma}_{P}^{2}, & \hat{\sigma}_{D}^{2}=\hat{\sigma}_{P T}^{2}, & \hat{\sigma}_{G}^{2}=\hat{\sigma}_{A}^{2}+\hat{\sigma}_{D}^{2}, \\
\hat{\sigma}_{A E}^{2}=4 \hat{\sigma}_{P E}^{2}, & \hat{\sigma}_{D E}^{2}=\hat{\sigma}_{P T E}^{2}, & \hat{\sigma}_{G E}^{2}=\hat{\sigma}_{A E}^{2}+\hat{\sigma}_{D E}^{2} .
\end{array}
$$

O grau médio de dominância foi estimado para cada caráter por:

$$
G \hat{M D}=\left(2 \hat{\sigma}_{D}^{2} / \hat{\sigma}_{A}^{2}\right)^{1 / 2}
$$

\subsubsection{Análises de covariância e estimativas dos coeficientes de correlação}

Coeficientes de correlação genética aditiva, de correlação genética e de correlação fenotípica foram estimados para as 45 combinações possíveis entre os dez caracteres avaliados, a partir da análise conjunta e agrupada de covariância.

Considerando-se dois caracteres ( $x$ e $y$ ), após as respectivas análises de variância conjuntas agrupadas, uma análise de variância conjunta agrupada correspondente à soma de tais caracteres $(s=x+y)$ foi realizada. Cada análise de variância referente à soma de dois caracteres seguiu exatamente a mesma estrutura apresentada pelas análises de variâncias para cada caráter, 
individualmente, segundo a metodologia proposta por Vencovsky \& Barriga (1992). Assim, uma análise de covariância conjunta agrupada foi realizada para cada par de caracteres, cuja estrutura é semelhante à estrutura da análise de variância conjunta agrupada apresentada na Tabela 3 , em que os quadrados médios (QM) são substituídos pelos produtos médios (PM) e as variâncias $\left(\sigma^{2}\right)$ são substituídas pelas covariâncias (COV).

Os produtos médios das fontes de covariação foram, portanto, calculados da seguinte maneira:

$$
\mathrm{PM}_{\mathrm{FC} x \mathrm{y}}=\left(\frac{1}{2}\right)\left(\mathrm{QM}_{\mathrm{FVs}}-\mathrm{QM}_{\mathrm{FV} \mathrm{x}}-\mathrm{QM}_{\mathrm{FVy}}\right)
$$

em que $x$ e $y$ referem-se aos caracteres considerados; $s$ refere-se à soma dos dois caracteres; $\mathrm{PM}_{\mathrm{FC} x y}$ é o produto médio da fonte de covariação considerada dos caracteres x e y e $\mathrm{QM}_{\mathrm{FV} x}$ e $\mathrm{QM}_{\mathrm{FV} y} \mathrm{QM}_{\mathrm{FV}}$, são os quadrados médios da fonte de variação equivalente dos caracteres $x$ e $y$ e da soma (s), respectivamente.

Dessa forma, foram calculados os produtos médios das progênies (PMPxy), da interação das progênies com os ambientes (PMPExy), das interações das progênies com as linhagens parentais (PMPTxy), das interações das progênies com as linhagens parentais com os ambientes (PMPTExy) e do resíduo $\left(\mathrm{PM}_{\mathrm{Rxy}}\right)$, entre os caracteres $x$ e $y$.

Em seguida, a covariância aditiva $\left(C \hat{O} V_{A v}\right)$, a covariância dominante ( $C \hat{O} V_{D_{\mathrm{Dxy}}}$ ), a covariância genética ( $\left.C \hat{O} V_{G \mathrm{~Gy}}\right)$, e a covariância fenotípica ( $\left.C \hat{O} V_{\bar{F}_{x y}}\right)$ entre os caracteres $x$ e $y$ foram estimadas da seguinte forma:

$$
\begin{aligned}
& C \hat{O} V_{A y y}=4 C \hat{O} V_{P x y}=4\left(P M_{P x y}-P M_{P E x y}\right) / 2 k e, \\
& C \hat{O} V_{D x y}=C \hat{O} V_{P T y}=\left(P M_{P T x y}-P M_{P T E x y}\right) / k e, \\
& C \hat{O} V_{G x y}=C \hat{O} V_{A y y}+C \hat{O} V_{D y}, \\
& C \hat{O} V_{P E Y}=\left(P M_{P E x y}-P M_{R x y}\right) / 2 k,
\end{aligned}
$$




$$
\begin{aligned}
& C \hat{O} V_{R x y}=P M_{R x y}, \\
& C \hat{O} V_{\overline{F x y}}=P M_{\mathrm{Pxy}} / 2 \mathrm{ke},
\end{aligned}
$$

em que $C \hat{O} V_{P y y}$, $C \hat{O} V_{P T Y}$, $C \hat{O} V_{P E Y}$ e $C \hat{O} V_{R y}$ referem-se à covariância de progênies, covariância da interação de progênies com linhagens parentais, covariância da interação de progênies com ambientes e covariância do resíduo experimental, respectivamente.

Os coeficientes de correlação aditiva $\left(r_{A \mathrm{xy}}\right)$, os coeficientes de correlação genética $\left(r_{G}\right.$ xy $)$ e os coeficientes de correlação fenotípica $\left(r_{\bar{F} \times y}\right)$ entre os caracteres $x$ e $y$ foram estimados:

$$
\begin{aligned}
& \hat{r}_{A x y}=C \hat{O} V_{A x y} / \sqrt{\hat{\sigma}_{A x}^{2} \hat{\sigma}_{A y}^{2}}, \\
& \hat{r}_{G x y}=C \hat{O} V_{G x y} / \sqrt{\hat{\sigma}_{G x}^{2} \hat{\sigma}_{G y}^{2}} \mathrm{e} \\
& \hat{r}_{\overline{F x y}}=C \hat{O} V_{\overline{F x y}} / \sqrt{\hat{\sigma}_{\bar{F} x}^{2} \hat{\sigma}_{\overline{F y}}^{2}},
\end{aligned}
$$

em que $\hat{\sigma}_{A}^{2}, \hat{\sigma}_{G}^{2}$ e $\hat{\sigma}_{\bar{F}}^{2}$ referem-se às estimativas das variâncias aditiva, genética e fenotípica, respectivamente.

\subsubsection{Precisão das estimativas dos parâmetros genéticos}

As estimativas dos intervalos de confiança associados às variâncias genéticas de progênies $\left(\hat{\sigma}_{P}^{2}\right)$, às variâncias das interações de progênies com linhagens parentais $\left(\hat{\sigma}_{P T}^{2}\right)$, às variâncias das interações de progênies com ambientes $\left(\hat{\sigma}_{P E}^{2}\right)$, às variâncias das interações de progênies com linhagens parentais com ambientes $\left(\hat{\sigma}_{P T E}^{2}\right)$ e às variâncias dos resíduos experimentais $\left(\hat{\sigma}_{R}^{2}\right)$ foram calculadas de acordo com as expressões sugeridas por Barbin (1993). Dessa forma:

$$
\mathrm{IC}=\mathrm{P}\left[\frac{n t \sigma^{2}}{\chi_{n: 0,075}^{2}} \leq \sigma^{2} \leq \frac{n t \sigma^{2}}{\chi_{n: 0,025}^{2}}\right]=0,95
$$


em que $\sigma^{2}$ refere-se à variância genética de progênies, $\sigma_{P T}^{2}, \sigma_{P E}^{2}, \sigma_{P T E}^{2}$ ou à $\sigma_{R}^{2} ; \chi^{2}$ refere-se ao valor de qui-quadrado tabelado e $n t$ refere-se ao grau de liberdade associado à estimativa da variância genética do respectivo parâmetro genético. O valor de $n t$ foi obtido através da expressão de Satterthwaite, que é uma fórmula empregada para calcular o número de graus de liberdade associados a uma estimativa de variância obtida da combinação linear de dois quadrados médios referentes a duas fontes de variação com números de graus de liberdade conhecidos (Barbin, 1993). Para o cálculo do intervalo de confiança associado à variância do resíduo experimental, o $n t$ foi substituído pelo seu número de graus de liberdade.

As estimativas dos intervalos de confiança (IC) associados aos coeficientes de herdabilidade $\left(\hat{h}_{\bar{x}}^{2}\right)$ foram calculadas de acordo com a expressão sugerida por Knapp et al. (1985):

$$
\mathrm{IC}=\mathrm{P}\left\{1-\frac{1}{\left[\left(\frac{Q M_{P}}{Q M_{P E}}\right) F_{(0,975): G L_{P} ; G L_{P E}}\right]} \leq \hat{h}_{\bar{x}}^{2} \leq 1-\frac{1}{\left[\left(\frac{Q M_{P}}{Q M_{P E}}\right) F_{(0,025): G L_{P} ; G L_{P E}}\right]}\right\}=0,95
$$

em que $\mathrm{GL}_{P}$ refere-se ao grau de liberdade das progênies, $G L_{P E}$ refere-se ao grau de liberdade das interações das progênies com os ambientes e $F$ referese ao valor $F$ tabelado.

Para a correlação fenotípica de médias de progênies, a significância dos coeficientes foi verificada diretamente em tabela apropriada - Significant values of $r$ and $R$ (Steel \& Torrie, 1980) -, com (n-2) graus de liberdade, em que $n$ representa o conjunto de pares de dados (250). 


\subsubsection{Análise dos marcadores moleculares usando o delineamento III}

De acordo com Cockerham \& Zeng (1996) pode-se, para cada marcador utilizado, efetuar 4 contrastes ortogonais entre as médias fenotípicas das progênies retrocruzadas de acordo com o genótipo e com o retrocruzamento a que pertencem. Uma análise de variância é obtida para cada marcador em que são testados os efeitos dos contrastes e das interações desses contrastes com o ambiente. De acordo com a significância desses contrastes, pode-se inferir e quantificar seus efeitos, na ausência de epistasia, e se existe um ou mais QTLs ligado a esse marcador.

\subsubsection{Contrastes}

Os seguintes contrastes ortogonais das médias associadas aos marcadores foram obtidos:

$$
\begin{aligned}
& \mathrm{C}_{1}: \bar{X}_{M M}^{L 1}+\bar{X}_{M M}^{L 2}-\bar{X}_{m m}^{L 1}-\bar{X}_{m m}^{L 2} ; \\
& \mathrm{C}_{2}: \bar{X}_{M M}^{L 1}+\bar{X}_{M M}^{L 2}+\bar{X}_{m m}^{L 1}+\bar{X}_{m m}^{L 2}-2 \bar{X}_{M m}^{L 1}-2 \bar{X}_{M m}^{L 2} ; \\
& \mathrm{C}_{3}: \bar{X}_{M M}^{L 1}-\bar{X}_{m m}^{L 1}-\bar{X}_{M M}^{L 2}+\bar{X}_{m m}^{L 2} ; \\
& \mathrm{C}_{4}: \bar{X}_{M M}^{L 1}+\bar{X}_{m m}^{L 1}-2 \bar{X}_{M m}^{L 1}-\bar{X}_{M M}^{L 2}-\bar{X}_{m m}^{L 2}+2 \bar{X}_{M m}^{L 2},
\end{aligned}
$$

em que $\bar{X}_{M M}, \bar{X}_{M m}, \bar{X}_{m m}$ referem-se às médias de qualquer caráter quantitativo agrupadas para os genótipos $M M, M m$, e $m m$, oriundas das progênies retrocruzadas, respectivamente; e $L_{1}$ e $L_{2}$ são as linhagens parentais.

Para efeito de análise estatística, estes contrastes são transformados em coeficientes de regressão linear $\left(\beta_{c}\right)$ parciais, de uma análise de regressão múltipla. Assim, tem-se que $\beta_{c}=C_{c} / \sum_{t=1}^{6} X_{t}^{2}$, em que $X_{t}$ refere-se aos coeficientes que multiplicam os componentes dos respectivos contrastes. Dessa forma: 


$$
\beta_{1}=C_{1} / 4 ; \quad \beta_{2}=C_{2} / 12 ; \quad \beta_{3}=C_{3} / 4 \quad \text { e } \quad \beta_{4}=C_{4} / 12
$$

\subsubsection{Análises de variância individuais para cada marcador}

Uma análise de variância foi construída para cada marcador, sendo que as fontes de variação são derivadas dos contrastes entre as médias fenotípicas de cada genótipo dentro de cada retrocruzamento em cada ambiente, e das interações desses contrastes com os ambientes avaliados. Os cálculos das somas de quadrados e dos quadrados médios de cada fonte de variação são apresentados a seguir.

A soma de quadrados para contrastes, que possui um grau de liberdade, sendo também o quadrado médio, é calculado por:

$$
\mathrm{SQC}_{\mathrm{ijk}}=\left(\sum_{j=1}^{e} \mathrm{C}_{\mathrm{ijk}}\right)^{2} /\left[e\left(\sum_{t=1}^{6} \mathrm{X}_{\mathrm{t}}^{2}\right)\right]
$$

em que $\mathrm{SQC}_{\mathrm{ijk}}$ é a soma de quadrados do contraste $k(1,2,3$ ou 4) para o marcador $i$ em todos os $j$ ambientes; $j$ refere-se a ambientes (1 a 6 ); $e$ é o número de ambientes e $\sum_{t=1}^{6} X_{t}^{2}$ refere-se à soma de quadrados dos coeficientes que multiplicam os componentes do respectivo contraste.

A soma de quadrados para as interações dos contrastes com os ambientes é calculada por:

$$
\mathrm{SQC}_{\mathrm{ijk}+e}=\left[\sum_{j=1}^{e}\left(\mathrm{C}_{\mathrm{ijk}}\right)^{2} / \sum_{i=1}^{6} \mathrm{X}_{\mathrm{t}}^{2}\right]-\mathrm{SQC}_{\mathrm{ijk}}
$$

em que $\mathrm{C}_{\mathrm{ijk}+e}$ é o contraste $\mathrm{k}$ para o marcador i para os $e$ ambientes. Essa soma de quadrados possui $(e-1)$ graus de liberdade. Então:

$$
\mathrm{QMC}_{\mathrm{ijk}+e}=\mathrm{SQC}_{\mathrm{ijk}+e} /(e-1) .
$$

Para calcular a soma de quadrados do resíduo, usa-se a variação entre as observações fenotípicas para cada genótipo dentro de cada marcador, 
dentro de cada retrocruzamento e dentro de cada ambiente. Para melhor entendimento, será primeiro efetuado o cálculo para um genótipo (MM) de um marcador, considerando apenas um retrocruzamento e um ambiente:

$$
\mathrm{SQR}_{(\mathrm{MM}) t e}=\sum_{s=1}^{S} \bar{Y}_{s}^{2}-\left[\left(\sum_{s=1}^{S} \bar{Y}_{s}\right)^{2} / S\right]
$$

em que $\mathrm{SQR}_{(\mathrm{MM}) t e}$ é a soma de quadrados "parcial" do resíduo para o genótipo $M M$, dentro do retrocruzamento $t$, dentro do ambiente $e ; \bar{Y}_{s}$ é o valor fenotípico médio obtido para a progênie da planta $s$ que apresenta o genótipo $M M$; e $S$ refere-se ao número de plantas genotipadas (que apresentam, nesse caso, o genótipo $M M$ ).

Finalmente, a soma de quadrados do resíduo é obtida pelo somatório de todas as $\mathrm{SQR}_{\mathrm{gte}}$, isto é, pelo somatório para os três (g) genótipos $(M M, M m \mathrm{e}$ $\mathrm{mm}$ ), para os dois retrocruzamentos e para todos os $e$ ambientes, dessa forma:

$$
\mathrm{SQ}_{\mathrm{Ri}}=\sum_{g=1}^{3} \sum_{t=1}^{2} \sum_{j=1}^{e} S Q_{g t e},
$$

em que $\mathrm{SQ}_{\mathrm{Ri}}$ é a soma de quadrados do resíduo para o marcador $i$. Essa soma de quadrados possui $2 e\left(S_{i}-3\right)$ graus de liberdade, sendo $S_{i}$ o número total de plantas genotipadas para o marcador i. Então:

$$
\mathrm{QM}_{\mathrm{Ri}}=\mathrm{SQ}_{\mathrm{Ri}} /\left[2 e\left(\mathrm{~S}_{\mathrm{i}}-3\right)\right] \text {. }
$$

A análise de variância, com os respectivos testes $F$ de significância é apresentada na Tabela 4.

Para exemplificação, considere os contrastes de seis ambientes como apresentado na Tabela 5.

Para o contraste 1 a soma de quadrados é:

$$
\mathrm{SQC}_{1}=\left(\mathrm{C}_{11}+\mathrm{C}_{12}+\mathrm{C}_{13}+\mathrm{C}_{14}+\mathrm{C}_{15}+\mathrm{C}_{16}\right)^{2} /(6 \times 4)
$$


seguindo-se o mesmo procedimento para o cálculo de $\mathrm{SQC}_{2}, \mathrm{SQC}_{3}$ e $\mathrm{SQC}_{4}$. A soma de quadrados da interação contraste 1 por ambientes $\left(C_{1}+E\right)$ é:

$$
S Q C_{1+E}=\left\{\left[\left(C_{11}\right)^{2}+\left(C_{12}\right)^{2}+\left(C_{13}\right)^{2}+\left(C_{14}\right)^{2}+\left(C_{15}\right)^{2}+\left(C_{16}\right)^{2}\right] / 4\right\}-S Q C_{1}
$$

Tabela 4. Análise de variância para o marcador i, segundo o delineamento III (Cockerham \& Zeng, 1996).

\begin{tabular}{|c|c|c|c|c|}
\hline $\mathrm{FV}$ & $\mathrm{GL}^{(1)}$ & QM & $E(Q M)^{(2)}$ & $\mathrm{F}$ \\
\hline$\overline{\mathrm{C}_{1}}$ & 1 & $\mathrm{QM}_{1}$ & $\sigma_{i}^{2} / S_{i 1}+4 \sigma_{\beta_{i 1 E}}^{2}+4 e \beta_{i 1}^{2}$ & $\mathrm{QM}_{1} / \mathrm{QM}_{1 \mathrm{E}}$ \\
\hline $\mathrm{C}_{2}$ & 1 & $\mathrm{QM}_{2}$ & $\sigma_{i}^{2} / S_{i 2}+12 \sigma_{\beta_{i 2 E}}^{2}+12 e \beta_{i 2}^{2}$ & $\mathrm{QM}_{2} / \mathrm{QM}_{2 \mathrm{E}}$ \\
\hline $\mathrm{C}_{3}$ & 1 & $\mathrm{QM}_{3}$ & $\sigma_{i}^{2} / S_{i 3}+4 \sigma_{\beta_{i 3 E}}^{2}+4 e \beta_{i 3}^{2}$ & $\mathrm{QM}_{3} / \mathrm{QM}_{3 \mathrm{E}}$ \\
\hline $\mathrm{C}_{4}$ & 1 & $\mathrm{QM}_{4}$ & $\sigma_{i}^{2} / S_{i 4}+12 \sigma_{\beta_{i 4 E}}^{2}+12 e \beta_{i 4}^{2}$ & $\mathrm{QM}_{4} / \mathrm{QM}_{4 \mathrm{E}}$ \\
\hline $\mathrm{C}_{1}+\mathrm{E}$ & $e-1$ & $\mathrm{QM}_{1 \mathrm{E}}$ & $\sigma_{i}^{2} / S_{i 1}+4 \sigma_{\beta_{i 1 E}}^{2}$ & $\left(\mathrm{QM}_{1 \mathrm{E}} \times \mathrm{S}_{\mathrm{i} 1}\right) / \mathrm{QM} \mathrm{R}_{\mathrm{R}}$ \\
\hline $\mathrm{C}_{2}+\mathrm{E}$ & $e-1$ & $\mathrm{QM}_{2 \mathrm{E}}$ & $\sigma_{i}^{2} / S_{i 2}+12 \sigma_{\beta_{i 2 E}}^{2}$ & $\left(Q_{2 E} \times S_{i 2}\right) / Q M_{R}$ \\
\hline $\mathrm{C}_{3}+\mathrm{E}$ & $e-1$ & $\mathrm{QM}_{3 \mathrm{E}}$ & $\sigma_{i}^{2} / S_{i 3}+4 \sigma_{\beta_{i 3 E}}^{2}$ & $\left(Q_{2 E} \times S_{i 3}\right) / Q M_{R}$ \\
\hline $\mathrm{C}_{4+} \mathrm{E}$ & $e-1$ & $\mathrm{QM}_{4 \mathrm{E}}$ & $\sigma_{i}^{2} / S_{i 4}+12 \sigma_{\beta_{i 4 E}}^{2}$ & $\left(\mathrm{QM}_{2 \mathrm{E}} \times \mathrm{S}_{\mathrm{i} 4}\right) / \mathrm{QM} \mathrm{R}$ \\
\hline Resíduo & $2 e\left(\mathrm{~S}_{\mathrm{i}}-3\right)$ & $\mathrm{QM}_{\mathrm{R}}$ & $\sigma_{i}^{2}$ & \\
\hline Total & $2 e S_{i}-1$ & & & \\
\hline
\end{tabular}

Tabela 5. Esquema representativo dos contrastes de um determinado marcador para seis ambientes.

\begin{tabular}{ccccccc}
\hline \multirow{2}{*}{ Contrastes } & \multicolumn{7}{c}{ Ambientes } \\
\cline { 2 - 7 } & $e_{1}$ & $e_{2}$ & $e_{3}$ & $e_{4}$ & $e_{5}$ & $e_{6}$ \\
\hline $\mathrm{C}_{1}$ & $\mathrm{C}_{11}$ & $\mathrm{C}_{12}$ & $\mathrm{C}_{13}$ & $\mathrm{C}_{14}$ & $\mathrm{C}_{15}$ & $\mathrm{C}_{16}$ \\
$\mathrm{C}_{2}$ & $\mathrm{C}_{21}$ & $\mathrm{C}_{22}$ & $\mathrm{C}_{23}$ & $\mathrm{C}_{24}$ & $\mathrm{C}_{25}$ & $\mathrm{C}_{26}$ \\
$\mathrm{C}_{3}$ & $\mathrm{C}_{31}$ & $\mathrm{C}_{32}$ & $\mathrm{C}_{33}$ & $\mathrm{C}_{34}$ & $\mathrm{C}_{35}$ & $\mathrm{C}_{36}$ \\
$\mathrm{C}_{4}$ & $\mathrm{C}_{41}$ & $\mathrm{C}_{42}$ & $\mathrm{C}_{43}$ & $\mathrm{C}_{44}$ & $\mathrm{C}_{45}$ & $\mathrm{C}_{46}$ \\
\hline
\end{tabular}

A mesma metodologia é adotada para o cálculo de $\mathrm{SQC}_{2+\mathrm{E}}, \mathrm{SQC}_{3+\mathrm{E}}$ e $\mathrm{SQC}_{4+\mathrm{E}}$.

Para o cálculo da soma de quadrados do resíduo, considere que todas as 250 plantas foram genotipadas com o marcador $i$, sendo obtido a seguinte distribuição genotípica: 62 plantas possuem o genótipo MM, 67 plantas 
possuem o genótipo mm e 121 plantas possuem o genótipo Mm. A soma de quadrados do genótipo $\mathrm{MM}$, dentro do retrocruzamento 1 dentro do ambiente 1 é:

$$
\mathrm{SQR}_{(\mathrm{MM}) t e}=\left[\left(\bar{Y}_{1} \mathrm{MM}\right)^{2}+\ldots+\left(\bar{Y}_{62} \mathrm{MM}\right)^{2}\right]-\left[\left(\sum_{s=1}^{62} \bar{Y} \mathrm{MM}\right)^{2} / 62\right],
$$

em que $\mathrm{SQR}_{(\mathrm{MM}) t e}$ refere-se à soma de quadrados "parcial" do resíduo considerando apenas o genótipo $\mathrm{MM}$ para o retrocruzamento 1 dentro do ambiente 1, e $\bar{Y}$ refere-se ao valor fenotípico médio da progênie retrocruzada com a linhagem parental 1.

A soma de quadrados do resíduo para o marcador i é então obtida pelo somatório das SQ "parciais" de genótipos, retrocruzamentos e ambientes é:

$$
S Q_{\mathrm{Ri}}=\sum_{g=1}^{3} \sum_{t=1}^{2} \sum_{e=1}^{6} S Q_{g t e}
$$

Finalmente, o quadrado médio do resíduo é obtido por:

$$
\mathrm{QM}_{\mathrm{Ri}}=\mathrm{SQ}_{\mathrm{Ri}} /[2 \cdot 6 \cdot(250-3)]
$$




\section{RESULTADOS E DISCUSSÃO}

\subsection{Análise geral dos resultados}

Foram utilizados 859 pares de primers para a realização de testes visando à detecção de polimorfismo. Resumindo os resultados obtidos por esses testes, 282 pares de primers não tiveram seus produtos amplificados separados em gel de agarose, 251 não tiveram polimorfismo em seus produtos amplificados, 113 não amplificaram nenhum fragmento de DNA e 213 foram polimórficos. Dentre os polimórficos, 35 não apresentaram boa visualização de bandas no gel de agarose; 19 tiveram desvios significativos na segregação 1:2:1; 19 tiveram problemas com amplificação de alelos; e 140 não tiveram nenhum problema e foram utilizados para a construção do mapa genotípico.

$O$ mapa genético foi obtido a partir de 250 plantas $F_{2}$ genotipadas com 140 marcadores microssatélites. Esse mapa apresentou 1730,10 centimorgans (cM) de extensão e, portanto, $12,40 \mathrm{cM}$ de intervalo médio entre marcadores adjacentes. O grupo de ligação do cromossomo (C) 1 foi construído com 19 marcadores e o intervalo mapeado foi de $244,30 \mathrm{cM}$, o C 2 com 19 marcadores e 210,90 cM, o C 3 com 13 marcadores e 192,50 cM, o C 4 com 19 marcadores e 177,40 cM, o C 5 com 16 marcadores e 199,50 cM, o C 6 com 12 marcadores e 162,90 cM, o C 7 com 9 marcadores e $152,70 \mathrm{cM}$, o C 8 com 11 marcadores e 171,40 cM, o C 9 com 10 marcadores e 106,50 cM e o C $10 \mathrm{com} 12$ marcadores de 112,00 cM. Pode-se notar que existem intervalos maiores de 20 cM em todos os cromossomos, porém, apenas os cromossomos 2, 4, 5 e 10 apresentaram distâncias maiores do que $40 \mathrm{cM}$ sem marcadores. Por outro lado, existem regiões com marcadores muito próximos entre si, menores do que $2 \mathrm{cM}$, em vários cromossomos (Figura 1). 


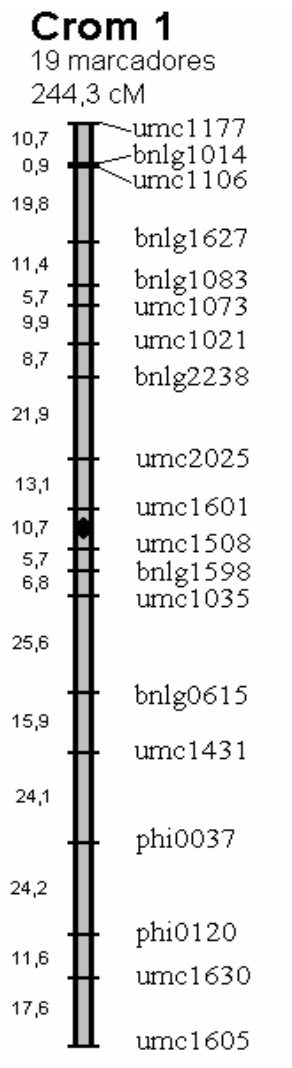

\section{Crom 6}

12 marcadores $162,9 \mathrm{cM}$

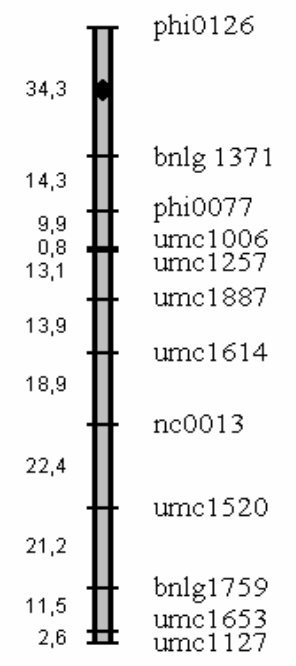

Crom 2

19 marcadores $210,9 \mathrm{cM}$

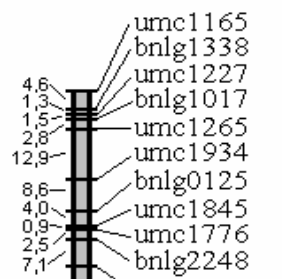

32,2 bnlg0381

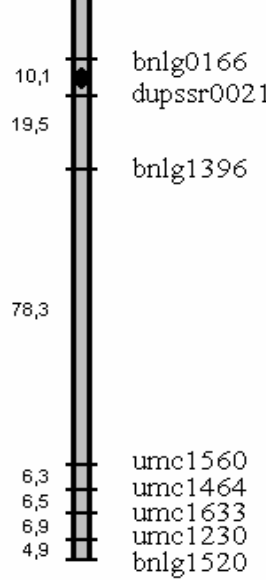

Crom 7

9 marcadores $152,7 \mathrm{cM}$

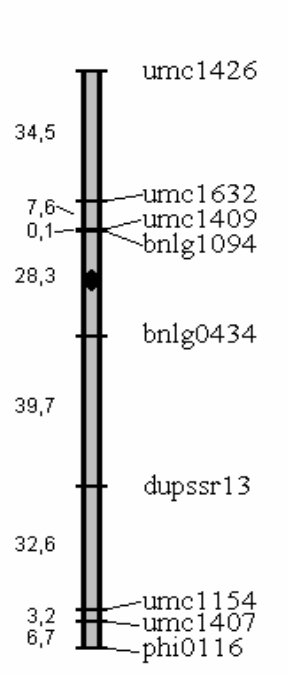

Crom 3

13 marcadores

$192,5 \mathrm{cM}$

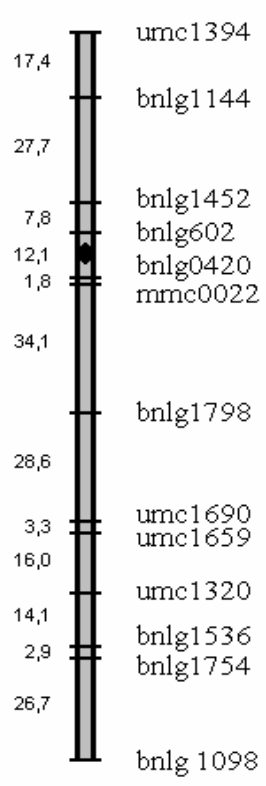

Crom 8

11 marcadores

$171,4 \mathrm{~cm}$

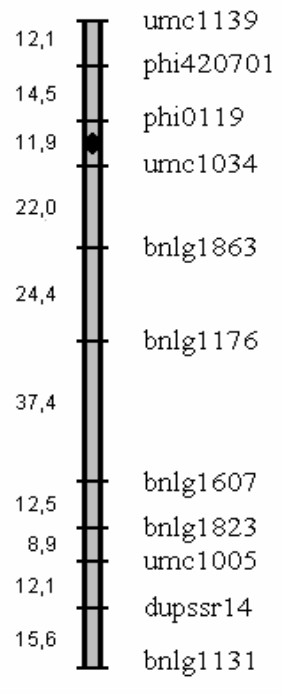

Crom 4

19 marcadores

$177,4 \mathrm{cM}$

Crom 5

16 marcadores

$199,5 \mathrm{cM}$

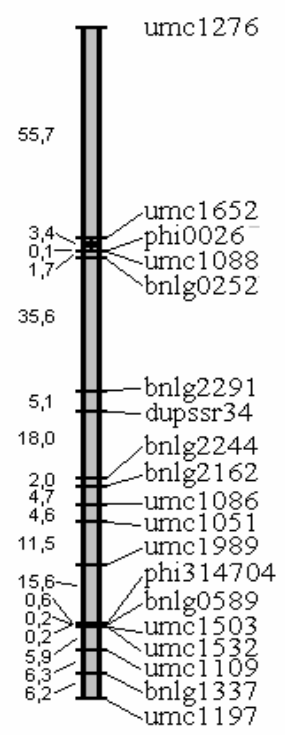

\section{Crom 9}

10 marcadores $106,5 \mathrm{~cm}$

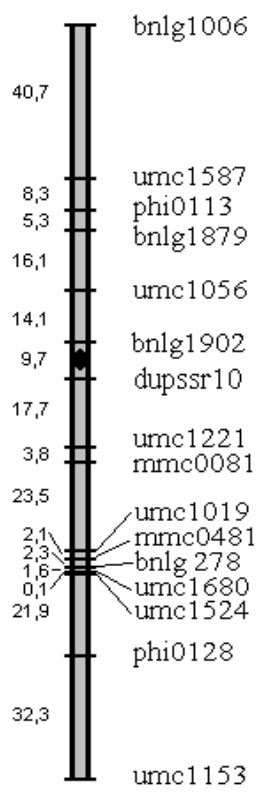

\section{Crom 10}

12 marcadores $112.0 \mathrm{~cm}$

Figura 1. Mapa genético com 140 marcadores microssatélites distribuídos nos 10 cromossomos do milho, constituído de 1730,1 centiMorgam (cM) de extensão e 12,4 cM de intervalo médio entre marcadores. Os números à esquerda do cromossomo são as distâncias em cM entre os marcadores; à direita está apresentado o nome do marcador. 
Em geral, os experimentos de campo foram conduzidos sob boas condições de temperatura, umidade e fertilidade do solo, o que permitiu a obtenção de valores médios, para todos os caracteres, com precisão adequada e com baixos valores de coeficientes de variação experimental (Tabela 6).

Para o caráter produção de grãos (PG) o intervalo de variação foi de $70,43 \mathrm{~g}_{\text {planta }}^{-1}$ a $150,60 \mathrm{~g}_{\text {planta }}{ }^{-1}$ e média geral de $116,78 \mathrm{~g}_{\text {planta }}{ }^{-1}$. A média foi considerada alta, correspondente a 7,30 ton ha ${ }^{-1}$, uma vez que se trata de progênies $\mathrm{F}_{2: 3}$ retrocruzadas. Esse fato pode ser atribuído à elevada heterose existente no cruzamento entre as linhagens parentais e às boas condições ambientais proporcionadas para o desenvolvimento das plantas (Tabela 6).

Para o caráter prolificidade (PRO) a variação foi de 0,71 espigas planta ${ }^{-1}$ a 1,38 espigas planta ${ }^{-1}$, com média de 1,09 espigas planta $^{-1}$. Para altura da espiga (AE), altura da planta (AP) e posição relativa da espiga (PRE) foram obtidos os intervalos de variação de $97,00 \mathrm{~cm}$ a $122,85 \mathrm{~cm}$, de $182,33 \mathrm{~cm}$ a $220,39 \mathrm{~cm}$ e de 0,49 a 0,59, respectivamente. As médias gerais para estes caracteres foram de $108,70 \mathrm{~cm}, 202,49 \mathrm{~cm}$ e 0,54 , respectivamente. Os caracteres relacionados ao florescimento apresentaram variação de 61,50 a 68,91 dias para florescimento feminino (FF), de 61,82 dias a 68,91 dias para florescimento masculino (FM), e $-3,25$ dias a 1,19 dias para intervalo de florescimento (IF). As médias para FF, FM e IF foram de 65,99 dias, 65,28 dias e $-0,72$ dias, respectivamente. Para número de folhas acima da primeira espiga (NF) o intervalo de variação das médias das progênies variou de 5,40 folhas planta $^{-1}$ a 6,58 folhas planta ${ }^{-1}$, com média geral de 5,97 folhas planta ${ }^{-1}$. O caráter teor de umidade nos grãos (UM) apresentou variação de 10,56\% a $11,89 \%$ e média de $11,28 \%$ (Tabela 6 ).

Pode-se notar que as progênies retrocruzadas com a linhagem L-14-04 apresentaram maiores produção de grãos, prolificidade, altura da planta e da espiga, número de dias para florescimento feminino e masculino, menor intervalo de florescimento e menor número de folhas acima da primeira espiga, do que as progênies retrocruzadas com a linhagem L08-05, evidenciando a divergência entre as linhagens parentais para estes caracteres. Este fato era esperado, visto que a linhagem L-14-04 apresenta um bom comportamento per se (Souza Júnior, 2000) ${ }^{3}$, além destes caracteres apresentarem correlação

${ }^{3}$ SOUZA JÚNIOR, C.L. (ESALQ/USP. Escola Superior de Agricultura "Luiz de Queiroz" / Universidade de São Paulo). Comunicacão nessoal. 2000. 
entre si. Os caracteres posição relativa da espiga e teor de umidade nos grãos apresentaram valores médios muito próximos entre os dois tipos de progênies retrocruzadas, evidenciando que as linhagens parentais não são divergentes em relação a estes caracteres (Tabela 6).

Os coeficientes de variação experimental, referentes às análises conjuntas e agrupadas, foram baixos de forma geral, excetuando-se o caráter intervalo de florescimento. Apesar da obtenção de baixos valores de coeficientes de variação para os caracteres florescimento masculino e feminino, $1,94 \%$ e $2,28 \%$, respectivamente, o intervalo de florescimento apresentou valor de $161,51 \%$. Essa estimativa pode ter sido influenciada pelo valor pequeno da média deste caráter $(-0,72)$. Ainda assim, esse valor é similar a valores apresentados na literatura para esse caráter (Khairallah et al., 1998). Os demais coeficientes de variação encontrados foram: $14,23 \%$ para o caráter produção de grãos, $12,97 \%$ para prolificidade, 6,39\% para altura da espiga, 4,24\% para altura da planta, 4,25\% para posição relativa da espiga, 5,19\% para número de folhas e 4,53\% para o teor de umidade nos grãos. Pode-se considerar, portanto, que os valores obtidos estão dentro do intervalo de variação daqueles relatados, concluindo, assim, que a qualidade dos experimentos realizados está dentro dos padrões aceitáveis na experimentação agronômica. Considerando o tipo de progênies avaliadas (retrocruzamentos de $F_{2: 3}$ ), a precisão experimental pode ser considerada muito boa para todos os caracteres (Tabela 6 ).

\subsubsection{Análises de variância}

Nas análises de variâncias conjuntas e agrupadas, foram detectadas diferenças altamente significativas $(P \leq 0,01)$ entre progênies para todos os caracteres avaliados, indicando que as linhagens parentais, L-14-14 e L-08-05, são contrastantes para estes caracteres, pois liberaram variabilidade genética em grande quantidade na população derivada de seu cruzamento (Tabela 6).

Todas as fontes de variação para os caracteres PG, PRO, AE, AP e PRE foram altamente significativas $(P \leq 0,01)$, exceto a interação das progênies com as linhagens parentais e com os ambientes (PxTxE) e a interação das 
progênies com ambientes (PxE) para o caráter PRO, e a interação PxTxE para o caráter PRE, que foram significativas $(P \leq 0,05)$ (Tabela 6).

Para os caracteres FF, FM, IF, NF e UM, as fontes de variação progênies (P) e a interação PxT, foram altamente significativas $(P \leq 0,01)$, exceto para $P x T$ do caráter $U M$, que foi significativa $(P \leq 0,05)$. A interação $P x E$ para os caracteres FM e NF também foi altamente significativa $(P \leq 0,01)$, enquanto que para os caracteres FF, IF e UM essa fonte de variação não foi significativa. A interação PxTxE não foi significativa para nenhum destes caracteres. Estes resultados indicam que existe interação das progênies com o ambiente para o caráter FM e NF (Tabela 7).

\subsection{Componentes de variância e correlações entre caracteres}

\subsubsection{Componentes de variância}

\subsubsection{Produção de grãos}

A estimativa da $\hat{\sigma}_{A}^{2}$ foi de $145,77\left(\mathrm{~g} \text { planta }^{-1}\right)^{2}$ sendo menor do que a estimativa da $\hat{\sigma}_{D}^{2}$, que foi de 157,51 (g planta $\left.^{-1}\right)^{2}$. Entretanto, elas não diferem estatisticamente, uma vez que o intervalo de confiança da estimativa da $\hat{\sigma}_{D}^{2}$ engloba 0 valor da estimativa da $\hat{\sigma}_{A}^{2}$. Resultados obtidos por Cockerham \& Zeng (1996), Dudley (1994), Gardner (1963), Gardner et al. (1953), Moll et al. (1964), Robinson et al. (1949) e Wolf et al. (2000) são similares aos apresentados neste trabalho, reforçando a importância dos efeitos de dominância no controle genético da produção de grãos. A estimativa da $\hat{\sigma}_{A E}^{2}$ de 77,43 (g planta $\left.)^{-1}\right)^{2}$ foi 2 vezes superior à estimativa da $\hat{\sigma}_{D E}^{2}$, que foi de $33,20 \mathrm{~g}$ planta $\left.{ }^{-1}\right)^{2}$, indicando que os efeitos aditivos apresentaram uma maior interação com ambientes do que os efeitos de dominância. Resultados apresentados por Cockerham \& Zeng (1996) e por Wolf et al. (2000) também indicaram que os efeitos aditivos interagiram mais com os ambientes do que os efeitos de dominância. A estimativa do coeficiente de herdabilidade $\left(\hat{h}^{2}\right)$, obtido ao nível de médias de progênies de meios-irmãos, foi de 0,71 , e pode ser considerada alta (Tabela 7). 
As estimativas da variância aditiva e do coeficiente de herdabilidade são importantes para se antever o sucesso de um programa de seleção. Essas duas estimativas, obtidas nesse trabalho, foram consideradas altas e podem ser devido ao bom nível de variabilidade genética entre as progênies, ao bom número de ambientes avaliados e ao baixo coeficiente de variação experimental. Como o progresso com a seleção é função do coeficiente de herdabilidade, essa população possui potencial suficiente para a obtenção de respostas expressivas com a seleção para este caráter. Ressalte-se que a estimativa do coeficiente de herdabilidade está relacionada com a seleção recorrente com progênies de meios-irmãos.

A estimativa do grau médio de dominância de 1,47, obtida neste trabalho, indica a presença de sobredominância ou pseudo-sobredominância. Cockerham \& Zeng (1996), Gardner (1963), Gardner et al. (1953), Gardner \& Lonnquist (1959), Moll et al. (1964), Robinson et al. (1949) e Wolf et al. (2000), apresentaram estimativas do grau médio de dominância (GMD) para produção de grãos superior a 1,00. Entretanto, é reconhecido que tais estimativas podem estar viesadas por causa do desequilíbrio de ligação.

Comstock \& Robinson (1952) demonstraram que quando dois locos gênicos estão ligados, uma covariância entre seus efeitos aditivos, que será positiva ou negativa dependendo da fase de ligação, e uma covariância entre seus efeitos de dominância (sempre positiva), estarão presentes. A fase de repulsão gênica proporciona $o$ aparecimento de valores superestimados do grau médio de dominância devido à superestimação da variância de dominância, enquanto que a fase de associação gênica proporciona a superestimação tanto da variância genética aditiva como da variância dominante. Então, na presença de desequilíbrio de ligação, as estimativas da variância genética aditiva e da variância dominante estarão viesadas.

Evidências experimentais confirmando o viés das estimativas de variância genética aditiva e da variância dominante também foram apresentadas por Gardner \& Lonnquist (1959), Moll et al. (1964), MorenoGonzález et al. (1975) e por Dudley (1994). Essas evidências foram obtidas pelas estimativas simultâneas em progênies $F_{2}$ de milho e em suas gerações avançadas, obtidas através de polinização ao acaso. Estes autores concluíram que várias gerações de recombinação quebraram fortes ligações gênicas, em 
fase de repulsão ou de associação, permitindo a aproximação ao equilíbrio de ligação e, consequentemente, demonstrando a superestimação ou subestimação dessas estimativas.

Gardner (1963) apresenta estimativas do $G \hat{M} D$ de produção de grãos em milho para populações $F_{2}, F_{4}, F_{8}, F_{13}$ e $F_{16}$, originadas de dois cruzamentos. Em um destes cruzamentos, o valor estimado do $G \hat{M} D$ foi de 1,68 em $\mathrm{F}_{2}, 1,24$ em $F_{8}$ e 1,09 em $F_{13}$; para 0 outro cruzamento, esses valores foram de 1,98 para $F_{2}, 1,04$ para $F_{4}, 0,72$ para $F_{8}$ e 0,62 para $F_{16}$. Pode-se notar uma redução progressiva e acentuada das estimativas do $G \hat{M} D$ com o avanço das gerações. Os resultados obtidos, embora tenham indicado dominância parcial ou completa para genes que controlam o caráter produção de grãos não excluem, porém, a possibilidade de existência de uma ação gênica sobredominante em um ou mais locos. O autor concluiu que a presença das ligações em fase de repulsão gênica provoca o aparecimento de estimativas de $G \hat{M} D$ na faixa da sobredominância, quando estas são obtidas para populações em gerações iniciais de recombinação. Entretanto, como salientado pelo autor, isto não exclui a possibilidade de sobredominância em alguns locos.

A população utilizada para avaliação de caracteres fenotípicos neste trabalho está em desequilíbrio de ligação, e assim, as estimativas da variância aditiva e/ou da variância dominante podem estar viesadas. Os dados apresentados para o caráter produção de grãos evidenciam que a estimativa da variância dominante não difere estatisticamente da estimativa da variância aditiva, uma vez que há sobreposição dos valores de seus intervalos de confiança. Este fato demonstra que a variância dominante pode estar superestimada e que a variância aditiva pode estar subestimada. Então, a fase de repulsão seria a conformação mais provável para grande parte dos locos envolvidos com a expressão deste caráter. Portanto, a estimativa do $G \hat{M} D$ obtida nesse trabalho indica a existência de pseudo-sobredominância para PG, apesar de não se poder descartar a possibilidade de alguns locos manifestarem sobredominância. 


\subsubsection{Prolificidade}

A estimativa da $\hat{\sigma}_{A}^{2}$ foi de $71,49 \times 10^{-4}$ (espigas planta-1 ${ }^{-1}$ sendo três vezes maior do que a estimativa da $\hat{\sigma}_{D}^{2}$, que foi de $23,28 \times 10^{-4}$ (espigas planta $\left.{ }^{-1}\right)^{2}$. Gardner et al. (1953), Gardner \& Lonnquist (1959), Moll et al. (1964), Robinson et al. (1949) e Wolf et al. (2000) também apresentaram estimativas de $\hat{\sigma}_{A}^{2}$ maiores do que estimativas de $\hat{\sigma}_{D}^{2}$. A estimativa da $\hat{\sigma}_{A E}^{2}$ foi de $19,97 \times 10^{-4}$ (espigas planta $\left.{ }^{-1}\right)^{2}$, sendo 2 vezes maior do que a estimativa da $\hat{\sigma}_{D E}^{2}$, que foi de $9,81 \times 10^{-4}$ (espigas planta $\left.{ }^{-1}\right)^{2}$, indicando que os efeitos aditivos apresentaram uma maior interação com ambientes do que os efeitos de dominância; as mesmas indicações foram obtidas por Moll et al. (1964) e Wolf et al. (2000). A estimativa do coeficiente de herdabilidade $\left(\hat{h}^{2}\right)$ foi de 0,66 (Tabela 7 ).

Para o grau médio de dominância foi obtida a estimativa de 0,81 , a qual indica a presença de dominância parcial. Esse resultado está próximo aos resultados obtidos por Gardner et al. (1953) e por Moll et al. (1964), os quais apresentaram $G \hat{M} D$ para prolificidade variando entre 0,72 e 0,77 . Entretanto, resultados reportados por Gardner \& Lonnquist (1959), Robinson et al. (1949) e Wolf et al. (2000) apresentam estimativas variando entre 0,32 a 0,50. Nota-se que a estimativa obtida por este trabalho é superior às estimativas apresentadas na literatura, indicando que o $G \hat{M} D$ pode estar superestimado. Esta supertimação pode estar sendo causada pela superestimação da variância dominante e pela subestimação da variância aditiva, tal como aconteceu para o caráter PG.

As estimativas da variância aditiva e do coeficiente de herdabilidade podem ser consideradas altas, evidenciando que as progênies possuem um bom nível de variabilidade genética e, também, que essa população pode apresentar elevada resposta à seleção para este caráter (Tabela 7).

\subsubsection{Altura da planta, da espiga e posição relativa da espiga}

Para o caráter AE, a estimativa da $\hat{\sigma}_{A}^{2}$ foi de $36,86\left(\mathrm{~cm} \text { planta }{ }^{-1}\right)^{2}$ sendo três vezes maior do que a estimativa da $\hat{\sigma}_{D}^{2}$, que foi de $10,17\left(\mathrm{~cm} \text { planta }{ }^{-1}\right)^{2}$. Dudley (1994), Gardner et al. (1953), Gardner \& Lonnquist (1959), Han \& 
Hallauer (1989), Moll et al. (1964), Robinson et al. (1949) e Wolf et al. (2000) também apresentaram resultados similares. Porém, a maior parte das estimativas obtidas por estes autores para a $\hat{\sigma}_{A}^{2}$ foram superiores, enquanto as estimativas de $\hat{\sigma}_{D}^{2}$ foram mais próximas aos valores obtidos por este trabalho. A estimativa da $\hat{\sigma}_{A E}^{2}$ de $13,63\left(\mathrm{~cm} \text { planta }{ }^{-1}\right)^{2}$ foi três vezes maior do que a estimativa da $\hat{\sigma}_{D E}^{2}$, que foi de $3,86\left(\mathrm{~cm} \text { planta }{ }^{-1}\right)^{2}$, indicando que os efeitos aditivos apresentaram maior interação com ambientes do que os efeitos de dominância. Han \& Hallauer (1989), Moll et al. (1964) e Wolf et al. (2000) também apresentaram resultados similares. A estimativa do coeficiente de herdabilidade $\left(\hat{h}^{2}\right)$ foi de 0,78 (Tabela 7 ).

Para o caráter AP, a estimativa da $\hat{\sigma}_{A}^{2}$ foi de $70,50\left(\mathrm{~cm} \text { planta }{ }^{-1}\right)^{2}$ sendo três vezes maior do que a estimativa da $\hat{\sigma}_{D}^{2}, 24,40\left(\mathrm{~cm} \text { planta }{ }^{-1}\right)^{2}$. Dudley (1994), Gardner \& Lonnquist (1959), Moll et al. (1964), Robinson et al. (1949) e Wolf et al. (2000) também apresentaram resultados similares. A estimativa da $\hat{\sigma}_{A E}^{2}, 22,54\left(\mathrm{~cm} \text { planta }{ }^{-1}\right)^{2}$ foi três vezes maior do que a estimativa da $\hat{\sigma}_{D E}^{2}$, que foi de $7,38\left(\mathrm{~cm} \mathrm{planta}^{-1}\right)^{2}$. Nota-se que os efeitos aditivos apresentaram maior interação com ambientes do que os efeitos de dominância. Moll et al. (1964) e Wolf et al. (2000) também apresentaram resultados similares. A estimativa do coeficiente de herdabilidade $\left(\hat{h}^{2}\right)$ foi de 0,81 (Tabela 7 ).

Para o caráter PRE, a estimativa da $\hat{\sigma}_{A}^{2}$ foi de $24,06\left(\mathrm{~cm} \text { planta }{ }^{-1}\right)^{2}$, sendo dez vezes maior do que a estimativa da $\hat{\sigma}_{D}^{2}$, que foi de 2,32 (cm planta $\left.{ }^{-1}\right)^{2}$. A estimativa da $\hat{\sigma}_{A E}^{2}$ foi de $9,05\left(\mathrm{~cm} \text { planta }{ }^{-1}\right)^{2}$, sendo três vezes maior do que a estimativa da $\hat{\sigma}_{D E}^{2}$, que foi de $2,75\left(\mathrm{~cm} \text { planta }{ }^{-1}\right)^{2}$. Este resultado indica que os efeitos aditivos apresentaram maior interação com ambientes do que os efeitos de dominância. A estimativa do coeficiente de herdabilidade $\left(\hat{h}^{2}\right)$ foi de 0,70 (Tabela 7 ).

Comparando-se as estimativas da $\hat{\sigma}_{A}^{2}$ com as estimativas da $\hat{\sigma}_{A E}^{2}$ obtidas para os três caracteres, nota-se que as estimativas da $\hat{\sigma}_{A}^{2}$ apresentaram valores maiores do que as correspondentes estimativas da $\hat{\sigma}_{A E}^{2}$. Comparando-se as estimativas da $\hat{\sigma}_{D}^{2}$ com as estimativas da $\hat{\sigma}_{D E}^{2}$, nota-se que, para os caracteres AE e AP, as estimativas da $\hat{\sigma}_{D}^{2}$ apresentaram valores maiores do que as correspondentes estimativas da $\hat{\sigma}_{D E}^{2}$. Entretanto, para o caráter PRE, a estimativa da $\hat{\sigma}_{D}^{2}$ apresentou valor menor do que a estimativa da $\hat{\sigma}_{D E}^{2}$ (Tabela 7). 
As estimativas dos graus médios de dominância foram de 0,74, 0,83 e 0,44 para os caracteres AE, AP e PRE, respectivamente, indicando dominância parcial. Essas estimativas obtidas são similares aos resultados apresentados para AE e AP por Dudley (1994) e por Gardner et al. (1953). Entretanto, as estimativas obtidas para AE e AP apresentadas por Gardner \& Lonnquist (1959), Moll et al. (1964), Robinson et al. (1949), e a estimativa obtida para AE por Han \& Hallauer (1989), foram inferiores, variando entre 0,00 a 0,66. Como comentado anteriormente, a maior parte das estimativas obtidas por estes autores para $\hat{\sigma}_{A}^{2}$ foram superiores às obtidas por este trabalho, sendo que as estimativas de $\hat{\sigma}_{D}^{2}$ foram próximas aos valores apresentados neste trabalho. Esta pode ter sido a causa da diferença entre as estimativas do $G \hat{M} D$ para $\mathrm{AE}$ e para AP.

Os coeficientes de herdabilidade $\mathrm{e}$ as estimativas da $\hat{\sigma}_{A}^{2}$ para os caracteres AE, AP e PRE apresentaram magnitude elevada. Esse resultado indica que a resposta à seleção pode ser elevada, uma vez que se trata de estimativas obtidas de uma população de meios-irmãos.

\subsubsection{Florescimento feminino, masculino e intervalo de florescimento}

Para o caráter FF, a estimativa da $\hat{\sigma}_{A}^{2}$ foi de $226,39 \times 10^{-2}$ (dias) $)^{2}$ sendo 5 vezes maior do que a estimativa da $\hat{\sigma}_{D}^{2}, 40,24 \times 10^{-2}$ (dias) ${ }^{2}$. Han \& Hallauer (1989) e Wolf et al. (2000) relataram resultados similares para estas estimativas. As estimativas da $\hat{\sigma}_{A E}^{2}$ e da $\hat{\sigma}_{D E}^{2}$ não foram obtidas devido à não significância das fontes de variação de interações progênies por ambiente e progênies por linhagem parental por ambientes. A estimativa do coeficiente de herdabilidade $\left(\hat{h}^{2}\right)$ foi de 0,83 (Tabela 7 ).

Para o caráter FM, a estimativa da $\hat{\sigma}_{A}^{2}$ foi de $167,82 \times 10^{-2}$ (dias) ${ }^{2}$ sendo 5 vezes maior do que a estimativa da $\hat{\sigma}_{D}^{2}, 30,80 \times 10^{-2}$ (dias) ${ }^{2}$. Gardner et al. (1953), Gardner \& Lonnquist (1959), Moll et al. (1964) e Wolf et al. (2000) apresentaram estimativas similares. A estimativa da $\hat{\sigma}_{A E}^{2}$ foi $21,78 \times 10^{-2}$ (dias) ${ }^{2}$. A estimativa da $\hat{\sigma}_{D E}^{2}$ não foi obtida devido à não significância da fonte de variação da interação de progênies com linhagem parental com ambientes. A estimativa do coeficiente de herdabilidade $\left(\hat{h}^{2}\right)$ foi de 0,82 (Tabela 7 ). 
Para o caráter IF, a estimativa da $\hat{\sigma}_{A}^{2}$ foi de $23,99 \times 10^{-2}$ (dias) ${ }^{2}$ sendo 6 vezes maior do que a estimativa da $\hat{\sigma}_{D}^{2}, 3,52 \times 10^{-2}(\text { dias })^{2}$. Resultados similares foram apresentados por Han \& Hallauer (1989) e por Wolf et al. (2000). As estimativas da $\hat{\sigma}_{A E}^{2}$ e da $\hat{\sigma}_{D E}^{2}$ não foram obtidas devido à não significância das fontes de variação de interações progênies por ambiente $(P x E)$ e progênies por linhagem parental por ambientes (PxTxE). A estimativa do coeficiente de herdabilidade $\left(\hat{h}^{2}\right)$ foi de 0,48 (Tabela 7 ).

As estimativas do grau médio de dominância foram de 0,60, 0,61 e 0,54 para os caracteres FF, FM e IF, respectivamente, indicando a existência de dominância parcial. A estimativa do GMD obtida para FF é similar às apresentadas por Han \& Hallauer (1989) e por Wolf et al. (2000). Para FM, a estimativa do grau médio de dominância é similar às apresentadas Gardner \& Lonnquist (1959) e Wolf et al. (2000) e menores do que as apresentadas por Gardner et al. (1953) e por Moll et al. (1964). Entretanto, todas as estimativas reportadas pelos autores acima citados variam de 0,35 a 0,90. A estimativa do grau médio de dominância obtida para o caráter IF é similar à apresentada por Wolf et al. (2000).

Os coeficientes de herdabilidade e as estimativas da $\hat{\sigma}_{A}^{2}$ para os caracteres FF, FM e IF apresentaram valores de elevada magnitude. Por se tratar de estimativas obtidas de uma população de meios-irmãos, a resposta à seleção pode ser elevada, principalmente para o caráter FF, o qual apresentou as maiores magnitudes de herdabilidade e de variância aditiva.

\subsubsection{Número de folhas}

A estimativa da $\hat{\sigma}_{A}^{2}$ foi de $94,41 \times 10^{-3}$ (folhas planta $\left.^{-1}\right)^{2}$ sendo 14 vezes maior do que a $\hat{\sigma}_{D}^{2}$, que foi de $6,74 \times 10^{-3}$ (folhas planta $\left.{ }^{-1}\right)^{2}$. A $\hat{\sigma}_{A E}^{2}$ foi $12,35 \times$ $10^{-3}$ (folhas planta $\left.{ }^{-1}\right)^{2}$. A $\hat{\sigma}_{D E}^{2}$ não foi obtida devido à não significância da fonte de variação da interação progênies por linhagem parental por ambientes. A estimativa do coeficiente de herdabilidade $\left(\hat{h}^{2}\right)$ foi de 0,84 . O grau médio de dominância de 0,38 indicou dominância parcial. Não foram encontrados estimativas para este caráter na literatura (Tabela 7). 
Este resultado demonstra a preponderância dos efeitos aditivos na manifestação deste caráter, indicando um grande potencial para seleção. A estimativa da herdabilidade também indica a possibilidade da obtenção de uma boa resposta à seleção para este caráter.

\subsubsection{Teor de umidade nos grãos}

A estimativa da $\hat{\sigma}_{A}^{2}$ foi de $18,73 \times 10^{-3}(\%)^{2}$ sendo 3 vezes maior do que a estimativa da $\hat{\sigma}_{D}^{2}$ que foi de $5,31 \times 10^{-3}(\%)^{2}$. As estimativas da $\hat{\sigma}_{A E}^{2}$ e da $\hat{\sigma}_{D E}^{2}$ não foram obtidas devido à não significância das fontes de variação de interações progênies por ambiente (PxE) e progênies por linhagem parental por ambientes (PxTxE). A estimativa do coeficiente de herdabilidade $\left(\hat{h}^{2}\right)$ foi de 0,30 . A estimativa do grau médio de dominância de 0,75 indicou dominância parcial. Não foram encontradas, na literatura utilizando o delineamento III, citações de estimativas de parâmetros genéticos para teor de umidade nos grãos (Tabela 7).

Apesar da estimativa da $\hat{\sigma}_{A}^{2}$ ter sido 3 vezes maior do que a estimativa da $\hat{\sigma}_{D}^{2}$, esta foi de pequena magnitude, indicando uma pequena variabilidade para este caráter. A estimativa do coeficiente de herdabilidade também foi de pequena magnitude, fazendo com a que a reposta à seleção seja pequena.

\subsubsection{Correlações entre caracteres}

Robinson et al. (1955) ressaltaram que a associação entre caracteres apresenta um grande valor prático, visto que a seleção em um caráter, inevitavelmente, poderá provocar modificações em diversos outros caracteres de valor econômico. Dentre as causas responsáveis pela correlação genética entre caracteres, tem-se o pleiotropismo e o desequilíbrio de ligação genético (Vencovsky, 1987). O primeiro caso ocorre quando um ou mais locos afetam alguns passos fisiológicos de diversos caracteres, enquanto que o segundo refere-se a blocos gênicos localizados em um mesmo cromossomo, com tendência a serem transmitidos em conjunto. A correlação entre caracteres 
pode ser explorada no melhoramento através da seleção indireta. Esta, segundo Vencovsky \& Barriga (1992), pode ser efetiva quando a herdabilidade do caráter secundário é maior do que a herdabilidade do caráter primário e a correlação entre caracteres for substancial.

Neste trabalho, foram obtidas estimativas de correlações genéticas aditivas $\left(\hat{r}_{A}\right)$ genéticas $\left(\hat{r}_{G}\right)$ e fenotípicas $\left(\hat{r}_{F}\right)$ para todas as 45 combinações possíveis entre os 10 caracteres analisados. Considerando todas estas combinações, as estimativas dos coeficientes de correlação aditiva $\left(\hat{r}_{A}\right)$ apresentaram intervalo de variação de $-0,64$ (PG e FF) a 0,94 (FF e FM). Os coeficientes de correlação genética $\left(\hat{r}_{G}\right)$ tiveram intervalo de -0,65 (PG e FF) a 0,94 (FF e FM). Os coeficientes de correlação fenotípica $\left(\hat{r}_{F}\right)$ tiveram intervalo de variação de -0,55 (PG e FF) a 0,90 (FF e FM). Observou-se, também, que todas as correlações aditivas apresentaram estimativas muito próximas das correlações genéticas, indicando que o efeito da correlação genética foi explicada, em sua grande parte, pela correlação aditiva. Constata-se ainda, que os valores obtidos de $\hat{r}_{A}, \hat{r}_{G}$ e $\hat{r}_{F}$, para cada combinação de caracteres, foram próximos em magnitude (Tabela 8).

De modo geral, foram obtidos valores positivos para as correlações entre o caráter PG e os caracteres PRO, AE, AP, PRE e IF; entre os caracteres PRO e IF; entre os caracteres relacionados ao porte da planta (AE, AP, PRE) entre si; e entre os caracteres FF e FM. Foram obtidas estimativas de correlações de baixa magnitude (tanto negativas quanto positivas), entre os caracteres $P G$ e $\mathrm{NF}$; entre os caracteres relacionados ao porte da planta (AE, AP, PRE) com os caracteres $F F$, FM e UM; entre os caracteres $A E$ e NF; entre os caracteres PRE e IF; e entre os caracteres relacionados ao florescimento (FF, FM, IF) com os caracteres NF e UM. Foram obtidas estimativas de correlações negativas para as combinações entre o caráter $P G$ e os caracteres FF e FM; entre o caráter PRO e os caracteres FF e FM; entre os caracteres PRE e NF; e entre os caracteres IF e FF (Tabela 8).

A estimativa do coeficiente de correlação genética aditiva entre os caracteres PG e PRO foi positiva e alta $(0,51)$, como esperado, pois a prolificidade é um dos componentes da produção de grãos. Estes valores são similares aos resultados apresentados por outros autores (Lonnquist, 1967; Pizaia, 2000; Souza Jr. et al., 1985). As estimativas obtidas indicam que os 
locos que estão envolvidos no controle destes caracteres podem estar ligados ou ter ação pleiotrópica, e que a seleção para o aumento da prolificidade atua no sentido de aumentar a produção de grãos.

As estimativas das correlações genéticas aditivas entre o caráter $P G$ e os caracteres relacionados ao porte da planta ( $A E, A P$ e PRE), apresentaram valores de 0,52, 0,47 e 0,33, respectivamente. Sabe-se que o valor ideal para a estimativa de PRE é 0,50 , isto é, que a espiga esteja localizada na parte mediana da planta. Um aumento significativo no valor de PRE pode comprometer a resistência das plantas ao acamamento e/ou ao quebramento. Como a média do caráter PRE foi de 0,54 , um aumento nesse valor seria indesejável. Portanto, a correlação positiva entre PG e PRE pode se constituir em um problema para o melhoramento do caráter produção de grãos (PG). As correlações positivas entre $P G$ e AE e entre $P G$ e AP podem dificultar a seleção para produção de grãos, uma vez que aumentando-se a produção de grãos, os valores dos caracteres AP e AE também serão aumentados, causando maior probabilidade de ocorrência de acamamento e quebramento das plantas.

Entre os caracteres $P G$ e FF e entre $P G$ e $F M$ as estimativas das correlações genéticas aditivas foram negativas, com valores -0,64 e -0,60, respectivamente. Assim, a seleção para produção de grãos poderá acarretar a redução do ciclo, o que seria altamente desejável. Deve-se salientar, entretanto, que os resultados deste trabalho são específicos para a população de plantas estudada, cujo intervalo de variação detectado para os caracteres FF e FM foi muito grande. Foram obtidas progênies protândricas e protogênicas, sendo que grande parte apresentou 0 florescimento feminino e masculino quase coincidentes. Como as estimativas da herdabilidade para os caracteres FF e FM foram maiores do que as estimativas obtidas para PG, a seleção conjunta entre produção de grãos e redução do ciclo das plantas pode ser mais efetiva do que a seleção apenas para o caráter $P G$, quando o objetivo for 0 melhoramento do caráter PG.

Entretanto, a estimativa da correlação aditiva para PG e IF foi positiva, 0,36 , indicando que quanto maior o intervalo de florescimento, maior será a produção de grãos. Como a média do caráter IF foi negativa (-0,72 dias), podese deduzir que essa população terá produção de grãos aumentada com o aumento da média do caráter IF. Outros trabalhos publicados apresentaram 
correlação negativa entre os caracteres PG e IF mas, nestes casos, a média do caráter IF foi positiva (Agrama \& Moussa, 1996; Guei \& Wassom, 1992; Ribaut et al., 1997).

Resultados apresentados por diversos autores demonstram que um menor intervalo de florescimento proporciona uma maior resistência ao estresse hídrico, acarretando uma maior produção de grãos (Bolaños \& Edmeads, 1996, 1993; Herrero \& Johnson, 1981; Struick et al., 1989). Como os experimentos do presente trabalho foram conduzidos em ambientes que sofreram um mínimo de estresse hídrico, os resultados obtidos não podem ser utilizados para qualquer inferência a esse respeito.

Para os caracteres PG e UM foi obtida uma estimativa positiva do coeficiente de correlação aditiva, porém, de pequena magnitude, 0,26. Esta estimativa baixa indica uma pequena associação entre esses caracteres.

As correlações aditivas entre o caráter $\mathrm{PRO}$ e os caracteres relacionados ao porte da planta (AE, AP e PRE) foram positivas e baixas, sendo 0,30, 0,24 e 0,23 , respectivamente. Os resultados obtidos indicam uma pequena associação entre esses caracteres. Entre o caráter PRO e os caracteres FF e FM, as estimativas foram negativas, com valores $-0,47$ e $-0,38$. Entretanto, a estimativa da correlação genética aditiva entre os caracteres PRO e IF foi positiva, 0,23. A correlação entre os caracteres PRO e UM foi positiva, porém, de pequena magnitude $(0,33)$.

Entre os caracteres AE e AP a estimativa do coeficiente de correlação genética aditiva foi alta, 0,88, como esperado. Essa estimativa, obtida entre os caracteres AE e PRE $(0,71)$ e entre os caracteres AP e PRE $(0,24)$ indica que 0 caráter PRE está mais correlacionado com o caráter $\mathrm{AE}$ do que com o caráter AP. As estimativas das correlações genéticas aditivas obtidas entre os caracteres relacionados ao porte da planta ( $A E, A P$ e PRE) e os caracteres relacionados ao florescimento (FF, FM e IF), foram de pequena magnitude. Entre os caracteres relacionados ao porte da planta e o caráter UM, também foram obtidos valores de baixa magnitude para as correlações genéticas aditivas.

A estimativa do coeficiente de correlação genética aditiva entre FF e FM foi de 0,94. A estimativa desse coeficiente entre FF e IF e entre FM e IF foram de $-0,53$ e de $-0,22$, respectivamente. Entre os caracteres relacionados ao 
florescimento (FF, FM e IF) e o caráter UM, as estimativas das correlações genéticas aditivas também foram de pequena magnitude, sendo $0,15,0,10$, 0,18 , respectivamente.

Entre os caracteres PG e NF a correlação aditiva foi muito baixa $(-0,05)$, enquanto que entre os caracteres PRO e NF a correlação aditiva foi negativa mas de baixa magnitude, $-0,27$, indicando que quanto maior for a produção de grãos e o número de espigas, menor será o número de folhas. Hoyt \& Bradfield (1962) e Allison \& Watson (1966) relataram que cerca de 50\% dos carboidratos acumulados nos grãos de milho são produzidos pelas folhas localizadas no terço superior da planta, aproximadamente $30 \%$ são provenientes das folhas do terço médio, e o restante provém das folhas distribuídas na parte basal do colmo. Assim, esperava-se que a contribuição dos fotossintetizados das folhas acima da espiga superior, pudessem ter uma elevada contribuição para a produção de grãos. Entretanto, como a correlação entre estes caracteres foi muito baixa, outros fatores como a eficiência fotossintética, por exemplo, pode ter contribuído para a baixa correlação encontrada.

As estimativas entre os caracteres relacionados ao florescimento (FF, FM e IF) e o caráter NF foram baixas sendo $0,15,0,10$ e -0,18, respectivamente.

A estimativas da correlação genética aditiva entre os caracteres $A P, A E ~ e$ PRE e o caráter NF foram diferentes entre si. Entre os caracteres AP e NF, essa estimativa foi positiva, mas de baixa magnitude $(0,16)$. Para AE e NF, essa estimativa foi negativa e de baixa magnitude, $(-0,16)$. Para PRE e NF essa estimativa foi negativa $(-0,52)$. Esses resultados indicam que: 1) quanto maior a altura da planta, maior será o número de folhas, 2) quanto menor for a altura da espiga, maior será o número de folhas, 3) quanto menor for a posição relativa da espiga, maior será o número de folhas. Pode-se notar que esses resultados são concordantes entre si, e podem ser traduzidos da seguinte forma: quanto maior a porção superior da planta (acima da primeira espiga), maior será o número de folhas. 


\subsection{Análises dos marcadores utilizando o delineamento III}

Foram efetuadas análises dos 140 marcadores microssatélites utilizando a metodologia de Cockerham \& Zeng (1996) para os dez caracteres avaliados. Os testes de significância para os efeitos dos contrastes de cada marcador e para os efeitos das interações dos contrastes por ambientes, foram realizados de acordo com a análise de variância apresentada na Tabela 4, página 60. Nestas análises, a significância para o contraste $1\left(\mathrm{C}_{1}\right)$ indica que o coeficiente de regressão parcial $\beta_{1}$ difere de zero e, portanto, detecta efeitos aditivos de QTLs associados ao marcador; da mesma forma, o contraste $3\left(C_{3}\right)$ está relacionado a $\beta_{3}$ e detecta efeitos de dominância quando significativo; enquanto que o contraste $2\left(C_{2}\right)$ e o contraste $4\left(C_{4}\right)$, que estão relacionados a $\beta_{2}$ e $\beta_{4}$, respectivamente, detectam efeitos epistáticos do tipo aditivo $x$ aditivo (axa) e dominante $\mathrm{x}$ dominantes $(d x d)$, e aditivo $\mathrm{x}$ dominante $(a x d)$ e dominante $\mathrm{x}$ aditivo ( $d x a)$, respectivamente. Note que se $\beta_{2}$ e/ou $\beta_{4}$ forem significativos, indica que mais que um QTL está ligado ao marcador e que estes QTLs apresentam interação interalélica (epistasia). As significâncias dos efeitos das interações dos contrastes com ambientes $\mathrm{C}_{1}+\mathrm{E}, \mathrm{C}_{2}+\mathrm{E}, \mathrm{C}_{3}+\mathrm{E}$ e $\mathrm{C}_{4}+\mathrm{E}$, para os coeficientes de regressão $\beta_{1}, \beta_{2}, \beta_{3}$ e $\beta_{4}$, respectivamente, indicam que ocorreram interações dos efeitos aditivos com ambientes $\left(\sigma_{\beta I E}^{2}\right)$, efeitos epistáticos axa e $d x d$ com ambientes $\left(\sigma_{\beta 2 E}^{2}\right)$, efeitos dominantes com ambientes $\left(\sigma_{\beta 3 E}^{2}\right)$ e efeitos epistáticos axd e $d x a$ com ambientes $\left(\sigma_{\beta 4 E}^{2}\right)$. Em outras palavras, detectam interação QTLs por ambientes (Tabelas 15 a 19).

Foi detectada significância $(p \leq 0,05)$ para pelo menos um dos efeitos $\left(\beta_{1}\right.$, $\beta_{2}, \beta_{3}, \beta_{4}, \sigma_{\beta 1 E}^{2}, \sigma_{\beta 2 E}^{2}, \sigma_{\beta 3 E}^{2}$ e/ou $\sigma_{\beta 4 E}^{2}$ ) em todos os cromossomos para todos os caracteres. O caráter AP apresentou o maior número (130) de marcadores com significância para pelo menos um desses efeitos, e o caráter IF apresentou o menor número (69). O caráter FF apresentou maior número de marcadores com significância para o coeficiente $\beta_{1}$ (78), o caráter NF apresentou maior número de marcadores com significância para $\beta_{2}$ (61), o caráter PG apresentou maior número de marcadores com significância para $\beta_{3}$ (99), enquanto o caráter AP apresentou maior número de marcadores com significância para $\beta_{4}$ (38). Para todos os caracteres foi detectado maior número 
de marcadores com significância para $\beta_{1}$ e/ou para $\beta_{3}$, ou seja, para os efeitos aditivos e/ou dominantes, respectivamente. Para o caráter UM foi detectado maior número (36) de marcadores com significância para interações de contrastes por ambientes $\left(\sigma_{\beta 1 E}^{2}, \sigma_{\beta 2 E}^{2}, \sigma_{\beta 3 E}^{2}\right.$ e/ou $\left.\sigma_{\beta 4 E}^{2}\right)$, enquanto que para o caráter NF nenhum marcador apresentou significância para esses efeitos de interações.

Neste trabalho ficou pré-estabelecido que, para todos os marcadores, os alelos oriundos da linhagem L-14-04 seriam considerados favoráveis para o efeito aditivo e exerceriam dominância sobre os alelos da linhagem L-08-05. Isso deve ser feito para a interpretação correta dos resultados desta análise. Em outras palavras, se o valores dos coeficientes $\beta_{1}$ (aditivo) e $\beta_{3}$ (dominante) forem positivos, indicarão que os alelos com efeitos aditivos favoráveis são oriundos da linhagem L-14-04 e que estes são dominantes sobre os alelos da linhagem L-08-05. Entretanto, se o valor obtido para o coeficiente $\beta_{1}$ for negativo, indicará que o alelo com efeito aditivo favorável será oriundo da linhagem L08-05. Da mesma forma, se o valor obtido para o coeficiente $\beta_{3}$ for negativo, indicará que o alelo da linhagem L-08-05 exerce dominância sobre 0 alelo da linhagem L-14-04. Assim, se existirem alelos favoráveis em ambas as linhagens parentais, poderá ocorrer, para os efeitos aditivos (a), um cancelamento na soma final de todos os locos. Por outro lado, como o milho deve possuir dominância unidirecional, pois apresenta uma considerável depressão por endogamia, os efeitos dominantes (d) serão positivos na maior parte dos locos, reduzindo a possibilidade de cancelamento.

\subsubsection{Produção de grãos}

Para o caráter PG foram detectados 127 marcadores $(90,71 \%)$ que apresentaram pelo menos um dos coeficientes ou efeitos $\left(\beta_{1}, \beta_{2}, \beta_{3}, \beta_{4}, \sigma_{\beta I E}^{2}\right.$, $\sigma_{\beta 2 E}^{2}, \sigma_{\beta 3 E}^{2}$ e/ou $\left.\sigma_{\beta 4 E}^{2}\right)$ significativo. Foram detectados $60(42,86 \%), 16$ (11,43\%), 99 (70,71\%), e 35 (25,00\%) marcadores com significância para $\beta_{1}, \beta_{2}$, $\beta_{3}$ e $\beta_{4}$, respectivamente (Tabelas 9 e 15). 
Pode-se notar que o número de marcadores com significância para o coeficiente $\beta_{1}$ é elevado, sendo menor apenas do que o número detectado para o coeficiente $\beta_{3}$. Este resultado indica que os efeitos aditivos podem exercer uma considerável influência na manifestação do caráter PG. Os marcadores que apresentaram significância para $\beta_{1}$ estão localizados principalmente nos cromossomos 1, 9 e 10, sendo que o cromossomo 4 não apresentou marcadores com significância para esse coeficiente (Tabelas 9 e 15).

A grande proporção de marcadores com significância para $\beta_{3}$ indica que, para a manifestação deste caráter, os efeitos dominantes possuem função relevante. Os cromossomos 1, 2, 6, 8 e 10 apresentaram quase todos seus marcadores com significância para $\beta_{3}$. Isso indica que quase todas as regiões desses cromossomos estão envolvidas na expressão fenotípica desse caráter (Tabelas 9 e 15).

Para $\beta_{2}$ foram detectados 16 marcadores (11,43\%) com significância, localizados principalmente nos cromossomos 1,4 e 7 . Para $\beta_{4}$ foram detectados 35 marcadores $(25,00 \%)$ com significância, localizados principalmente nos cromossomos 1, 4, 5 e 9. Como não é possível distinguir os diferentes tipos de efeitos epistáticos ( $a x a, d x d$, axd e $d x a$ ), empregando a metodologia adotada neste trabalho, esses serão considerados conjuntamente. Seis marcadores apresentaram simultaneamente significância para os efeitos $\beta_{2}$ e $\beta_{4}$. Assim, somando-se o número dos marcadores significativos para $\beta_{2}$ (16) com os significativos para $\beta_{4}$ (35) e subtraindo-se os marcadores com significância simultânea para estes dois coeficientes (6), constata-se que foram detectados 45 marcadores $(32,14 \%)$ que apresentaram significância para efeitos epistáticos, indicando que a epistasia é importante para o caráter PG.

Os valores de $\beta_{1}$ variaram de $-5,17 \mathrm{~g}$ planta $^{-1}$ a $2,45 \mathrm{~g} \mathrm{planta}^{-1}$, sendo obtidos valores negativos para 48 marcadores e valores positivos para 12 marcadores; para $\beta_{2}$ a variação foi de $-0,72$ g planta $^{-1}$ a 0,79 g planta $^{-1}$, sendo 10 negativos e 6 positivos; para $\beta_{3}$ a variação foi de $-0,72 \mathrm{~g} \mathrm{planta}^{-1}$ a $5,73 \mathrm{~g}$ planta $^{-1}$, sendo 1 negativo e 98 positivos; para $\beta_{4}$ a variação foi de $-1,19 \mathrm{~g}$ planta $^{-1}$ a $0,84 \mathrm{~g} \mathrm{planta}^{-1}$, sendo 9 positivos e 26 negativos. Esse resultado indica que a maior parte dos efeitos aditivos favoráveis é devido aos alelos da linhagem L-08-05, enquanto que a maior parte dos efeitos dominantes é devido 
à ação dominante dos alelos da linhagem L-14-04 sobre os alelos da linhagem L-08-05.

Pode-se constatar que os valores, em módulo, dos efeitos dominantes (d) foram maiores do que os aditivos (a), os quais foram maiores do que os epistáticos (e). Considerando os coeficientes simultaneamente significativos para cada marcador, verifica-se que os efeitos aditivos e dominantes são, em módulo, de 1 a 10 vezes e de 1 a 12 vezes, respectivamente, maiores do que os efeitos epistáticos. Isto demonstra que alguns locos envolvidos com a expressão deste caráter sofrem uma forte influência dos efeitos epistáticos, visto que, como comentado anteriormente, essa análise detecta apenas uma pequena parte desses efeitos (Tabela 15).

Surpreendentemente, porém, foram detectados apenas 10 dos 140 marcadores $(7,14 \%)$ que apresentaram efeitos de interação contraste por ambiente $\left(\sigma_{\beta 1 E}^{2}, \sigma_{\beta 2 E}^{2}\right.$ e/ou $\left.\sigma_{\beta 3 E}^{2}\right)$ significativos $(\mathrm{P} \leq 0,05)$. Nove marcadores apresentaram $\sigma_{\beta I E}^{2}$ significativo, um marcador apresentou significância para $\sigma_{\beta 2 E}^{2}$ e um marcador apresentou significância para $\sigma_{\beta 3 E}^{2}$; não foi detectado marcador com significância para $\sigma_{\beta 4 E}^{2}$; um marcador apresentou significância para $\sigma_{\beta 1 E}^{2}$ e $\sigma_{\beta 2 E}^{2}$ simultaneamente. Esses marcadores estão localizados nos cromossomos 3, 4, 5, 7 e 8 . Nos cromossomos 5 e 8 foram detectados 4 e 3 marcadores significativos, respectivamente; apenas um marcador apresentou significância em cada um dos cromossomos 3, 4 e 7 (Tabela 15).

Em resumo, pode-se notar que, apesar da existência de alguns intervalos mapeados mais ou menos extensos sem a presença de marcadores, os resultados das análises usando o delineamento III forneceram importantes subsídios para melhor interpretação da variação fenotípica desse caráter, nessa população. Marcadores com coeficientes $\beta_{3}$ significativos foram detectados para todos os cromossomos, sendo que a maior parte dos alelos oriundos da linhagem L-14-04 exercem dominância sobre os alelos da L-08-05. Coeficientes $\beta_{1}$ significativos também foram detectados em marcadores de quase todos os cromossomos, sendo os alelos favoráveis oriundos, em sua maior parte, da linhagem L-08-05. Coeficientes $\beta_{2}$ e/ou $\beta_{4}$ (efeitos epistáticos) foram importantes para a manifestação de $\mathrm{PG}$, sendo detectados maior número de marcadores com significância nos cromossomos 1, 4, 5, 7 e 9. 
Cockerham \& Zeng (1996), utilizando 73 marcadores, relataram que 23,30\%, 16,44\%, 93,15\% e 34,25\% destes apresentaram significâncias para $\beta_{1}$, $\beta_{2}, \beta_{3}$ e $\beta_{4}$, respectivamente. Nota-se que a porcentagem dos marcadores com significâncias para $\beta_{1}$ é menor, enquanto as porcentagens dos outros três coeficientes, $\beta_{2}, \beta_{3}$ e $\beta_{4}$, são maiores do que as porcentagens encontradas neste trabalho. Isto pode ser devido ao maior valor do grau médio de dominância encontrado por estes autores $(1,96)$, ao menor número de marcadores utilizados naquele trabalho (73) e, também, à diferença entre os materiais genéticos, de origem temperada e de origem tropical.

Para o coeficiente $\beta_{1}$ Cockerham \& Zeng (1996) obtiveram valores variando de $-1,39$ a 2,43 (bushels acre ${ }^{-1}$ ) enquanto que para o coeficiente $\beta_{3}$ os valores variaram de $-0,97$ a 5,06 (bushels acre ${ }^{-1}$ ). Para os valores dos efeitos $\beta_{1}$ foram detectados 3 marcadores com sinais negativos e $14 \mathrm{com}$ sinais positivos; dentre esses, 13 positivos estão localizados nos cromossomos 3 e 4 . Para os valores de $\beta_{3}$, foram detectados apenas três marcadores com valores negativos, nos cromossomos 3 e 9 , e 65 com valores positivos. A magnitude dos valores dos coeficientes $\beta_{3}$ foi maior do que para $\beta_{1}$.

Cockerham \& Zeng (1996) encontraram 9 marcadores (12,33\%) com significância para $\sigma_{\beta I E}^{2}$ e $\sigma_{\beta 3 E}^{2}$, sendo 2 marcadores nos cromossomos 1 e 10, e um marcador em cada um dos cromossomos 2, 4, 6, 7 e 9. Os autores salientaram que era esperado um número maior de marcadores com significância para interação com ambientes.

Comparando-se os resultados obtidos por este trabalho com os obtidos por Cockerham \& Zeng (1996), constata-se diferenças para os sinais dos valores do coeficiente $\beta_{1}$. Para o cromossomo 3 , os sinais de todos os valores de $\beta_{1}$ foram positivos para 0 trabalho destes autores e negativos para 0 presente trabalho. Para os valores de $\beta_{3}$, entretanto, foi constatada uma grande similaridade para todos os cromossomos entre os dois trabalhos. Saliente-se que foram designadas como linhagens mais produtivas per se, sendo seus alelos denominados como favoráveis, as linhagens B73 e L-14-04, utilizadas no trabalho destes autores e neste trabalho, respectivamente. Então, a similaridade constatada para $\beta_{3}$ constitui uma importante indicação de que, para um híbrido entre duas linhagens endogâmicas de milho, a linhagem parental 
mais produtiva contribui com os alelos que exercem dominância sobre os alelos da outra linhagem parental menos produtiva.

Como salientaram Cockerham \& Zeng (1996), os efeitos epistáticos detectados de QTLs ligados aos marcadores referem-se a uma pequena porção dos efeitos presentes. Isso ocorre porque os coeficientes de regressão parciais $\beta_{2}$ e $\beta_{4}$ são funções dos respectivos contrastes divididos por 12 , isto é: $\beta_{2}=$ $\mathrm{C}_{2} / 12$ e $\beta_{4}=\mathrm{C}_{4} / 12$. Assim, os efeitos epistáticos significativos podem, potencialmente, serem muito mais elevados do que o detectado por esta análise. Portanto, os autores enfatizam que, para os resultados apresentados, os efeitos epistáticos podem ter a mesma importância que os efeitos de dominância e/ou aditivos na expressão do caráter produção de grãos.

Considerando que os resultados para a interação contrastes por ambientes apresentados por Cockerham \& Zeng (1996) foram obtidos para uma população de clima temperado, era esperado maior porcentagem de marcadores com significância para interação com ambientes no presente trabalho. No entanto, essa expectativa não se confirmou e ainda, foi detectada menor porcentagem de marcadores com esses efeitos significativos. Entretanto, deve-se levar em consideração que os experimentos destes autores foram avaliados em três estados diferentes, em seis ambientes e com apenas uma repetição por ambiente, enquanto que, para este trabalho, os experimentos foram avaliados em diferentes épocas de plantio, em diferentes locais, com duas repetições por local, mas apenas no município de Piracicaba, SP. Além do mais, a maior parte dos experimentos foi conduzida sob irrigação. Dessa forma, a precisão experimental para o caráter $P G$ neste trabalho, apesar do clima tropical, pode ter sido menor do que aquela relatada pelos autores acima citados.

QTLs para produção de grãos em milho foram detectados por outros autores, tais como por Stuber et al. (1992) para todos os cromossomos, exceto para o de número 6; por Ajmone-Marsan et al. (2001) e por Berke \& Rocheford (1995) para os cromossomos 2, 3, 4 e 5; por Veldboom \& Lee (1996) para os cromossomos 3, 4 e 5; e por Edwards et al. (1992) para os cromossomos 3, 4 e 9. Os resultados apresentados neste trabalho demonstram a detecção de QTLs em todos os cromossomos. Entretanto, devido à diferença entre os métodos de análise de QTLs empregados, torna-se difícil qualquer tipo de comparação. 
Além do mais, todos esses autores trabalharam com populações de clima temperado, enquanto que os resultados obtidos por este trabalho representam material de clima tropical.

\subsubsection{Prolificidade}

Para o caráter prolificidade 109 locos (77,86\%) apresentaram significância para pelo menos um dos coeficientes ou efeitos $\left(\beta_{1}, \beta_{2}, \beta_{3}, \beta_{4}\right.$, $\sigma_{\beta 1 E}^{2}, \sigma_{\beta 2 E}^{2}, \sigma_{\beta 3 E}^{2}$ e/ou $\sigma_{\beta 4 E}^{2}$ ). Foram detectados 47 (33,57\%), $27(19,29 \%)$, $61(43,57 \%)$, e $23(16,43 \%)$ marcadores com significância $(P \leq 0,05)$ para $\beta_{1}, \beta_{2}$, $\beta_{3}$ e $\beta_{4}$, respectivamente (Tabelas 10 e 15).

Para o coeficiente $\beta_{1}$ foi constatado um número expressivo de marcadores com significância, indicando sua importância na manifestação do caráter PRO. Esses marcadores estão localizados principalmente nos cromossomos 2, 3, 5 e 7. O cromossomo 8 não apresentou significância para nenhum dos seus marcadores (Tabelas 10 e 15).

Foi detectado maior porcentagem de marcadores com significância para $\beta_{3}$ do que para os demais coeficientes, indicando a maior importância dos efeitos dominantes com relação aos efeitos aditivos e epistáticos. Os cromossomos 1, 2, 5 e 10 apresentaram o maior número de marcadores com significância para $\beta_{3}$. Isso indica que quase todas as regiões desses cromossomos estão envolvidas na expressão fenotípica desse caráter. Entretanto, o cromossomo 3 não apresentou significância para nenhum dos seus marcadores e o cromossomo 7 apresentou apenas um marcador com significância para este coeficiente (Tabelas 10 e 15).

Para os coeficientes $\beta_{2}$ foram detectados 27 (19,29\%) marcadores com significância, sendo 9 localizados no cromossomo 4. Para $\beta_{4}$ foram detectados 23 marcadores com significância (16,43\%), sendo 5 localizados no cromossomo 3. Dois marcadores apresentaram simultaneamente significância para os efeitos $\beta_{2}$ e $\beta_{4}$. Assim, 48 marcadores (34,29\%) apresentaram significância para efeitos epistáticos, indicando que a epistasia é importante para o caráter PRO. Pode-se notar que o número de marcadores que apresentaram significância para os efeitos epistáticos (48) é praticamente igual ao número obtido para $\beta_{1}$ (47), 
indicando que os efeitos epistáticos são tão importantes quanto os efeitos aditivos para a manifestação desse caráter.

Em resumo, os efeitos dominantes foram detectados para marcadores de todos os cromossomos, exceto para o de número 3, sendo a maior parte dos alelos favoráveis oriundos da linhagem L-14-04. Os efeitos aditivos também foram detectados para todos os cromossomos, exceto para o de número 8 , sendo os alelos positivos oriundos, em sua maior parte, da linhagem L-08-05. Os efeitos epistáticos significativos também foram detectados, notadamente em marcadores dos cromossomos 4, 6 e 10.

Os valores dos coeficientes de regressão variaram de $-2,60 \times 10^{-2}$ espigas planta $^{-1}$ a $1,64 \times 10^{-2}$ espigas planta $^{-1}$ para $\beta_{1}$, sendo que 7 apresentaram valores positivos, localizados nos cromossomos 4 e 5 , e os outros 40 apresentaram valores negativos; para $\beta_{2}$ os valores variaram de $-0,62$ $\times 10^{-2}$ espigas planta ${ }^{-1}$ a $0,68 \times 10^{-2}$ espigas planta ${ }^{-1}$, sendo 13 negativos e 14 positivos; para $\beta_{3}$ os valores variaram de $-0,49 \times 10^{-2}$ espigas planta ${ }^{-1}$ a 2,17 $x$ $10^{-2}$ espigas planta ${ }^{-1}$, sendo que todos eles apresentaram valores positivos; para $\beta_{4}$ os valores variaram de $-0,51 \times 10^{-2}$ espigas planta ${ }^{-1}$ a $0,56 \times 10^{-2}$ espigas planta ${ }^{-1}$, sendo 11 negativos e 14 positivos. Esse resultado indica que a maior parte dos efeitos aditivos favoráveis é devido aos alelos da linhagem L08-05, enquanto que a maior parte dos efeitos dominantes é devida à ação dos alelos da linhagem L-14-04 (Tabela 15).

Pode-se constatar que os valores, em módulo, dos efeitos aditivos e dominantes são maiores do que os efeitos epistáticos, ou seja, a>d>e. Considerando, para cada marcador, os efeitos simultaneamente significativos, os efeitos aditivos são, em módulo, de 1 a 8 vezes maiores do que os efeitos epistáticos, enquanto que os efeitos dominantes são de 2 a 4 vezes maiores. Então, pode-se deduzir que os efeitos epistáticos podem ser tão importantes quanto os efeitos dominantes ou aditivos para a manifestação desse caráter (Tabelas 10 e 15).

Vinte marcadores (14,29\%) apresentaram significância para a interação contraste por ambiente: 16 para $\sigma_{\beta 1 E}^{2}(11,43 \%), 8$ para $\sigma_{\beta 2 E}^{2}(5,71 \%) 1$ para $\sigma_{\beta 3 E}^{2}(0,71 \%)$ e 1 para $\sigma_{\beta 4 E}^{2}(0,71 \%) ; 5$ marcadores apresentaram significância simultânea para $\sigma_{\beta I E}^{2}$ e para $\sigma_{\beta 2 E}^{2}$; e 1 marcador apresentou 
significância simultânea para $\sigma_{\beta 2 E}^{2}$ e para $\sigma_{\beta 3 E}^{2}$. No cromossomo 4 foram detectados 7 marcadores com significância para $\sigma_{\beta 1 E}^{2}$, sendo que 4 destes são simultaneamente significativos para $\sigma_{\beta 2 E}^{2}$.

Cockerham \& Zeng (1996), relataram que 13,70\%, 12,33\%, 13,70\% e $4,11 \%$ dos marcadores apresentaram significâncias para $\beta_{1}, \beta_{2}, \beta_{3}$ e $\beta_{4}$, respectivamente. Para as interações contrastes por ambiente, estes autores relataram que $17,81 \%, 1,37 \%, 9,59 \%$ e $8,22 \%$ dos marcadores apresentaram significâncias para $\sigma_{\beta 1 E}^{2}, \sigma_{\beta 2 E}^{2}, \sigma_{\beta 3 E}^{2}$ e $\sigma_{\beta 4 E}^{2}$, respectivamente.

Nota-se que os resultados entre os dois trabalhos são muito diferentes. Entretanto, Stuber et al. (1992), que cederam as avaliações fenotípicas para Cockerham \& Zeng (1996), salientam que a ausência de QTLs detectados para este caráter é devido à falta de variabilidade entre as linhagens parentais usadas para a obtenção das progênies retrocruzadas. Dessa forma, fica evidente que as linhagens parentais usadas neste trabalho possuem maior variabilidade genética do que as utilizadas por estes autores. Entretanto, devese considerar que as condições experimentais e a variabilidade genética existente para este caráter nas duas populações estudadas foram tão discrepantes que poderá ter inviabilizado qualquer tipo de comparação.

\subsubsection{Altura da planta, da espiga e posição relativa da espiga}

Para os caracteres AE, AP e PRE, foram detectados 113 (80,71\%), 130 $(92,86 \%)$ e $76(54,29 \%)$ marcadores que apresentaram pelo menos um dos coeficientes ou efeitos $\left(\beta_{1}, \beta_{2}, \beta_{3}, \beta_{4}, \sigma_{\beta 1 E}^{2}, \sigma_{\beta 2 E}^{2}, \sigma_{\beta 3 E}^{2}\right.$ e/ou $\left.\sigma_{\beta 4 E}^{2}\right)$ significativo. Para o caráter AE foram detectados 45 (32,14\%), 28 (20,00\%), 74 $(52,86 \%)$, e $28(20,00 \%)$ marcadores com significância para $\beta_{1}, \beta_{2}, \beta_{3}$ e $\beta_{4}$, respectivamente. Para o caráter AP foram detectados $58(41,43 \%), 37$ (26,43\%), 89 (63,57\%), e 38 (27,14\%) marcadores com significância para $\beta_{1}, \beta_{2}$, $\beta_{3}$ e $\beta_{4}$, respectivamente. Para o caráter PRE foram detectados 41 (29,29\%), 24 $(17,14 \%), 8(5,71 \%)$, e $3(2,14 \%)$ marcadores com significância para $\beta_{1}, \beta_{2}, \beta_{3}$ e $\beta_{4}$, respectivamente (Tabelas 11, 16 e 17). 
Para o coeficiente $\beta_{1}$ foi constatado um número expressivo de marcadores com significância para os três caracteres. Para AE e AP, esses marcadores estão localizados principalmente nos cromossomos 3, 6, 7 e 9, enquanto que para PRE, eles estão mais presentes nos cromossomos 1, 4, 5 e 10. Para os caracteres $A E$ e AP os efeitos aditivos foram de menor importância do que os efeitos dominantes e epistáticos, enquanto que para o caráter PRE os efeitos aditivos foram preponderantemente mais importantes do que os demais efeitos (Tabelas 11, 16 e 17).

Para o coeficiente $\beta_{3}$ a maior parte dos marcadores apresentaram significância para os caracteres $A E$ e AP, estando presentes em todos os cromossomos. Mas para o caráter PRE, foi detectado um número muito baixo de marcadores com significância, sendo estes localizados principalmente nos cromossomos 1 e 9; os cromossomos 2, 4, 5, 7 e 10 não apresentaram nenhum marcador com significância para este coeficiente. Este resultado indica que para $\mathrm{AE}$ e $\mathrm{AP}$ os efeitos dominantes são os mais importantes, enquanto que para $\mathrm{PRE}$, esses efeitos são muito pouco significativos para sua manifestação (Tabelas 11, 16 e 17).

Para o coeficiente $\beta_{2}$ foi constatado um número expressivo de marcadores com significância para os três caracteres. Para AE e AP, os marcadores apresentando significância para $\beta_{2}$ estão localizados principalmente nos cromossomos 2, 5 e 10, enquanto que para PRE, eles estão principalmente nos cromossomos 2, 6 e 7. Para os caracteres AE e AP, os marcadores com significância para 0 coeficiente $\beta_{4}$ estão localizados principalmente nos cromossomos 3, 4, 5 e 9, enquanto que para PRE foram detectados apenas 3 marcadores com significância, localizados nos cromossomos 3,5 e 8 . Considerando os efeitos epistáticos conjuntamente, foram detectados 56 (40,00\%), $70(50,00 \%)$ e 27 (19,29\%) marcadores com significância para AE, AP e PRE, respectivamente. Nota-se que estes efeitos são de importância acentuada para AE e AP, mas de menor importância para PRE (Tabelas 11, 16 e 17).

Para o caráter $A E$ os valores dos coeficientes de regressão variaram de $-1,86 \mathrm{~cm}$ planta ${ }^{-1}$ a $0,67 \mathrm{~cm}$ planta ${ }^{-1}$ para $\beta_{1}$, sendo obtidos valores negativos para 36 marcadores e valores positivos para 9 marcadores; para $\beta_{2}$ a variação foi de $-0,31 \mathrm{~cm}^{\text {planta }^{-1}}$ a $0,41 \mathrm{~cm}_{\text {planta }}{ }^{-1}$, sendo 11 negativos e 17 positivos; 
para $\beta_{3}$ a variação foi de $-0,27 \mathrm{~cm}$ planta $^{-1}$ a $1,34 \mathrm{~cm}_{\text {planta }}{ }^{-1}$, sendo 2 negativos e 72 positivos; para $\beta_{4}$ a variação foi de $-0,35 \mathrm{~cm}_{\text {planta }}{ }^{-1}$ a $0,26 \mathrm{~cm}_{\text {planta }}{ }^{-1}$, sendo 19 negativos e 9 positivos (Tabela 16).

Para o caráter AP os valores dos coeficientes de regressão variaram de $-2,18 \mathrm{~cm}$ planta $^{-1}$ a $1,45 \mathrm{~cm}$ planta ${ }^{-1}$ para $\beta_{1}$, sendo obtidos valores negativos para 39 marcadores e valores positivos para 19 marcadores; para $\beta_{2}$ a variação foi de $-0,37 \mathrm{~cm}_{\text {planta }}{ }^{-1}$ a $0,68 \mathrm{~cm}_{\text {planta }}{ }^{-1}$, sendo 12 negativos e 25 positivos; para $\beta_{3}$ a variação foi de $-0,44 \mathrm{~cm}_{\text {planta }}{ }^{-1}$ a $1,94 \mathrm{~cm}_{\text {planta }}{ }^{-1}$, sendo 1 negativo e 88 positivos; para $\beta_{4}$ a variação foi de $-0,48 \mathrm{~cm}_{\text {planta }}{ }^{-1}$ a $0,41 \mathrm{~cm}_{\text {planta }}{ }^{-1}$, sendo 17 negativos e 11 positivos (Tabela 16).

Para o caráter PRE os valores dos coeficientes de regressão variaram de $-4,60 \times 10^{-3} \mathrm{~cm}_{\text {planta }}{ }^{-1}$ a $2,40 \times 10^{-3} \mathrm{~cm}$ planta ${ }^{-1}$ para $\beta_{1}$, sendo obtidos valores negativos para 27 marcadores e valores positivos para 14 marcadores; para $\beta_{2}$ a variação foi de $-1,24 \times 10^{-3} \mathrm{~cm}$ planta $^{-1}$ a $1,00 \times 10^{-3} \mathrm{~cm}$ planta ${ }^{-1}$, sendo 11 negativos e 13 positivos; para $\beta_{3}$ a variação foi de $-0,66 \times 10^{-3} \mathrm{~cm}$ planta $^{-1}$ a $1,65 \times 10^{-3} \mathrm{~cm}^{-1 a n t a}{ }^{-1}$, sendo todos positivos; para $\beta_{4}$ a variação foi de $-0,43 \times 10^{-}$ ${ }^{3} \mathrm{~cm}_{\text {planta }}{ }^{-1}$ a $0,52 \times 10^{-3} \mathrm{~cm}_{\text {planta }}{ }^{-1}$, sendo 2 negativos e 1 positivo (tabela 17).

Nota-se uma grande similaridade entre os valores dos coeficientes para os caracteres $A E, A P$ e PRE, apesar do pequeno número de marcadores com significância para os coeficientes $\beta_{3}$ e $\beta_{4}$ detectados para o caráter PRE. Notase também, que a maior parte dos marcadores com significância para o coeficiente $\beta_{1}$ apresenta valor negativo para os três caracteres, evidenciando que a maioria dos alelos com efeitos aditivos favoráveis são provenientes da linhagem L-08-05. Para os três caracteres, a maior parte dos marcadores apresentaram valores positivos para o coeficiente $\beta_{3}$, indicando que os alelos da linhagem L-14-04 são dominantes com relação aos alelos da L-08-05.

Para os caracteres AE e AP, pode-se notar que os valores, em módulo, dos efeitos epistáticos são menores do que os valores dos efeitos aditivos e dominantes, isto é, $d>a>e$. Considerando os coeficientes com significâncias simultâneas, para a maioria dos marcadores a magnitude dos efeitos epistáticos é de apenas 2 a 4 vezes menor do que os efeitos aditivos e/ou dominantes. Esse resultado indica que para a manifestação destes caracteres, os efeitos epistáticos podem ser tão importantes quanto os demais. Entretanto, para o caráter PRE os valores, em módulo, dos efeitos têm a relação: a>e>d. Mas, o reduzido número de marcadores com significância para os efeitos dominantes 
(8) e epistáticos (27), e a falta de significâncias simultâneas para os coeficientes, limitou uma análise mais aprofundada (Tabelas 17 e 18).

Para o caráter $A E$ foram detectados 16 marcadores $(11,43 \%)$ que apresentaram pelo menos um efeito de interação contrastes por ambientes $\left(\sigma_{\beta I E}^{2}, \quad \sigma_{\beta 2 E}^{2}, \quad \sigma_{\beta 3 E}^{2}\right.$ e/ou $\left.\sigma_{\beta 4 E}^{2}\right)$ significativo. Foram detectados 12 marcadores com significância para $\sigma_{\beta I E}^{2}, 2$ marcadores com significância para $\sigma_{\beta 2 E}^{2}$ e 2 marcadores com significância para $\sigma_{\beta 4 E}^{2}$; não foi detectado marcador significativo para $\sigma_{\beta 3 E}^{2}$ (Tabela 16).

Para o caráter AP foram detectados 15 marcadores (10,71\%) que apresentaram pelo menos um efeito de interação contrastes por ambientes $\left(\sigma_{\beta I E}^{2}, \sigma_{\beta 2 E}^{2}, \sigma_{\beta 3 E}^{2}\right.$ e/ou $\left.\sigma_{\beta 4 E}^{2}\right)$ significativo. Foram detectados 9 marcadores com significância para $\sigma_{\beta 1 E}^{2}, 5$ marcadores com significância para $\sigma_{\beta 2 E}^{2}$ e 1 marcador com significância para $\sigma_{\beta 4 E}^{2} ; 1$ marcador foi simultaneamente significativo para $\sigma_{\beta 2 E}^{2}$ e $\sigma_{\beta 4 E}^{2}$; não foi detectado marcador significativo para $\sigma_{\beta 3 E}^{2}$ (Tabela 16).

Para o caráter PRE foram detectados 23 marcadores (16,43\%) que apresentaram pelo menos um efeito de interação contrastes por ambientes $\left(\sigma_{\beta 1 E}^{2}, \quad \sigma_{\beta 2 E}^{2}, \quad \sigma_{\beta 3 E}^{2}\right.$ e/ou $\left.\sigma_{\beta 4 E}^{2}\right)$ significativo. Foram detectados 13 marcadores com significância para $\sigma_{\beta 1 E}^{2}, 9$ marcadores com significância para $\sigma_{\beta 2 E}^{2}$ e 1 marcador com significância para $\sigma_{\beta 4 E}^{2}$; não foi detectado marcador significativo para $\sigma_{\beta 3 E}^{2}$ (Tabela 17).

Em resumo, os caracteres AE e AP apresentaram-se muito similares entre si, mas apresentaram algumas diferenças com relação ao caráter PRE. Foi detectado um pequeno número de marcadores com efeitos dominantes para o caráter PRE, sendo ausentes para os cromossomos 2, 4, 5, 7 e 10. Nesses mesmos cromossomos foi detectado um grande número de marcadores com significância para os efeitos dominantes para os caracteres AE e AP. Nota-se também, que os efeitos epistáticos para $\beta_{4}$ seguiram a mesma tendência, isto é, foi detectado um número pequeno de marcadores com significância para o caráter PRE, enquanto esse número foi bem maior para os caracteres AE e AP. Os resultados obtidos indicam que os caracteres $A E$ e $A P$ são muito 
influenciados por efeitos dominantes e epistáticos, enquanto que o caráter PRE é mais influenciado por efeitos aditivos e epistáticos. Indicam também que para os três caracteres, a maioria dos alelos com efeitos aditivos favoráveis são oriundos da linhagem L-08-05, enquanto que a maioria dos alelos com efeitos dominantes positivos são oriundos da linhagem L-14-04. Para a interação constrastes por ambientes, considerando os três caracteres, foi detectada maior porcentagem de marcadores com significância para os efeitos $\sigma_{\beta 1 E}^{2}$, seguidos pelo $\sigma_{\beta 2 E}^{2}$.

Os resultados obtidos por Cokerham \& Zeng (1996) também apresentaram grande similaridade entre os caracteres AE e AP. Para o caráter AE, esses autores obtiveram 75,34\%, 46,57\%, 73,97\%, e 27,40\% marcadores com significância para $\beta_{1}, \beta_{2}, \beta_{3}$ e $\beta_{4}$, respectivamente. Para o caráter AP foram detectados $63,01 \%, 42,47 \%, 87,67 \%$, e $16,44 \%$ marcadores com significância para $\beta_{1}, \beta_{2}, \beta_{3}$ e $\beta_{4}$, respectivamente.

Cokerham \& Zeng (1996) relataram que para o caráter $A E, 2,74 \%$ dos marcadores foram significativos para $\sigma_{\beta 1 E}^{2}$, enquanto que para o caráter AP, $1,37 \%$ dos marcadores foram significativos para $\sigma_{\beta I E}^{2}$. Para os outros efeitos de interação contraste por ambiente não foram detectados marcadores com significâncias. Esses resultados indicam que interações por ambiente praticamente não foram detectadas para estes caracteres.

Nota-se que, em geral, as porcentagens encontradas por estes autores para os caracteres AE e AP são maiores do que as apresentadas neste trabalho. Diferenças também foram detectadas quanto à magnitude e sinais dos coeficientes. Isto pode ser devido ao menor número de marcadores utilizados naquele trabalho e, também, à diferença de origem e de variabilidade entre os materiais genéticos adotados em ambos os trabalhos.

Os resultados apresentados neste trabalho indicam um pequeno grau de interação genótipos por ambientes, sendo maior do que o detectado por Cockerham \& Zeng (1996), podendo ser devido às condições tropicais de cultivo. O menor número de marcadores utilizados por estes autores e a diferença entre os materiais genéticos, de clima temperado e de clima tropical, podem ter contribuído para a obtenção desses resultados. 


\subsubsection{Florescimento feminino, masculino e intervalo de florescimento}

Para os caracteres FF, FM e IF, foram detectados 120 (85,71\%), 109 $(77,86 \%)$ e $69(49,29 \%)$ marcadores que apresentaram pelo menos um dos coeficientes ou efeitos $\left(\beta_{1}, \beta_{2}, \beta_{3}, \beta_{4}, \sigma_{\beta 1 E}^{2}, \sigma_{\beta 2 E}^{2}, \sigma_{\beta 3 E}^{2}\right.$ e/ou $\left.\sigma_{\beta 4 E}^{2}\right)$ significativo. Para o caráter FF foram detectados 78 (55,71\%), $43(30,71 \%), 53$ $(37,86 \%)$, e $24(17,14 \%)$ marcadores com significância para $\beta_{1}, \beta_{2}, \beta_{3}$ e $\beta_{4}$, respectivamente. Para o caráter FM foram detectados 62 (44,29\%), 41 $(29,29 \%), 53(37,86 \%)$, e 24 (17,14\%) marcadores com significância para $\beta_{1}, \beta_{2}$, $\beta_{3}$ e $\beta_{4}$, respectivamente. Para o caráter IF foram detectados $30(21,43 \%), 14$ (10,00\%), 21 (15,00\%), e $8(5,71 \%)$ marcadores com significância para $\beta_{1}, \beta_{2}$, $\beta_{3}$ e $\beta_{4}$, respectivamente (Tabelas 12, 17 e 18).

Para os três caracteres relacionados ao florescimento, o número de marcadores com significância para o coeficiente $\beta_{1}$ foi maior do que para os demais coeficientes, indicando que estes caracteres são muito influenciados pelos efeitos aditivos. Para os caracteres FF e FM foram detectados marcadores com significância para esse coeficiente em todos os cromossomos, com menor freqüência nos cromossomos 4, 6, 7 e 8. Para o caráter IF, no entanto, a maior freqüência de marcadores com significância para o coeficiente $\beta_{1}$ está justamente nesses cromossomos, 4, 6, 7 e 8. Então, quanto à distribuição genômica dos efeitos aditivos, pode-se notar a presença de similaridade entre os caracteres $\mathrm{FF}$ e $\mathrm{FM}$ e grande dissimilaridade entre $\mathrm{O}$ caráter IF e os caracteres FF e FM (Tabelas 12, 17 e 18).

Considerando os caracteres FF e FM, foram detectados marcadores com significância para o coeficiente $\beta_{3}$ em todos os cromossomos, com maior freqüência para os cromossomos $1,5,6,7$ e 10. Para o caráter $I F$, os marcadores com esses coeficientes significativos estão localizados principalmente nos cromossomos 2 e 10, enquanto que os cromossomos 1 , 3 e 7 , nenhum marcador com significância para este coeficiente foi detectado. Notase mais uma vez, uma dissimilaridade entre o caráter IF e os caracteres FF e FM. Também, para os caracteres FF e FM, os efeitos aditivos são mais importantes do que os efeitos dominantes e epistáticos, enquanto que, para o caráter IF, os efeitos aditivos são mais importantes do que os efeitos dominantes e epistáticos. Além do mais, para o caráter IF, o número de marcadores com significância para $\beta_{3}$ é pequeno, além da maioria estar 
concentrada em duas regiões cromossômicas com marcadores muito próximos entre si.

Para os caracteres FF e FM, foram detectados marcadores com significância para $\beta_{2}$ em todos os cromossomos e, principalmente, nos cromossomos 1, 2 e 4. Para o caráter IF, os marcadores com significância para $\beta_{2}$ estão localizados principalmente nos cromossomos 3 e 4 . Para o efeito $\beta_{4}$, foram detectados marcadores com significância principalmente nos cromossomos 2, 4 e 5 para os caracteres FF e FM, e principalmente nos cromossomos 2 e 4 para o caráter IF. Considerando os efeitos epistáticos conjuntamente, foram detectados 63 (45,00\%), 56 (40,00\%) e 19 (13,57\%) dos marcadores com significância para os caracteres FF, FM e IF, respectivamente. Pode-se notar que o número de marcadores que detectaram efeitos epistáticos para os caracteres FF e FM é cerca de 3 vezes maior do que o número de marcadores para o caráter IF.

Os valores dos coeficientes $\beta_{1}$ para o caráter FF variaram entre $-27,55 \times$ $10^{-2}$ dias a $44,64 \times 10^{-2}$ dias, sendo obtidos valores negativos para 27 marcadores e valores positivos para 51 marcadores; os coeficientes $\beta_{2}$ variaram de $-8,37 \times 10^{-2}$ dias a $12,61 \times 10^{-2}$ dias, sendo 21 negativos e 22 positivos; os coeficientes $\beta_{3}$ variaram de $-40,43 \times 10^{-2}$ dias a $3,70 \times 10^{-2}$ dias, sendo 52 negativos e 1 positivo; os coeficientes $\beta_{4}$ variaram de $-5,49 \times 10^{-2}$ dias a 6,60 $x$ $10^{-2}$ dias, sendo 8 negativos e 16 positivos.

Os valores dos coeficentes $\beta_{1}$ para o caráter FM variaram de $-24,46 \times$ $10^{-2}$ dias a $42,91 \times 10^{-2}$ dias, sendo obtidos valores negativos para 27 marcadores e valores positivos para 35 marcadores; os coeficientes $\beta_{2}$ variaram de $-6,74 \times 10^{-2}$ dias a $7,74 \times 10^{-2}$ dias, sendo 17 negativos e 24 positivos; os coeficientes $\beta_{3}$ variaram de $-27,11 \times 10^{-2}$ dias a $8,67 \times 10^{-2}$ dias, sendo 49 negativos e 4 positivos; os coeficientes $\beta_{4}$ variaram de $-4,23 \times 10^{-2}$ dias a $4,92 \times$ $10^{-2}$ dias, sendo 10 negativos e 14 positivos.

Os valores dos coeficientes $\beta_{1}$ para o caráter IF variaram de $-14,39 \times 10^{-2}$ dias a $7,58 \times 10^{-2}$ dias, sendo obtidos valores positivos para 9 marcadores e valores negativos para 21 marcadores; os coeficientes $\beta_{2}$ variaram de $-4,87 x$ $10^{-2}$ dias a $3,32 \times 10^{-2}$ dias, sendo 6 negativos e 8 positivos; os coeficientes $\beta_{3}$ variaram de $4,14 \times 10^{-2}$ dias a $13,71 \times 10^{-2}$ dias, sendo obtidos valores positivos 
para todos os 21 marcadores; os coeficientes $\beta_{4}$ variaram de $-2,90 \times 10^{-2}$ dias a $2,93 \times 10^{-2}$ dias, sendo 5 negativos e 3 positivos.

Os resultados obtidos indicam que os caracteres FF e FM são muito influenciados por efeitos aditivos e epistáticos, enquanto que o caráter IF é influenciado, principalmente, por efeitos aditivos. Para os caracteres FF e FM a maior parte dos marcadores apresenta valores positivos para o coeficiente $\beta_{1} \mathrm{e}$, portanto, a maioria dos alelos com efeitos aditivos favoráveis são oriundos da linhagem L-14-04, enquanto que para o caráter IF a maior parte desses alelos são oriundos da linhagem L-08-05. Os alelos com efeitos dominantes favoráveis são, em sua quase totalidade, oriundos alelos da linhagem L-08-05 para os caracteres FF e FM, e da linhagem L-14-04 para o caráter IF.

Para os três caracteres, considerando os valores dos efeitos em módulo, pode-se notar que $a>d>e$. A magnitude dos efeitos aditivos e dominantes, para a maioria dos marcadores, é apenas 2 a 4 vezes maior do que a magnitude dos efeitos epistáticos. Esse resultado indica que para a manifestação destes caracteres, os efeitos epistáticos podem ser tão importantes quanto os outros efeitos. (Tabelas 12, 17 e 18).

Para o caráter FF, foram detectados apenas 3 marcadores $(2,14 \%)$ que apresentaram significância para $\sigma_{\beta 1 E}^{2}$, localizados nos cromossomos 1,5 e 8 . Para o caráter FM foram detectados apenas 2 marcadores $(1,43 \%)$ que apresentaram efeito significativo para $\sigma_{\beta I E}^{2}$, localizados nos cromossomos $1 \mathrm{e}$ 8. Para o caráter IF, foram detectados 15 marcadores $(10,71 \%)$ que apresentaram pelo menos um efeito significativo para $\sigma_{\beta 1 E}^{2}, \sigma_{\beta 2 E}^{2}$ e $\sigma_{\beta 3 E}^{2}: 10$ marcadores com significância para $\sigma_{\beta I E}^{2} ; 5$ marcadores com significância para $\sigma_{\beta 2 E}^{2}$; e 1 marcador com significância para $\sigma_{\beta 3 E}^{2}$; não foi detectado significância para $\sigma_{\beta 4 E}^{2}$; um marcador apresentou significância simultânea para os efeitos $\sigma_{\beta I E}^{2}$ e $\sigma_{\beta 3 E}^{2}$ (Tabelas 17 e 18).

Cokerham \& Zeng (1996) apresentaram, para o caráter FM, 42,47\%, $23,29 \%, 53,42 \%$, e $15,07 \%$ dos marcadores com significância para $\beta_{1}, \beta_{2}, \beta_{3}$ e $\beta_{4}$, respectivamente. Entretanto, estes autores encontraram grande porcentagem de marcadores com efeitos da interação contrastes por ambiente significativos. Foram detectados $63,01 \%, 56,16 \%, 35,62 \%$, e $31,51 \%$ 
marcadores com significância para $\sigma_{\beta I E}^{2}, \quad \sigma_{\beta 2 E}^{2}, \quad \sigma_{\beta 3 E}^{2}$ e $\sigma_{\beta 4 E}^{2}$, respectivamente.

Considerando apenas os efeitos $\beta_{1}, \beta_{2}, \beta_{3}$, e $\beta_{4}$ obtidos neste trabalho, pode-se notar que as porcentagens de marcadores com significância é maior do que a apresentada por Cockerham \& Zeng (1996). Entretanto, considerando apenas a porcentagem de marcadores com significância para interação de contrastes por ambientes, $\sigma_{\beta 1 E}^{2}, \sigma_{\beta 2 E}^{2}, \sigma_{\beta 3 E}^{2}$ e $\sigma_{\beta 4 E}^{2}$, os valores encontrados por estes autores são maiores do que os encontrados neste trabalho. Esses resultados indicam: 1) neste trabalho foi detectado maior porcentagem de marcadores com significância para $\beta_{1}, \beta_{2}, \beta_{3}$ e $\beta_{4}$, e, portanto, maior número de QTLs não afetados pelo ambiente; 2) que as diferenças entre os ambientes utilizados pelos autores citados são maiores do que as diferenças entre os ambientes utilizados para este trabalho; 3 ) que os materiais genéticos avaliados neste trabalho tiveram menor interação com ambientes.

\subsubsection{Número de folhas}

Para o caráter número de folhas acima da primeira espiga (NF), foram detectados 120 locos $(85,71 \%)$ marcadores que apresentaram pelo menos um coeficiente $\left(\beta_{1}, \beta_{2}, \beta_{3}\right.$ ou $\left.\beta_{4}\right)$ significativo. Não se detectou marcador com efeito contraste por ambientes $\left(\sigma_{\beta 1 E}^{2}, \sigma_{\beta 2 E}^{2}, \sigma_{\beta 3 E}^{2}\right.$ e/ou $\left.\sigma_{\beta 4 E}^{2}\right)$ significativo. Foram detectados 75 (53,57\%), 61 (43,57\%), 36 (25,71\%), e 18 (12,86\%) marcadores com significância para $\beta_{1}, \beta_{2}, \beta_{3}$ e $\beta_{4}$, respectivamente (Tabelas 13 e 19).

A grande proporção de marcadores com significância para o coeficiente $\beta_{1}$ detectados para NF indica que, para a manifestação deste caráter, os efeitos aditivos possuem função importante. Foram detectados marcadores com significância para esse coeficiente em todos os cromossomos, sendo mais freqüentemente encontrados nos cromossomos 1, 2 e 5 (Tabelas 13 e 19).

Para o coeficiente $\beta_{3}$ foi detectado um número relativamente pequeno de marcadores com significância, comparado ao número detectado para os coeficientes $\beta_{1}, \beta_{2}$ e $\beta_{4}$, evidenciando que os efeitos dominantes podem não ser tão importantes quanto os efeitos aditivos e epistáticos para a manifestação do 
caráter NF. Os cromossomos 1, 2 e 5 apresentaram maior freqüência de marcadores significativos para os efeitos dominantes (Tabelas 13 e 19).

Para os efeitos epistáticos, foi detectado um número maior de marcadores com significância para $\beta_{2}$ do que para $\beta_{4}$, evidenciando que os efeitos aditivos $x$ aditivos e dominantes $x$ dominantes são mais presentes do que os efeitos aditivos $x$ dominantes e dominantes $x$ aditivos. Os marcadores com significância para $\beta_{2}$ estão em sua maior parte, localizados nos cromossomos $1,2,4,5,6$ e 7 . Para $\beta_{4}$ os marcadores foram detectados principalmente nos cromossomos 3, 5 e 9 . Considerando os efeitos epistáticos conjuntamente, foram detectados 8 locos marcadores que apresentaram simultaneamente significância para os efeitos $\beta_{2}$ e $\beta_{4}$. Assim, 71 marcadores $(50,71 \%)$ apresentaram significância para os coeficientes $\beta_{2}$ e/ou $\beta_{4}$ (efeitos epistáticos), indicando que esses efeitos são tão importantes quanto os efeitos aditivos para a manifestação deste caráter (Tabelas 13 e 19).

Os valores dos coeficientes de regressão variaram de $-9,50 \times 10^{-2}$ folhas planta $^{-1}$ a $9,28 \times 10^{-2}$ folhas planta ${ }^{-1}$ para $\beta_{1}$, sendo obtidos valores negativos para 31 marcadores e valores positivos para 44 marcadores; para $\beta_{2}$ a variação foi de $-2,10 \times 10^{-2}$ folhas planta ${ }^{-1}$ a $1,61 \times 10^{-2}$ folhas planta ${ }^{-1}$, sendo 31 negativos e 15 positivos; para $\beta_{3}$ a variação foi de $-1,45 \times 10^{-2}$ folhas planta $^{-1}$ a $4,53 \times 10^{-2}$ folhas planta ${ }^{-1}$, sendo 2 negativos e 34 positivos; para $\beta_{4}$ a variação foi de $-1,03 \times 10^{-2}$ folhas planta ${ }^{-1}$ a $1,07 \times 10^{-2}$ folhas planta ${ }^{-1}$, sendo 13 negativos e 5 positivos (Tabelas 19).

Pode-se notar que, de forma geral, a magnitude dos efeitos aditivos $\left(\beta_{1}\right)$ é maior do que a magnitude dos efeitos dominantes $\left(\beta_{3}\right)$, que por sua vez, são maiores do que os efeitos epistáticos $\left(\beta_{2}+\beta_{4}\right)$. Em outras palavras, a>d>e. Entretanto, os valores dos coeficientes $\beta_{2}$ e $\beta_{4}$ são, para a maioria dos marcadores, de 1 a 3 vezes menores do que os valores dos coeficientes $\beta_{1}$ e/ou $\beta_{3}$, acentuando ainda mais a importância dos efeitos epistáticos para a manifestação desse caráter (Tabelas 13 e 19).

De forma geral, os efeitos aditivos foram importantes para a manifestação do caráter NF, sendo detectados marcadores com significância para $\beta_{1}$ em todos os cromossomos. A magnitude dos coeficientes $\beta_{1}$ é maior do que as magnitudes dos outros coeficientes. Os efeitos epistáticos também foram importantes para este caráter, sendo detectados em maior número nos 
cromossomos 2, 4, 5 e 6. A importância dos efeitos epistáticos é ainda, acentuada pela magnitude em módulo de seus valores. Os efeitos dominantes não foram tão importantes quanto os efeitos aditivos e epistáticos, sendo que os cromossomos 1, 2 e 5 apresentaram maior freqüência de marcadores com significância para esse efeito.

\subsubsection{Teor de umidade nos grãos}

Para o caráter teor de umidade nos grãos (UM), foram detectados 72 $(51,43 \%)$ marcadores que apresentaram pelo menos um dos coeficientes ou efeitos $\left(\beta_{1}, \beta_{2}, \beta_{3}, \beta_{4}, \sigma_{\beta 1 E}^{2}, \sigma_{\beta 2 E}^{2}, \sigma_{\beta 3 E}^{2}\right.$ e/ou $\left.\sigma_{\beta 4 E}^{2}\right)$ significativo. Foram detectados 25 (17,86\%), 9 (6,43\%), 17 (12,14\%), e 6 (4,29\%) marcadores com significância para $\beta_{1}, \beta_{2}, \beta_{3}$ e $\beta_{4}$, respectivamente (Tabelas 14 e 19).

Para este caráter foi detectado maior número de marcadores com significância para $\beta_{1}$ do que para os outros coeficientes, evidenciando a maior importância dos efeitos aditivos para a manifestação do caráter UM. Todos os cromossomos apresentaram pelo menos um marcador com significância para esse coeficiente, sendo detectado maior número nos cromossomos 1 , 2 e 4 (Tabelas 14 e 19).

Para o coeficiente $\beta_{3}$ foram detectados uma pequena porcentagem de marcadores com significância, indicando que os efeitos dominantes não devem ser importantes para a manifestação deste caráter. A maior parte destes marcadores está localizada nos cromossomos 4, 5 e 10, enquanto que os cromossomos 2, 3, 7, 8 e 10 não apresentaram marcador com significância para este coeficiente (Tabelas 14 e 19).

Considerando os efeitos epistáticos, foram detectados 9 marcadores com significância para $\beta_{2}$ localizados principalmente nos cromossomos 1, 5 e 6 . Para $\beta_{4}$ foram detectados 6 marcadores, localizados principalmente nos cromossomos 3, 4, 8, 9 e 10. Nenhum marcador apresentou significância simultânea para $\beta_{2}$ e $\beta_{4}$. Assim, foram detectados 15 marcadores $(10,71 \%)$ que apresentaram significância para efeitos epistáticos, indicando que a epistasia não é muito importante para a manifestação deste caráter. 
Os valores dos coeficientes de regressão variaram de $-5,76 \times 10^{-2} \%$ a $4,90 \times 10^{-2} \%$ para $\beta_{1}$, sendo obtidos valores negativos para 11 marcadores e valores positivos para 14 marcadores; para $\beta_{2}$ a variação foi de $-2,68 \times 10^{-2} \%$ a $1,90 \times 10^{-2} \%$, sendo detectados 6 negativos e 3 positivos; para $\beta_{3}$ a variação foi de $-2,04 \times 10^{-2} \%$ a $3,68 \times 10^{-2} \%$, sendo 3 negativos e 14 positivos; para $\beta_{4}$ a vaiação a variação foi de $-0,59 \times 10^{-2} \%$ a $0,97 \times 10^{-2} \%$, sendo 4 positivos e 2 negativos. Como para a maioria dos caracteres avaliados neste trabalho, os valores, em módulo, dos efeitos aditivos foram maiores do que os efeitos dominantes e epistáticos, ou seja, a>d>e.

Para este caráter foi detectado um número expressivo de marcadores que apresentaram interações contrastes por ambientes. Foram obtidos 32 $(22,86 \%)$ locos marcadores que apresentaram pelo menos um efeito $\sigma_{\beta I E}^{2}$, $\sigma_{\beta 2 E}^{2}$ e/ou $\sigma_{\beta 3 E}^{2}$ significativo, sendo 19 (13,57\%), 14 (10,00\%), 3 (2,14\%), marcadores com significância para $\sigma_{\beta 1 E}^{2}, \sigma_{\beta 2 E}^{2}$ e $\sigma_{\beta 3 E}^{2}$, respectivamente; não foram detectados marcadores com significância para $\sigma_{\beta 4 E}^{2}$. Nota-se que, além de não apresentar muitos marcadores com significância dos efeitos para os contrastes, este caráter também apresenta um elevado número de marcadores com significância dos efeitos das interações dos contrastes por ambientes.

Em resumo, foi detectado um número pequeno de marcadores com significância para os coeficientes $\beta_{1}, \beta_{2}, \beta_{3}$ e $\beta_{4}$ para esse caráter. Por outro lado, foi detectado um número relativamente grande de efeitos das interações contrastes por ambientes. Em todo caso, a significância para os efeitos aditivos e aditivos por ambiente $\left(\beta_{1}\right.$ e $\left.\sigma_{\beta I E}^{2}\right)$ foi preponderante. Esse resultado evidencia que para a manifestação desse caráter os efeitos aditivos, ou suas interações com ambientes, são os mais importantes. Entretanto, os resultados também evidenciam a pequena variabilidade genética para este caráter, uma vez que foram detectados um número relativamente pequeno (72) de marcadores com qualquer tipo de significância.

Cockerham \& Zeng (1996) detectaram 4,11\%, 9,59\%, 9,59\% e 1,37\% marcadores com significância para $\beta_{1}, \beta_{2}, \beta_{3}$ e $\beta_{4}$, respectivamente, e $58,90 \%$, $17,81 \%, 4,4 \%$ e $1,37 \%$ marcadores com significância para $\sigma_{\beta 1 E}^{2}, \sigma_{\beta 2 E}^{2}, \sigma_{\beta 3 E}^{2}$ e $\sigma_{\beta 4 E}^{2}$, respectivamente. Nota-se a grande porcentagem de marcadores com 
significância para $\sigma_{\beta 1 E}^{2}$ encontrados por estes autores, o que indica que existe um grande número de QTLs com efeitos aditivos que são muito influenciados pelo ambiente.

\subsection{Considerações finais}

O mapa genético foi obtido com 140 marcadores moleculares do tipo microssatélites, mas a distribuição desses marcadores pelo genoma não foi uniforme. Há regiões mais saturadas que outras, sendo que os maiores problemas foram detectados nos cromossomos 2, 4, 5 e 10, onde existem regiões pouco saturadas, com intervalos variando de 40 a $78 \mathrm{cM}$. Essas regiões não foram saturadas pela falta de primers de microssatélites polimórficos e/ou distorções de segregação genotípica. Entretanto, existe uma constante e periódica divulgação de novos primers em páginas da internet, o que poderá fornecer os marcadores necessários para sanar esse problema e, conseqüentemente, melhorar a saturação do mapa obtido.

Este trabalho visou o estudo de diversos caracteres quantitativos em milho utilizando o delineamento III (Comstock \& Robinson, 1952). Este delineamento permite obter estimativas dos componentes da variância genética e do grau médio de dominância. Cockerham \& Zeng (1996) propuseram uma modificação deste delineamento para a análise genética estatística de marcadores moleculares, incluindo ligação genética, epistasia de dois locos e parentais $F_{3}$. Dessa forma tornou-se possível a detecção de regiões cromossômicas com locos que afetam a expressão fenotípica de caracteres quantitativos (QTLs) e os efeitos aditivos, dominantes e epistáticos destes. Enquanto as médias e os componentes de variância genética são funções da soma dos efeitos de todos os locos, o uso do delineamento III com marcadores moleculares permite determinar os efeitos específicos de regiões cromossômicas com QTLs, a magnitude dos efeitos genéticos e sua distribuição no genoma.

Neste trabalho, as estimativas dos componentes da variância genética $\left(\hat{\sigma}_{G}^{2}\right)$ mostraram que as linhagens parentais são divergentes para todos os caracteres avaliados, o que permitiu a liberação da variância aditiva de elevada 
magnitude. Da mesma forma, a estimativa da variância genética aditiva $\left(\hat{\sigma}_{A}^{2}\right)$ apresentou valores elevados para todos os caracteres. Este fato pode ser atribuído à divergência das linhagens, visto que estas são originadas de grupos heteróticos distintos. Assim, todos os caracteres avaliados apresentaram magnitudes elevadas de respostas à seleção e, consequentemente, esta população apresenta elevado potencial para o melhoramento genético.

O caráter principal, produção de grãos (PG), apresentou elevadas magnitudes de correlação genética aditiva com os demais caracteres avaliados, exceto com os caracteres PRE, IF, NF e UM. Este resultado demonstra a necessidade de construção de índices de seleção adequados para o melhoramento deste caráter.

A análise do delineamento III com marcadores moleculares mostrou que, para todos os caracteres avaliados, foram detectados marcadores com efeitos significativos em todos os cromossomos. Isso demonstra que os QTLs desses caracteres estão distribuídos por todo o genoma do milho. Para o caráter principal, PG, o número de marcadores com significância para os efeitos de dominância foram superiores aos dos efeitos aditivos. Entretanto, os efeitos epistáticos apresentaram-se tão importantes quanto os demais efeitos na manifestação desse caráter, apresentando $32,14 \%$ dos marcadores apresentaram significância para este efeito. Para os demais caracteres foi detectado mais de $34 \%$ de marcadores dom significância para os efeitos epistáticos, exceto para PRE, IF e UM.

Considerando a magnitude dos coeficientes, em módulo, para o caráter produção de grãos, os efeitos dominantes apresentaram valores maiores do que os efeitos aditivos e epistáticos, isto é, $d>a>e$. Para os demais caracteres, os efeitos aditivos apresentaram valores superiores aos dos efeitos dominantes e epistáticos, a>d>e, excluindo o caráter PRE, para o qual foi encontrada a relação a>e>d. Entretanto, as magnitudes relativamente altas dos efeitos epistáticos se repetiram para todos os caracteres, indicando a importância acentuada desses efeitos para sua manifestação.

Dez marcadores apresentaram significância simultânea para todos os caracteres. Para os caracteres correlacionados $\left(\hat{r}_{G} \geq|0,5|\right)$ grande parte dos marcadores que apresentaram significância foram comuns a ambos os caracteres. Alguns pares de caracteres que apresentaram estimativas altas 
para correlação genética (como por exemplo, AP e AE, FF e FM) apresentaram grande parte dos marcadores com significância em comum, enquanto outros pares com correlação genética baixa (como por exemplo PRE e IF, PRE e UM), apresentaram pequena parte dos marcadores com significância em comum. Também ocorreu que alguns pares de caracteres com correlação genética baixa (como por exemplo PG e NF, AP e FF) apresentaram grande parte dos marcadores com significância em comum. Esses resultados podem ser interpretados da seguinte forma: 1) os pares de caracteres com correlação elevada têm os locos comuns devido à pleiotropia ou à sua proximidade física; 2) os caracteres que possuem correlação baixa e alto número de locos em comum, podem ter locos próximos e ligados ao mesmo marcador, sendo que esses locos não estão relacionados entre si; 3) o desequilíbrio de ligação pode reduzir ou aumentar a correlação entre os caracteres.

A interação progênies por ambientes da análise de variância, foi significativa para quase todos os caracteres avaliados, sendo que três caracteres foram exceções (FF, IF e UM). Como esperado, o caráter PG apresentou elevada significância para esta interação, mas, surpreendentemente, foram detectadas apenas 7,14\% dos 140 marcadores com efeitos significativos para interação contrastes por ambientes e, de forma contrária, o caráter UM não apresentou significância para esta interação na análise de variância, mas apresentou $22,86 \%$ dos marcadores com significância para interação contrastes por ambientes. Evidentemente, as técnicas de análises são diferentes, o que pode levar a resultados diferentes; mas este aspecto merece mais investigações, pois os resultados não são claros. Verificase que, para todos os caracteres, foi detectado maior número de marcadores com significância para as interações contrastes por ambientes para os efeitos aditivos por ambiente, $\sigma_{\beta 1 E}^{2}$, seguidos pelos efeitos epistáticos, particularmente $\sigma_{\beta 2 E}^{2}$, e pelos efeitos dominantes, $\sigma_{\beta 3 E}^{2}$.

O modelo de análise de marcadores apresenta a qualidade de permitir a obtenção de estimativas de efeitos genéticos aditivos, dominantes e epistáticos e suas distribuições pelo genoma. Entretanto, trata-se de uma análise de marcas simples com suas limitações inerentes. Também, os efeitos epistáticos detectados referem-se a uma pequena fração dos efeitos existentes. Apesar 
disso, o modelo pode ser considerado razoavelmente adequado pelas informações que fornece. Espera-se que seja desenvolvido um modelo em que se utilize marcadores flanqueadores e cofatores para melhorar as informações deste tipo de análise. Portanto, acrescentando-se novos marcadores às regiões pouco saturadas do genoma e com um modelo melhor de análise, espera-se reanalizar estes dados em um futuro próximo, visando à obtenção de maior quantidade e qualidade de informações.

As análises apresentadas neste trabalho foram realizadas com germoplasma tropical. Quase todas as informações existentes na literatura foram obtidas para germoplasma de clima temperado, o que nem sempre pode ser transposto para as condições tropicais. Dessa forma, esse trabalho pode ajudar a discernir melhor os mecanismos genéticos que estão envolvidos na expressão dos caracteres avaliados nas condições tropicais. 


\section{CONCLUSÕES}

Os resultados obtidos no presente trabalho permitiram concluir que:

1 - As magnitudes das variâncias genética aditiva e genética dominante mostraram que a população apresenta elevada variabilidade genética, que é função da diversidade genética dos parentais. Os valores dos graus médios de dominância dos caracteres avaliados são similares aos reportados para milho temperado;

2 - O mapa genético possui 140 marcadores moleculares microssatélites, os quais mapearam uma extensão de $1.730,1 \mathrm{cM}$, sendo $12,4 \mathrm{cM}$ de intervalo médio entre marcadores.

3 - Para todos os caracteres foram detectados QTLs em todos os cromossomos, demonstrando que os locos que controlam estes caracteres estão distribuídos pelo genoma, o que também foi reportado para milho temperado;

4 - Os caracteres PG, PRO, AE e AP apresentaram maior número de marcadores com significância para efeitos dominantes, enquanto que os outros caracteres apresentaram maior número de marcadores para efeitos aditivos. Considerando a magnitude em módulo dos coeficientes, os efeitos dominantes apresentaram-se maiores para PG, enquanto que os efeitos aditivos apresentaram valores maiores para os outros caracteres. Os efeitos epistáticos foram importantes para a manifestação de todos os caracteres entretanto, os valores de seus coeficientes foram menores do que os valores aditivos e dominantes, exceto para o caráter PRE. 
5 - Para a maioria dos caracteres detectou-se pequeno número de marcadores com significância para interações contrastes por ambientes, com exceção dos caracteres NF, FF e FM, para os quais praticamente não foram detectadas estas interações. Os efeitos aditivos dos QTLs apresentaram maior número de marcadores com significância para interações com ambientes, seguidos dos efeitos epistáticos e dominantes.

6 - Os efeitos dos QTLs para todos os caracteres variaram muito em magnitude e sinal entre marcadores, mostrando que os QTLs contribuem de forma diferenciada para as expressões destes caracteres. 


\section{ANEXOS:}

Tabelas (6 a 19) de Resultados e Discussão 


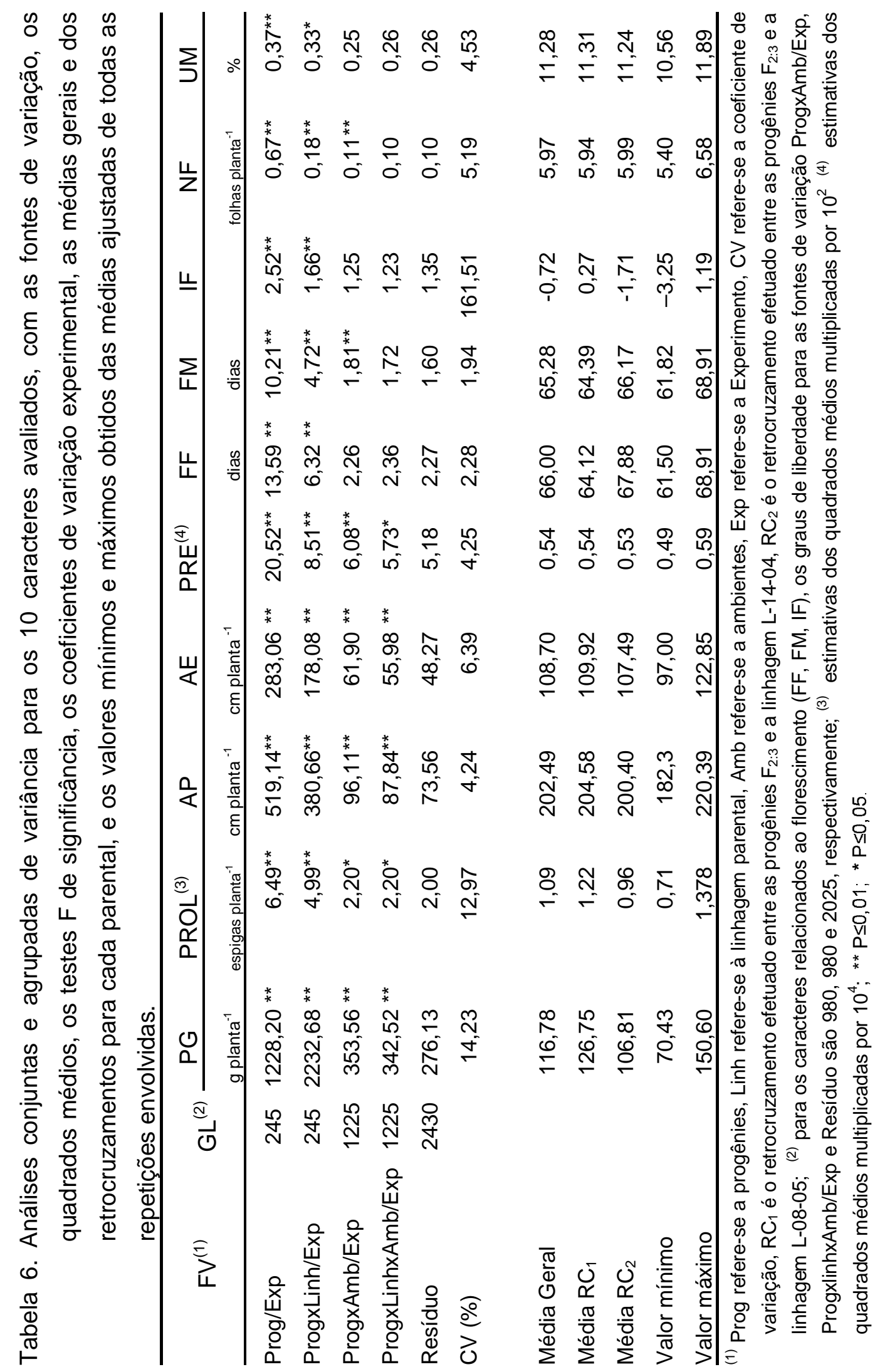




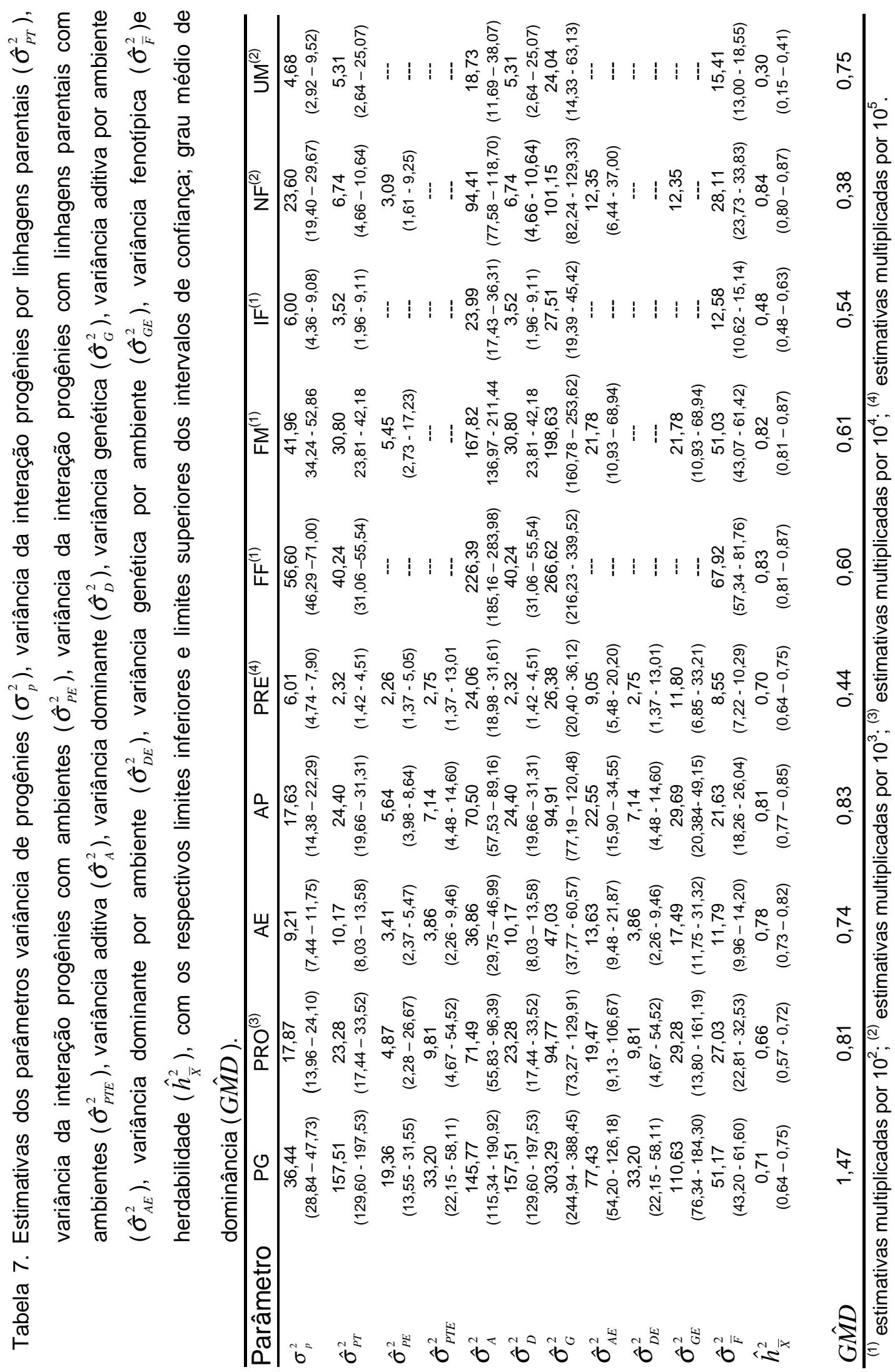


Tabela 8. Estimativas dos coeficientes de correlação aditiva $\left(\hat{r}_{A}\right)$, genética $\left(\hat{r}_{G}\right)$ e fenotípica $\left(\hat{r}_{F}\right)$ com sua respectiva significância obtida pelo teste t.

\begin{tabular}{|c|c|c|c|}
\hline Caracteres & $\hat{r}_{A}$ & $\hat{r}_{G}$ & $\hat{r}_{F}$ \\
\hline PGxPRO & 0,51 & 0,56 & $0,46^{* *}$ \\
\hline PGXAE & 0,52 & 0,60 & $0,45^{* *}$ \\
\hline PGXAP & 0,47 & 0,59 & $0,41^{* *}$ \\
\hline PGXPRE & 0,33 & 0,31 & $0,27^{\text {** }}$ \\
\hline PGxFF & $-0,64$ & $-0,65$ & $-0,55^{\star *}$ \\
\hline PGxFM & $-0,60$ & $-0,59$ & $-0,52^{* *}$ \\
\hline PGxIF & 0,36 & 0,40 & $0,24^{* *}$ \\
\hline PGXNF & $-0,05$ & 0,07 & $-0,02$ \\
\hline PGxUM & 0,26 & 0,26 & 0,13 \\
\hline PROXAE & 0,30 & 0,35 & $0,19^{* *}$ \\
\hline PROXAP & 0,24 & 0,32 & $0,15^{\star}$ \\
\hline PROXPRE & 0,23 & 0,22 & 0,14 \\
\hline PROxFF & $-0,47$ & $-0,51$ & $-0,39^{* *}$ \\
\hline PROxFM & $-0,38$ & $-0,42$ & $-0,32^{* *}$ \\
\hline PROXIF & 0,43 & 0,45 & $0,27^{\star *}$ \\
\hline PROXNF & $-0,27$ & $-0,15$ & $-0,17^{*}$ \\
\hline PROXUM & 0,33 & 0,30 & 0,14 \\
\hline AExAP & 0,88 & 0,90 & $0,85^{\text {** }}$ \\
\hline AExPRE & 0,71 & 0,69 & $0,71^{\text {** }}$ \\
\hline AExFF & $-0,04$ & $-0,14$ & $-0,05$ \\
\hline AExFM & 0,06 & $-0,05$ & 0,03 \\
\hline AExIF & 0,26 & 0,29 & $0,17^{\star}$ \\
\hline AExNF & $-0,16$ & $-0,09$ & $-0,12$ \\
\hline AExUM & $-0,06$ & $-0,02$ & $-0,01$ \\
\hline APXPRE & 0,24 & 0,26 & $0,22^{* *}$ \\
\hline APxFF & $-0,04$ & $-0,16$ & 0,06 \\
\hline APXFM & 0,06 & $-0,05$ & 0,03 \\
\hline APXIF & 0,29 & 0,33 & $0,19^{\text {** }}$ \\
\hline APXNF & 0,16 & 0,20 & $0,16^{*}$ \\
\hline APXUM & 0,06 & 0,09 & 0,04 \\
\hline PRExFF & $-0,01$ & $-0,04$ & $-0,01$ \\
\hline PRExFM & 0,02 & $-0,02$ & 0,01 \\
\hline PRExIF & 0,08 & 0,08 & 0,06 \\
\hline PRExNF & $-0,52$ & $-0,50$ & $-0,43^{\star *}$ \\
\hline PREXUM & $-0,19$ & $-0,18$ & $-0,07$ \\
\hline FFxFM & 0,94 & 0,94 & $0,90^{* *}$ \\
\hline FFxIF & $-0,53$ & $-0,53$ & $-0,50^{* *}$ \\
\hline FFxNF & 0,15 & 0,10 & 0,11 \\
\hline FFxUM & 0,15 & 0,11 & 0,06 \\
\hline FMxIF & $-0,22$ & $-0,22$ & $-0,08$ \\
\hline FMxNF & 0,10 & 0,07 & 0,07 \\
\hline FMxUM & 0,11 & 0,10 & 0,04 \\
\hline IFxNF & $-0,18$ & $-0,12$ & $-0,11$ \\
\hline IFxUM & $-0,18$ & $-0,08$ & $-0,06$ \\
\hline NFxUM & 0,32 & 0,33 & $0,15^{\star}$ \\
\hline
\end{tabular}

${ }^{* *} \mathrm{P} \leq 0,01 ;{ }^{*} \mathrm{P} \leq 0,05$. 
Tabela 9. Número de marcadores com significância para os efeitos $\beta_{1} \beta_{2} \beta_{3}$ e $\beta_{4}$ em cada cromossomo para o caráter peso de grãos (PG).

\begin{tabular}{|c|c|c|c|c|c|c|c|c|c|c|c|}
\hline \multirow{2}{*}{$\begin{array}{l}\text { Cromossomo } \\
\left.\text { (marcadores }^{(1)}\right)\end{array}$} & \multicolumn{4}{|c|}{$\begin{array}{l}\text { Coeficientes } \\
\text { significativos }\end{array}$} & \multicolumn{6}{|c|}{$\begin{array}{c}\text { Coeficientes simultaneamente } \\
\text { significativos }\end{array}$} & \multirow[t]{2}{*}{ Total $^{(2)}$} \\
\hline & $\beta_{1}$ & $\beta_{2}$ & $\beta_{3}$ & $\beta_{4}$ & $\beta_{1} \beta_{2}$ & $\beta_{1} \beta_{3}$ & $\beta_{1} \beta_{4}$ & $\beta_{2} \beta_{3}$ & $\beta_{2} \beta_{4}$ & $\beta_{3} \beta_{4}$ & \\
\hline $1(19)$ & 11 & 4 & 17 & 6 & 3 & 10 & 3 & 4 & 3 & 6 & 18 \\
\hline 2 (19) & 6 & 1 & 16 & 3 & 1 & 6 & 1 & 1 & 0 & 2 & 17 \\
\hline $3(13)$ & 6 & 1 & 6 & 3 & 1 & 2 & 1 & 0 & 0 & 1 & 8 \\
\hline $4(19)$ & 0 & 5 & 10 & 4 & 0 & 0 & 0 & 1 & 1 & 2 & 15 \\
\hline $5(16)$ & 6 & 1 & 11 & 6 & 0 & 3 & 2 & 1 & 0 & 5 & 14 \\
\hline $6(12)$ & 5 & 1 & 9 & 2 & 0 & 2 & 1 & 1 & 1 & 1 & 12 \\
\hline $7(9)$ & 5 & 3 & 5 & 2 & 0 & 5 & 0 & 0 & 1 & 0 & 9 \\
\hline $8(11)$ & 4 & 0 & 9 & 1 & 0 & 2 & 0 & 0 & 0 & 1 & 11 \\
\hline $9(10)$ & 7 & 0 & 4 & 7 & 0 & 4 & 7 & 0 & 0 & 4 & 7 \\
\hline $10(12)$ & 10 & 0 & 12 & 1 & 0 & 10 & 0 & 0 & 0 & 0 & 12 \\
\hline Total & 60 & 16 & 99 & 35 & 5 & 44 & 15 & 8 & 6 & 22 & $123^{(2)}$ \\
\hline
\end{tabular}

Tabela 10. Número de marcadores com significância para os efeitos $\beta_{1}, \beta_{2}, \beta_{3}$ e $\beta_{4}$ em cada cromossomo para o caráter prolificidade (PRO).

\begin{tabular}{|c|c|c|c|c|c|c|c|c|c|c|c|}
\hline \multirow{2}{*}{$\begin{array}{l}\text { Cromossomo } \\
\left.\text { (marcadores }^{(1)}\right)\end{array}$} & \multicolumn{4}{|c|}{ Significância } & \multicolumn{6}{|c|}{ Efeitos simultaneamente significativos } & \multirow{2}{*}{ Total $^{(2)}$} \\
\hline & $\beta_{1}$ & $\beta_{2}$ & $\beta_{3}$ & $\beta_{4}$ & $\beta_{1} \beta_{2}$ & $\beta_{1} \beta_{3}$ & $\beta_{1} \beta_{4}$ & $\beta_{2} \beta_{3}$ & $\beta_{2} \beta_{4}$ & $\beta_{3} \beta_{4}$ & \\
\hline $1(19)$ & 5 & 3 & 14 & 4 & 2 & 5 & 1 & 2 & 1 & 4 & 15 \\
\hline $2(19)$ & 9 & 2 & 11 & 1 & 2 & 7 & 0 & 1 & 0 & 0 & 14 \\
\hline $3(13)$ & 7 & 0 & 0 & 5 & 0 & 0 & 3 & 0 & 0 & 0 & 9 \\
\hline $4(19)$ & 2 & 9 & 6 & 0 & 2 & 2 & 0 & 4 & 0 & 0 & 11 \\
\hline $5(16)$ & 8 & 2 & 9 & 2 & 2 & 3 & 1 & 2 & 0 & 2 & 14 \\
\hline $6(12)$ & 2 & 5 & 5 & 1 & 1 & 2 & 1 & 3 & 0 & 1 & 7 \\
\hline $7(9)$ & 7 & 1 & 1 & 3 & 0 & 1 & 1 & 0 & 1 & 0 & 9 \\
\hline 8 (11) & 0 & 2 & 4 & 2 & 0 & 0 & 0 & 0 & 0 & 1 & 7 \\
\hline $9(10)$ & 3 & 0 & 4 & 3 & 0 & 0 & 0 & 0 & 0 & 3 & 7 \\
\hline $10(12)$ & 4 & 3 & 7 & 2 & 1 & 2 & 0 & 2 & 0 & 1 & 8 \\
\hline Total & 47 & 27 & 61 & 23 & 10 & 22 & 7 & 14 & 2 & 12 & $101^{(2)}$ \\
\hline
\end{tabular}


Tabela 11. Número de marcadores com significância para os efeitos $\beta_{1}, \beta_{2}, \beta_{3}$ e $\beta_{4}$ em cada cromossomo para o caráter altura da espigas $(\mathrm{AE})$, altura da plantas $(\mathrm{AP})$ e posição relativa da espifa (PRE).

\begin{tabular}{|c|c|c|c|c|c|c|c|c|c|c|c|c|}
\hline \multirow{2}{*}{ Crom. ${ }^{(1)}$} & \multirow{2}{*}{ Caráter } & \multicolumn{4}{|c|}{ Significância } & \multicolumn{6}{|c|}{ Efeitos simultaneamente significativos } & \multirow{2}{*}{ Total $^{(2)}$} \\
\hline & & $\beta_{1}$ & $\beta_{2}$ & $\beta_{3}$ & $\beta_{4}$ & $\beta_{1} \beta_{2}$ & $\beta_{1} \beta_{3}$ & $\beta_{1} \beta_{4}$ & $\beta_{2} \beta_{3}$ & $\beta_{2} \beta_{4}$ & $\beta_{3} \beta_{4}$ & \\
\hline \multirow[t]{3}{*}{1 (19) } & $\mathrm{AE}$ & 2 & 3 & 7 & 3 & 0 & 1 & 1 & 2 & 0 & 1 & 11 \\
\hline & AP & 8 & 2 & 8 & 4 & 1 & 5 & 2 & 1 & 0 & 2 & 13 \\
\hline & PRE & 5 & 2 & 2 & 0 & 1 & 0 & 0 & 0 & 0 & 0 & 8 \\
\hline \multirow[t]{3}{*}{$2(19)$} & $A E$ & 1 & 4 & 11 & 2 & 0 & 0 & 0 & 2 & 0 & 2 & 14 \\
\hline & AP & 1 & 11 & 13 & 3 & 1 & 1 & 0 & 6 & 0 & 3 & 18 \\
\hline & PRE & 3 & 5 & 0 & 0 & 0 & 0 & 0 & 0 & 0 & 0 & 8 \\
\hline \multirow[t]{2}{*}{$3(13)$} & $\mathrm{AE}$ & 9 & 1 & 3 & 4 & 1 & 3 & 2 & 1 & 0 & 2 & 11 \\
\hline & $\begin{array}{l}\text { AP } \\
\text { PRE }\end{array}$ & $\begin{array}{l}9 \\
4\end{array}$ & $\begin{array}{l}3 \\
0\end{array}$ & $\begin{array}{l}6 \\
1\end{array}$ & $\begin{array}{l}5 \\
1\end{array}$ & $\begin{array}{l}2 \\
0\end{array}$ & $\begin{array}{l}3 \\
0\end{array}$ & $\begin{array}{l}3 \\
0\end{array}$ & $\begin{array}{l}1 \\
0\end{array}$ & $\begin{array}{l}2 \\
0\end{array}$ & $\begin{array}{l}1 \\
0\end{array}$ & $\begin{array}{c}13 \\
6\end{array}$ \\
\hline \multirow{3}{*}{$4(19)$} & $\mathrm{AE}$ & 0 & 0 & 6 & 6 & 0 & 0 & 0 & 0 & 0 & 2 & 10 \\
\hline & AP & 1 & 4 & 9 & 6 & 0 & 1 & 1 & 0 & 0 & 3 & 17 \\
\hline & PRE & 6 & 2 & 0 & 0 & 0 & 0 & 0 & 0 & 0 & 0 & 8 \\
\hline \multirow[t]{3}{*}{$5(16)$} & $\mathrm{AE}$ & 5 & 6 & 11 & 4 & 2 & 3 & 0 & 3 & 0 & 4 & 15 \\
\hline & AP & 10 & 5 & 15 & 6 & 2 & 10 & 4 & 4 & 2 & 6 & 16 \\
\hline & PRE & 8 & 2 & 0 & 1 & 2 & 0 & 0 & 0 & 0 & 0 & 9 \\
\hline \multirow{3}{*}{$6(12)$} & $\mathrm{AE}$ & 7 & 4 & 7 & 2 & 3 & 4 & 1 & 2 & 0 & 0 & 11 \\
\hline & AP & 8 & 1 & 8 & 3 & 0 & 4 & 2 & 1 & 0 & 2 & 12 \\
\hline & PRE & & 4 & 1 & 0 & 2 & 1 & 0 & 0 & 0 & 0 & 6 \\
\hline \multirow[t]{3}{*}{$7(9)$} & $A E$ & 6 & 3 & 6 & 0 & 1 & 6 & 0 & 1 & 0 & 0 & 8 \\
\hline & AP & 7 & 2 & 6 & 1 & 1 & 6 & 1 & 0 & 0 & 1 & 8 \\
\hline & PRE & 3 & 4 & 0 & 0 & 3 & 0 & 0 & 0 & 0 & 0 & 4 \\
\hline \multirow[t]{3}{*}{$8(11)$} & $\mathrm{AE}$ & 3 & 3 & 6 & 1 & 2 & 1 & 0 & 2 & 0 & 1 & 8 \\
\hline & $A P$ & 3 & 2 & 6 & 2 & 1 & 1 & 0 & 2 & 0 & 1 & 9 \\
\hline & PRE & 2 & 2 & 1 & 1 & 0 & 0 & 0 & 0 & 0 & 0 & 6 \\
\hline \multirow[t]{3}{*}{$9(10)$} & $\mathrm{AE}$ & 7 & 0 & 7 & 5 & 0 & 6 & 4 & 0 & 0 & 4 & 8 \\
\hline & AP & 7 & 1 & 7 & 6 & 0 & 7 & 5 & 0 & 0 & 5 & 9 \\
\hline & PRE & 0 & 1 & 3 & 0 & 0 & 0 & 0 & 0 & 0 & 0 & 4 \\
\hline \multirow{3}{*}{10 (12) } & $\mathrm{AE}$ & 5 & 4 & 10 & 1 & 0 & 5 & 1 & 3 & 0 & 1 & 11 \\
\hline & AP & 4 & 6 & 11 & 2 & 2 & 4 & 0 & 5 & 1 & 2 & 12 \\
\hline & PRE & 6 & 2 & 0 & 0 & 1 & 0 & 0 & 0 & 0 & 0 & 7 \\
\hline \multirow[t]{3}{*}{ Total } & & 45 & 28 & & 28 & 9 & & & & & & $107^{(2)}$ \\
\hline & $\mathrm{AP}$ & 58 & 37 & 89 & 38 & 10 & 42 & 18 & 20 & 5 & 26 & $127^{(2)}$ \\
\hline & PRE & 41 & 24 & 8 & 3 & 9 & 1 & 0 & 0 & 0 & 0 & $66^{(2)}$ \\
\hline
\end{tabular}


Tabela 12. Número de marcadores com significância para $\beta_{1}, \beta_{2}, \beta_{3}$ e $\beta_{4}$ em cada cromossomo para os caracteres florescimento feminino (FF), florescimento masculino (FM) e intervalo de florescimento (IF).

\begin{tabular}{|c|c|c|c|c|c|c|c|c|c|c|c|c|}
\hline \multirow{2}{*}{ Crom. ${ }^{(1)}$} & \multirow{2}{*}{ Caráter } & \multicolumn{4}{|c|}{ Significância } & \multicolumn{6}{|c|}{ Efeitos simultaneamente significativos } & \multirow{2}{*}{ Total $^{(2)}$} \\
\hline & & $\overline{\beta_{1}}$ & $\beta_{2}$ & $\beta_{3}$ & $\beta_{4}$ & $\beta_{1} \beta_{2}$ & $\beta_{1} \beta_{3}$ & $\beta_{1} \beta_{4}$ & $\beta_{2} \beta_{3}$ & $\beta_{2} \beta_{4}$ & $\beta_{3} \beta_{4}$ & \\
\hline \multirow[t]{3}{*}{$1(19)$} & $\mathrm{FF}$ & 11 & 9 & 11 & 2 & 5 & 8 & 0 & 4 & 0 & 1 & 18 \\
\hline & FM & 10 & 9 & 12 & 3 & 5 & 7 & 0 & 5 & 0 & 2 & 19 \\
\hline & IF & 1 & 1 & 0 & 0 & 0 & 0 & 0 & 0 & 0 & 0 & 2 \\
\hline \multirow{3}{*}{$2(19)$} & FF & 10 & 9 & 10 & 7 & 4 & 3 & 5 & 6 & 2 & 2 & 18 \\
\hline & FM & 7 & 6 & 3 & 4 & 3 & 0 & 3 & 1 & 2 & 1 & 12 \\
\hline & IF & 5 & 0 & 8 & 2 & 0 & 5 & 0 & 0 & 0 & 0 & 10 \\
\hline \multirow{3}{*}{$3(13)$} & FF & 7 & 5 & 2 & 2 & 2 & 1 & 1 & 0 & 1 & 0 & 11 \\
\hline & FM & 6 & 4 & 4 & 2 & 1 & 3 & 2 & 1 & 0 & 1 & 9 \\
\hline & IF & 0 & 4 & 0 & 0 & 0 & 0 & 0 & 0 & 0 & 0 & 4 \\
\hline \multirow{3}{*}{$4(19)$} & $\mathrm{FF}$ & 7 & 4 & 3 & 4 & 2 & 1 & 1 & 2 & 0 & 1 & 12 \\
\hline & FM & 3 & 7 & 5 & 5 & 1 & 0 & 2 & 3 & 2 & 0 & 13 \\
\hline & IF & 10 & 4 & 1 & 3 & 2 & 1 & 1 & 0 & 2 & 0 & 13 \\
\hline \multirow[t]{3}{*}{$5(16)$} & $\mathrm{FF}$ & 10 & 5 & 5 & 3 & 2 & 1 & 3 & 3 & 0 & 0 & 14 \\
\hline & FM & 11 & 4 & 9 & 3 & 1 & 5 & 3 & 3 & 0 & 2 & 16 \\
\hline & IF & 0 & 1 & 1 & 0 & 0 & 0 & 0 & 0 & 0 & 0 & 2 \\
\hline \multirow{3}{*}{$6(12)$} & $\mathrm{FF}$ & 5 & 3 & 7 & 0 & 2 & 1 & 0 & 0 & 0 & 0 & 12 \\
\hline & FM & 2 & 1 & 4 & 2 & 0 & 0 & 0 & 0 & 1 & 0 & 8 \\
\hline & IF & 2 & 0 & 0 & 1 & 0 & 0 & 0 & 0 & 0 & 0 & 3 \\
\hline \multirow[t]{3}{*}{$7(9)$} & FF & 5 & 3 & 4 & 3 & 2 & 0 & 1 & 1 & 0 & 2 & 9 \\
\hline & FM & 4 & 5 & 5 & 4 & 1 & 1 & 1 & 3 & 3 & 3 & 9 \\
\hline & IF & 5 & 2 & 0 & 1 & 2 & 0 & 1 & 0 & 1 & 0 & 5 \\
\hline \multirow[t]{3}{*}{$8(11)$} & FF & 6 & 2 & 2 & 1 & 2 & 2 & 1 & 1 & 1 & 0 & 6 \\
\hline & FM & 4 & 2 & 0 & 1 & 2 & 0 & 1 & 0 & 1 & 0 & 4 \\
\hline & IF & 4 & 2 & 2 & 0 & 0 & 2 & 0 & 0 & 0 & 0 & 6 \\
\hline \multirow[t]{3}{*}{$9(10)$} & FF & 7 & 2 & 1 & 2 & 1 & 1 & 2 & 0 & 0 & 0 & 8 \\
\hline & FM & 6 & 2 & 2 & 0 & 1 & 2 & 0 & 0 & 0 & 0 & 7 \\
\hline & IF & 3 & 0 & 2 & 1 & 0 & 0 & 1 & 0 & 0 & 0 & 5 \\
\hline \multirow{3}{*}{$10(12)$} & $\mathrm{FF}$ & 10 & 1 & 8 & 0 & 1 & 8 & 0 & 0 & 0 & 0 & 10 \\
\hline & FM & 9 & 1 & 9 & 0 & 0 & 8 & 0 & 0 & 0 & 0 & 11 \\
\hline & IF & 0 & 0 & 7 & 0 & 0 & 0 & 0 & 0 & 0 & 0 & 7 \\
\hline \multirow[t]{3}{*}{ Total } & $\mathrm{FF}$ & 78 & 43 & 53 & 24 & 23 & 26 & 14 & 17 & 4 & 6 & $118^{(2)}$ \\
\hline & FM & 62 & 41 & 53 & 24 & 15 & 26 & 12 & 16 & 9 & 9 & $108^{(2)}$ \\
\hline & IF & 30 & 14 & 21 & 8 & 4 & 8 & 3 & 0 & 3 & 0 & $57^{(2)}$ \\
\hline
\end{tabular}


Tabela 13. Número de marcadores com significância para os efeitos $\beta_{1}, \beta_{2}, \beta_{3}$ e $\beta_{4}$ em cada cromossomo para o caráter número de folhas acima da primeira espiga (NF).

\begin{tabular}{|c|c|c|c|c|c|c|c|c|c|c|c|}
\hline \multirow{2}{*}{$\begin{array}{l}\text { Cromossomo } \\
\left(\text { marcadores }^{(1)}\right)\end{array}$} & \multicolumn{4}{|c|}{ Significância } & \multicolumn{6}{|c|}{ Efeitos simultaneamente significativos } & \multirow{2}{*}{ Total $^{(2)}$} \\
\hline & $\beta_{1}$ & $\beta_{2}$ & $\beta_{3}$ & $\beta_{4}$ & $\beta_{1} \beta_{2}$ & $\beta_{1} \beta_{3}$ & $\beta_{1} \beta_{4}$ & $\beta_{2} \beta_{3}$ & $\beta_{2} \beta_{4}$ & $\beta_{3} \beta_{4}$ & \\
\hline $1(19)$ & 12 & 6 & 8 & 0 & 3 & 6 & 0 & 3 & 0 & 0 & 16 \\
\hline $2(19)$ & 19 & 6 & 5 & 2 & 6 & 5 & 2 & 4 & 1 & 1 & 19 \\
\hline $3(13)$ & 6 & 2 & 2 & 3 & 1 & 0 & 2 & 0 & 0 & 1 & 9 \\
\hline $4(19)$ & 6 & 13 & 1 & 0 & 3 & 0 & 0 & 0 & 0 & 0 & 17 \\
\hline $5(16)$ & 13 & 12 & 9 & 5 & 10 & 9 & 4 & 8 & 5 & 4 & 15 \\
\hline $6(12)$ & 6 & 6 & 0 & 2 & 2 & 0 & 1 & 0 & 0 & 0 & 11 \\
\hline $7(9)$ & 1 & 6 & 5 & 0 & 1 & 1 & 0 & 5 & 0 & 0 & 6 \\
\hline 8 (11) & 7 & 2 & 3 & 1 & 1 & 1 & 0 & 1 & 0 & 0 & 10 \\
\hline $9(10)$ & 1 & 5 & 0 & 3 & 0 & 0 & 0 & 0 & 2 & 0 & 7 \\
\hline $10(12)$ & 4 & 3 & 3 & 2 & 0 & 1 & 1 & 0 & 0 & 0 & 10 \\
\hline Total & 75 & 61 & 36 & 18 & 27 & 23 & 10 & 21 & 8 & 6 & $120^{(2)}$ \\
\hline
\end{tabular}

Tabela 14. Número de marcadores com significância para os efeitos $\beta_{1}, \beta_{2}, \beta_{3}$ e $\beta_{4}$ em cada cromossomo para o caráter teor de umidade nos grãos (UM).

\begin{tabular}{|c|c|c|c|c|c|c|c|c|c|c|c|}
\hline \multirow{2}{*}{$\begin{array}{l}\text { Cromossomo } \\
\left.\text { (marcadores }^{(1)}\right)\end{array}$} & \multicolumn{4}{|c|}{ Significância } & \multicolumn{6}{|c|}{ Efeitos simultaneamente significativos } & \multirow{2}{*}{ Total $^{(2)}$} \\
\hline & $\beta_{1}$ & $\beta_{2}$ & $\beta_{3}$ & $\beta_{4}$ & $\beta_{1} \beta_{2}$ & $\beta_{1} \beta_{3}$ & $\beta_{1} \beta_{4}$ & $\beta_{2} \beta_{3}$ & $\beta_{2} \beta_{4}$ & $\beta_{3} \beta_{4}$ & \\
\hline $1(19)$ & 4 & 2 & 1 & 0 & 2 & 0 & 0 & 0 & 0 & 0 & 5 \\
\hline $2(19)$ & 4 & 1 & 0 & 0 & 0 & 0 & 0 & 0 & 0 & 0 & 5 \\
\hline $3(13)$ & 3 & 0 & 0 & 1 & 0 & 0 & 1 & 0 & 0 & 0 & 3 \\
\hline $4(19)$ & 5 & 0 & 3 & 1 & 0 & 1 & 1 & 0 & 0 & 0 & 7 \\
\hline $5(16)$ & 2 & 3 & 6 & 0 & 0 & 1 & 0 & 1 & 0 & 0 & 9 \\
\hline $6(12)$ & 1 & 2 & 2 & 0 & 1 & 0 & 0 & 0 & 0 & 0 & 4 \\
\hline $7(9)$ & 2 & 0 & 0 & 0 & 0 & 0 & 0 & 0 & 0 & 0 & 2 \\
\hline 8 (11) & 1 & 0 & 0 & 2 & 0 & 0 & 0 & 0 & 0 & 0 & 3 \\
\hline $9(10)$ & 2 & 1 & 0 & 1 & 0 & 0 & 0 & 0 & 0 & 0 & 4 \\
\hline $10(12)$ & 1 & 0 & 5 & 1 & 0 & 0 & 0 & 0 & 0 & 0 & 7 \\
\hline Total & 25 & 9 & 17 & 6 & 3 & 2 & 2 & 1 & 0 & 0 & $49^{(2)}$ \\
\hline
\end{tabular}


Tabela 15. Estimativas e significâncias dos coeficientes de regressão parciais ( $\beta^{\prime}$ s) para os caracteres produção de grãos ( planta $^{-1}$ ) e prolificidade (espigas planta ${ }^{-1}$ ).

\begin{tabular}{|c|c|c|c|c|c|c|c|c|c|c|c|}
\hline \multirow{2}{*}{$\mathrm{C}^{\mathrm{a}}$} & \multirow{2}{*}{ Bin } & \multirow{2}{*}{\multicolumn{2}{|c|}{$\mathrm{cM}^{\mathrm{b}}$ Marcador }} & \multicolumn{4}{|c|}{ Produção de grãos (PG) } & \multicolumn{4}{|c|}{ Prolificidade (PRO) $^{d}$} \\
\hline & & & & $\beta_{1}{ }^{\mathrm{C}}$ & $\beta_{2}$ & $\beta_{3}$ & $\beta_{4}$ & $\beta_{1}$ & $\beta_{2}$ & $\beta_{3}$ & $\beta_{4}$ \\
\hline \multirow[t]{19}{*}{1} & 1.01 & 10,7 & umc1177 & 0,15 & $-0,20$ & $2,26^{\star \star}$ & $0,66^{*}$ & $-1,47$ & $-0,09$ & $9,12^{*}$ & 1,84 \\
\hline & 1.01 & 0,9 & bnlg1014 & 0,67 & 0,08 & $2,03^{* *}$ & 0,07 & $-2,91$ & 0,27 & $8,93^{* *}$ & 0,62 \\
\hline & 1.00 & 19,8 & umc1106 & $0,75^{*}$ & 0,14 & $2,40^{* * *}$ & 0,00 & $-0,90$ & 1,44 & $10,05^{\star * *}$ & 0,13 \\
\hline & 1.02 & 11,4 & bnlg1627 & $-0,39$ & 0,31 & $2,00^{* *}$ & $-0,16$ & $-0,70$ & $-3,31$ & 4,87 & $-0,84$ \\
\hline & 1.02 & 5,7 & bnlg1083 & $-0,47$ & $-0,19$ & $2,21^{* \star *}$ & 0,06 & $-5,17$ & $-3,55$ & $7,15^{\star}$ & 1,80 \\
\hline & 1.03 & 9,9 & umc1073 & $-0,94$ & $-0,47^{*}$ & $2,85^{\star * *}$ & $0,32^{* *}$ & $-9,69^{*}$ & $-3,25^{*}$ & $9,63^{*}$ & 1,66 \\
\hline & 1.03 & 8,7 & umc1021 & $-2,00^{*}$ & $-0,34$ & $4,24^{\star \star \star}$ & 0,35 & $-14,26^{*}$ & $-2,16$ & $21,69^{\star *}$ & 3,34 \\
\hline & 1.04 & 21,9 & bnlg2238 & $-1,58^{\star *}$ & 0,04 & $3,22^{\star * *}$ & $-0,05$ & $-15,74^{*}$ & 1,60 & $14,57^{\star *}$ & 0,58 \\
\hline & 1.05 & 13,1 & umc2025 & $-2,03^{*}$ & $0,54^{* *}$ & $4,19^{\star * * *}$ & $-0,43^{*}$ & $-15,09^{*}$ & 3,18 & $19,45^{\star * *}$ & 0,65 \\
\hline & 1.05 & 10,7 & umc1601 & $-1,64^{*}$ & $-0,13$ & $3,50^{\star * * *}$ & $-0,11$ & $-10,03$ & $-1,56$ & $20,53^{\star \star \star *}$ & $2,39^{*}$ \\
\hline & 1.06 & 5,7 & umc1508 & $-2,13^{*}$ & $-0,41$ & $2,55^{\star *}$ & 0,13 & $-11,82$ & $-4,56$ & $16,50^{\star \star \star}$ & $4,31^{*}$ \\
\hline & 1.06 & 6,8 & bnlg1598 & $-2,69^{* *}$ & $-0,72^{\star *}$ & $2,43^{* *}$ & 0,22 & $-15,44^{* *}$ & $-6,18^{*}$ & $18,44^{\star *}$ & $4,32^{*}$ \\
\hline & 1.06 & 25,6 & umc1035 & $-2,27^{\star \star}$ & $-0,55$ & $3,05^{\star \star *}$ & $0,58^{*}$ & $-9,49$ & $-4,15$ & $19,86^{* *}$ & $5,64^{*}$ \\
\hline & 1.07 & 15,9 & bnlg0615 & $-0,47$ & $-0,24$ & $2,23^{* *}$ & 0,20 & $-9,01$ 。 & $-1,32_{o o}$ & $14,20^{* *}$ & 3,44 \\
\hline & 1.10 & 24,1 & umc1431 & $-1,21^{*}$ & 0,13 & $1,29^{*}$ & 0,09 & $-3,84$ & $-1,63$ & 6,67 & 1,60 \\
\hline & 1.08 & 24,2 & phi0037 & $-0,15$ & $-0,09$ & $2,83^{* *}$ & $0,67^{* *}$ & $-2,60$ & $-3,41$ & $13,01^{*}$ & 2,08 \\
\hline & 1.11 & 11,6 & phi0120 & $-0,51^{*}$ & $0,62^{\star *}$ & $1,15^{\star}$ & $-0,68^{* *}$ & $-1,16$ & 0,19 & 3,18 & $-1,44$ \\
\hline & 1.11 & 17,6 & umc1630 & $-0,16$ & 0,19 & 0,77 & 0,07 & 3,81 & $-1,44$ & 5,15 & 2,40 \\
\hline & 1.12 & & umc1605 & $1,16^{\star *}$ & $-0,20$ & 0,37 & 0,24 & 4,19 & $-2,51^{*}$ & 3,23 & 1,85 \\
\hline \multirow[t]{19}{*}{2} & 2.01 & 4,6 & umc1165 & $-0,54$ & 0,14 & $1,39^{* * *}$ & $-0,16$ & $-7,41$ & $-0,11$ & $6,95^{\star}$ & $-3,05$ \\
\hline & 2.01 & 1,3 & bnlg1338 & $-0,67$ & $-0,02$ & $2,43^{\star * * *}$ & $-0,18$ & $-8,58$ & $-0,11$ & $9,04^{* *}$ & $-3,05$ \\
\hline & 2.01 & 1,5 & umc1227 & $-0,29$ & $-0,05$ & $1,55^{\star *}$ & $-0,06$ & $-7,27$ & $-0,58$ & $6,05^{\star}$ & $-2,51$ \\
\hline & 2.02 & 2,8 & bnlg1017 & $-0,42$ & $-0,16$ & $1,92^{* \star *}$ & 0,02 & $-7,64$ & $-0,95$ & $8,70^{*}$ & $-1,93$ \\
\hline & 2.02 & 12,9 & umc1265 & $-0,81^{*}$ & $-0,43$ & $2,04^{* * *}$ & $-0,05$ & $-13,01^{*}$ & $-0,96$ & 7,82 & $-0,94$ \\
\hline & 2.02 & 8,6 & umc1934 & $-0,69^{*}$ & $-0,37^{*}$ & $2,72^{\star \star}$ & 0,27 & $-11,79^{* * *}$ & $-2,69$ & $13,24^{*}$ & 0,79 \\
\hline & 2.02 & 4,0 & bnlg0125 & $-0,24$ & 0,00 & $2,24^{* *}$ & 0,26 & $-14,27^{* *}$ & 0,93 & $10,40^{*}$ & $-0,45$ \\
\hline & 2.03 & 0,9 & umc1845 & $-1,05$ & 0,12 & $3,66^{\star \star *}$ & $-0,77^{* *}$ & $-19,38^{* *}$ & 2,63 & $13,52^{*}$ & $-3,78$ \\
\hline & 2.03 & 2,5 & umc1776 & $-1,14$ & 0,38 & $3,39^{\star * *}$ & $-0,48$ & $-20,56^{* *}$ & 2,70 & $12,11^{\star *}$ & $-2,53$ \\
\hline & 2.03 & 7,1 & bnlg2248 & $-1,38^{*}$ & $-0,04$ & $4,06^{\star \star \star \star \star}$ & $-0,16$ & $-20,90^{\star * *}$ & 2,68 & $15,63^{*}$ & $-2,14$ \\
\hline & 2.03 & 32,2 & bnlg0381 & $-0,76^{*}$ & 0,27 & $3,02^{\star * *}$ & $-0,07$ & $-21,67^{\star *}$ & $4,13^{*}$ & $13,86^{*}$ & $-2,82$ \\
\hline & 2.04 & 10,1 & bnlg0166 & $-1,75^{\star *}$ & 0,06 & $2,25^{\star *}$ & $-0,27$ & $-13,07^{* *}$ & $-0,10$ & $11,08^{* *}$ & $-3,37$ \\
\hline & 2.05 & 19,5 & dupssr21 & $-1,85^{\star \star *}$ & $-0,46$ & $1,96^{* *}$ & $0,56^{*}$ & $-10,28^{*}$ & $-5,07^{* \star * *}$ & 8,16 & 0,09 \\
\hline & 2.06 & 78,3 & bnlg1396 & $-0,30$ & $-0,21$ & 1,11 & 0,21 & 3,67 & $-1,44$ & 3,81 & $-0,73$ \\
\hline & 2.07 & 6,3 & umc1560 & $-0,86$ & $-0,15$ & 0,78 & $-0,59^{*}$ & $-2,46$ & $-0,88$ & 1,86 & $-1,23$ \\
\hline & 2.08 & 6,5 & umc1464 & $-0,95$ & $-0,15$ & $1,51^{\star *}$ & 0,24 & $-2,06$ & $-0,68$ & 2,34 & 2,36 \\
\hline & 2.08 & 6,9 & umc1633 & $-0,92$ & 0,02 & $0,88^{*}$ & 0,28 & $-1,48$ & 1,44 & 0,39 & 2,35 \\
\hline & 2.09 & 4,9 & umc1230 & $-1,28$ & $-0,04$ & $0,74^{*}$ & 0,50 & 1,24 & 2,21 & 1,39 & $3,44^{\text {** }}$ \\
\hline & 2.09 & & bnlg1520 & $-1,01$ & 0,04 & 0,51 & 0,19 & 3,49 & 2,65 & 1,19 & 1,17 \\
\hline \multirow[t]{13}{*}{3} & 3.01 & 17,4 & umc1394 & $-0,20$ & $-0,34$ & 0,04 & $-0,19$ & 0,52 & $-2,21$ & 3,11 & $-0,78$ \\
\hline & 3.03 & 27,7 & bnlg1144 & $-0,76^{*}$ & 0,32 & $1,89^{\star *}$ & 0,08 & $-7,94^{*}$ & 2,50 & 4,58 & 0,21 \\
\hline & 3.04 & 7,8 & bnlg1452 & $-0,03$ & 0,47 & $2,15^{\star *}$ & $-0,56^{*}$ & $-3,98$ & 1,79 & 1,55 & $-3,20^{* *}$ \\
\hline & 3.04 & 12,1 & bnlg602 & $-0,47$ & 0,21 & $2,28^{\star *}$ & $-0,17$ & $-7,86$ & $-1,51$ & $-1,35$ & $-2,08$ \\
\hline & 3.05 & 1,8 & bnlg0420 & $-0,76$ & 0,12 & $1,07^{\star *}$ & $-0,11$ & $-5,62$ & 0,30 & $-2,83$ & 0,18 \\
\hline & 3.05 & 34,1 & $\mathrm{mmc} 0022$ & $-0,65$ & 0,09 & $1,49^{\star * \star * *}$ & $-0,02$ & $-6,33$ & 0,88 & $-1,93$ & 0,34 \\
\hline & 3.06 & 28,6 & bnlg1798 & $-2,13^{\star *}$ & $-0,32$ & 0,89 & $0,84^{\star * *}$ & $-10,50$ & $-2,20$ & $-1,72$ & $4,47^{*}$ \\
\hline & 3.07 & 3,3 & umc1690 & $-0,87$ & 0,01 & 0,480 & $-0,64^{*}$ & $-6,27^{*}$ & 3,87 。 & $-0,05$ 。 & $-2,02$ \\
\hline & 3.07 & 16,0 & umc1659 & $-1,50$ & $-0,03$ & 0,27 & $-0,27$ & $-14,34^{\star *}$ & 1,88 & 0,38 & 0,77 \\
\hline & 3.08 & 14,1 & umc1320 & $-1,90^{*}$ & $-0,12$ & $1,75^{\star}$ & 0,14 & $-21,62^{\star *}$ & $-0,05$ & 8,03 & 1,76 \\
\hline & 3.09 & 2,9 & bnlg1536 & $-1,78^{*}$ & $-0,27$ & 0,95 & 0,23 & $-22,40^{*}$ 。 & $-0,59$ & 4,81 & $3,81^{*}$ \\
\hline & 3.09 & 26,7 & bnlg1754 & $-1,66^{*}$ & $-0,17$ & 0,76 & $-0,11$ & $-21,32^{* *}$ & 1,83 & 1,68 & $2,60^{*}$ \\
\hline & 3.10 & & bnlg1098 & $-1,38^{*}$ & $-0,68^{\star \star \star}$ & 0,28 & $-0,08$ & $-11,46^{*}$ & $-1,10$ & 7,18 & $3,91^{* *}$ \\
\hline
\end{tabular}


Tabela 15. Estimativas e significâncias dos coeficientes de regressão parciais ( $\beta^{\prime}$ s) para os caracteres produção de grãos ( planta $^{-1}$ ) e prolificidade (espigas planta ${ }^{-1}$ ).

\begin{tabular}{|c|c|c|c|c|c|c|c|c|c|c|c|}
\hline \multirow{2}{*}{$\mathrm{C}^{\mathrm{a}}$} & \multirow{2}{*}{ Bin } & \multirow{2}{*}{$\mathrm{cM}^{\mathrm{b}}$} & \multirow{2}{*}{ Marcador } & \multicolumn{4}{|c|}{ Produção de grãos (PG) } & \multicolumn{4}{|c|}{ 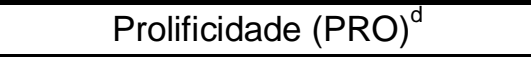 } \\
\hline & & & & $\beta_{1}{ }^{\mathrm{C}}$ & $\beta_{2}$ & $\beta_{3}$ & $\beta_{4}$ & $\beta_{1}$ & $\beta_{2}$ & $\beta_{3}$ & $\beta_{4}$ \\
\hline \multirow[t]{19}{*}{4} & 4.01 & 55,7 & umc1276 & $0,42_{o \circ}$ & $-0,390$ & $2,13^{*}$ & $0,27^{* *}$ & $-0,22$ & $-3,61^{*}$ & 5,15 & $-0,26$ \\
\hline & 4.04 & 3,4 & umc1652 & $-0,16$ & 0,09 & $1,25^{*}$ & 0,15 & 1,32 & $-3,68^{*}$ & $6,70^{*}$ & 1,20 \\
\hline & 4.05 & 0,1 & phi0026 & 0,06 & 0,23 & $0,92^{*}$ & $-0,27$ & 2,72 & $-2,15$ & $4,90^{*}$ & $-0,53$ \\
\hline & 4.05 & 1,7 & umc1088 & $-0,10$ & 0,07 & $1,36^{\star *}$ & 0,02 & 0,69 & $-3,27^{* *}$ & $7,67^{*}$ & 0,40 \\
\hline & 4.06 & 35,6 & bnlg0252 & $-0,09$ & 0,20 & $1,08^{* *}$ & $-0,05$ & 1,25 & $-1,55$ & $4,98^{*}$ & 0,29 \\
\hline & 4.07 & 5,1 & bnlg2291 & 0,42 & 0,28 & $1,37^{\star * *}$ & $-0,27$ & $7,39^{*}$ & $3,92^{* *}$ & $8,48^{* *}$ & 1,57 \\
\hline & 4.07 & 18,0 & dupssr34 & 0,17 & 0,29 & $0,74^{\star \star}$ & $-0,38$ & $6,06^{*}$ & $4,44^{*}$ & $6,85^{\star *}$ & 0,02 \\
\hline & 4.08 & 2,0 & bnlg2244 & 0,63 & 0,40 & $1,50^{*}$ & $-0,88^{*}$ & 9,07 & $5,28^{\star *}$ & 8,21 & $-2,94$ \\
\hline & 4.08 & 4,7 & bnlg2162 & 0,59 & 0,49 & 0,52 & $-1,19^{* *}$ & 11,54 & $6,79^{* * *}$ & 4,89 & $-3,82$ \\
\hline & 4.08 & 4,6 & umc1086 & 0,34 & 0,35 & $2,04^{* *}$ & $-0,11$ & 6,07 。 & $5,56^{* * *}$ & 9,18 & 0,38 \\
\hline & 4.08 & 11,5 & umc1051 & 0,07 & $0,51^{*}$ & $1,43^{*}$ & $-0,02$ & 5,23 。 & $5,73^{\star \star *}$ & 6,93 & 1,18 \\
\hline & 4.09 & 15,6 & umc1989 & $-0,33$ & $-0,15$ & 0,12 & 0,14 & $1,00_{0}$ & 1,16 & 1,32 & 0,02 \\
\hline & 4.09 & 0,6 & phi314704 & $-0,86$ & $-0,40$ & $-0,75$ & $-0,40$ & $-3,74_{\circ o}$ & 1,75 。 & $-0,11$ & $-0,63$ \\
\hline & 4.11 & 0,2 & bnlg0589 & $-0,59$ & $-0,46^{*}$ & $-0,57$ & $-0,33$ & $-7,27_{\text {o。 }}$ & $-0,72_{\circ}$ & 0,39 & $-0,21$ \\
\hline & 4.10 & 0,2 & umc1503 & $-1,03$ & $-0,61^{*}$ & $-0,41$ & $-0,23$ & $-5,27_{\circ \circ}$ & 0,27 。 & 1,36 & 0,28 \\
\hline & 4.10 & 5,9 & umc1532 & $-0,90$ & $-0,55^{\star}$ & $-0,39$ & $-0,14$ & $-5,46_{\circ \circ}$ & $-0,11$ 。 & 2,16 & 0,94 \\
\hline & 4.10 & 6,3 & umc1109 & $-0,56$ & $-0,56^{*}$ & $-1,06$ & $-0,81^{* *}$ & $-1,05$ & 3,29 & $-1,45$ & $-1,95$ \\
\hline & 4.11 & 6,2 & bnlg1337 & $-0,46$ & $-0,59$ & $-0,94$ & $-0,43$ & $-0,36$ & $-0,04$ & $-2,46$ & $-0,78$ \\
\hline & 4.11 & & umc1197 & $-0,24$ & $-0,27$ & $-0,57$ & $-0,64$ & $-1,07$ & 2,08 & 0,57 & $-0,50$ \\
\hline \multirow[t]{16}{*}{5} & 5.00 & 40,7 & bnlg1006 & $-1,21$ & 0,04 & $1,95^{\star *}$ & $-0,31$ & $-11,15^{*}$ & $2,89^{*}$ & $12,99^{* *}$ & $-2,42$ \\
\hline & 5.02 & 8,3 & umc1587 & $-0,14$ & $-0,30$ & $2,24^{\star *}$ & $-0,19$ & $-5,00^{*}$ & $-0,71$ & $10,29^{* *}$ & $-2,36^{*}$ \\
\hline & $5.03-04$ & 5,3 & phi0113 & $-0,07$ & $-0,25$ & $2,29^{\star \star *}$ & 0,11 & $-5,28$ & $-2,35$ & $10,15^{\star *}$ & $-1,71$ \\
\hline & 5.03 & 16,1 & bnlg1879 & $-0,64$ & $-0,58^{*}$ & $2,57^{* * *}$ & $-0,07$ & $-10,01^{*}$ & $-3,35^{*}$ & $12,34^{* *}$ & $-1,21$ \\
\hline & 5.03 & 14,1 & umc1056 & 0,13 & 0,46 & $2,63^{* *}$ & $-0,54^{* *}$ & $-9,22$ & 1,15 & $8,23^{*}$ & $-3,06^{*}$ \\
\hline & 5.03 & 9,7 & bnlg1902 & 1,19 & 0,53 & $3,27^{* *}$ & $-0,72^{\star *}$ & $-3,39$ 。 & 2,04 & $12,61^{* *}$ & 0,03 \\
\hline & 5.04 & 17,7 & dupssr10 & 0,89 & 0,58 & $4,10^{\star \star *}$ & $-0,87^{\star \star \star}$ & $-4,04 。$ & 0,80 & $14,94^{\star *}$ & $-1,19$ \\
\hline & 5.04 & 3,8 & umc1221 & $1,78^{*}$ & $-0,06$ & $3,11^{* *}$ & $-0,72^{* *}$ & 9,74 & $-0,50$ & $8,74^{*}$ & $-0,72$ \\
\hline & 5.05 & 23,5 & $\mathrm{mmc} 0081$ & 1,47 & 0,20 & $2,81^{* *}$ & $-1,04^{* *}$ & 8,07 & 0,73 & $6,78^{*}$ & $-3,13$ \\
\hline & 5.06 & 2,1 & umc1019 & $2,45^{*}$ & 0,22 & 0,76 & $-0,42^{*}$ & $16,43^{* *}$ & 1,65 & $-1,88$ & $-1,07$ \\
\hline & 5.06 & 2,3 & $\mathrm{mmc} 0481$ & $2,06^{*}$ & $-0,11$ & $1,41^{*}$ & $-0,17$ & $14,83^{*}$ & $-0,28$ & 0,41 & 0,06 \\
\hline & $5.05-06$ & 1,6 & bnlg278 & $2,08^{*}$ 。 & $-0,22$ & $0,97^{*}$ & $-0,03$ & $14,10^{*}$ & $-0,81$ & $-0,88$ & 1,04 \\
\hline & 5.06 & 0,1 & umc1680 & $2,25^{*}$ 。 & $-0,23$ & 1,08 & $-0,01$ & $14,85^{*}$ & $-1,14$ & 0,71 & 0,84 \\
\hline & 5.06 & 21,9 & umc1524 & $2,13^{*}$ 。 & $-0,26$ & 1,26 & $-0,02$ & $14,50^{*}$ & $-1,29$ & 1,43 & 0,84 \\
\hline & 5.07 & 32,3 & phi0128 & 1,46 。 & $-0,40$ & 0,97 & 0,08 & 7,61 & $-2,91$ & $-0,40$ & 0,41 \\
\hline & 5.09 & & umc1153 & $-0,33$ & 0,42 & $-0,40$ & $-0,25$ & $-1,19$ & 0,67 & 1,78 & 0,68 \\
\hline \multirow[t]{12}{*}{6} & 6.00 & 34,3 & phi0126 & $-0,72$ & $0,33^{*}$ & $0,99^{*}$ & $-0,92^{* *}$ & $-6,62$ & 2,97 & 2,82 & $-2,48$ \\
\hline & 6.02 & 14,3 & bnlg1371 & $-1,23^{*}$ & 0,20 & $1,52^{\star \star *}$ & $-0,39$ & $-5,84^{*}$ & 1,59 & $7,71^{*}$ & $-3,09^{* *}$ \\
\hline & 6.01 & 9,9 & phi0077 & $-1,21^{*}$ & 0,13 & $3,42^{\star * * * *}$ & $-0,11$ & $-5,27$ & $-1,50$ & $14,85^{\star \star *}$ & $-2,09$ \\
\hline & 6.02 & 0,8 & umc1006 & $-0,73$ & 0,34 & $1,30^{\star *}$ & $-0,44$ & $-3,58$ & $3,56^{*}$ & $9,06^{*}$ & $-3,07$ \\
\hline & 6.02 & 13,1 & umc1257 & $-0,38$ & 0,31 & $1,43^{\star *}$ & $-0,49$ & $-0,25$ & $3,70^{*}$ & $7,83^{*}$ & $-3,42$ \\
\hline & 6.03 & 13,9 & umc1887 & $-0,53$ & 0,07 & $1,99^{\star * * *}$ & 0,08 & $-4,31$ & 1,46 & 6,16 & 0,14 \\
\hline & 6.04 & 18,9 & umc1614 & $-0,80$ & $-0,17$ & $2,03^{* * *}$ & $-0,01$ & $-11,98$ & 1,19 & 5,98 & 0,84 \\
\hline & 6.05 & 22,4 & $\mathrm{nc} 0013$ & $-0,23$ & 0,14 & $1,04^{*}$ & $-0,25$ & $-3,36$ & 2,91 & 7,03 & $-0,34$ \\
\hline & 6.06 & 21,2 & umc1520 & $-0,88$ & 0,24 & $0,76^{*}$ & $-0,02$ & $-8,37$ & 3,02 & 4,06 & $-0,51$ \\
\hline & 6.07 & 11,5 & bnlg1759 & $-1,93^{\star *}$ & 0,16 & 1,08 & $-0,41^{*}$ & $-13,38^{*}$ & $4,19^{*}$ & $10,36^{*}$ & $-1,97$ \\
\hline & 6.07 & 2,6 & umc1653 & $-1,41^{*}$ & 0,03 & 0,71 & 0,23 & $-8,87$ & $4,69^{* *}$ & 3,98 & 1,17 \\
\hline & 6.08 & & umc1127 & $-1,41^{\star *}$ & $-0,13$ & 0,62 & 0,32 & $-8,15$ & $3,37^{*}$ & 5,19 & 1,71 \\
\hline
\end{tabular}


Tabela 15. Estimativas e significâncias dos coeficientes de regressão parciais ( $\beta^{\prime}$ s) para os caracteres produção de grãos (g planta ${ }^{-1}$ ) e prolificidade (espigas planta ${ }^{-1}$ ).

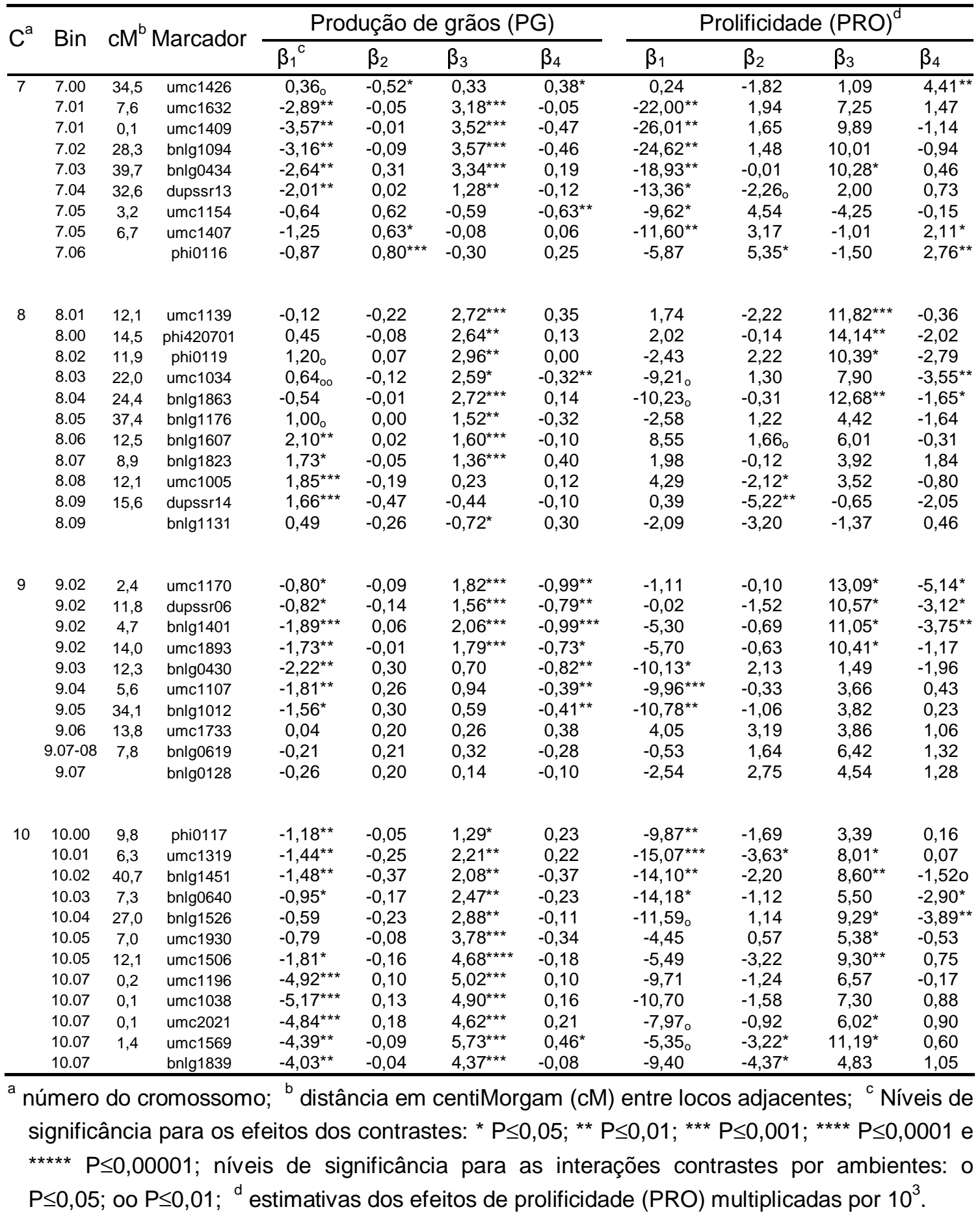


Tabela 16. Estimativas e significâncias dos coeficientes de regressão parciais ( $\beta^{\prime}$ s) para os caracteres altura da espiga ( $\mathrm{cm}$ planta $\left.{ }^{-1}\right)$ e altura da planta ( $\mathrm{cm}$ planta $\left.{ }^{-1}\right)$.

\begin{tabular}{|c|c|c|c|c|c|c|c|c|c|c|c|}
\hline \multirow{2}{*}{$\mathrm{C}^{\mathrm{a}}$} & \multirow{2}{*}{ Bin } & \multirow{2}{*}{$\mathrm{cM}^{\mathrm{b}}$} & \multirow{2}{*}{ Marcador } & \multicolumn{4}{|c|}{ Altura da espiga (AE) } & \multicolumn{4}{|c|}{ Altura da planta (AP) } \\
\hline & & & & $\beta_{1}{ }^{c}$ & $\beta_{2}$ & $\beta_{3}$ & $\beta_{4}$ & $\beta_{1}$ & $\beta_{2}$ & $\beta_{3}$ & $\beta_{4}$ \\
\hline \multirow[t]{19}{*}{1} & 1.01 & 10,7 & umc1177 & $-0,22$ & $-0,18$ & 0,30 & $0,18^{* *}$ & 0,29 & $-0,14$ & 0,41 & $0,35^{\star \star \star}$ \\
\hline & 1.01 & 0,9 & bnlg1014 & $0,05_{\circ \circ}$ & $-0,09$ & 0,29 & 0,07 & 0,76 。 & 0,00 & 0,28 & 0,09 \\
\hline & 1.00 & 19,8 & umc1106 & $-0,09_{000}$ & $-0,05$ & 0,36 & $0,08^{*}$ & $0,35_{\circ o}$ & $-0,04$ & 0,44 & 0,13 \\
\hline & 1.02 & 11,4 & bnlg1627 & $0,24_{\text {oо }}$ & $0,10^{*}$ & 0,32 & 0,04 & $1,20^{*}$ 。 & $0,22^{*}$ & 0,29 & 0,08 \\
\hline & 1.02 & 5,7 & bnlg1083 & $-0,01$ & $-0,10$ & 0,14 & 0,10 & $1,34^{* *}$ & $-0,09$ & 0,17 & 0,15 \\
\hline & 1.03 & 9,9 & umc1073 & $-0,04$ & $-0,29$ & $0,33^{*}$ & 0,10 & $1,23^{* * *}$ & $-0,28$ & $0,75^{\star *}$ & 0,13 \\
\hline & 1.03 & 8,7 & umc1021 & $-0,04$ & $-0,28_{0}$ 。 & $0,46^{*}$ & 0,02 & $0,88^{*}$ & $-0,50$ 。 & $1,08^{*}$ & $-0,07$ \\
\hline & 1.04 & 21,9 & bnlg2238 & 0,46 。 & $-0,31^{* *}$ & $0,50^{*}$ & $-0,12$ & 1,01 & $-0,32^{*}$ & $0,91^{* * *}$ & $-0,19$ \\
\hline & 1.05 & 13,1 & umc2025 & 0,25 & 0,18 & $0,71^{* * *}$ & $-0,10$ & $-0,26$ & 0,13 & $1,02^{* * *}$ & $-0,11$ \\
\hline & 1.05 & 10,7 & umc1601 & 0,24 & $-0,24^{*}$ & $0,53^{*}$ & $-0,05$ & 0,02 & $-0,28$ & $0,93^{* *}$ & $-0,12$ \\
\hline & 1.06 & 5,7 & umc1508 & 0,02 & $-0,08$ & 0,58 & 0,07 & $-0,48$ & $-0,18$ & 0,67 & 0,13 \\
\hline & 1.06 & 6,8 & bnlg1598 & $-0,19$ & $-0,02$ & 0,74 & 0,07 & $-0,96^{*}$ & $-0,12$ & $0,92^{*}$ & 0,17 \\
\hline & 1.06 & 25,6 & umc1035 & 0,03 & 0,05 & 0,73 & 0,16 & $-0,70^{*}$ & $-0,10$ & $0,99^{*}$ & $0,33^{*}$ \\
\hline & 1.07 & 15,9 & bnlg0615 & $-0,24_{\circ \circ o}$ & $-0,04$ & $0,54^{*}$ & 0,09 & $-0,90_{\text {०००० }}$ & $-0,14$ & 0,45 & $0,24^{*}$ \\
\hline & 1.10 & 24,1 & umc1431 & $-0,52^{*}$ & 0,02 & 0,12 & 0,12 & $-1,27^{\star \star}$ & 0,02 & 0,27 & 0,16 \\
\hline & 1.08 & 24,2 & phi0037 & $-0,78^{*}$ & $-0,04$ & $0,67^{* *}$ & $0,26^{\star *}$ & $-1,52^{\star *}$ & 0,06 & $0,78^{* *}$ & $0,34^{\star *}$ \\
\hline & 1.11 & 11,6 & phi0120 & 0,26 & 0,15 & 0,24 & $-0,04$ & 0,19 & 0,23 & 0,21 & $-0,02$ \\
\hline & 1.11 & 17,6 & umc1630 & 0,39 & 0,07 & 0,25 & $-0,04$ & 0,35 & 0,05 & 0,29 & $-0,05$ \\
\hline & 1.12 & --- & umc1605 & 0,11 & 0,05 & 0,14 & 0,07 & $-0,23$ & $-0,06$ & 0,11 & 0,06 \\
\hline \multirow[t]{19}{*}{2} & 2.01 & 4,6 & umc1165 & $-0,04$ & 0,03 & 0,12 & 0,10 & 0,22 & $0,41^{*}$ & 0,11 & 0,05 \\
\hline & 2.01 & 1,3 & bnlg1338 & $-0,34$ & $-0,07^{*}$ & $0,36^{*}$ & 0,04 & $-0,08$ & $0,23^{*}$ & $0,39^{*}$ & $-0,03$ \\
\hline & 2.01 & 1,5 & umc1227 & $-0,30$ & 0,00 & 0,13 & 0,06 & $-0,16$ & $0,30^{* *}$ & 0,23 & $-0,02$ \\
\hline & 2.02 & 2,8 & bnlg1017 & $-0,28$ & 0,02 & 0,19 & 0,06 & $-0,10$ & $0,33^{* * *}$ & 0,30 & $-0,02$ \\
\hline & 2.02 & 12,9 & umc1265 & $-0,35$ & $0,13^{* \star *}$ & 0,26 & 0,00 & $-0,44$ & $0,46^{\star * *}$ & 0,41 & $-0,09$ \\
\hline & 2.02 & 8,6 & umc1934 & 0,11 & 0,11 & 0,28 & 0,24 & 0,48 & $0,32^{*}$ & $0,61^{*}$ & 0,31 \\
\hline & 2.02 & 4,0 & bnlg0125 & 0,25 & 0,23 & $0,46^{* *}$ & 0,14 & 0,60 & $0,33^{* *}$ & $0,89^{\star \star \star \star}$ & 0,13 \\
\hline & 2.03 & 0,9 & umc1845 & 0,06 & 0,18 & $0,81^{* \star *}$ & $-0,06$ & 0,43 & 0,17 & $1,40^{\star \star \star *}$ & $-0,12$ \\
\hline & 2.03 & 2,5 & umc1776 & 0,20 & 0,17 & $0,61^{* * *}$ & 0,05 & $0,63^{* *}$ & $0,28^{*}$ & $0,97^{* * *}$ & 0,10 \\
\hline & 2.03 & 7,1 & bnlg2248 & $-0,09$ & 0,10 & $0,62^{*}$ & 0,13 & 0,20 & 0,16 & $1,14^{\star \star \star}$ & 0,19 \\
\hline & 2.03 & 32,2 & bnlg0381 & 0,45 & 0,07 & $0,85^{\star *}$ & 0,10 & 0,80 & 0,10 & $1,41^{* *}$ & $0,15^{\star}$ \\
\hline & 2.04 & 10,1 & bnlg0166 & $-0,14$ & 0,21 & $0,94^{* *}$ & $0,18^{* *}$ & $-0,16$ & 0,15 & $1,39^{* *}$ & $0,25^{* * *}$ \\
\hline & 2.05 & 19,5 & dupssr21 & $-0,47$ & 0,02 & $0,93^{* *}$ & $0,24^{*}$ & $-0,49$ & $-0,12$ & $1,34^{\star *}$ & $0,30^{*}$ \\
\hline & 2.06 & 78,3 & bnlg1396 & $-0,36$ & $-0,01$ & $0,71^{* * *}$ & 0,05 & $-0,10$ & $-0,12$ & $1,15^{\star *}$ & 0,14 \\
\hline & 2.07 & 6,3 & umc1560 & $0,54^{*}$ & $-0,03$ & 0,21 & 0,13 & 0,40 & 0,16 & 0,38 & 0,07 \\
\hline & 2.08 & 6,5 & umc1464 & $-0,09$ & $-0,08$ & $0,61^{*}$ & 0,13 & $-0,29$ 。 & 0,16 & $1,06^{*}$ & 0,17 \\
\hline & 2.08 & 6,9 & umc1633 & 0,18 & $0,25^{*}$ & $0,44^{*}$ & 0,14 & $-0,03$ & $0,56^{* *}$ & $0,78^{*}$ & 0,20 \\
\hline & 2.09 & 4,9 & umc1230 & $-0,01$ & 0,21 & 0,22 & 0,12 & $-0,31$ & $0,44^{* *}$ & $0,51^{*}$ & 0,21 \\
\hline & 2.09 & --- & bnlg1520 & 0,03 & $0,41^{* *}$ & 0,21 & $-0,02$ & $-0,25$ & $0,68^{\star * *}$ & 0,45 & 0,04 \\
\hline \multirow[t]{13}{*}{3} & 3.01 & 17,4 & umc1394 & $-0,50^{*}$ & $-0,02$ & $-0,16$ & 0,02 & $-0,43^{*}$ & $-0,03$ 。 & $-0,27$ & 0,00 \\
\hline & 3.03 & 27,7 & bnlg1144 & $-0,40^{*}$ & $0,26^{*}$ & $0,77^{*}$ & $-0,05$ & $-0,14$ & 0,28 & $1,00^{* *}$ & $-0,08$ \\
\hline & 3.04 & 7,8 & bnlg1452 & 0,33 & $-0,02$ & 0,40 & $-0,09$ & $0,54^{*}$ & $-0,06$ & $0,91^{* *}$ & $-0,15$ \\
\hline & 3.04 & 12,1 & bnlg602 & $-0,13$ & $-0,01$ & 0,42 & 0,01 & 0,05 & $-0,12^{* *}$ & $1,01^{\text {** }}$ & $-0,01$ \\
\hline & 3.05 & 1,8 & bnlg0420 & $0,59^{\star}$ & 0,21 & 0,16 & $-0,05$ & $0,76^{*}$ & 0,10 & $0,72^{\star *}$ & $-0,11$ \\
\hline & 3.05 & 34,1 & $\mathrm{mmc0022}$ & $0,59^{* *}$ & 0,10 & 0,35 & $-0,05$ & $0,66^{\star *}$ & $-0,07$ & $0,94^{\star * *}$ & $-0,05$ \\
\hline & 3.06 & 28,6 & bnlg1798 & $0,31^{*}$ & $-0,10$ & $0,29^{* *}$ & $0,14^{\star}$ & 0,19 & $-0,20$ & $0,42^{\star *}$ & $0,15^{*}$ \\
\hline & 3.07 & 3,3 & umc1690 & $-0,21$ & $-0,08$ & 0,31 & $-0,16^{*}$ & $-0,54^{*}$ & $-0,15^{*}$ & 0,13 & $-0,26^{*}$ \\
\hline & 3.07 & 16,0 & umc1659 & $-0,40^{\star *}$ & $-0,19$ & $0,32^{*}$ & $-0,13^{* *}$ & $-0,64^{*}$ & $-0,23^{*}$ & 0,02 & $-0,21^{\star *}$ \\
\hline & 3.08 & 14,1 & umc1320 & $-1,19^{\star *}$ & $-0,04$ & 0,35 & 0,01 & $-1,24^{*}$ & 0,00 & 0,30 & 0,07 \\
\hline & 3.09 & 2,9 & bnlg1536 & $-1,22^{* *}$ 。 & 0,01 & $-0,08$ & $-0,01$ & $-1,51^{*}$ оо & $-0,04$ & $-0,14$ & $-0,06$ \\
\hline & 3.09 & 26,7 & bnlg1754 & $-0,99^{*}$ & 0,13 & 0,01 & $-0,06$ & $-1,27^{*}$ 。 & 0,09 & $-0,04$ & $-0,20^{*}$ \\
\hline & 3.10 & -- & bnlg1098 & $-0,62$ & 0,10 & $-0,17$ & $-0,21^{\text {** }}$ & $-0,67$ & 0,12 & 0,07 & $-0,22^{* *}$ \\
\hline
\end{tabular}


Tabela 16. Estimativas e significâncias dos coeficientes de regressão parciais ( $\beta^{\prime}$ s) para os caracteres altura da espiga ( $\mathrm{cm}$ planta $\left.{ }^{-1}\right)$ e altura da planta ( $\mathrm{cm}$ planta $\left.{ }^{-1}\right)$.

\begin{tabular}{|c|c|c|c|c|c|c|c|c|c|c|c|}
\hline \multirow{2}{*}{$\mathrm{C}^{\mathrm{a}}$} & \multirow{2}{*}{ Bin } & \multirow{2}{*}{$\mathrm{cM}^{\mathrm{b}}$} & \multirow{2}{*}{ Marcador } & \multicolumn{4}{|c|}{ Altura da espiga (AE) } & \multicolumn{4}{|c|}{ Altura da planta (AP) } \\
\hline & & & & $\beta_{1}{ }^{\mathrm{c}}$ & $\beta_{2}$ & $\beta_{3}$ & $\beta_{4}$ & $\beta_{1}$ & $\beta_{2}$ & $\beta_{3}$ & $\beta_{4}$ \\
\hline \multirow[t]{19}{*}{4} & 4.01 & 55,7 & umc1276 & 0,38 & 0,03 & $0,83^{* \star}$ & 0,04 & 0,50 & $0,00_{\text {oо }}$ & $1,14^{* * *}$ & 0,03 \\
\hline & 4.04 & 3,4 & umc1652 & 0,12 & $-0,01$ & $0,74^{* *}$ & $-0,05$ & $-0,33$ & 0,01 & $0,91^{* *}$ & $-0,06$ \\
\hline & 4.05 & 0,1 & phi0026 & 0,13 & $-0,03$ & $0,72^{* * *}$ & $-0,08^{*}$ & $-0,32$ & $-0,01$ & $1,01^{* *}$ & $-0,14^{*}$ \\
\hline & 4.05 & 1,7 & umc1088 & 0,24 & $-0,08$ & $0,76^{\star *}$ & 0,00 & $-0,43$ & $-0,09$ & $1,08^{* *}$ & $-0,03$ \\
\hline & 4.06 & 35,6 & bnlg0252 & $-0,01$ & $-0,06$ & $0,58^{* *}$ & $-0,09^{\star *}$ & $-0,56$ & $-0,08$ & $0,89^{* *}$ & $-0,13$ \\
\hline & 4.07 & 5,1 & bnlg2291 & 0,24 & 0,05 & 0,60 & $-0,13$ & 0,27 & 0,04 & $0,80^{* *}$ & $-0,21^{*}$ \\
\hline & 4.07 & 18,0 & dupssr34 & 0,23 & 0,13 & 0,33 & $-0,19^{*}$ & $0,56^{*}$ & 0,04 & $0,51^{*}$ & $-0,34^{*}$ \\
\hline & 4.08 & 2,0 & bnlg2244 & 0,21 & 0,18 & 0,30 & $-0,19$ 。 & 0,60 & $0,20_{\circ}$ & 0,46 & $-0,43_{0}$ \\
\hline & 4.08 & 4,7 & bnlg2162 & 0,09 & 0,09 & 0,12 & $-0,24_{\circ}$ & 0,32 & 0,03 & 0,26 & $-0,48^{*}$ \\
\hline & 4.08 & 4,6 & umc1086 & $-0,16$ & $-0,01$ & 0,37 & 0,03 & 0,05 & $-0,11$ & $0,77^{\star *}$ & $-0,17$ \\
\hline & 4.08 & 11,5 & umc1051 & $-0,04$ & $-0,02$ & 0,20 & 0,01 & 0,08 & 0,00 & $0,48^{*}$ & $-0,17$ \\
\hline & 4.09 & 15,6 & umc1989 & 0,32 & 0,02 & 0,03 & $-0,05$ & 0,69 & $-0,10$ & 0,35 & $-0,13$ \\
\hline & 4.09 & 0,6 & phi314704 & 0,02 & $-0,12$ & $-0,27^{*}$ & $-0,13$ & 0,31 & $-0,34^{*}$ & $-0,17$ & $-0,22$ \\
\hline & 4.11 & 0,2 & bnlg0589 & 0,21 & $-0,07$ & $-0,14$ & $-0,06$ & 0,45 & $-0,32^{*}$ & $-0,06$ & $-0,09$ \\
\hline & 4.10 & 0,2 & umc1503 & $-0,06$ & $-0,13$ & $-0,11$ & $-0,08$ & 0,30 & $-0,33^{*}$ & 0,04 & $-0,14$ \\
\hline & 4.10 & 5,9 & umc1532 & $-0,09$ & $-0,13$ & $-0,09$ & $-0,07$ & 0,20 & $-0,35^{*}$ & 0,07 & $-0,12$ \\
\hline & 4.10 & 6,3 & umc1109 & $-0,04$ & 0,03 & $-0,21$ & $-0,11^{*}$ & 0,23 & $-0,08$ & $-0,11$ & $-0,17^{*}$ \\
\hline & 4.11 & 6,2 & bnlg1337 & $-0,06$ & 0,03 & $-0,02$ & $-0,07^{\star}$ & 0,31 & 0,00 & 0,15 & $-0,03$ \\
\hline & 4.11 & --- & umc1197 & $-0,03$ & $-0,06$ & $-0,01$ & $-0,15^{\star * \star *}$ & 0,20 & 0,13 & $-0,05$ & $-0,22^{*}$ \\
\hline \multirow[t]{16}{*}{5} & 5.00 & 40,7 & bnlg1006 & $-0,42$ & 0,11 & $0,44^{*}$ & $-0,13$ & $-0,36$ & 0,21 & $0,95^{\star * *}$ & $-0,13$ \\
\hline & 5.02 & 8,3 & umc1587 & $-0,80^{* *}$ & $-0,18^{*}$ & $0,55^{*}$ & 0,04 & $-0,77^{\star *}$ & $-0,19^{*}$ & $0,90^{* * *}$ & $-0,03$ \\
\hline & $5.03-04$ & 5,3 & phi0113 & $-0,68^{*}$ & $-0,08$ & $0,73^{* *}$ & 0,06 & $-0,24$ & $-0,15$ & $1,41^{* * * *}$ & $-0,01$ \\
\hline & 5.03 & 16,1 & bnlg1879 & $-0,78^{*}$ & $-0,07$ & $0,90^{* *}$ & 0,02 & $-0,28$ & $-0,31^{\star *}$ & $1,49^{* * *}$ & $-0,02$ \\
\hline & 5.03 & 14,1 & umc1056 & $-0,34$ & $0,28^{* *}$ & $0,65^{*}$ & $-0,12$ & 0,42 & $0,15^{\star}$ & $1,02^{* *}$ & $-0,18^{*}$ \\
\hline & 5.03 & 9,7 & bnlg1902 & $-0,19$ & $0,28^{* *}$ & $0,57^{*}$ & $-0,14$ & $0,75^{*}$ & $0,38^{*}$ & $0,88^{* *}$ & $-0,21^{*}$ \\
\hline & 5.04 & 17,7 & dupssr10 & 0,24 & 0,27 & $0,66^{* * *}$ & $-0,27^{\star}$ & $1,34^{* * *}$ & 0,19 & $1,11^{* \star *}$ & $-0,35^{\star}$ \\
\hline & 5.04 & 3,8 & umc1221 & 0,49 & $-0,16$ & $0,50^{* *}$ & $-0,24^{\star *}$ & $1,28^{* * *}$ & $-0,28$ & $1,07^{\star *}$ & $-0,31^{* *}$ \\
\hline & 5.05 & 23,5 & mmc0081 & 0,23 & $-0,02$ & $0,47^{*}$ & $-0,26^{\star *}$ & $1,02^{* *}$ & $-0,13$ & $0,95^{\star *}$ & $-0,37^{* *}$ \\
\hline & 5.06 & 2,1 & umc1019 & 0,49 & $-0,06$ & 0,27 & 0,01 & $1,45^{\star *}$ & $-0,13$ & $0,76^{* *}$ & $-0,06$ \\
\hline & 5.06 & 2,3 & mmc0481 & 0,37 & $-0,13$ & $0,46^{*}$ & 0,08 & $1,29^{\star \star}$ & $-0,18$ & $1,02^{\star \star \star}$ & 0,01 \\
\hline & $5.05-06$ & 1,6 & bnlg278 & 0,33 & $-0,17^{*}$ & 0,31 & 0,12 & $1,21^{* *}$ & $-0,19$ & $0,78^{* *}$ & 0,08 \\
\hline & 5.06 & 0,1 & umc1680 & $0,52^{*}$ & $-0,16$ & 0,22 & 0,16 & $1,37^{* *}$ & $-0,15$ & $0,70^{* *}$ & 0,13 \\
\hline & 5.06 & 21,9 & umc1524 & $0,54^{*}$ & $-0,17^{*}$ & 0,21 & 0,16 & $1,35^{\star \star}$ & $-0,16$ & $0,65^{\star *}$ & 0,13 \\
\hline & 5.07 & 32,3 & phi0128 & 0,50 & $-0,07$ & $0,27^{*}$ & $0,10^{* *}$ & 0,79 & $-0,12$ & $0,60^{* *}$ & $0,13^{\star *}$ \\
\hline & 5.09 & --- & umc1153 & 0,23 & $0,22^{*}$ & $-0,03$ & $-0,09$ & 0,38 & $0,39^{* *}$ & $-0,01$ & $-0,08$ \\
\hline \multirow[t]{12}{*}{6} & 6.00 & 34,3 & phi0126 & $-0,32^{*}$ & $-0,07$ & 0,12 & $-0,35^{*}$ & $-0,72^{* *}$ & $-0,08$ & 0,03 & $-0,47^{*}$ \\
\hline & 6.02 & 14,3 & bnlg1371 & $-0,77^{* * *}$ & 0,20 & $0,32^{* *}$ & 0,00 & $-1,15^{\star \star *}$ & 0,09 & 0,33 & $-0,01$ \\
\hline & 6.01 & 9,9 & phi0077 & $-0,87^{\star * *}$ & $-0,05$ & $0,53^{* *}$ & $-0,04$ & $-1,41^{* * *}$ & $-0,14$ & $0,93^{* *}$ & $-0,03$ \\
\hline & 6.02 & 0,8 & umc1006 & $-0,20$ & 0,21 & 0,02 & $-0,07$ & $-0,74^{* *}$ & 0,17 & 0,17 & $-0,08$ \\
\hline & 6.02 & 13,1 & umc1257 & $-0,36^{*}$ & $0,28^{*}$ & 0,02 & $-0,06$ & $-0,92^{\star * *}$ & 0,28 & 0,22 & $-0,08$ \\
\hline & 6.03 & 13,9 & umc1887 & $-0,58^{*}$ & $0,20^{* *}$ & 0,27 & 0,07 & $-0,82^{* *}$ & 0,12 & $0,54^{\star *}$ & 0,02 \\
\hline & 6.04 & 18,9 & umc1614 & $-0,54^{* *}$ & $0,20^{*}$ & $0,41^{*}$ & $-0,07$ & $-0,45^{\star}$ & 0,14 & $0,72^{* * *}$ & $-0,08$ \\
\hline & 6.05 & 22,4 & nc0013 & $-0,30$ & 0,10 & $0,58^{* *}$ & 0,07 & $-0,11$ & $-0,06$ & $0,68^{*}$ & $-0,10$ \\
\hline & 6.06 & 21,2 & umc1520 & $-0,56^{*}$ & $-0,05$ & $0,46^{*}$ & $-0,08$ & $-0,62^{*}$ & $-0,12$ & $0,69^{*}$ & $-0,24^{\star}$ \\
\hline & 6.07 & 11,5 & bnlg1759 & $-0,17$ & $-0,03$ & 0,51 & $-0,17^{*}$ & $-0,54$ & $-0,15$ & $0,69^{* *}$ & $-0,29^{*}$ \\
\hline & 6.07 & 2,6 & umc1653 & 0,17 & $-0,10$ & $0,60^{* *}$ & $-0,05$ & $-0,13$ & $-0,32$ & $0,93^{* * *}$ & $-0,08$ \\
\hline & 6.08 & --- & umc1127 & 0,15 & $-0,19^{*}$ & $0,48^{*}$ & $-0,01$ & $-0,02$ & $-0,37^{*}$ & $0,77^{\star \star}$ & 0,00 \\
\hline
\end{tabular}


Tabela 16. Estimativas e significâncias dos coeficientes de regressão parciais ( $\beta^{\prime}$ s) para os caracteres altura da espiga $\left(\mathrm{cm}\right.$ planta $\left.{ }^{-1}\right)$ e altura da planta $\left(\mathrm{cm}\right.$ planta $\left.{ }^{-1}\right)$.

\begin{tabular}{|c|c|c|c|c|c|c|c|c|c|c|c|}
\hline \multirow{2}{*}{$\mathrm{C}^{\mathrm{a}}$} & \multirow{2}{*}{ Bin } & \multirow{2}{*}{$\mathrm{cM}^{\mathrm{b}}$} & \multirow{2}{*}{ Marcador } & \multicolumn{4}{|c|}{ Altura da espiga (AE) } & \multicolumn{4}{|c|}{ Altura da planta (AP) } \\
\hline & & & & $\beta_{1}{ }^{c}$ & $\beta_{2}$ & $\beta_{3}$ & $\beta_{4}$ & $\beta_{1}$ & $\beta_{2}$ & $\beta_{3}$ & $\beta_{4}$ \\
\hline \multirow[t]{9}{*}{7} & 7.00 & 34,5 & umc1426 & $-0,33$ & 0,01 & 0,04 & $-0,01$ & $-0,29$ & $-0,22$ & 0,04 & $-0,05$ \\
\hline & 7.01 & 7,6 & umc1632 & $-1,86^{* *}$ 。 & 0,09 & $0,83^{* * *}$ & 0,00 & $-2,18^{* *}$ & $-0,12$ & $1,19^{\star \star \star *}$ & $-0,07$ \\
\hline & 7.01 & 0,1 & umc1409 & $-1,86^{\star * *}$ & 0,18 & $0,91^{* * *}$ & 0,01 & $-2,16^{* * *}$ & 0,04 & $1,49^{\star * * * *}$ & $-0,06$ \\
\hline & 7.02 & 28,3 & bnlg1094 & $-1,84^{* *}$ & 0,19 & $0,90^{* * *}$ & 0,01 & $-2,12^{\star \star \star}$ & 0,05 & $1,48^{* * * * *}$ & $-0,07$ \\
\hline & 7.03 & 39,7 & bnlg0434 & $-1,28^{\star * *}$ & 0,13 & $0,90^{\star \star *}$ & 0,06 & $-1,90^{\star \star \star}$ & 0,15 & $1,58^{* * *}$ & 0,22 \\
\hline & 7.04 & 32,6 & dupssr13 & $-0,85^{\star}$ & 0,06 & $0,33^{*}$ & 0,09 & $-1,49^{\star *}$ & $0,32_{o \circ}$ & $0,50^{*}$ & 0,17 \\
\hline & 7.05 & 3,2 & umc1154 & $-0,31$ & $0,30^{*}$ & $-0,21$ & $-0,17$ & $-0,76^{*}$ & 0,18 & $-0,44^{*}$ & $-0,31^{* *}$ \\
\hline & 7.05 & 6,7 & umc1407 & $-0,45^{\star \star}$ & $0,24^{\star \star}$ & $-0,11^{*}$ & 0,02 & $-1,08^{* \star *}$ & $0,41^{* \star * *}$ & $-0,20$ & $-0,03$ \\
\hline & 7.06 & --- & phi0116 & $-0,12$ & $0,30^{*}$ & 0,02 & 0,08 & $-0,53$ & $0,50^{\star *}$ & $-0,16$ & 0,10 \\
\hline \multirow[t]{11}{*}{8} & 8.01 & 12,1 & umc1139 & 0,36 & $-0,17$ & $0,34^{* *}$ & $0,22^{*}$ & 0,57 & $-0,14$ & $0,52^{*}$ & 0,22 \\
\hline & 8.00 & 14,5 & phi420701 & $0,67^{*}$ & $-0,30^{*}$ & $0,39^{*}$ & 0,09 & $0,72^{*}$ & $-0,30$ & 0,37 & 0,16 \\
\hline & 8.02 & 11,9 & phi0119 & 0,16 & $-0,27^{*}$ & $0,40^{*}$ & 0,03 & $-0,11$ & $-0,24$ & $0,49^{*}$ & $0,14^{*}$ \\
\hline & 8.03 & 22,0 & umc1034 & $-0,25$ & $-0,14$ & $0,33^{*}$ & $-0,09$ & $-0,58$ & $-0,15$ & $0,42^{*}$ & $-0,01$ \\
\hline & 8.04 & 24,4 & bnlg1863 & $-0,37$ 。 & $-0,14$ & $0,52^{*}$ & $-0,02$ & $-1,24^{*}$ & $-0,09$ & 0,50 & $-0,03$ \\
\hline & 8.05 & 37,4 & bnlg1176 & $-0,47$ & 0,08 & $0,44^{*}$ & $-0,15$ & $-1,41^{\star \star}$ & $0,22^{*}$ & $0,50^{*}$ & $-0,15$ \\
\hline & 8.06 & 12,5 & bnlg1607 & $-0,06$ & 0,20 & 0,28 & 0,01 & $-0,48$ & $0,27^{*}$ & $0,47^{*}$ & $-0,03$ \\
\hline & 8.07 & 8,9 & bnlg1823 & 0,18 & 0,03 & 0,24 & 0,00 & $-0,04$ & $-0,07$ & $0,38^{*}$ & $-0,05$ \\
\hline & 8.08 & 12,1 & umc1005 & 0,20 & 0,06 。 & 0,02 & $-0,03$ & $-0,06$ & 0,07 & $-0,04$ & $-0,07$ \\
\hline & 8.09 & 15,6 & dupssr14 & $0,47^{\star}$ & $-0,17^{*}$ & 0,05 & 0,11 & $-0,06$ & 0,02 & 0,12 & 0,09 \\
\hline & 8.09 & --- & bnlg1131 & $0,53^{*}$ & 0,07 & 0,08 & 0,16 & 0,13 & 0,06 & 0,05 & $0,41^{*}$ \\
\hline \multirow[t]{10}{*}{9} & 9.02 & 2,4 & umc1170 & $-0,50^{*}$ & $-0,03$ & $0,56^{*}$ & $-0,19$ & $-1,13^{*}$ & $-0,07$ & $0,87^{*}$ & $-0,36^{*}$ \\
\hline & 9.02 & 11,8 & dupssr06 & $-0,54^{*}$ & $-0,07$ & $0,51^{*}$ & $-0,16^{*}$ & $-1,10^{* \star *}$ & $-0,18$ & $0,78^{*}$ & $-0,33^{*}$ \\
\hline & 9.02 & 4,7 & bnlg1401 & $-0,64^{\star \star}$ & 0,01 & $0,77^{\star *}$ & $-0,21^{\star *}$ & $-1,26^{\star * *}$ & $-0,05$ & $1,11^{\star \star}$ & $-0,40^{* * *}$ \\
\hline & 9.02 & 14,0 & umc1893 & $-0,68^{\star \star}$ & $-0,03$ & $0,52^{*}$ & $-0,13^{\star}$ & $-1,16^{\star *}$ & $-0,18$ & $0,82^{*}$ & $-0,29^{\star *}$ \\
\hline & 9.03 & 12,3 & bnlg0430 & $-0,71^{\star *}$ & 0,05 & 0,25 & $-0,13^{*}$ & $-1,16^{* *}$ & 0,05 & $0,38^{*}$ & $-0,21^{*}$ \\
\hline & 9.04 & 5,6 & umc1107 & $-0,71^{\star * *}$ & 0,13 & $0,52^{* *}$ & $-0,09$ & $-1,13^{\star *}$ & 0,22 & $0,70^{\star *}$ & $-0,09$ \\
\hline & 9.05 & 34,1 & bnlg1012 & $-0,63^{*}$ & 0,14 & $0,48^{*}$ & $-0,06$ & $-1,12^{*}$ & 0,09 & $0,63^{*}$ & $-0,04$ \\
\hline & 9.06 & 13,8 & umc1733 & 0,21 & $-0,14$ & 0,57 & 0,02 & 0,26 & $0,20^{\star *}$ & 0,34 & 0,09 \\
\hline & $9.07-08$ & 7,8 & bnlg0619 & $-0,34$ 。 & $-0,09$ & $0,34^{*}$ & $-0,15^{\star}$ & $-0,45_{\circ 00}$ & 0,04 & $-0,01$ & $-0,17^{*}$ \\
\hline & 9.07 & --- & bnlg0128 & $-0,58$ & 0,03 & 0,26 & $-0,08$ & $-0,99_{0}$ & 0,01 & 0,03 & $-0,15$ \\
\hline \multirow[t]{12}{*}{10} & 10.00 & 9,8 & phi0117 & $-0,06$ & 0,14 & $0,32^{*}$ & 0,12 & $-0,09$ & 0,24 & $0,48^{* *}$ & 0,21 \\
\hline & 10.01 & 6,3 & umc1319 & $-0,04$ & 0,16 & $0,56^{\star *}$ & 0,05 & 0,34 & $0,37^{*}$ & $0,75^{\star \star \star *}$ & 0,15 \\
\hline & 10.02 & 40,7 & bnlg1451 & 0,01 。 & $0,20^{*}$ & $0,45^{\star *}$ & $-0,14$ & 0,21 & $0,36^{\star *}$ & $0,52^{* \star}$ & $-0,16^{*}$ \\
\hline & 10.03 & 7,3 & bnlg0640 & $-0,10$ & $-0,23^{*}$ & 0,48 & $-0,02$ & 0,27 & $-0,32^{*}$ & 0,75 & $-0,13$ \\
\hline & 10.04 & 27,0 & bnlg1526 & 0,13 & $-0,17$ & 0,51 & $-0,03$ & 0,28 & $-0,12$ & $0,96^{*}$ & $-0,11$ \\
\hline & 10.05 & 7,0 & umc1930 & $-0,03$ & $0,30^{*}$ & $0,84^{* * * * *}$ & $-0,12$ & 0,49 & 0,20 & $1,25^{\star \star *}$ & $-0,25^{\star}$ \\
\hline & 10.05 & 12,1 & umc1506 & $-0,68$ & $0,34^{\star *}$ & $1,08^{\star * \star *}$ & 0,00 & $-0,44$ & $0,33^{*}$ & $1,55^{\star *}$ & $-0,12$ \\
\hline & 10.07 & 0,2 & umc1196 & $-1,50^{\star *}$ & 0,14 & $1,25^{\star *}$ & 0,05 & $-1,32^{\star *}$ & $0,17^{*}$ & $1,65^{\star \star \star}$ & 0,09 \\
\hline & 10.07 & 0,1 & umc1038 & $-1,59^{\star *}$ & 0,17 & $1,32^{\star * *}$ & 0,01 & $-1,23^{*}$ & 0,03 & $1,77^{* * *}$ & 0,10 \\
\hline & 10.07 & 0,1 & umc2021 & $-1,45^{\star \star}$ & 0,16 & $1,21^{* *}$ & 0,05 & $-1,28^{*}$ & $0,20^{*}$ & $1,68^{* * *}$ & 0,05 \\
\hline & 10.07 & 1,4 & umc1569 & $-1,16^{*}$ & 0,13 & $1,34^{\star * *}$ & $0,11^{*}$ & $-0,90$ & 0,17 & $1,94^{* * *}$ & 0,17 \\
\hline & 10.07 & --- & bnlg1839 & $-1,61^{\star *}$ & 0,09 & $1,34^{\star * *}$ & 0,03 & $-1,41^{*}$ & 0,12 & $1,87^{* \star * *}$ & $-0,01$ \\
\hline
\end{tabular}

a número do cromossomo; ${ }^{\mathrm{b}}$ distância em centiMorgam (cM) entre locos adjacentes; ${ }^{\mathrm{c}}$ Níveis de significância para os efeitos dos contrastes: * $P \leq 0,05 ;{ }^{* *} \mathrm{P} \leq 0,01 ;{ }^{* * *} \mathrm{P} \leq 0,001$; ${ }^{* * *} \mathrm{P} \leq 0,0001 \mathrm{e}$ ${ }^{* \star * * *} P \leq 0,00001$; níveis de significância para as interações contrastes por ambientes: 0 $P \leq 0,05$; oo $P \leq 0,01$; $000 P \leq 0,001$; $0000 P \leq 0,0001$. 
Tabela 17. Estimativas e significâncias dos coeficientes de regressão parciais ( $\beta^{\prime} \mathbf{s}$ ) para os caracteres posição relativa da espiga (AE/AP) e intervalo de florescimento (FM-FF)..

\begin{tabular}{|c|c|c|c|c|c|c|c|c|c|c|c|}
\hline \multirow{2}{*}{$C^{a}$} & \multirow{2}{*}{ Bin } & \multirow{2}{*}{$\mathrm{cM}^{\mathrm{b}}$} & \multirow{2}{*}{ Marcador } & \multicolumn{4}{|c|}{ Posição relativa da espiga (PRE) ${ }^{d}$} & \multicolumn{4}{|c|}{ Intervalo de florescimento (IF $)^{\mathrm{e}}$} \\
\hline & & & & $\beta_{1}{ }^{\mathrm{c}}$ & $\beta_{2}$ & $\beta_{3}$ & $\beta_{4}$ & $\beta_{1}$ & $\beta_{2}$ & $\beta_{3}$ & $\beta_{4}$ \\
\hline \multirow{19}{*}{1} & 1.01 & 10.7 & umc1177 & -1.95 & -0.51 & 0.35 & 0.01 & 0,52 & 1,15 & $-0,48$ & $-0,27$ \\
\hline & 1.01 & 0.9 & bnlg1014 & $-1.92_{0}$ & -0.48 & 0.62 & 0.14 & 0,72 & $-0,24$ & 1,04 & 0,40 \\
\hline & 1.00 & 19.8 & umc1106 & $-1.52_{o o}$ & -0.15 & 0.50 & 0.11 & $-0,87$ & 0,34 & 2,23 & 0,16 \\
\hline & 1.02 & 11.4 & bnlg1627 & -2.08 & -0.08 & 0.79 & -0.03 & 1,98 & 0,98 & 1,18 & $-1,59$ \\
\hline & 1.02 & 5.7 & bnlg1083 & $-3.68^{* *}$ & -0.27 & 0.27 & 0.06 & 1,41 & $-0,52$ & $-0,83$ & 0,74 \\
\hline & 1.03 & 9.9 & umc1073 & $-3.47^{\star *}$ & $-0.75^{*}$ & -0.28 & 0.14 & 1,60 & $-2,17^{*}$ & $-0,22$ & 1,86 \\
\hline & 1.03 & 8.7 & umc1021 & -2.61 & $-0.18_{0 \circ}$ & -0.51 & 0.36 & $-1,13$ & $-0,24$ & 0,16 & 2,49 \\
\hline & 1.04 & 21.9 & bnlg2238 & -0.46 & $-0.74^{\star *}$ & 0.11 & -0.07 & 6,00 & 1,94 & $-1,45$ & $-0,81$ \\
\hline & 1.05 & 13.1 & umc2025 & $1.85_{00}$ & 0.51 & $0.78^{*}$ & -0.21 & 3,88 & 0,30 & $-2,93$ & $-1,28$ \\
\hline & 1.05 & 10.7 & umc1601 & $1.05^{\star}$ & -0.47 & 0.17 & 0.06 & $-0,52$ & $-0,95$ & $-2,70$ & $-0,41$ \\
\hline & 1.06 & 5.7 & umc1508 & 1.18 & 0.03 & 1.16 & -0.02 & $-3,59$ & $-1,35$ & $-1,14$ & 0,20 \\
\hline & 1.06 & 6.8 & bnlg1598 & 1.52 & 0.22 & 1.30 & -0.17 & $-2,48$ & $-0,84$ & 0,48 & 0,30 \\
\hline & 1.06 & 25.6 & umc1035 & $1.88^{*}$ & 0.45 & 1.07 & -0.12 & $-0,64$ & 0,43 & $-1,84$ & $-0,43$ \\
\hline & 1.07 & 15.9 & bnlg0615 & $1.01_{000}$ & 0.20 & 1.50 & -0.20 & 2,09 & $-0,72$ & $-0,48$ & 0,81 \\
\hline & 1.10 & 24.1 & umc1431 & 0.82 & 0.07 & -0.09 & 0.16 & $-4,68$ & 0,15 & 2,68 & 0,52 \\
\hline & 1.08 & 24.2 & phi0037 & 0.10 & -0.35 & $1.16^{*}$ & 0.36 & $-0,20$ & 1,41 & $-0,64$ & 0,60 \\
\hline & 1.11 & 11.6 & phi0120 & 0.81 & 0.18 & 0.63 & -0.12 & $-2,41$ & $-0,07$ & 0,51 & $-0,17$ \\
\hline & 1.11 & 17.6 & umc1630 & 1.15 & 0.20 & 0.45 & -0.04 & $-1,37$ & $-0,90$ & $-1,78$ & $-0,05$ \\
\hline & 1.12 & --- & umc1605 & $1.17^{\star \star}$ & 0.34 & 0.41 & 0.19 & $-3,31^{*}$ & $-3,38$ & 0,15 & 2,21 \\
\hline \multirow[t]{19}{*}{2} & 2.01 & 4.6 & umc1165 & -0.82 & $-0.95^{\star *}$ & 0.32 & 0.34 & $-3,16$ & $-0,14$ & 5,92 & 0,31 \\
\hline & 2.01 & 1.3 & bnlg1338 & -1.51 & $-0.96^{\star * *}$ & 0.76 & 0.29 & $-0,53$ & $-1,81$ & 6,53 & 1,06 \\
\hline & 2.01 & 1.5 & umc1227 & -1.06 & $-0.82^{* *}$ & 0.13 & 0.30 & 0,04 & $-2,29$ & 6,45 & 1,69 \\
\hline & 2.02 & 2.8 & bnlg1017 & -1.13 & $-0.79^{\star}$ & 0.18 & 0.310 & $-1,22$ & $-2,99$ & 4,39 & 1,32 \\
\hline & 2.02 & 12.9 & umc1265 & -0.53 & $-0.56^{*}$ & 0.21 & 0.24 & $-2,06$ & $-2,46$ & 3,75 & 1,67 \\
\hline & 2.02 & 8.6 & umc1934 & -0.70 & -0.32 & -0.18 & 0.34 & $-9,98^{* *}$ & $-1,50$ & $7,04^{*}$ & 0,07 \\
\hline & 2.02 & 4.0 & bnlg0125 & -0.30 & 0.25 & -0.03 & 0.36 & $-6,08^{*}$ & $-1,42$ & $8,54^{*}$ & 0,69 \\
\hline & 2.03 & 0.9 & umc1845 & -0.78 & 0.45 & 0.36 & 0.05 & $-9,86^{\star * *}$ & $-0,20$ & $9,90^{*}$ & 0,93 \\
\hline & 2.03 & 2.5 & umc1776 & -0.64 & 0.07 & 0.61 & 0.00 & $-5,43^{*}$ & 3,03 & $9,72^{*}$ & $-0,13$ \\
\hline & 2.03 & 7.1 & bnlg2248 & -0.91 & 0.05 & 0.13 & 0.13 & $-10,25^{\star \star}$ & $-0,88$ & $10,56^{*}$ & 0,68 \\
\hline & 2.03 & 32.2 & bnlg0381 & 0.18 & 0.09 & 0.46 & 0.09 & $-4,30$ & $-0,80$ & $9,37^{* *}$ & 0,76 \\
\hline & 2.04 & 10.1 & bnlg0166 & -0.29 & 0.66 & 0.91 & 0.21 & $-1,88$ & 2,28 & $4,98^{*}$ & $-2,08$ \\
\hline & 2.05 & 19.5 & dupssr21 & -1.04 & 0.47 & 1.07 & 0.36 & $-1,96$ & 0,75 & 2,37 & $-1,38$ \\
\hline & 2.06 & 78.3 & bnlg1396 & -1.54 & 0.28 & 0.51 & -0.18 & 5,28 & $-1,23$ & $-1,02$ & 0,47 \\
\hline & 2.07 & 6.3 & umc1560 & $1.55^{\star}$ & $-0.46_{00}$ & 0.07 & 0.41 & $-5,46$ & 1,04 & 2,60 & 0,69 \\
\hline & 2.08 & 6.5 & umc1464 & 0.44 & $-0.77_{000}$ & 0.19 & 0.16 & $-1,82$ & $-0,82$ & $4,79^{*}$ & 0,57 \\
\hline & 2.08 & 6.9 & umc1633 & $1.05^{\star}$ & -0.21 。 & 0.17 & 0.12 & 0,35 & 0,27 & 3,35 & 0,38 \\
\hline & 2.09 & 4.9 & umc1230 & $0.80^{*}$ & $-0.08_{0 \circ}$ & -0.20 & -0.01 & 2,35 & $-0,66$ & 1,45 & $2,93^{\text {** }}$ \\
\hline & 2.09 & --- & bnlg1520 & 0.86 & 0.26 & -0.14 & -0.22 & 3,61 & 0,45 & 1,34 & $2,33^{*}$ \\
\hline \multirow[t]{13}{*}{3} & 3.01 & 17.4 & umc1394 & -1.33 & -0.06 & -0.07 & 0.12 & $-0,15$ & $-0,19$ & 1,30 & $-1,53$ \\
\hline & 3.03 & 27.7 & bnlg1144 & $-1.55^{\star}$ & 0.55 & 1.16 & -0.04 & $-4,35$ & $-0,20$ & 1,75 & $-1,61$ \\
\hline & 3.04 & 7.8 & bnlg1452 & 0.19 & 0.01 & -0.43 & -0.11 & $-4,17$ & $-1,87$ & 1,65 & 1,21 \\
\hline & 3.04 & 12.1 & bnlg602 & -0.85 & 0.27 & -0.56 & 0.08 & $-3,27$ & $-0,44$ & 1,72 & 0,33 \\
\hline & 3.05 & 1.8 & bnlg0420 & 0.87 & 0.71 & -1.17 & 0.04 & $-2,24$ & $-1,58^{*}$ & 1,01 & 2,06 \\
\hline & 3.05 & 34.1 & mmc0022 & $1.19^{*}$ & 0.62 & -0.81 & -0.12 & $-1,17$ 。 & $-1,90^{*}$ & 1,83 & 1,67 \\
\hline & 3.06 & 28.6 & bnlg1798 & 1.07 & 0.02 & 0.31 & 0.26 & 0,82 & $-2,61$ & $-2,78$ & 1,26 \\
\hline & 3.07 & 3.3 & umc1690 & 0.45 & 0.03 & 1.15 & -0.11 & $-6,40$ & 1,31 & $-0,49$ & $-2,01$ \\
\hline & 3.07 & 16.0 & umc1659 & -0.24 & -0.30 & $1.55^{\star *}$ & -0.06 & $-6,22$ & 1,10 & 0,35 & $-0,93$ \\
\hline & 3.08 & 14.1 & umc1320 & $-2.68^{\star *}$ & -0.17 & 0.98 & -0.13 & $-7,02$ & 1,99 & 1,37 & $-1,26$ \\
\hline & 3.09 & 2.9 & bnlg1536 & $-2.12^{*}$ & 0.13 & 0.02 & 0.17 & $-2,59$ & 0,85 & 1,84 & 0,11 \\
\hline & 3.09 & 26.7 & bnlg1754 & $-1.60_{\circ o}$ & 0.37 & 0.15 & 0.23 & 0,37 & $3,18^{*}$ & 1,71 & $-2,31$ \\
\hline & 3.10 & --- & bnlg1098 & -1.34 & 0.19 & -1.18 & $-0.43^{*}$ & 0,90 。 & $3,28^{*}$ & 2,34 & 0,92 \\
\hline
\end{tabular}


Tabela 17. Estimativas e significâncias dos coeficientes de regressão parciais ( $\beta^{\prime} \mathbf{s}$ ) para os caracteres posição relativa da espiga (AE/AP) e intervalo de florescimento (FM-FF)..

\begin{tabular}{|c|c|c|c|c|c|c|c|c|c|c|c|}
\hline \multirow{2}{*}{$\mathrm{C}^{\mathrm{a}}$} & \multirow{2}{*}{ Bin } & \multirow{2}{*}{\multicolumn{2}{|c|}{$\mathrm{cM}^{\mathrm{b}}$ Marcador }} & \multicolumn{4}{|c|}{ Posição relativa da espiga (PRE) } & \multicolumn{4}{|c|}{ Intervalo de florescimento (IF) ${ }^{\mathrm{e}}$} \\
\hline & & & & $\beta_{1}{ }^{c}$ & $\beta_{2}$ & $\beta_{3}$ & $\beta_{4}$ & $\beta_{1}$ & $\beta_{2}$ & $\beta_{3}$ & $\beta_{4}$ \\
\hline \multirow[t]{19}{*}{4} & 4.01 & 55.7 & umc1276 & 0.47 & 0.18 & 1.08 & 0.07 & $-8,93^{\star *}$ & $-2,24$ & $7,69^{* *}$ & 1,95 \\
\hline & 4.04 & 3.4 & umc1652 & $1.46^{\star}$ & -0.03 & 1.26 & -0.10 & $6,78^{* *}$ & 0,71 & 0,07 & $-1,04$ \\
\hline & 4.05 & 0.1 & phi0026 & $1.58^{* *}$ & -0.13 & 0.91 & -0.04 & $7,58^{* *}$ & 1,76 & 1,92 & $-1,14$ \\
\hline & 4.05 & 1.7 & umc1088 & $2.38^{* *}$ & -0.18 & 0.91 & 0.03 & $6,24^{*}$ & 1,59 & 1,27 & $-1,48$ \\
\hline & 4.06 & 35.6 & bnlg0252 & $1.49^{*}$ & -0.09 & 0.56 & -0.11 & $5,73^{*}$ & $1,91^{*}$ & 0,93 & $-0,37$ \\
\hline & 4.07 & 5.1 & bnlg2291 & 0.42 & 0.12 & 0.85 & -0.10 & $6,93^{*}$ & 0,18 & $-0,40$ & $-0,77$ \\
\hline & 4.07 & 18.0 & dupssr34 & -0.42 & 0.55 & 0.29 & -0.07 & $5,43^{*}$ & 1,47 & $-0,22$ & $-0,63$ \\
\hline & 4.08 & 2.0 & bnlg2244 & -0.55 & 0.37 & 0.29 & 0.22 & 6,34 & $2,63^{*}$ & $-0,21$ & $-2,59^{* *}$ \\
\hline & 4.08 & 4.7 & bnlg2162 & -0.47 & 0.37 & 0.00 & 0.14 & $5,92^{*}$ & $3,32^{*}$ & $-0,97$ & $-2,40^{*}$ \\
\hline & 4.08 & 4.6 & umc1086 & -0.93 & 0.21 & -0.21 & 0.60 & 3,42 & $2,76^{*}$ & $-1,25$ & $-1,39$ \\
\hline & 4.08 & 11.5 & umc1051 & -0.41 & -0.09 & -0.30 & 0.54 & 6,42 & 2,36 & $-2,47$ & $-1,63^{\text {** }}$ \\
\hline & 4.09 & 15.6 & umc1989 & -0.22 & $0.38^{*}$ & -0.79 & 0.08 & $5,21^{*}$ & 2,47 & $-1,59$ & $-1,18$ \\
\hline & 4.09 & 0.6 & phi314704 & -0.75 & 0.27 & -0.89 & -0.06 & $-1,23$ & $0,30_{\circ}$ & $-1,64$ & $-0,08$ \\
\hline & 4.11 & 0.2 & bnlg0589 & -0.17 & 0.43 & -0.52 & -0.04 & $-3,60^{*}$ & $-0,89$ & $-0,83$ & $-0,30$ \\
\hline & 4.10 & 0.2 & umc1503 & $-1.11^{*}$ & 0.18 & -0.68 & -0.04 & $-1,17$ & 0,11 。 & $-1,58$ & 0,00 \\
\hline & 4.10 & 5.9 & umc1532 & $-1.00^{*}$ & 0.21 & -0.61 & -0.02 & $-1,67$ & $0,08_{0}$ & $-1,75$ & $-0,03$ \\
\hline & 4.10 & 6.3 & umc1109 & -0.80 & 0.32 & -0.77 & -0.09 & $-1,55$ & 1,58 & $-0,47$ & $-0,42$ \\
\hline & 4.11 & 6.2 & bnlg1337 & -1.08 & 0.14 & -0.49 & -0.29 & $-1,32$ & $0,42_{o \circ}$ & $-0,24$ & 0,70 \\
\hline & 4.11 & --- & umc1197 & -0.73 & $-0.66^{*}$ & 0.09 & -0.14 & $-2,01$ & 1,49 & 1,73 & $-1,13$ \\
\hline \multirow[t]{16}{*}{5} & 5.00 & 40.7 & bnlg1006 & $-1.30_{\circ o}$ & -0.01 & -0.34 & -0.28 & $-3,03$ & 2,98 & $-0,11$ & $-0,96$ \\
\hline & 5.02 & 8.3 & umc1587 & $-1.89^{*}$ & -0.41 & 0.31 & 0.27 & $-0,29$ & $-2,88$ & $4,14^{\star}$ & $-1,18$ \\
\hline & $5.03-04$ & 5.3 & phi0113 & $-2.67^{\star}$ & 0.05 & -0.12 & 0.27 & 3,020 & $-2,62$ & 3,71 & 0,53 \\
\hline & 5.03 & 16.1 & bnlg1879 & $-3.05^{\star}$ & 0.50 & 0.45 & 0.16 & 0,38 & $-1,56$ & 3,71 & $-0,84$ \\
\hline & 5.03 & 14.1 & umc1056 & $-2.78^{*}$ & $0.97^{*}$ & 0.53 & -0.12 & 4,43 & $-0,73$ & $-3,12$ & $-0,88$ \\
\hline & 5.03 & 9.7 & bnlg1902 & $-2.88^{* *}$ & 0.38 & 0.47 & -0.08 & 5,04 & $-0,58$ & $-4,28$ & $-0,96$ \\
\hline & 5.04 & 17.7 & dupssr10 & $-2.35^{\star}$ & $0.87^{*}$ & 0.31 & -0.37 & $-1,78$ 。 & $-1,36$ & 0,13 & $-0,77$ \\
\hline & 5.04 & 3.8 & umc1221 & -0.95 & -0.04 & -0.30 & $-0.33^{*}$ & 4,80 。 & 0,59 & $-2,83$ & $-0,83$ \\
\hline & 5.05 & 23.5 & $\mathrm{mmc} 0081$ & -1.55 & 0.30 & -0.14 & -0.31 & $4,26_{\circ \circ}$ & $-0,24$ & $-2,36 。$ & $-0,62$ \\
\hline & 5.06 & 2.1 & umc1019 & -1.44 & 0.09 & -0.63 & 0.25 & 6,31 & 3,25 & $-0,03$ & $-1,07$ \\
\hline & 5.06 & 2.3 & $\mathrm{mmc} 0481$ & $-1.62^{*}$ & -0.14 & -0.40 & 0.39 & 5,20 & 2,78 & 0,58 & $-0,94$ \\
\hline & $5.05-06$ & 1.6 & bnlg278 & $-1.60^{*}$ & -0.33 & -0.53 & 0.43 & 3,77 & 1,61 & $-0,26$ & $-0,49$ \\
\hline & 5.06 & 0.1 & umc1680 & -1.13 & -0.38 & -0.79 & 0.47 & 3,78 & 2,37 & 0,87 & $-1,50$ \\
\hline & 5.06 & 21.9 & umc1524 & -0.96 & -0.37 & -0.64 & 0.48 & 3,40 & 2,33 & 1,11 & $-1,51$ \\
\hline & 5.07 & 32.3 & phi0128 & 0.39 & 0.02 & -0.32 & 0.17 & 3,14 & 1,41 & 1,03 & $-0,72$ \\
\hline & 5.09 & --- & umc1153 & 0.17 & 0.10 & -0.23 & -0.23 & 1,52 & $2,98^{*}$ & 1,69 & $-0,59$ \\
\hline \multirow[t]{12}{*}{6} & 6.00 & 34.3 & phi0126 & 0.30 & -0.15 & 0.54 & -0.52 & $-11,13$ 。 & 0,88 & 0,88 & $-0,26$ \\
\hline & 6.02 & 14.3 & bnlg1371 & $-0.84^{*}$ & $0.74 。$ & 0.76 & 0.03 & $-12,21^{*}$ & 0,43 & 3,52 & $-1,41$ \\
\hline & 6.01 & 9.9 & phi0077 & -0.60 & 0.21 & 0.17 & -0.14 & $-14,39^{*}$ оо & $-0,37$ & 5,32 & $-0,65$ \\
\hline & 6.02 & 0.8 & umc1006 & $0.95^{\star}$ & $0.58^{*}$ & -0.37 & -0.21 & $-6,25$ & 1,53 & 0,92 & $-2,57$ \\
\hline & 6.02 & 13.1 & umc1257 & 0.61 & $0.66^{\star *}$ & -0.50 & -0.14 & $-7,08$ & 1,66 & 1,60 & $-2,64^{*}$ \\
\hline & 6.03 & 13.9 & umc1887 & -0.71 & $0.64^{* *}$ & -0.10 & 0.27 & $-3,54$ & 0,83 & 1,24 & $-1,30$ \\
\hline & 6.04 & 18.9 & umc1614 & $-1.48^{*}$ & $0.65^{\star *}$ & 0.11 & -0.11 & $-2,69$ & $-0,10$ & 3,11 & 0,36 \\
\hline & 6.05 & 22.4 & nc0013 & $-1.09^{\star}$ & 0.64 & $1.08^{*}$ & 0.56 & 3,78 & 0,56 & 2,95 & 2,12 \\
\hline & 6.06 & 21.2 & umc1520 & -1.06 & 0.03 & 0.44 & 0.25 & 2,51 & 0,38 & $-2,21$ & 0,24 \\
\hline & 6.07 & 11.5 & bnlg1759 & 0.62 & 0.26 & 0.60 & -0.07 & 1,36 & 1,82 & 1,21 & 0,86 \\
\hline & 6.07 & 2.6 & umc1653 & 1.24 & 0.41 & 0.46 & -0.02 & $2,61_{\text {o० }}$ & 0,77 & 1,20 & 2,43 \\
\hline & 6.08 & --- & umc1127 & 0.85 & 0.06 & 0.26 & -0.01 & $3,24_{000}$ & $-0,40$ & 0,49 & 1,42 \\
\hline
\end{tabular}


Tabela 17. Estimativas e significâncias dos coeficientes de regressão parciais ( $\beta^{\prime}$ s) para os caracteres posição relativa da espiga (AE/AP) e intervalo de florescimento (FM-FF)..

\begin{tabular}{|c|c|c|c|c|c|c|c|c|c|c|c|}
\hline \multirow{2}{*}{$\mathrm{C}^{\mathrm{a}}$} & \multirow{2}{*}{ Bin } & \multirow{2}{*}{$\mathrm{cM}^{\mathrm{b}}$} & \multirow{2}{*}{ Marcador } & \multicolumn{4}{|c|}{ Posição relativa da espiga (PRE) ${ }^{d}$} & \multicolumn{4}{|c|}{ Intervalo de florescimento (IF) ${ }^{\mathrm{e}}$} \\
\hline & & & & $\beta_{1}{ }^{\mathrm{C}}$ & $\beta_{2}$ & $\beta_{3}$ & $\beta_{4}$ & $\beta_{1}$ & $\beta_{2}$ & $\beta_{3}$ & $\beta_{4}$ \\
\hline \multirow[t]{9}{*}{7} & 7.00 & 34.5 & umc1426 & -0.88 & 0.60 & 0.01 & 0.06 & $6,67^{\star \star}$ & 0,28 & $-2,71$ & $-0,83$ \\
\hline & 7.01 & 7.6 & umc1632 & $-3.46^{\star}$ 。 & $0.70^{*}$ & 1.00 & 0.15 & $-7,05^{\star}$ & 1,64 & 1,81 & $-0,43$ \\
\hline & 7.01 & 0.1 & umc1409 & $-3.50^{*}$ 。 & $0.78^{*}$ & 0.58 & 0.16 & $-8,04^{*}$ & 1,98 & 1,37 & $-0,83$ \\
\hline & 7.02 & 28.3 & bnlg1094 & $-3.50^{*}$ & $0.80^{*}$ & 0.54 & 0.18 & $-7,58^{*}$ & $2,05^{\star}$ & 0,96 & $-0,99$ \\
\hline & 7.03 & 39.7 & bnlg0434 & -1.21 & 0.22 & 0.29 & -0.27 & $-3,37$ & $-3,42$ & 2,32 & 1,23 \\
\hline & 7.04 & 32.6 & dupssr13 & -0.20 & -0.50 & 0.32 & 0.02 & $-6,68^{*}$ & $-4,87^{* *}$ & 4,80 & $2,91^{*}$ \\
\hline & 7.05 & 3.2 & umc1154 & 0.47 & $1.01^{* \star}$ & 0.10 & -0.01 & $-3,19$ & 1,32 & 3,12 & $-2,45$ \\
\hline & 7.05 & 6.7 & umc1407 & 0.63 & 0.11 & -0.05 & 0.21 & $-6,58$ & 2,13 & 4,85 & $-1,67$ \\
\hline & 7.06 & --- & phi0116 & 0.77 & 0.18 & 0.54 & 0.12 & $-3,91$ & 1,42 & 4,22 & $-0,63$ \\
\hline \multirow[t]{11}{*}{8} & 8.01 & 12.1 & umc1139 & 0.28 & -0.42 & 0.31 & $0.52^{*}$ & $-10,09^{*}$ & 0,91 。 & 7,00 & $-1,85$ \\
\hline & 8.00 & 14.5 & phi420701 & 1.38 & $-0.66^{*}$ & 0.93 & 0.01 & $-9,37^{*}$ & $-0,60$ & $6,39^{*}$ & $-1,53$ \\
\hline & 8.02 & 11.9 & phi0119 & 1.09 & $-0.67^{\star *}$ & 0.68 & -0.21 & $-11,93^{*}$ & $-0,23$ & $7,32^{* * *}$ & $-0,08$ \\
\hline & 8.03 & 22.0 & umc1034 & 0.30 & -0.25 & 0.53 & -0.41 & $-5,98$ & 0,01 & 5,85 & $-0,88$ \\
\hline & 8.04 & 24.4 & bnlg1863 & 1.31 & -0.40 & 1.26 & -0.02 & $-11,24^{*}$ & 2,05 & 7,49 & $-0,05$ \\
\hline & 8.05 & 37.4 & bnlg1176 & 1.41 & -0.18 。 & $0.85^{*}$ & -0.31 & $-7,57$ 。 & 1,52 & 5,11 & $-1,55$ \\
\hline & 8.06 & 12.5 & bnlg1607 & 0.83 & 0.30 & 0.16 & 0.17 & $-2,53$ & $-1,15$ & 1,57 & 0,39 \\
\hline & 8.07 & 8.9 & bnlg1823 & 0.96 & 0.33 & 0.18 & 0.13 & $-3,22$ & $-1,99^{*}$ & $-0,88$ & $-0,59$ \\
\hline & 8.08 & 12.1 & umc1005 & 1.09 & 0.09 & 0.17 & 0.04 & 0,33 & $-2,09^{*}$ & $-1,66$ & 0,85 \\
\hline & 8.09 & 15.6 & dupssr14 & $2.40^{* *}$ & $-0.83_{0}$ & -0.15 & 0.32 & $-2,62$ & $-0,47$ & 0,56 & $-2,04$ \\
\hline & 8.09 & --- & bnlg1131 & $2.31^{\star *}$ & 0.21 & 0.16 & -0.31 & $-3,10$ & $-0,05$ & 3,76 & $-1,60$ \\
\hline \multirow[t]{10}{*}{9} & 9.02 & 2.4 & umc1170 & 0.49 & 0.01 & 0.48 & 0.00 & $-9,96$ & 1,59 & 6,46 & $-2,04$ \\
\hline & 9.02 & 11.8 & dupssr06 & 0.24 & 0.07 & 0.45 & 0.13 & $-9,85$ & 2,51 & 5,58 & $-2,11$ \\
\hline & 9.02 & 4.7 & bnlg1401 & 0.20 & 0.16 & 0.92 & 0.04 & $-12,09^{*}$ & 0,49 & 5,97 & $-2,90^{*}$ \\
\hline & 9.02 & 14.0 & umc1893 & -0.32 & 0.29 & 0.43 & 0.11 & $-12,30^{*}$ & 1,71 & 6,35 & $-2,43$ \\
\hline & 9.03 & 12.3 & bnlg0430 & -0.49 & 0.12 & 0.16 & -0.11 & $-13,87^{\star *}$ & 1,87 & 4,97 & $-2,04$ \\
\hline & 9.04 & 5.6 & umc1107 & -0.54 & 0.05 & 0.72 & -0.20 & $-7,58$ & 2,96 & $6,21^{* *}$ & $-1,52$ \\
\hline & 9.05 & 34.1 & bnlg1012 & -0.10 & 0.45 & $0.66^{\star}$ & -0.20 & $-4,63$ & 2,38 & $4,72^{*}$ & $-0,79$ \\
\hline & 9.06 & 13.8 & umc1733 & 0.32 & $-1.24^{*}$ & 1.89 & -0.11 & 7,65 & $-1,31$ & 2,01 & 0,65 \\
\hline & $9.07-08$ & 7.8 & bnlg0619 & -0.57 & -0.57 & $1.65^{\star *}$ & -0.26 & 3,74 & 1,28 & 1,74 & 0,37 \\
\hline & 9.07 & --- & bnlg0128 & -0.29 & 0.10 & $1.10^{\star}$ & 0.03 & 1,91 & 2,43 & $-0,29$ & 0,09 \\
\hline \multirow[t]{12}{*}{10} & 10.00 & 9.8 & phi0117 & -0.13 & 0.07 & 0.28 & 0.07 & $-6,65$ & $-2,17$ & 4,20 & 2,42 \\
\hline & 10.01 & 6.3 & umc1319 & -1.11 & -0.18 & 0.74 & -0.15 & $-2,67$ & $-1,28$ & 1,25 & 0,76 \\
\hline & 10.02 & 40.7 & bnlg1451 & $-0.56_{0 o}$ & 0.06 & 0.85 & -0.25 & $-2,70$ & $-1,15$ & $-0,39$ & 1,48 \\
\hline & 10.03 & 7.3 & bnlg0640 & $-1.15_{0 o}$ & -0.26 & 0.38 & 0.22 & $-2,40$ & $-0,15$ & 0,47 & 0,06 \\
\hline & 10.04 & 27.0 & bnlg1526 & $-0.09_{000}$ & -0.56 & 0.04 & 0.14 & $-0,27$ & $-1,35$ & 2,61 & 1,23 \\
\hline & 10.05 & 7.0 & umc1930 & $-1.41_{0}$ & $0.92^{* * *}$ & 0.85 & 0.08 & $-6,59$ & 0,56 & $5,70^{\star *}$ & $-0,07$ \\
\hline & 10.05 & 12.1 & umc1506 & $-2.20^{*}$ & $0.76^{* *}$ & 1.32 & 0.31 & $-7,32$ & 0,49 & $7,34^{\star *}$ & 0,30 \\
\hline & 10.07 & 0.2 & umc1196 & $-3.99^{* *}$ & 0.18 & 1.99 & 0.03 & $-2,81$ & $-0,49$ & $10,95^{*}$ & $-1,53$ \\
\hline & 10.07 & 0.1 & umc1038 & $-4.60^{\star *}$ & 0.70 & 2.07 & -0.17 & $-1,52$ & 0,59 & $10,67^{\star *}$ & $-1,59$ \\
\hline & 10.07 & 0.1 & umc2021 & $-3.87^{\star *}$ & 0.19 & 1.71 & 0.14 & 1,22 & $-0,15$ & $9,93^{*}$ & $-1,13$ \\
\hline & 10.07 & 1.4 & umc1569 & $-3.32^{*}$ & 0.13 & 1.63 & 0.16 & $-2,31$ & 0,01 & $13,71^{*}$ & $-2,22$ \\
\hline & 10.07 & --- & bnlg1839 & $-4.24^{\star * \star}$ & $0.03_{0}$ & 1.77 & 0.21 & $-3,38$ & 0,97 & $9,96^{* *}$ & $-1,77$ \\
\hline
\end{tabular}

${ }^{a}$ número do cromossomo; ${ }^{b}$ distância em centiMorgam (cM) entre locos adjacentes; ${ }^{\circ}$ Níveis de significância para os efeitos dos contrastes: ${ }^{*} \mathrm{P} \leq 0.05 ;{ }^{* *} \mathrm{P} \leq 0.01$; ${ }^{* * *} \mathrm{P} \leq 0.001$; ${ }^{* * * *} \mathrm{P} \leq 0.0001 \mathrm{e}$ ${ }^{* * * * *} P \leq 0.00001$; níveis de significância para as interações contrastes por ambientes: o $P \leq 0.05$; oo $P \leq 0.01$; $000 P \leq 0.001$; $0000 P \leq 0.0001$; ${ }^{d}$ estimativas dos efeitos de posição

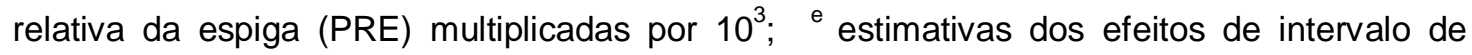
florescimento (IF) multiplicadas por $10^{2}$. 
Tabela 18. Estimativas e significâncias dos coeficientes de regressão parciais ( $\beta^{\prime}$ s) para os caracteres florescimento feminino (dias) e florescimento masculino (dias).

\begin{tabular}{|c|c|c|c|c|c|c|c|c|c|c|c|}
\hline \multirow{2}{*}{$\mathrm{C}^{\mathrm{a}}$} & \multirow{2}{*}{ Bin } & \multirow{2}{*}{\multicolumn{2}{|c|}{$\mathrm{cM}^{\mathrm{b}}$ Marcador }} & \multicolumn{4}{|c|}{ Florescimento feminino $(F F)^{d}$} & \multicolumn{4}{|c|}{ 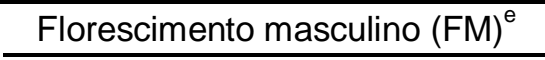 } \\
\hline & & & & $\beta_{1}{ }^{c}$ & $\beta_{2}$ & $\beta_{3}$ & $\beta_{4}$ & $\beta_{1}$ & $\beta_{2}$ & $\beta_{3}$ & $\beta_{4}$ \\
\hline \multirow[t]{19}{*}{1} & 1.01 & 10.7 & umc1177 & $-17.11^{* *}$ & $2.86^{*}$ & $-12.17^{* *}$ & -0.62 & $-16.60^{* * *}$ & $4.01^{*}$ & $-12.65^{\star *}$ & -0.89 \\
\hline & 1.01 & 0.9 & bnlg1014 & $-16.58^{*}$ & 0.10 & $-13.19^{* *}$ & 1.72 & $-15.85^{\star *}$ & -0.14 & $-12.15^{\star}$ & 2.12 \\
\hline & 1.00 & 19.8 & umc1106 & $-17.02^{*}$ & -1.35 & $-18.07^{* *}$ & 1.17 & $-17.89^{* *}$ & -1.01 & $-15.84^{* *}$ & 1.33 \\
\hline & 1.02 & 11.4 & bnlg1627 & 4.34 & -4.96 & $-12.73^{\star *}$ & 3.81 & 6.32 & -3.98 & $-11.55^{\star *}$ & $2.22^{*}$ \\
\hline & 1.02 & 5.7 & bnlg1083 & $9.96^{*}$ & -3.05 & $-10.42^{*}$ & -0.17 & 11.37 & $-3.57^{*}$ & $-11.25^{\star \star}$ & 0.57 \\
\hline & 1.03 & 9.9 & umc1073 & $15.64^{*}$ & -1.56 & $-11.38^{*}$ & -4.04 & $17.24^{*}$ & -3.73 & $-11.59^{* *}$ & -2.19 \\
\hline & 1.03 & 8.7 & umc1021 & $28.56^{\star *}$ & -3.73 & $-14.49^{\star}$ & -3.25 & $27.43^{*}$ & $-3.97^{*}$ & $-14.33^{\star \star}$ & -0.76 \\
\hline & 1.04 & 21.9 & bnlg2238 & 8.91 & -5.92 & $-9.70^{*}$ & $3.03^{*}$ & 14.91 。 & -3.98 & $-11.15^{\star \star}$ & 2.22 \\
\hline & 1.05 & 13.1 & umc2025 & 5.13 & -1.50 & -9.04 & $5.68^{*}$ & 9.01 & -1.20 & $-11.97^{* *}$ & $4.40^{* *}$ \\
\hline & 1.05 & 10.7 & umc1601 & 4.61 & 1.64 & -4.39 & 4.63 & 4.09 & 0.69 & -7.10 & $4.22^{*}$ \\
\hline & 1.06 & 5.7 & umc1508 & $11.19^{*}$ & $4.13^{*}$ & -4.73 & 2.51 & 7.60 & 2.77 & $-5.87^{\star *}$ & 2.71 \\
\hline & 1.06 & 6.8 & bnlg1598 & $7.75^{\star *}$ & $5.21^{* *}$ & -2.74 & 0.65 & $5.26^{*}$ & 4.37 & -2.26 & 0.95 \\
\hline & 1.06 & 25.6 & umc1035 & 7.93 & $4.90^{*}$ & $-5.68^{*}$ & -0.28 & $7.29^{*}$ & $5.33^{\star \star \star}$ & $-7.52^{*}$ & -0.71 \\
\hline & 1.07 & 15.9 & bnlg0615 & $-21.22^{\star *}$ & $4.85^{\star *}$ & $-13.85^{\star *}$ & -1.03 & $-19.12^{*}$ & $4.13^{*}$ & $-14.33^{* *}$ & -0.22 \\
\hline & 1.10 & 24.1 & umc1431 & -0.48 & $-5.81^{*}$ & -2.24 & -0.28 & -5.16 & $-5.66^{*}$ & 0.44 & 0.24 \\
\hline & 1.08 & 24.2 & phi0037 & $-15.03^{*}$ & $-4.83^{* *}$ & $-4.73^{*}$ & -1.76 & $-15.24^{\star *}$ & $-3.43^{* *}$ & -5.37 & -1.17 \\
\hline & 1.11 & 11.6 & phi0120 & -1.200 & $-6.68^{* *}$ & -0.97 & 2.32 & -3.61 & $-6.74^{\star * *}$ & -0.45 & 2.15 \\
\hline & 1.11 & 17.6 & umc1630 & -4.14 & $-3.69^{*}$ & 0.92 & 1.16 & -5.51 & $-4.59^{*}$ & -0.86 & 1.11 \\
\hline & 1.12 & --- & umc1605 & $-14.83^{*}$ & 0.44 & -1.38 & -1.88 & $-18.13^{*}$ & -2.94 & -1.24 & 0.33 \\
\hline \multirow[t]{19}{*}{2} & 2.01 & 4.6 & umc1165 & 0.93 & 1.10 & -8.17 & -2.93 & -2.23 & 0.96 & -2.25 & -2.61 \\
\hline & 2.01 & 1.3 & bnlg1338 & -4.40 & 2.77 & $-13.38^{*}$ & -2.29 & -4.93 & 0.97 & -6.85 & -1.23 \\
\hline & 2.01 & 1.5 & umc1227 & -6.73 & $4.44^{*}$ & $-13.02^{*}$ & -2.40 & -6.69 & 2.15 & -6.57 & -0.71 \\
\hline & 2.02 & 2.8 & bnlg1017 & -3.67 & $6.43^{* *}$ & $-11.72^{*}$ & $-2.91^{*}$ & -4.89 & 3.44 & -7.33 & -1.59 \\
\hline & 2.02 & 12.9 & umc1265 & -7.03 & $8.42^{* \star \star *}$ & $-12.52^{*}$ & -2.08 & $-9.08^{*}$ & $5.96^{* *}$ & -8.76 & -0.41 \\
\hline & 2.02 & 8.6 & umc1934 & $9.90^{* *}$ & $5.96^{*}$ & -13.60 & -3.15 & -0.08 & $4.45^{\star}$ & -6.56 & -3.08 \\
\hline & 2.02 & 4.0 & bnlg0125 & 6.80 & 3.80 & -11.04 & $-4.83^{*}$ & 0.72 & 2.38 & -2.50 & -4.14 \\
\hline & 2.03 & 0.9 & umc1845 & $15.87^{\star *}$ & 2.17 & $-17.65^{\star}$ & 0.28 & 6.00 & 1.97 & -7.75 & 1.21 \\
\hline & 2.03 & 2.5 & umc1776 & 9.54 & -3.48 & $-21.25^{\star}$ & -0.04 & 4.10 & -0.45 & $-11.53^{*}$ & -0.18 \\
\hline & 2.03 & 7.1 & bnlg2248 & $14.23^{*}$ & $6.64^{* *}$ & $-20.44^{*}$ & -0.68 & 3.98 & $5.76^{*}$ & -9.88 & 0.00 \\
\hline & 2.03 & 32.2 & bnlg0381 & $6.70^{*}$ & -0.62 & $-16.81^{*}$ & $-3.53^{*}$ & 2.40 & -1.42 & -7.44 & -2.77 \\
\hline & 2.04 & 10.1 & bnlg0166 & -1.90 & $-8.37^{* *}$ & $-14.87^{*}$ & 3.00 & -3.78 & $-6.09^{* *}$ & $-9.89^{*}$ & 0.92 \\
\hline & 2.05 & 19.5 & dupssr21 & -4.73 & $-3.37^{* * *}$ & $-16.75^{\star}$ & -2.30 & -6.69 & -2.62 & $-14.39^{*}$ & $-3.68^{*}$ \\
\hline & 2.06 & 78.3 & bnlg1396 & $-13.66^{*}$ & $3.45^{\star}$ & -5.44 & -1.61 & $-8.38^{*}$ & 2.22 & -6.46 & -1.14 \\
\hline & 2.07 & 6.3 & umc1560 & $24.70^{* *}$ & -0.06 & -4.25 & 0.11 & $19.24^{* *}$ & 0.98 & -1.65 & 0.80 \\
\hline & 2.08 & 6.5 & umc1464 & $33.45^{\star *}$ & $7.61^{* *}$ & -3.19 & $-3.12^{* * *}$ & $31.63^{\star *}$ & $6.79^{*}$ & 1.60 & $-2.56^{\star}$ \\
\hline & 2.08 & 6.9 & umc1633 & $22.79^{\star *}$ & 4.34 & -5.94 & $-2.99^{*}$ & $23.14^{\star *}$ & 4.62 & -2.59 & $-2.61^{*}$ \\
\hline & 2.09 & 4.9 & umc1230 & $19.44^{* *}$ & 3.99 & -4.27 & $-5.07^{* *}$ & $21.80^{* * *}$ & 3.33 & -2.82 & -2.14 \\
\hline & 2.09 & --- & bnlg1520 & $13.96^{* *}$ & 5.88 & -4.16 & $-4.05^{\star}$ & $17.58^{* * * * *}$ & $6.33^{*}$ & -2.82 & $-1.72^{\star}$ \\
\hline \multirow[t]{13}{*}{3} & 3.01 & 17.4 & umc1394 & 7.82 & $7.47^{*}$ & -3.12 & 0.10 & 7.67 & $7.28^{*}$ & -1.81 & -1.42 \\
\hline & 3.03 & 27.7 & bnlg1144 & $18.53^{*}$ & 2.20 & $-9.95^{\star *}$ & -0.25 & $14.17^{* *}$ & 2.00 & $-8.21^{*}$ & $-1.86^{\star}$ \\
\hline & 3.04 & 7.8 & bnlg1452 & $18.69^{*}$ & -0.80 & -10.68 & -1.73 & $14.52^{* *}$ & -2.67 & $-9.03^{*}$ & -0.52 \\
\hline & 3.04 & 12.1 & bnlg602 & 13.67 & -1.09 & $-10.99^{*}$ & -1.73 & $10.39^{*}$ & -1.53 & $-9.27^{*}$ & -1.40 \\
\hline & 3.05 & 1.8 & bnlg0420 & $25.39^{*}$ & -2.65 & -5.71 & -3.30 & $23.15^{\star *}$ & -4.23 & -4.70 & -1.24 \\
\hline & 3.05 & 34.1 & $\mathrm{mmc} 0022$ & $26.45^{*}$ & -3.73 & -7.59 & -3.86 & $25.28^{* *}$ & $-5.63^{*}$ & -5.76 & -2.19 \\
\hline & 3.06 & 28.6 & bnlg1798 & $23.40^{*}$ & -3.76 & -0.85 & $-5.49 * *$ & $24.22^{\star *}$ & -6.37 & -3.62 & $-4.23^{*}$ \\
\hline & 3.07 & 3.3 & umc1690 & 5.59 & $-7.53^{\star *}$ & 3.04 & $4.97^{*}$ & -0.81 & $-6.22^{* * \star \star *}$ & $2.55^{* *}$ & 2.96 \\
\hline & 3.07 & 16.0 & umc1659 & 16.31 & $-7.06^{\star *}$ & 1.86 & 2.08 & 10.08 & $-5.96^{\star * *}$ & 2.20 & 1.15 \\
\hline & 3.08 & 14.1 & umc1320 & $15.91^{*}$ & $-4.08^{*}$ & -4.49 & -0.74 & 8.88 & -2.09 & -3.12 & -2.01 \\
\hline & 3.09 & 2.9 & bnlg1536 & 5.52 & -2.34 & -1.03 & -2.38 & 2.93 & -1.49 & 0.81 & -2.27 \\
\hline & 3.09 & 26.7 & bnlg1754 & -4.30 & -5.01 & 3.54 & -0.74 & -3.93 & -1.83 & 5.25 & -3.05 \\
\hline & 3.10 & --- & bnlg1098 & $8.80^{\star}$ & $-2.72^{* *}$ & -3.93 & -3.00 & 9.71 & 0.56 & -1.58 & -2.08 \\
\hline
\end{tabular}


Tabela 18. Estimativas e significâncias dos coeficientes de regressão parciais ( $\beta^{\prime}$ s) para os caracteres florescimento feminino (dias) e florescimento masculino (dias).

\begin{tabular}{|c|c|c|c|c|c|c|c|c|c|c|c|}
\hline \multirow{2}{*}{$\mathrm{C}^{\mathrm{a}}$} & \multirow{2}{*}{ Bin } & \multirow{2}{*}{$\mathrm{cM}^{\mathrm{b}}$} & \multirow{2}{*}{ Marcador } & \multicolumn{4}{|c|}{ Florescimento feminino $(F F)^{d}$} & \multicolumn{4}{|c|}{ Florescimento masculino $(\mathrm{FM})^{\mathrm{e}}$} \\
\hline & & & & $\beta_{1}{ }^{\mathrm{c}}$ & $\beta_{2}$ & $\beta_{3}$ & $\beta_{4}$ & $\beta_{1}$ & $\beta_{2}$ & $\beta_{3}$ & $\beta_{4}$ \\
\hline \multirow[t]{19}{*}{4} & 4.01 & 55.7 & umc1276 & $17.93^{*}$ & $8.94^{* *}$ & $-15.77^{\star \star * *}$ & -3.19 & 9.00 & $6.70^{* *}$ & $-8.08^{* *}$ & -1.24 \\
\hline & 4.04 & 3.4 & umc1652 & $-14.26^{*}$ & 0.75 & -7.81 & 1.71 & -7.48 & 1.47 & $-7.74^{*}$ & 0.68 \\
\hline & 4.05 & 0.1 & phi0026 & $-14.47^{*}$ & -4.88 & -3.82 & 3.17 & -6.89 & -3.12 & -1.91 & 2.03 \\
\hline & 4.05 & 1.7 & umc1088 & $-14.67^{*}$ & -4.70 & -6.09 & 2.11 & -8.44 & -3.11 & -4.82 & 0.63 \\
\hline & 4.06 & 35.6 & bnlg0252 & $-15.35^{*}$ & $-5.73^{*}$ & -6.08 & 0.41 & -9.62 & $-3.82^{*}$ & -5.15 & 0.04 \\
\hline & 4.07 & 5.1 & bnlg2291 & $-10.42^{*}$ & -1.86 & 0.02 & $3.93^{* *}$ & -3.49 & -1.68 & -0.37 & $3.16^{* *}$ \\
\hline & 4.07 & 18.0 & dupssr34 & -7.26 & $-5.10^{*}$ & 1.45 & 1.41 & -1.83 & $-3.64^{*}$ & 1.22 & 0.78 \\
\hline & 4.08 & 2.0 & bnlg2244 & -10.19 & 1.27 & $-7.61^{*}$ & $3.80^{*}$ & -3.85 & $3.91^{*}$ & $-7.82^{*}$ & 1.22 \\
\hline & 4.08 & 4.7 & bnlg2162 & -7.99 & -1.41 & -1.95 & $6.60^{* *}$ & -2.07 & 1.91 & -2.92 & $4.20^{*}$ \\
\hline & 4.08 & 4.6 & umc1086 & -4.52 & $-6.94^{\star *}$ & $-6.44^{*}$ & 1.22 & -1.10 & $-4.18^{*}$ & $-7.69^{* *}$ & -0.17 \\
\hline & 4.08 & 11.5 & umc1051 & -0.19 & -1.57 & -2.29 & $2.65^{\star}$ & 6.22 & 0.79 & $-4.76^{*}$ & 1.02 \\
\hline & 4.09 & 15.6 & umc1989 & 0.70 & 2.45 & -1.10 & -2.19 & 5.91 & $4.92^{*}$ & -2.69 & $-3.37^{* *}$ \\
\hline & 4.09 & 0.6 & phi314704 & -0.22 & 2.06 & 3.32 & -0.67 & -1.45 & 2.37 & 1.68 & -0.75 \\
\hline & 4.11 & 0.2 & bnlg0589 & $-4.13^{*}$ & 1.71 & 1.29 & -0.13 & $-7.73^{\star \star}$ & 0.81 & 0.46 & -0.43 \\
\hline & 4.10 & 0.2 & umc1503 & -1.66 & 2.56 & 0.90 & -1.83 & $-2.83^{\star *}$ & 2.67 & -0.67 & $-1.84^{*}$ \\
\hline & 4.10 & 5.9 & umc1532 & -2.22 & 3.50 & 1.35 & -1.72 & $-3.90^{* *}$ & $3.57^{*}$ & -0.39 & $-1.76^{*}$ \\
\hline & 4.10 & 6.3 & umc1109 & -3.70 & -0.51 & 1.11 & 0.60 & -5.25 & 1.07 & 0.64 & 0.18 \\
\hline & 4.11 & 6.2 & bnlg1337 & 1.02 & -2.08 & -2.12 & -0.79 & -0.31 & -1.67 & -2.37 & -0.09 \\
\hline & 4.11 & --- & umc1197 & 0.05 & -4.59 & -4.43 & 1.45 & -1.96 & -3.10 & -2.69 & 0.33 \\
\hline \multirow[t]{16}{*}{5} & 5.00 & 40.7 & bnlg1006 & $-14.75^{*}$ & $-5.91^{*}$ & -6.72 & 2.79 & $-17.77^{*}$ & -2.93 & -6.84 & 1.84 \\
\hline & 5.02 & 8.3 & umc1587 & -9.73 & $5.22^{* *}$ & $-13.76^{* *}$ & 1.78 & -10.02 & 2.34 & $-9.63^{* *}$ & 0.60 \\
\hline & 5.03-04 & 5.3 & phi0113 & $-15.70_{0}$ & $8.17^{\star \star}$ & $-13.09^{* *}$ & 1.04 & -12.68 o & $5.56^{*}$ & $-9.39^{* *}$ & 1.57 \\
\hline & 5.03 & 16.1 & bnlg1879 & -14.85 & $6.45^{\star *}$ & $-14.85^{\star *}$ & 1.66 & $-14.46^{*}$ & $4.89^{\star}$ & $-11.13^{\star *}$ & 0.82 \\
\hline & 5.03 & 14.1 & umc1056 & $-19.81^{*}$ & 0.28 & -10.19 & 0.82 & $-15.38^{*}$ & -0.45 & $-13.31^{* *}$ & -0.07 \\
\hline & 5.03 & 9.7 & bnlg1902 & $-16.47^{\star *}$ & 2.14 & $-14.99^{*}$ & 2.13 & $-11.42^{\star *}$ & 1.56 & $-19.28^{* *}$ & 1.18 \\
\hline & 5.04 & 17.7 & dupssr10 & -7.12 & 4.42 & $-20.30^{* *}$ & 3.37 & -8.90 & 3.06 & $-20.17^{\star *}$ & 2.61 \\
\hline & 5.04 & 3.8 & umc1221 & $-14.59^{*}$ & 1.08 & -10.97 & $3.98^{*}$ & $-9.79^{*}$ & 1.67 & $-13.80^{*}$ & $3.16^{*}$ \\
\hline & 5.05 & 23.5 & $\mathrm{mmc} 0081$ & $-14.10^{*}$ & -0.36 & -10.59 & $4.54^{* *}$ & $-9.84^{*}$ & -0.59 & $-12.95^{\star}$ & $3.93^{* *}$ \\
\hline & 5.06 & 2.1 & umc1019 & $-27.55^{\star \star}$ & -5.21 & -5.55 & $4.10^{*}$ & $-21.25^{\star *}$ & -1.97 & -5.58 & 3.03 \\
\hline & 5.06 & 2.3 & $\mathrm{mmc} 0481$ & $-27.45^{\star * *}$ & -3.73 & -7.92 & 3.61 & $-22.24^{\star * *}$ & -0.95 & -7.34 & 2.67 \\
\hline & $5.05-06$ & 1.6 & bnlg278 & $-25.93^{\star *}$ & -4.54 & -5.84 & 4.13 & $-22.16^{\star * *}$ & -2.93 & -6.10 & $3.63^{*}$ \\
\hline & 5.06 & 0.1 & umc1680 & $-25.27^{\star \star *}$ & $-5.44^{*}$ & -6.33 & 3.86 & $-21.49^{* * *}$ & -3.07 & -5.46 & 2.36 \\
\hline & 5.06 & 21.9 & umc1524 & $-25.04^{\star \star \star}$ & -5.19 & -8.27 & 3.91 & $-21.64^{* * *}$ & -2.86 & -7.16 & 2.40 \\
\hline & 5.07 & 32.3 & phi0128 & -7.34 & 2.69 & -6.05 & 2.37 & -4.20 & $4.11^{*}$ & -5.03 & 1.65 \\
\hline & 5.09 & --- & umc1153 & 5.34 & 0.23 & 2.47 & 1.50 & 6.85 & $3.21^{* *}$ & $4.16^{*}$ & 0.91 \\
\hline \multirow[t]{12}{*}{6} & 6.00 & 34.3 & phi0126 & $17.38^{*}$ & $-4.55^{\star \star}$ & -0.20 & 3.81 & 6.25 & $-3.67^{\star * *}$ & 0.67 & $3.55^{\star}$ \\
\hline & 6.02 & 14.3 & bnlg1371 & $14.57^{*}$ & -2.11 & -0.20 & 2.44 & 2.36 & -1.68 & 3.32 & 1.04 \\
\hline & 6.01 & 9.9 & phi0077 & $24.26^{\star *}$ & 0.29 & $-6.93^{*}$ & 1.67 & $9.86^{* *}$ & -0.08 & -1.62 & 1.02 \\
\hline & 6.02 & 0.8 & umc1006 & $14.40^{*}$ & $-5.64^{*}$ & 0.52 & 3.66 & $8.16^{*}$ & -4.12 & 1.44 & 1.09 \\
\hline & 6.02 & 13.1 & umc1257 & 7.67 & $-5.80^{*}$ & 0.05 & 3.72 & 0.59 & -4.14 & 1.65 & 1.08 \\
\hline & 6.03 & 13.9 & umc1887 & 0.54 & -0.27 & $-13.26^{*}$ & 2.27 & -3.00 & 0.56 & $-12.01^{\star \star *}$ & 0.98 \\
\hline & 6.04 & 18.9 & umc1614 & 1.48 & 2.51 & $-15.47^{\star}$ & -1.74 & -1.21 & 2.41 & $-12.36^{* *}$ & -1.38 \\
\hline & 6.05 & 22.4 & nc0013 & 0.96 & 0.41 & $-13.85^{*}$ & -1.12 & 4.75 & 0.97 & $-10.90^{*}$ & 1.00 \\
\hline & 6.06 & 21.2 & umc1520 & 1.43 & -1.62 & $-9.12^{*}$ & -0.67 & 3.94 & -1.24 & $-11.33^{*}$ & -0.43 \\
\hline & 6.07 & 11.5 & bnlg1759 & $8.26^{*}$ & -2.11 & -5.13 & 1.94 & 9.62 & -0.29 & -3.92 & $2.80^{*}$ \\
\hline & 6.07 & 2.6 & umc1653 & -2.60 & -2.17 & $-12.38^{* *}$ & -1.86 & 0.00 & -1.40 & -11.18 & 0.57 \\
\hline & 6.08 & --- & umc1127 & -0.36 & -2.02 & $-10.07^{\star *}$ & -0.51 & 2.87 & -2.41 & -9.58 & 0.91 \\
\hline
\end{tabular}


Tabela 18. Estimativas e significâncias dos coeficientes de regressão parciais ( $\beta^{\prime}$ s) para os caracteres florescimento feminino (dias) e florescimento masculino (dias).

\begin{tabular}{|c|c|c|c|c|c|c|c|c|c|c|c|}
\hline \multirow{2}{*}{$\mathrm{C}^{\mathrm{a}}$} & \multirow{2}{*}{ Bin } & \multirow{2}{*}{\multicolumn{2}{|c|}{$\mathrm{cM}^{\mathrm{b}}$ Marcador }} & \multicolumn{4}{|c|}{ Florescimento feminino $(F F)^{d}$} & \multicolumn{4}{|c|}{ Florescimento masculino $(\mathrm{FM})^{\mathrm{e}}$} \\
\hline & & & & $\beta_{1}{ }^{\mathrm{c}}$ & $\beta_{2}$ & $\beta_{3}$ & $\beta_{4}$ & $\beta_{1}$ & $\beta_{2}$ & $\beta_{3}$ & $\beta_{4}$ \\
\hline \multirow[t]{9}{*}{7} & 7.00 & 34.5 & umc1426 & $-22.80^{* *}$ & 2.92 & -7.26 & $-3.23^{*}$ & $-16.13^{* *}$ & 3.20 & $-9.98^{*}$ & $-4.06^{* *}$ \\
\hline & 7.01 & 7.6 & umc1632 & -2.22 & $3.52^{*}$ & $-13.73^{*}$ & 3.28 & -9.27 & $5.15^{\star \star \star *}$ & $-11.93^{* *}$ & 2.85 \\
\hline & 7.01 & 0.1 & umc 1409 & 3.06 & 0.70 & $-13.19^{* *}$ & $5.74^{* *}$ & -4.98 & $2.69^{*}$ & $-11.82^{* *}$ & $4.92^{*}$ \\
\hline & 7.02 & 28.3 & bnlg1094 & -0.37 & 1.31 & $-12.21^{\star}$ & $5.73^{\star *}$ & -7.95 & $3.35^{*}$ & $-11.25^{\star *}$ & $4.74^{*}$ \\
\hline & 7.03 & 39.7 & bnlg0434 & -1.95 & 2.14 & $-14.03^{* *}$ & -0.09 & -5.32 & -1.27 & $-11.72^{*}$ & 1.15 \\
\hline & 7.04 & 32.6 & dupssr13 & $10.46^{*}$ & $12.61^{* *}$ & -9.63 & 1.82 & 3.78 & $7.74^{*}$ & -4.83 & $4.73^{*}$ \\
\hline & 7.05 & 3.2 & umc 1154 & $23.36^{*}$ & -2.74 & -2.14 & 3.95 & $20.17^{* *}$ & -1.42 & 0.98 & 1.51 \\
\hline & 7.05 & 6.7 & umc1407 & $22.88^{* *}$ & -4.59 & -6.99 & 1.12 & $16.31^{* * *}$ & -2.46 & -2.15 & -0.56 \\
\hline & 7.06 & -- & phi0116 & $23.11^{* *}$ & $-6.66^{*}$ & -4.13 & 0.30 & $19.20^{* *}$ & $-5.23^{*}$ & 0.09 & -0.33 \\
\hline \multirow[t]{11}{*}{8} & 8.01 & 12.1 & umc1139 & $8.51^{*}$ & -2.58 & $-8.91^{*}$ & 0.42 & -1.58 & -1.67 & -1.91 & -1.43 \\
\hline & 8.00 & 14.5 & phi420701 & $8.60^{*}$ & 0.00 & -7.92 & 0.86 & -0.77 & -0.60 & -1.53 & -0.66 \\
\hline & 8.02 & 11.9 & phi0119 & $8.21^{*}$ & $-3.41^{*}$ & $-7.61^{*}$ & 0.26 & -3.73 & -3.64 & -0.29 & 0.18 \\
\hline & 8.03 & 22.0 & umc1034 & 4.74 & -3.47 & -4.74 & 3.98 & -1.24 & -3.46 & 1.11 & 3.10 \\
\hline & 8.04 & 24.4 & bnlg1863 & 16.10 & -3.46 & -8.41 & 1.04 & 4.86 & -1.41 & -0.92 & 0.98 \\
\hline & 8.05 & 37.4 & bnlg1176 & -7.94 。 & -2.82 & 0.33 & 0.86 & -15.51 。 & -1.30 & 5.44 & -0.69 \\
\hline & 8.06 & 12.5 & bnlg1607 & $-21.93^{*}$ & 1.59 & -2.52 & -1.24 & $-24.46^{*}$ & 0.44 & -0.95 & -0.85 \\
\hline & 8.07 & 8.9 & bnlg1823 & -10.99 & -1.31 & -5.11 & -0.53 & $-14.21^{*}$ & $-3.30^{* * *}$ & -5.99 & -1.13 \\
\hline & 8.08 & 12.1 & umc 1005 & $-21.61^{* *}$ & 0.80 & -1.52 & -1.93 & $-21.28^{* *}$ & -1.29 & -3.18 & -1.08 \\
\hline & 8.09 & 15.6 & dupssr14 & $-16.31^{*}$ & $7.73^{* *}$ & 3.20 & $4.99^{* *}$ & $-18.93^{* *}$ & $7.26^{*}$ & 3.76 & $2.95^{\star}$ \\
\hline & 8.09 & -- & bnlg1131 & -3.14 & 2.26 & 1.20 & 0.77 & -6.24 & 2.20 & 4.97 & -0.83 \\
\hline \multirow[t]{10}{*}{9} & 9.02 & 2.4 & umc1170 & $23.33^{*}$ & -4.07 & -1.44 & 2.86 & 13.36 & -2.48 & 5.02 & 0.82 \\
\hline & 9.02 & 11.8 & dupssr06 & $25.33^{*}$ & $-6.49^{*}$ & 0.97 & 1.48 & $15.48^{*}$ & -3.98 & $6.55^{*}$ & -0.63 \\
\hline & 9.02 & 4.7 & bnlg1401 & $37.48^{* * *}$ & -0.51 & -1.93 & $4.22^{* *}$ & $25.39^{* * *}$ & -0.02 & 4.03 & 1.32 \\
\hline & 9.02 & 14.0 & umc1893 & $37.00^{* * *}$ & -3.40 & -0.04 & $4.40^{*}$ & $24.70^{\star * *}$ & -1.69 & 6.30 & 1.97 \\
\hline & 9.03 & 12.3 & bnlg0430 & $39.05^{\star \star *}$ & -0.24 & $3.70^{*}$ & 2.67 & $25.18^{* *}$ & 1.63 & $8.67^{*}$ & 0.62 \\
\hline & 9.04 & 5.6 & umc1107 & $29.64^{* *}$ & -1.95 & -3.28 & 0.57 & $22.07^{\star *}$ & 1.00 & 2.92 & -0.96 \\
\hline & 9.05 & 34.1 & bnlg1012 & $18.06^{*}$ & -5.97 & 0.25 & 2.27 & $13.43^{*}$ & $-3.59^{*}$ & 4.96 & 1.48 \\
\hline & 9.06 & 13.8 & umc1733 & -1.34 & $5.21^{*}$ & -2.28 & -1.83 & 6.31 & 3.90 & -0.27 & -1.18 \\
\hline & $9.07-08$ & 7.8 & bnlg0619 & -4.70 & 0.29 & -4.32 & -0.03 & -0.96 & 1.57 & -2.58 & 0.34 \\
\hline & 9.07 & --- & bnlg0128 & -2.47 & 0.60 & 3.18 & -0.94 & -0.56 & $3.03^{*}$ & 2.89 & -0.84 \\
\hline \multirow[t]{12}{*}{10} & 10.00 & 9.8 & phi0117 & $11.17^{* *}$ & 3.24 & $-6.02^{*}$ & -2.00 & $4.53^{*}$ & 1.07 & -1.82 & 0.42 \\
\hline & 10.01 & 6.3 & umc1319 & 10.46 & 6.44 & -8.82 & 0.04 & 7.80 & 5.17 & -7.57 & 0.79 \\
\hline & 10.02 & 40.7 & bnlg1451 & $11.62^{*}$ & $6.90^{*}$ & -4.20 & 1.35 & 8.92 & $5.74^{*}$ & -4.59 & 2.84 \\
\hline & 10.03 & 7.3 & bnlg0640 & 2.98 & 1.59 & -15.54 & -0.64 & 0.57 & 1.44 & $-15.07^{* *}$ & -0.58 \\
\hline & 10.04 & 27.0 & bnlg1526 & $14.59^{*}$ & 3.17 & -13.57 & -1.37 & $14.32^{* *}$ & 1.82 & $-10.96^{\star}$ & -0.15 \\
\hline & 10.05 & 7.0 & umc1930 & $34.06^{* *}$ & 0.15 & $-19.70^{\star *}$ & 0.34 & $27.47^{\star * *}$ & 0.71 & $-14.01^{*}$ & 0.27 \\
\hline & 10.05 & 12.1 & umc1506 & $36.86^{* * *}$ & 1.47 & $-25.62^{*}$ & 0.46 & $29.54^{* \star *}$ & 1.96 & $-18.29^{*}$ & 0.76 \\
\hline & 10.07 & 0.2 & umc1196 & $40.45^{\star *}$ & -1.51 & $-38.06^{\star * *}$ & 0.18 & $37.63^{* *}$ & -2.00 & $-27.11^{\star *}$ & -1.35 \\
\hline & 10.07 & 0.1 & umc1038 & $44.44^{* *}$ & -1.81 & $-36.77^{\star *}$ & 0.75 & $42.91^{* * *}$ & -1.22 & $-26.10^{* *}$ & -0.84 \\
\hline & 10.07 & 0.1 & umc2021 & $33.15^{\star *}$ & -2.30 & $-35.93^{\star *}$ & -1.01 & $34.38^{\star *}$ & -2.45 & $-26.01^{* *}$ & -2.14 \\
\hline & 10.07 & 1.4 & umc1569 & $44.64^{* *}$ & 1.07 & $-40.43^{\star *}$ & -1.08 & $42.33^{\star * *}$ & 1.08 & $-26.72^{* *}$ & -3.30 \\
\hline & 10.07 & --- & bnlg1839 & $33.41^{\star *}$ & -2.85 & $-30.25^{\star \star}$ & 2.06 & $30.03^{* *}$ & -1.88 & $-20.28^{\star *}$ & 0.29 \\
\hline
\end{tabular}

${ }^{a}$ número do cromossomo; ${ }^{b}$ distância em centiMorgam (cM) entre locos adjacentes; ${ }^{c}$ Níveis de significância para os efeitos dos contrastes: * $\mathrm{P} \leq 0.05$; ${ }^{* *} \mathrm{P} \leq 0.01 ;{ }^{* *} \mathrm{P} \leq 0.001 ;{ }^{* * *} \mathrm{P} \leq 0.0001$ $e^{* * * * *} P \leq 0.00001$; níveis de significância para as interações contrastes por ambientes: 0 $\mathrm{P} \leq 0.05 ; \quad$ estimativas dos efeitos de florescimento feminino (FF) multiplicadas por $10^{2}$; estimativas dos efeitos de florescimento masculino (FM) multiplicadas por $10^{2}$. 
Tabela 19. Estimativas e significâncias dos coeficientes de regressão parciais ( $\beta^{\prime} \mathbf{s}$ ) para os caracteres número de folhas acima da primeira espiga (folhas planta $^{-1}$ ) e teor de umidade nos grãos (\%).

\begin{tabular}{|c|c|c|c|c|c|c|c|c|c|c|c|}
\hline \multirow{2}{*}{\multicolumn{2}{|c|}{$C^{a} \operatorname{Bin}$}} & \multirow{2}{*}{$\mathrm{cM}^{\mathrm{b}}$} & \multirow{2}{*}{ Marcador } & \multicolumn{4}{|c|}{ Número de folhas $(\mathrm{NF})^{\mathrm{d}}$} & \multicolumn{4}{|c|}{ Umidade dos grãos (UM) $^{\mathrm{e}}$} \\
\hline & & & & $\beta_{1}{ }^{c}$ & $\beta_{2}$ & $\beta_{3}$ & $\beta_{4}$ & $\beta_{1}$ & $\beta_{2}$ & $\beta_{3}$ & $\beta_{4}$ \\
\hline \multirow[t]{19}{*}{1} & 1.01 & 10.7 & umc1177 & -1.34 & 0.03 & 1.31 & 0.04 & 2.78 & -1.15 & 0.53 & -0.26 \\
\hline & 1.01 & 0.9 & bnlg1014 & -1.65 & -0.67 & $1.47^{\star}$ & -0.37 & 3.66 & -0.08 & -0.43 & -0.13 \\
\hline & 1.00 & 19.8 & umc1106 & -2.10 & $-1.13^{* *}$ & $1.69^{*}$ & -0.45 & $4.22^{*}$ & -0.07 & 0.27 & -0.18 \\
\hline & 1.02 & 11.4 & bnlg1627 & $3.43^{* *}$ & -0.22 & $1.72^{*}$ & -0.49 & 2.59 & 0.71 & 0.45 & -0.61 \\
\hline & 1.02 & 5.7 & bnlg1083 & $3.58^{* *}$ & -0.73 & $2.21^{*}$ & -0.37 & 2.36 & 0.33 & 0.46 & -0.31 \\
\hline & 1.03 & 9.9 & umc1073 & $3.27^{* *}$ & $-0.83^{*}$ & 2.71 ** & -0.26 & 0.33 & -0.28 & -0.07 & -0.32 \\
\hline & 1.03 & 8.7 & umc1021 & $2.25^{\star}$ & $-1.51^{*}$ & $4.53^{\text {** }}$ & -0.15 & 2.00 & -0.27 。 & 0.38 & -0.42 \\
\hline & 1.04 & 21.9 & bnlg2238 & -0.55 & -0.57 & 1.30 & 0.61 & 0.43 & 0.27 & 0.96 & 0.06 \\
\hline & 1.05 & 13.1 & umc2025 & $-7.06^{\star * *}$ & -0.46 & $1.61^{*}$ & 0.30 & -4.09 & 0.26 & 0.62 & -0.06 \\
\hline & 1.05 & 10.7 & umc1601 & $-8.29^{\star \star *}$ & 0.28 & $1.61^{*}$ & 0.31 & $-3.40^{*}$ & $-0.99^{*}$ & 0.07 & -0.29 \\
\hline & 1.06 & 5.7 & umc1508 & $-8.12^{\star \star \star}$ & $0.61^{* * *}$ & 1.02 & 0.59 & -2.62 & 0.10 & -1.67 & -0.29 \\
\hline & 1.06 & 6.8 & bnlg1598 & $-9.50^{\star * *}$ & 0.24 & 0.59 & 0.44 & $-4.12^{*}$ & $-0.69^{*}$ & -0.68 & -0.31 \\
\hline & 1.06 & 25.6 & umc1035 & $-9.30^{\star \star \star}$ & -0.34 & 1.08 & 0.60 & -2.25 & -0.49 & 0.09 & 0.28 \\
\hline & 1.07 & 15.9 & bnlg0615 & $-4.52^{\star *}$ & 0.34 & 0.46 & 0.26 & $1.39_{\mathrm{oo}}$ & 0.09 & 0.01 & 0.69 \\
\hline & 1.10 & 24.1 & umc1431 & $-2.67^{*}$ & 0.02 & 0.33 & 0.13 & -1.07 & 0.67 & 1.36 & 0.46 \\
\hline & 1.08 & 24.2 & phi0037 & $-3.35^{\star *}$ & 0.14 & 0.93 & 0.41 & 0.40 & 0.81 & -0.45 & 0.36 \\
\hline & 1.11 & 11.6 & phi0120 & -0.34 & -0.46 & -0.65 & -0.24 & $-2.96^{\star}$ & $1.75 。$ & 1.28 & -0.03 \\
\hline & 1.11 & 17.6 & umc1630 & 0.24 & $-1.37^{\star}$ & -1.27 & 0.41 & -2.06 & 0.15 & $1.10^{*}$ & 0.22 \\
\hline & 1.12 & -- & umc1605 & -1.12 & $-1.52^{\star \star}$ & -0.31 & 0.24 & -1.04 & -0.77 & 1.60 & 0.14 \\
\hline \multirow[t]{19}{*}{2} & 2.01 & 4.6 & umc1165 & $2.96^{*}$ & $1.26^{*}$ & -0.10 & -0.01 & $3.96^{\star *}$ & 1.03 & -1.03 & -0.48 \\
\hline & 2.01 & 1.3 & bnlg1338 & $4.14^{*}$ & 1.02 & -0.37 & -0.30 & $2.74^{\star}$ & 0.76 & -0.89 & -0.50 \\
\hline & 2.01 & 1.5 & umc1227 & $3.21^{*}$ & 1.09 & 0.21 & -0.41 & $3.27^{\star *}$ & 0.88 & -0.27 & -0.34 \\
\hline & 2.02 & 2.8 & bnlg1017 & $4.41^{*}$ & 1.21 & -0.28 & -0.48 & 2.27 & 0.88 & -0.79 & -0.12 \\
\hline & 2.02 & 12.9 & umc1265 & $4.05^{\star}$ & $1.39^{*}$ & -0.39 & -0.60 & 2.03 & 1.07 & -1.29 & 0.03 \\
\hline & 2.02 & 8.6 & umc1934 & $9.28^{* * *}$ & 0.36 & 0.66 & -0.23 & 4.28 & 0.30 & 0.19 & -0.33 \\
\hline & 2.02 & 4.0 & bnlg0125 & $9.21^{* * * *}$ & 0.19 & 0.75 & -0.58 & $4.90^{*}$ & -0.57 & 1.01 & -0.17 \\
\hline & 2.03 & 0.9 & umc1845 & $8.55^{\star * * *}$ & -0.09 & 1.33 & $-1.03^{*}$ & 3.57 & -0.37 & 0.87 & -0.05 \\
\hline & 2.03 & 2.5 & umc1776 & $9.12^{* * *}$ & -0.63 & 0.51 & -0.41 & 2.23 & 0.23 & 0.72 & 0.72 \\
\hline & 2.03 & 7.1 & bnlg2248 & $8.27^{* * *}$ & -0.08 & 1.64 & -0.58 & 3.41 & $-1.01^{*}$ & 0.06 & -0.02 \\
\hline & 2.03 & 32.2 & bnlg0381 & $8.92^{* * *}$ & -0.56 & -0.04 & -0.21 & 1.15 & -0.31 & 0.46 & -0.39 \\
\hline & 2.04 & 10.1 & bnlg0166 & $6.64^{* * * *}$ & -0.48 & 0.73 & -0.31 & 0.99 & -0.91 & 0.11 & -1.42 \\
\hline & 2.05 & 19.5 & dupssr21 & $4.42^{* * *}$ & 0.12 & 0.29 & -0.23 & -0.33 & -1.13 & -0.22 & -0.80 \\
\hline & 2.06 & 78.3 & bnlg1396 & $2.57^{\star}$ & 0.55 & 1.06 & -0.38 & 1.95 & -0.91 & -0.60 & -0.74 \\
\hline & 2.07 & 6.3 & umc1560 & $-2.33^{*}$ & $0.39^{*}$ & $2.34^{*}$ & $-0.51^{*}$ & -1.61 & -0.34 & -1.63 & 0.18 \\
\hline & 2.08 & 6.5 & umc1464 & $-2.99^{*}$ & $1.03^{*}$ & 3.01 * & 0.17 & $-0.50_{0}$ & -0.74 & -0.50 & -0.13 \\
\hline & 2.08 & 6.9 & umc1633 & $-3.85^{* *}$ & $0.87^{* *}$ & $2.98^{* *}$ & -0.16 & -1.79 & -0.82 & 0.28 & 0.19 \\
\hline & 2.09 & 4.9 & umc1230 & $-4.29^{* * * *}$ & 0.55 & $3.42^{*}$ & 0.43 & -0.64 & -0.87 & -0.52 & 0.10 \\
\hline & 2.09 & -- & bnlg1520 & $-4.61^{* \star * *}$ & $0.98^{* *}$ & $3.35^{\star}$ & 0.42 & -1.85 & -0.66 & 0.30 & -0.04 \\
\hline \multirow[t]{13}{*}{3} & 3.01 & 17.4 & umc1394 & 1.05 & 0.68 & $1.05^{*}$ & $-0.60^{*}$ & $2.25^{\star *}$ & $-0.31_{\text {ooo }}$ & -2.26 & -0.13 \\
\hline & 3.03 & 27.7 & bnlg1144 & $2.99^{*}$ & -0.50 & 0.36 & -0.26 & $2.22^{*}$ & 0.39 & -2.11 & -0.56 \\
\hline & 3.04 & 7.8 & bnlg1452 & 0.68 & -0.01 & 1.09 & -0.60 & $3.16^{\star}$ & 0.05 & -2.23 & $-0.42^{*}$ \\
\hline & 3.04 & 12.1 & bnlg602 & -0.66 & -0.52 & $1.99^{*}$ & -0.22 & 3.08 & 0.06 & -2.51 & -0.12 \\
\hline & 3.05 & 1.8 & bnlg0420 & $-2.39^{*}$ & 0.01 & 1.40 & $-0.81^{* *}$ & 1.05 & 0.99 。 & -0.17 & 0.41 \\
\hline & 3.05 & 34.1 & $\mathrm{mmc0022}$ & $-3.65^{\star \star}$ & -0.55 & 1.24 & $-0.52^{*}$ & 0.57 & 0.88 & 0.41 & 0.08 \\
\hline & 3.06 & 28.6 & bnlg1798 & $-5.07^{\star * *}$ & 0.47 & -0.80 & 0.16 & 0.04 & 0.74 & 0.06 & 0.36 \\
\hline & 3.07 & 3.3 & umc1690 & -0.26 & -0.65 & -0.87 & -0.45 & 0.45 & 0.04 & 0.70 & -0.81 \\
\hline & 3.07 & 16.0 & umc1659 & 1.07 & -0.45 & -0.40 & -0.06 & 1.84 & 0.12 & 1.14 & -0.69 \\
\hline & 3.08 & 14.1 & umc1320 & $3.04^{*}$ & $-0.99^{*}$ & 0.10 & 0.25 & 3.00 & 0.24 & 0.81 & -0.69 \\
\hline & 3.09 & 2.9 & bnlg1536 & 0.94 & $-1.38^{*}$ & 0.81 & 0.03 & $2.06 。$ & 0.49 & 0.93 & -0.64 \\
\hline & 3.09 & 26.7 & bnlg1754 & 0.71 & -0.71 & 1.15 & -0.37 & 0.34 & 1.32 & 1.33 & -0.74 \\
\hline & 3.10 & -.- & bnlg1098 & $1.78^{*}$ & 0.11 & 1.62 & 0.20 & 2.86 & -0.23 & 0.38 & 0.06 \\
\hline
\end{tabular}


Tabela 19. Estimativas e significâncias dos coeficientes de regressão parciais ( $\beta^{\prime} \mathbf{s}$ ) para os caracteres número de folhas acima da primeira espiga (folhas planta $^{-1}$ ) e teor de umidade nos grãos (\%).

\begin{tabular}{|c|c|c|c|c|c|c|c|c|c|c|c|}
\hline \multirow{2}{*}{\multicolumn{2}{|c|}{$\mathrm{C}^{\mathrm{a}} \mathrm{Bin}$}} & \multirow{2}{*}{$\mathrm{cM}^{\mathrm{b}}$} & \multirow{2}{*}{ Marcador } & \multicolumn{4}{|c|}{ Número de folhas (NF) ${ }^{d}$} & \multicolumn{4}{|c|}{ 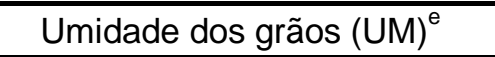 } \\
\hline & & & & $\beta_{1}{ }^{c}$ & $\beta_{2}$ & $\beta_{3}$ & $\beta_{4}$ & $\beta_{1}$ & $\beta_{2}$ & $\beta_{3}$ & $\beta_{4}$ \\
\hline \multirow[t]{19}{*}{4} & 4.01 & 55.7 & umc1276 & $1.50^{*}$ & 0.55 & 0.51 & 0.15 & 0.28 & -0.88 & $1.73^{\star *}$ & -0.15 \\
\hline & 4.04 & 3.4 & umc1652 & -1.59 & 0.24 & 0.50 & -0.26 & 2.40 & -0.11 & 1.44 & -0.49 \\
\hline & 4.05 & 0.1 & phi0026 & -1.75 & 0.63 & 0.99 & -0.42 & 2.13 & 0.44 & 1.88 & -0.58 \\
\hline & 4.05 & 1.7 & umc1088 & $-3.01^{*}$ & 0.13 & 0.91 & -0.28 & $1.36 。$ & 0.34 & $2.12^{*}$ & -0.75 \\
\hline & 4.06 & 35.6 & bnlg0252 & $-2.43^{*}$ & 0.31 & 0.99 & -0.30 & $1.32 。$ & 0.02 & 1.85 & -0.44 \\
\hline & 4.07 & 5.1 & bnlg2291 & $-3.21^{* *}$ & $-1.77^{* *}$ & 0.96 & 0.19 & 0.46 & 0.10 & 0.69 & 0.30 \\
\hline & 4.07 & 18.0 & dupssr34 & $-2.62^{\star *}$ & $-2.10^{* *}$ & 0.77 & -0.20 & 0.41 & -0.64 & 0.81 & 0.29 \\
\hline & 4.08 & 2.0 & bnlg2244 & -0.12 & $-0.99^{*}$ & -0.88 & -0.40 & -1.48 & $-0.46 。$ & 0.09 。 & 0.47 \\
\hline & 4.08 & 4.7 & bnlg2162 & -0.57 & $-1.45^{\star}$ & -1.00 & -0.23 & -1.67 & -0.02 & -0.18 。 & 0.78 \\
\hline & 4.08 & 4.6 & umc1086 & -0.70 & $-1.75^{\star *}$ & 0.04 & -0.06 & $-2.38_{0}$ & 0.17 & $-0.94 。$ & 1.44 \\
\hline & 4.08 & 11.5 & umc1051 & -0.92 & $-0.80^{*}$ & 0.00 & 0.18 & -2.54 & 0.86 & -1.38 & 0.87 \\
\hline & 4.09 & 15.6 & umc1989 & $-2.39^{*}$ & $-1.33^{\star *}$ & 0.17 & -0.02 & -3.17 & 0.31 & -1.23 & 0.67 \\
\hline & 4.09 & 0.6 & phi314704 & 0.01 & $-1.72^{\star *}$ & 0.73 & 0.10 & $-3.40^{*}$ & 0.58 & -1.24 & -0.03 \\
\hline & 4.11 & 0.2 & bnlg0589 & 0.48 & $-1.62^{* *}$ & 0.55 & 0.26 & $-4.83^{* *}$ & -0.11 & -0.24 & $0.72^{*}$ \\
\hline & 4.10 & 0.2 & umc1503 & 0.61 & $-1.54^{\star *}$ & 0.92 & 0.25 & $-3.44^{* *}$ & 0.36 & -1.24 & 0.10 \\
\hline & 4.10 & 5.9 & umc1532 & 0.19 & $-1.65^{\star *}$ & 1.04 & 0.35 & $-3.52^{* *}$ & 0.36 & -1.15 & 0.10 \\
\hline & 4.10 & 6.3 & umc1109 & 0.75 & $-0.97^{*}$ & 1.32 & -0.04 & $-3.04^{*}$ & 0.43 & $-2.04^{*}$ & -0.27 \\
\hline & 4.11 & 6.2 & bnlg1337 & 1.21 & -0.61 & $1.34^{*}$ & -0.04 & -1.55 & -0.15 & -2.10 & -0.75 \\
\hline & 4.11 & --- & umc1197 & 0.83 & $0.66^{*}$ & 0.57 & -0.34 & -1.13 & 0.24 & -1.82 & -1.17 \\
\hline \multirow[t]{16}{*}{5} & 5.00 & 40.7 & bnlg1006 & -0.68 & -0.38 & 1.45 & 0.08 & -1.93 & 0.65 & -0.13 & 0.76 \\
\hline & 5.02 & 8.3 & umc1587 & $4.01^{* *}$ & -0.02 & 0.65 & -0.13 & -0.30 & $1.90^{*}$ & 1.23 & 0.30 \\
\hline & $5.03-04$ & 5.3 & phi0113 & $4.34^{\star *}$ & -0.54 & $1.94^{* * *}$ & 0.24 & 0.05 & $1.53^{\star *}$ & 2.57 & -0.44 \\
\hline & 5.03 & 16.1 & bnlg1879 & $6.03^{\star \star}$ & $-0.82^{\star *}$ & $1.46^{\star}$ & 0.01 & -0.72 & 0.68 & $2.98^{*}$ & -0.30 \\
\hline & 5.03 & 14.1 & umc1056 & $7.08^{\star * \star}$ & $-1.09^{*}$ & 0.82 & -0.31 & -0.87 & 1.08 & $3.68^{*}$ & -0.82 \\
\hline & 5.03 & 9.7 & bnlg1902 & $7.15^{\star \star \star *}$ & -0.90 & 1.23 & -0.24 & -0.01 & $0.85^{\star}$ & $3.26^{\star *}$ & -0.61 \\
\hline & 5.04 & 17.7 & dupssr10 & $5.37^{* * * *}$ & $-1.38^{* *}$ & $1.67^{*}$ & -0.08 & 0.71 & 0.73 & 2.06 & -0.13 \\
\hline & 5.04 & 3.8 & umc1221 & $4.29^{\star *}$ & $-1.24^{*}$ & $1.98^{* *}$ & $-0.83^{* *}$ & $2.61^{* *}$ & 0.77 & 1.92 & -0.36 \\
\hline & 5.05 & 23.5 & $\mathrm{mmc} 0081$ & $4.02^{* *}$ & $-1.49^{*}$ & $1.31^{*}$ & $-0.78^{\star * *}$ & $1.88^{*}$ & 0.46 & $2.00^{\star}$ & -0.44 \\
\hline & 5.06 & 2.1 & umc1019 & $2.46^{\star}$ & $-1.51^{* *}$ & 0.82 & -0.21 & 1.10 & -0.99 & 1.96 & -0.22 \\
\hline & 5.06 & 2.3 & $\mathrm{mmc} 0481$ & $2.29^{*}$ & $-1.26^{*}$ & $1.41^{* *}$ & -0.30 & 1.15 & -0.82 & $2.05^{\star}$ & -0.08 \\
\hline & $5.05-06$ & 1.6 & bnlg278 & $2.53^{*}$ & $-1.37^{*}$ & $1.40^{\star *}$ & -0.46 & 1.53 & -0.42 & 1.70 & -0.13 \\
\hline & 5.06 & 0.1 & umc1680 & $2.40^{*}$ & $-1.00^{*}$ & $1.30^{*}$ & $-0.29^{*}$ & 0.88 & 0.23 & 1.99 & -0.55 \\
\hline & 5.06 & 21.9 & umc1524 & $2.37^{*}$ & $-1.02^{*}$ & $1.28^{*}$ & $-0.30^{*}$ & 0.85 & 0.22 & $2.15^{\star}$ & -0.57 \\
\hline & 5.07 & 32.3 & phi0128 & -0.28 & $-1.35^{*}$ & -0.67 & $0.74^{* *}$ & 0.05 & -0.01 & 0.97 & -0.47 \\
\hline & 5.09 & --- & umc1153 & -0.34 & $1.61^{* * *}$ & -0.96 & 0.03 & 0.81 & 0.19 & -0.64 & 0.21 \\
\hline \multirow[t]{12}{*}{6} & 6.00 & 34.3 & phi0126 & 1.29 & $-1.01^{*}$ & -0.13 & -0.21 & 2.06 & 0.16 & 0.73 & -0.47 \\
\hline & 6.02 & 14.3 & bnlg1371 & $-0.64^{*}$ & -0.21 & 0.08 & $-0.65^{\star}$ & 1.41 & $-1.89^{*}$ & 1.16 & 0.77 \\
\hline & 6.01 & 9.9 & phi0077 & $-1.93^{\star *}$ & -0.37 & 1.19 & -0.44 & $3.34^{*}$ & $-2.68^{*}$ & 0.39 & 0.06 \\
\hline & 6.02 & 0.8 & umc1006 & $-3.40^{\star *}$ & -1.06 & 0.12 & -0.44 & 1.56 & -1.44 & -1.64 & -0.12 \\
\hline & 6.02 & 13.1 & umc1257 & $-3.34^{\star *}$ & $-0.94^{*}$ & 0.42 & -0.41 & 2.19 & -1.59 & -0.89 & -0.10 \\
\hline & 6.03 & 13.9 & umc1887 & $-2.24^{\star *}$ & $-1.66^{\star * *}$ & -0.31 & 0.05 & 0.96 & -0.80 & -1.52 & -0.73 \\
\hline & 6.04 & 18.9 & umc1614 & -0.12 & $-1.08^{*}$ & -0.62 & -0.01 & 0.49 & 0.23 & -0.55 & -0.79 \\
\hline & 6.05 & 22.4 & $\mathrm{nc} 0013$ & 1.91 & -0.30 & 0.10 & -0.31 & -0.54 & -0.79 & -0.51 & -0.21 \\
\hline & 6.06 & 21.2 & umc1520 & $2.53^{*}$ & -0.17 & 0.40 & -0.07 & 0.54 & $0.31 。$ & -1.58 & -0.11 \\
\hline & 6.07 & 11.5 & bnlg1759 & 0.89 & $-1.22^{\star *}$ & 0.10 & 0.05 & -1.78 & -0.07 & -0.97 & 0.06 \\
\hline & 6.07 & 2.6 & umc1653 & 0.65 & -0.51 & 0.25 & $0.41^{*}$ & $-1.07_{\circ \circ}$ & -0.85 & $-1.88^{*}$ & 0.41 \\
\hline & 6.08 & --- & umc1127 & 0.35 & $-0.99^{*}$ & 0.11 & 0.33 & $-0.75_{0}$ & -0.69 & $-1.67^{*}$ & -0.02 \\
\hline
\end{tabular}


Tabela 19. Estimativas e significâncias dos coeficientes de regressão parciais ( $\beta^{\prime} \mathbf{s}$ ) para os caracteres número de folhas acima da primeira espiga (folhas planta $^{-1}$ ) e teor de umidade nos grãos (\%).

\begin{tabular}{|c|c|c|c|c|c|c|c|c|c|c|c|}
\hline \multirow{2}{*}{\multicolumn{2}{|c|}{$\mathrm{C}^{\mathrm{a}} \operatorname{Bin}$}} & \multirow{2}{*}{$\mathrm{cM}^{\mathrm{b}}$} & \multirow{2}{*}{ Marcador } & \multicolumn{4}{|c|}{ Número de folhas $(\mathrm{NF})^{\mathrm{d}}$} & \multicolumn{4}{|c|}{ Umidade dos grãos (UM) $^{\mathrm{e}}$} \\
\hline & & & & $\beta_{1}{ }^{c}$ & $\beta_{2}$ & $\beta_{3}$ & $\beta_{4}$ & $\beta_{1}$ & $\beta_{2}$ & $\beta_{3}$ & $\beta_{4}$ \\
\hline \multirow[t]{9}{*}{7} & 7.00 & 34.5 & umc1426 & 1.25 & $-1.21^{*}$ & $-1.25^{\star}$ & -0.30 & -2.67 & -0.84 & -0.75 & 0.28 \\
\hline & 7.01 & 7.6 & umc1632 & 1.15 & $-1.41^{\star *}$ & 0.90 & -0.38 & -1.27 & $-0.74 。$ & -0.58 & -0.23 \\
\hline & 7.01 & 0.1 & umc1409 & 0.85 & $-1.08^{*}$ & $1.79^{\star *}$ & -0.02 & -1.78 & $-0.32_{0}$ & 0.06 & -0.48 \\
\hline & 7.02 & 28.3 & bnlg1094 & 0.87 & $-1.10^{*}$ & $1.74^{\star *}$ & -0.04 & -1.57 & -0.37 & -0.24 & -0.46 \\
\hline & 7.03 & 39.7 & bnlg0434 & $-1.31^{*}$ & $-1.22^{*}$ & $1.84^{\star *}$ & 0.77 & $-4.58^{*}$ & 0.01 & 0.68 & 0.41 \\
\hline & 7.04 & 32.6 & dupssr13 & 0.24 & $1.55^{\star \star}$ & $-1.45^{\star}$ & 0.19 & $-5.76^{*}$ оо & $1.01_{\mathrm{oo}}$ & -1.00 & 0.56 \\
\hline & 7.05 & 3.2 & umc1154 & 2.15 & -0.59 & -2.42 & -0.48 & $-1.99_{0}$ & 0.18 & -0.57 & -0.47 \\
\hline & 7.05 & 6.7 & umc1407 & 1.91 & 0.02 & -1.27 & -0.18 & -2.76 & 0.58 。 & -0.76 & -0.39 \\
\hline & 7.06 & --- & phi0116 & 0.67 & -0.22 & -1.37 & 0.20 & $-4.06_{\circ o}$ & 1.07 & -0.98 & -0.13 \\
\hline \multirow[t]{11}{*}{8} & 8.01 & 12.1 & umc1139 & 1.84 & $0.41^{* * *}$ & $2.64^{*}$ & 0.19 & $1.62^{*}$ & 0.14 & 0.42 & -0.21 \\
\hline & 8.00 & 14.5 & phi420701 & $1.50^{*}$ & -0.12 & $2.29^{*}$ & 0.34 & 0.34 & 0.00 & -1.57 & -0.21 \\
\hline & 8.02 & 11.9 & phi0119 & $2.41^{*}$ & $0.88^{*}$ & 1.90 & -0.15 & 0.55 & 0.19 & 0.31 & -0.02 \\
\hline & 8.03 & 22.0 & umc1034 & $2.21^{*}$ & 0.22 & 1.44 & -0.20 & -0.51 & -0.48 & 0.94 & -0.33 \\
\hline & 8.04 & 24.4 & bnlg1863 & -0.46 & 0.20 & 0.90 & -0.16 & $3.23_{0}$ & -0.42 & 0.09 & -0.15 \\
\hline & 8.05 & 37.4 & bnlg1176 & 0.76 & 0.09 & $1.81^{*}$ & -0.39 & 0.90 & 0.18 & 1.07 & 0.18 \\
\hline & 8.06 & 12.5 & bnlg1607 & $-2.34^{*}$ & -0.85 & 1.58 & 0.03 & 0.71 & 0.09 & 1.15 & $0.97^{*}$ \\
\hline & 8.07 & 8.9 & bnlg1823 & $-3.88^{\star *}$ & -0.59 & 2.50 & -0.01 & $-0.23_{0}$ & 0.47 & 1.33 & $0.93^{*}$ \\
\hline & 8.08 & 12.1 & umc1005 & $-6.02^{\star \star *}$ & 0.15 & 1.64 & -0.01 & -1.10 & 0.40 & 0.53 & 0.80 \\
\hline & 8.09 & 15.6 & dupssr14 & $-6.03^{\star \star *}$ & 0.74 & 1.05 & -0.05 & -0.25 & -0.40 。 & 0.65 & 0.41 \\
\hline & 8.09 & --- & bnlg1131 & -2.40 & -0.41 & 0.79 & $0.83^{*}$ & 0.15 & -0.27 。 & 1.08 & 0.53 \\
\hline \multirow[t]{10}{*}{9} & 9.02 & 2.4 & umc1170 & 0.41 & -0.15 & 1.03 & $-0.82^{\star *}$ & 3.18 & -0.64 & -1.49 & 0.49 \\
\hline & 9.02 & 11.8 & dupssr06 & 0.52 & $-0.38^{*}$ & 0.90 & $-0.97^{\star *}$ & $3.16_{0 \circ}$ & -0.87 & -0.83 & 0.28 \\
\hline & 9.02 & 4.7 & bnlg1401 & 1.41 & $-0.76^{*}$ & 0.53 & $-0.88^{*}$ & $1.73_{000}$ & $-0.92^{*}$ & -0.71 & -0.29 \\
\hline & 9.02 & 14.0 & umc1893 & 1.99 & $-1.00^{*}$ & 0.35 & -0.40 & $2.81_{00}$ & -0.38 & -0.93 & -0.70 \\
\hline & 9.03 & 12.3 & bnlg0430 & 2.40 & $-0.69^{*}$ & -0.21 & -0.11 & $3.24_{0}$ & $-1.01_{00}$ & -0.97 & -1.01 \\
\hline & 9.04 & 5.6 & umc1107 & 2.77 & -0.44 & 0.99 & 0.05 & 2.93 & 0.21 & -0.54 & $-0.59^{*}$ \\
\hline & 9.05 & 34.1 & bnlg1012 & $3.13^{*}$ & -0.63 & 0.67 & 0.10 & $4.37^{*}$ & 0.64 & 0.36 & 0.10 \\
\hline & 9.06 & 13.8 & umc1733 & 0.36 & 0.38 & -1.56 & 0.35 & 1.82 & 1.44 & 1.54 & -0.65 \\
\hline & $9.07-08$ & 7.8 & bnlg0619 & 0.12 & $-1.20^{*}$ & -0.15 & 0.04 & $4.12^{* *}$ & 1.09 & 0.27 & -0.46 \\
\hline & 9.07 & --- & bnlg0128 & 1.54 & -0.80 & 0.10 & -0.42 & 3.46 & 0.76 & 0.51 & -0.29 \\
\hline \multirow[t]{12}{*}{10} & 10.00 & 9.8 & phi0117 & 0.46 & $0.42^{*}$ & -0.93 & 0.31 & $-2.08^{*}$ & 1.10 & 0.69 & -0.56 \\
\hline & 10.01 & 6.3 & umc1319 & 1.06 & $0.63^{*}$ & -0.89 & 0.20 & $-2.06 。$ & 1.09 & $1.88^{*}$ & -0.04 \\
\hline & 10.02 & 40.7 & bnlg1451 & 1.47 & $0.76^{* *}$ & -0.26 & 0.02 & $-1.66_{\circ o}$ & 0.60 & 1.03 & -0.11 \\
\hline & 10.03 & 7.3 & bnlg0640 & 0.92 & 0.13 & 0.90 & 0.78 & -1.27 & -0.18 & $3.42^{* *}$ & -0.24 \\
\hline & 10.04 & 27.0 & bnlg1526 & -0.12 & 0.36 & 1.07 & $0.93^{*}$ & -0.49 & 0.06 & $2.82^{*}$ & 0.03 \\
\hline & 10.05 & 7.0 & umc1930 & 1.81 & -0.15 & $1.59^{*}$ & 0.18 & 1.19 & -0.75 & $2.46^{*}$ & 0.19 \\
\hline & 10.05 & 12.1 & umc1506 & 2.01 & -0.22 & $1.54^{*}$ & 0.10 & 0.57 & -0.85 & $2.69^{*}$ & -0.22 \\
\hline & 10.07 & 0.2 & umc1196 & $3.33^{*}$ & -0.10 & 1.10 & 0.77 & -1.13 & 0.53 & 1.37 & 0.05 \\
\hline & 10.07 & 0.1 & umc1038 & $4.36^{\star \star}$ & 0.03 & 1.29 & $1.07^{*}$ & 0.05 & 0.20 & 2.39 & 0.22 \\
\hline & 10.07 & 0.1 & umc2021 & 2,37 & 0,63 & 1,27 & 0,75 & $-1,22$ & 0,60 & 1,47 & 0,32 \\
\hline & 10.07 & 1.4 & umc1569 & $2,86^{*}$ & 0,44 & $2,32^{*}$ & 0,91 & 0,07 & 0,03 & 2,68 & $0,62^{*}$ \\
\hline & 10.07 & --- & bnlg1839 & $3,83^{*}$ & $-0,47$ & 0,22 & 0,37 & $-1,37$ & 0,52 & 1,30 & 0,34 \\
\hline
\end{tabular}




\section{REFERÊNCIAS BIBLIOGRÁFICAS}

AGRAMA, H.A.S.; MOUSSA, M.E. Mapping QTLs in breeding for drought tolerance in maize (Zea mays L.). Euphytica, v.91, p.89-97, 1996.

AJMONE-MARSAN, P.; GORNI, C.; CHITTÒ, A.; RADAELLI, R.; VAN VIJK, R.; STAM, P.M. Identification of QTLs for grain yield and grain-related traits of maize (Zea mays L.) using AFLP map, different testers, and cofactor analysis. Theoretical and Applied Genetics, v.102, p.230243, 2001.

AJMONE-MARSAN, P.; MONFREDINI, G.; LUDWIG, W.F.; MELCHINGER, A.E.; FRANCESCHINI, P. Identification of genomic regions affecting plant height and their relationship with grain yield in an elite maize cross. Maydica, v.39, p.133-139, 1994.

AKKAYA, M.S.; BHAGWAT, A.A.; CREGAN, P.B. Length polymorphisms of simple sequence repeat DNA in soybean. Genetics, v.132, p.11311139, 1992.

ALLARD, R.W. Principles of plant breeding. New York: John Wiley, 1960. $485 p$.

AUSTIN, D.F.; LEE, M.; VELDBOOM, R.L.; HALLAUER, A.R. Genetic mapping in maize with hybrid progeny across testers and generations: grain yield and grain moisture. Crop Science, v.40, p.30-39, 2000

ALLISON, J.C.S.; WATSON, D.J. Production and Distribution of Dry Matter in Maize After Flowering. Annals of Botany, v.30, p.365, 1966.

BARBIN, D. Componentes de variância: teoria e aplicações. 2.ed. Piracicaba: FEALQ, 1993. 120p. 
BARENDSE, W; ARMITAGE, S.M.; KOSSAREK, L.M.; SHALOM, A.; KIRKPATRICK, B.W.; RYAN, A.M.; CLAYTON, D.; LI, L.; NEIBERGS, H.L.; ZHANG, N.; GROSSE, W.M.; WEISS, J.; CREIGHTON. P.; MCCARTHY, F.; RON, M.; TEALE, A.J.; FRIES, R.; MCGRAW, R.A.; MOORE, S.S.; GEORGES, M.; SOLLER, M.; WOMACK, J.E.; HETZEL, D.J.S. A genetic-linkage map of the bovine genome. Nature Genetics, v.6, n.3, p.227-235, 1994.

BEARZOTI, E. Mapeamento de QTL. In: PINHEIRO, J.B. Análise de QTL no melhoramento de plantas: segunda jornada em Genética e melhoramento de plantas. Goiânia: FUNAPE, 2000. p.63-209.

BEAVIS, W.D.; GRANT, D.A. Linkage map based on information from four $\mathrm{F}_{2}$ populations of maize (Zea mays L.). Theoretical and Applied Genetics, v.82, p.636-644, 1991.

BECKER, J.; HEUN, E. Barley microsatellites: Allele variation and mapping. Plant Molecular Biology, v.27, p.835-845, 1995.

BECKMANN, J.S.; SOLLER, M. Restriction fragment lenght polymorphisms in plant genetic improvement. In: MIFLIN BJ, (Ed.) Oxford surveys of plant molecular \& cell biology. Oxford: Oxford University Press, 1986. v.3, p.196-250.

BECKMANN, J.S.; SOLLER, M. Towards unified approach to the genetic mapping of eukaryotes based on sequence-tagged microsatellite sites. Bio/Technology, v.8, p.930-932, 1990.

BERKE, T.G.; ROCHEFORD, T.R. Quantitative trait loci for flowering, plant and ear height, and kernel traits in maize. Crop Science, v.35, p.15421549, 1995.

BOLAÑOS, J.; EDMEADES, G.O. Eight cycles of selection for drought tolerance in lowland tropical maize. I. Responses in reproduce behavior. Field Crops Research, v.31, p.253-268, 1993.

BOLAÑOS, J.; EDMEADES, G.O. The importance of the anthesis-silking interval in breeding for drought tolerance in tropical maize. Field Crops Research, v.48, p.65-80, 1996. 
BOTSTEIN, D.; WHITE, R.L.; SKOLNICK, M.E.; DAVIS, R.W. Construction of a genetic linkage map in man using restriction fragment length polymorphisms. Americam Journal of Human Genetics, v.32, p.314331, 1980.

BROOKS, L.D. The evolution of recombination rates. In: MICHOD, R.E.; LEVIN, B.R. (ed.). The evolution of sex. Sunderland: Sinauer Association, 1988, p.87-105.

BURR, B.; BURR, F.A.; THOMPSON, K.H.; ALBERTSEN, M.C.; STUBER, C.W. Gene mapping with recombinant inbreds in maize. Genetics, v.118, p.519-526, 1988.

BYRNE, P.F.; MCMULLEN, M.D.; SNOOK, M.E.; MUSKET, T.; THEURI, J.M. Quatitative trait loci and metabolic pathways: genetic control of concentration of maysin, a corn earworn resistance factor, in maize silks. Proceedings of the National Academy of Sciences of the United States of America, v.93, p.8820-8825, 1996.

CASTIGLIONI, P.; AJMONE-MARSAN, P.; VAN WIJK, R.; MOTTO, M. AFLP markers in a molecular linkage map of maize: codominant scoring and linkage group distribution. Theoretical and Applied Genetics v.99, p.425-431, 1999.

CHIN, E.C.L.; SENIOR, M.L.; SHU, H.; SMITH, J.C.S. Maize simple repetitive DNA sequences: abundance and allele variation. Genome, v.39, p.866-873, 1996.

CHURCHILL, G.A.; DOERGE, R.W. Empirical threshold values for quantitative trait mapping. Genetics, v.138, p.963-971, 1994.

COCKERHAM, C. C.; ZENG, Z.-B. Design III with marker loci. Genetics, v.143, p1437-1456, 1996.

COE, E.H.; HOISINGTON, D.A.; NEUFFER, M.G. Linkage map of corn (maize) (Zea mays L.). Maize Genetics Cooperation Newsletter, v.61, p.116-147, 1987.

COELHO, A.S.G. Considerações gerais sobre a análise de QTLs. In: PINHEIRO, J.B. Análise de QTL no melhoramento de plantas: segunda jornada em Genética e melhoramento de plantas. Goiânia: FUNAPE, 2000. p.1-20. 
COMSTOCK, R.E.; ROBINSON, H.F. Estimation of average dominance genes. In: GOWEN, J.W. (Ed.) Heterosis. Ames: lowa State College Press, 1952. cap.30, p.494-516.

CONDIT, R.; HUBBELL, S.P. Abundance and DNA sequence of two-base regions in tropical tree genomes. Genome, v.34, p.66-71, 1991.

COWEN, N.M. The use of replicated progenies in marker-based mapping of QTLs. Theoretical and Applied Genetics, v.75, p.857-862, 1988.

DAVIS, G.L.; MCMULLEN, M.D.; BAYSDORFER, C.; MUSKET. T.; GRANT. D.; STAEBELL. M.; XU, G.; POLACCO, M.; KOSTER. L.; MELIAHANCOCK, S.; HOUCHINS, K.; CHAO, S.; COE, E.H. A maize map standard with sequenced core markers, grass genome reference points and 932 expressed tagged sites (ESTs) in a 1736-locus map. Genetics, v.152, p.1137-1172, 1999.

DOERGE, R.W.; CHURCHILL. G.A. Permutation tests for multiple loci affecting a quantitative character. Genetics, v.142, p.285-294, 1996.

DON, R.H.; COX, P.T.; WAINWRIGHT, B.J.; BAKER, K; MATTICK, J.S. Touchdown PCR to circumvent spurious priming during gene amplification. Nucleic Acid Reseach, v.19, p.4008, 1991.

DUDLEY, J. W. Molecular markers in plant improvement: manipulation of genes affeting quantitative traits. Crop Sciences, v.33, p.660-668, 1993.

DUDLEY, J.W. Linkage disequilibrium in crosses between Illinois maize strains divergently selected for protein percentage. Theoretical and Applied Genetics, v.87, p.1016-1020, 1994.

EDWARDS, A.; CIVITELLO, A; HAMMOND, H.A.; CASKEY, C.T. DNA typing and genetic mapping with trimeric and tetrameric tandem repeats. Americam Journal of Human Genetics, v.49, p.746-756, 1991.

EDWARDS M.D.; STUBER C.W.; WENDEL J.F. Molecular-marker-facilited investigations of quantitative trait loci in maize. 1. Numbers, genomic distribution and types of gene action. Genetics, v.116, p.113-125, 1987. 
EDWARDS, M.D.; HELENTJARIS, T.; WRIGHT, S.; STUBER, C.W. Molecular-marker-facilitated investigations of quantitative trait loci in maize. 4. Analysis based on genome saturation with isozyme and restriction fragment length polymorphisms markers. Theoretical and Applied Genetics, v.83, p.765-774, 1992.

EPPLEN, J. T.; MELMER, G.; SCHMIDT, P.; ROEWER, L.; HUNDRIESER, J.; EPPLEN, C.; BUITKAMP, J. On the potential of simple repetitive DNA for fingerprinting in clinical forensic and evolutionary studies. Clinical Investigation Medicals, v.70, p.1043-1051, 1992.

FALCONER, D.S.; MACKAY, T.F.C. Introduction to quantitative genetics. Harlow: Addison Wesley Longman, 1996. 464p.

GARDNER, C.O.; HARVEY, R.E.; COMSTOCK, R.E.; ROBINSON, H.F. Dominance of genes controlling quantitative characters in maize. Agronomy Journal, v.45, p.186-191, 1953.

GARDNER, C.O. Estimates of genetic parameters in cross-fertilizing plant in their implications in plant breeding. In: HANSON, W.D.; ROBINSON, H.F. (Ed.). Statistical genetics and plant breeding. Washington: National Academy of Sciences, National Research Council, 1963. p.225-252.

GARDNER, C.O.; LONNQUIST, J.H. Linkage and the degree of dominance of genes controlling quantitative characters in maize. Agronomy Journal, v.51, p.524-528, 1959.

GARDNER, J.; COE, E.H.; MELIA-HANCOCK, S.; HOISINGTON, D.A.; CHAO, S. Development of a core RFLP map in maize using an imortalized- $F_{2}$ population. Genetics, v.134, p.917-930, 1993.

GELDERMANN, H. Investigations on inheritance of quantitative characters in animals by gene markers. I. Methods. Theoretical and Applied Genetics, v.46, p.319-330, 1975

GOMES, F.P. Curso de estatística experimental. São Paulo: Livraria Nobel, 1990. 430p.

GRODZICKER T.; WILLIANS J.; SHARP P.; SAMBROOK J. Physical mapping of temperature-sensitive mutations of adenoviroses. Cold Spring Harbor Symposium Quantitative Biology, v.39, p.439-446, 1974. 
GUEI, R.G.; WASSOM, C.E. Inheritance of some drought adaptive traits in maize: I. Interrelationships between yield, flowering, and ears per plant. Maydica, v.37, p.157-164, 1992.

GUILFORD, W.G.; LAWOKO, C.R.O.; ALLAN, F.J. Accuracy of localizing radiopaque markers by abdominal radiography and correlation between their gastric emptying rate and that of a canned food in dogs American Journal of Ceterinary Research, v.58, n.12, p.1359-1363, 1997.

HALDANE, J.B.S. The recombination of linkage values and the calculation of distance between the loci of linkage factors. Journal of Genetics, v.8, p.299-309, 1919.

HAN, G.-C; HALLAUER, A.R. Estimates of genetic variability in $F_{2}$ maize populations. Journal lowa Academic Science, v.96, p.14-19, 1989.

HANCOCK, J.M.; DOVER, G.A. Molecular coevolution among cryptically simple expansion segments of eukaryotic 26s/28s ribosomal-rnas. Molecular Biology and Evolution, v.5, n.4, p.377-391, 1988.

HELENTJARIS, T.; SLOCUM, M.; WRIGHT, S.; SCHAEFER, A.; NIENHUIS, J. Construction of genetic linkage maps in maize and tomato using restriction fragment length polymorphisms. Theoretical and Applied Genetics, v.72, p.761-769, 1986.

HERRERO, M.P.; JOHNSON, R.R. Drought stress and it effects on maize reproductive systems. Crop Science, v.21, p.105-110, 1981.

HOISINGTON D, KHAIRALLAH M.M.; GONZÁLEZ-DE-LÉON D. Laboratory protocols. CIMMYT applied molecular genetics laboratory. 2.ed. Mexico: CIMMYT, 1994. 180p.

HOLM, S. A simple sequentially rejective multiple teste procedure. Scandinavian Journal of Statistical, v.6, p.65-70, 1979.

HOYT, P.; BRADFIELD, R. Effect of varying leaf area by partial defoliation and plant densityon dry matter production in corn. Agronomy Journal, v.54, n.6, p.523, 1962.

JANSEN, R.C. A general mixture model for mapping quantitative trait loci by using molecular markers. Theoretical and Applied Genetics, v.85, p.252-260, 1992.

JANSEN, R.C. Maximum likelihood in a generalized linear finite mixture model by using the EM algorithm. Biometrics, v.49, p.227-231, 1993. 
JANSEN, R.C.; STAM, P. High resolution of quantitative traits into multiple loci via interval mapping. Genetics, v.136, p.1447-1455, 1994.

JANSEN, R.C.; VAN OOIJEN, J.W.; STAM, P.; LISTER, C.; DEAN, C. Genotype-by-environment interaction in genetic mapping of multiple quantitative trait loci. Theoretical and Applied Genetics, v.91, p.33-37, 1995.

JARRET, R.L.; MERRICK, L.C.; HOLMS, T.; EVANS, J.; ARADHYA, M.K. Simple sequence repeats in watermelon (Citrullus lanatus (Thunb) Matsum \& Nakai). Gemome, v.40, n.4, p.433-441, 1997.

JENSEN, J. Estimation of recombination parameters between a quantitative trait locus (QTL) and two marker gene loci. Theoretical and Applied Genetics, v.78, p.613-618, 1989.

JIANG C.; ZENG Z.B. Multiple trait analysis of genetic mapping for quantitative trait loci. Genetics, v.140, p.1111-1127, 1995.

KARP, A.; SEBERG, O.; BUIATTI, M. Molecular techniques in the assessment of botanical diversity. Annals of Botany, v.78, p.143-149, 1996.

KEIM, P.; DIERS, B.W.; SHOEMAKER, R.C. Genetic analysis of soybean hard seedeness with molecular markers. Theoretical and Applied Genetics, v.79, p.465-469, 1990.

KEMPTHORNE, O. An introduction to genetic satatistics. New York: John Wiley, 1957.

KHAIRALLAH, M.M.; BOHN, M.; JIANG; C.; DEUTSCH, J.A.; JEWELL, D.C., MIHM, J.A.; MELCHINGER, A.E.; GONZÁLEZ-de-LEÓN, D.; HOISINGTON, D.A. Molecular mapping of QTL for southwestern corn borer resistance, plant height and flowering $\mathrm{n}$ tropical maize. Plant Breeding, v.117, p.309-318, 1998.

KNAPP, S.J.; STROUP, W.W.; ROSS, W.M. Exact confidence intervals for heritability on a progeny mean basis. Crop Science, v.25, p.192-194, 1985.

KNAPP, S.J.; BRIDGES, W.C.; BIRKES, D. Mapping quantitative trait loci using molecular maker linkage maps. Theoretical and Applied Genetics, v.79, p.583-592, 1990. 
KOSAMBI, D.D. The estimation of map distances from recombination values. Annual Eugenics, v.12, p.172-175, 1944.

LANDER, E.S.; BOTSTEIN, D. Mapping mendelian factors underlying quantitative traits using RFLP linkage maps. Genetics, v.121, p.185199, 1989.

LANDER, E.S.; GREEN, P.; ABRAHAMSON, J.; BARLOW, A.; DALY, M.J.; LINCOLN, S.E.; NEWBURG, L. Mapmaker: an interactive computer package for constructing primary genetic linkage maps of experimental and natural populations. Genomics, v.1, p.174-181, 1987.

LANGERCRANTZ, U.; ELLEGREN, H.; ANDERSON, L. The abundance of various polymorphic microsatellite motifs differs between plants and vertebrates. Nucleic Acids Research, v.21, p.1111-1115, 1993.

LEBRETON, C.; LAZIC-JANCIC, V.; STEED, A.; PEKIC, S.; QUARRIE, S.A. Identification of QTL for drought responses in maize and their use in testing causal relationships between traits. Journal of Exprimental Botany, v.46, p.853-865, 1995.

LEVINSON, G.; GUTMAN, G. A. Slipped-strand mispairing: a major mechanism for DNA sequence evolution. Molecular Biology Evolution, v.4, p.203-221. 1987.

LINCOLN, S.E.; DALY, M.J.; LANDER, E.S. Constructing genetic maps whith Mapmaker Exp 3.0. 3.ed. Cambridge: Whitehead Institute for Biometrical Research, 1992. 230p.

LITT, M.; LUTTY, J.A. A hypervariable microsatellite revealed by in vitro amplification of a dinucleotide repeat within the cardiac muscle actin gene. Americam Journal of Human Genetetics, v.44, p.398-401, 1989.

LIU, B.H. QTL mapping: future considerations. In: LIU, B.H. (Ed.). Statistical genomics. New York: CRC Press, 1998. 611p.

LIU, B.H.; KNAPP, S.J. G. Mendel: a program for mendelian segregation and linkage analysis of individual or multiple progeny populations using log-likelihood ratios. Journal of Heredity, v.81, p.407, 1992.

LONNQUIST, J.H. Mass selection for prolificacy in maize. Der Zucther, v.37, p.185-188, 1967. 
LUBBERSTEDT, T.; MELCHINGER, A.E.; SCHON, C.C.; UTZ, H.; KLEIN, D. QTL mapping testcrosses of European flint lines of maize. 1. Comparison of different testers for forage yield traits. Crop Science, v.37, p.921-931, 1997.

LYNCH, M.; WALSH, B. Genetics and analysis of quantitative traits. Sunderland: Sinauer Associates, 1998. 980p.

MACKAY, T.F.C. Quantitative trait in Drosophila. Nature Reviews Genetics, v.2, p.11-20, 2001.

MATHER, K; JINKS, J.L. Biometrical genetics. 3.ed. New York: Chapman and Hall, 1982. 382p.

MELCHINGER, A.E.; UTZ, H.F., SCHÖN, C.C. Quantitative trait locus (QTL) mapping using different testers and independent population samples in maize reveals low power of QTL detection and large bias in estimates of QTL effects. Genetics, v.149, p.383-403, 1988.

MILACH, S.C.K. Marcadores moleculares em plantas. Porto Alegre: UFRGS, 1998. 187p.

MOLL, R.H.; LINDSEY, M.F.; ROBINSON, H.F. Estimates of genetic variances and level of dominance in maize. Genetics, v.49, p.411-423, 1964.

MORENO-GONZÁLEZ, J.; DUDLEY, J.W.; LAMBERT, R.J. A design III study of linkage desequilibrium for percent oil in maize. Crop Science, v.15, p.840-843, 1975.

MORGANTE, M.; OLIVIERI, A.M. PCR-amplified microsatellites as markers for plant genetics. Plant Journal, v.3, p.175-182, 1993.

MORGANTE, M.; RAFALSKI, A.; BIDDLE, P.; TINGEY, S.; OLIVIERI, A.M. Genetic mapping and variability of seven soybean simple sequence repeat loci. Genome, v.37, p.763-769, 1994.

OGLIARI, J.B. Identificação e localização de um gene de resitência de milho a Exserohilum turcicum (Pass.) Leonard \& Suggs através do uso de marcadores microssatélites. Piracicaba, 1999. 115p. Tese (Doutorado) Escola Superior de Agricultura "Luiz de Queiroz", Universidade de São Paulo. 
PATERSON, A.H; DAMON, S.; HEWITT, J.D; ZAMIR, D.; RABINOWITCH, H.D.;LINCOLN. S.E; LANDER, E.S.; TANKSLEY, S.D. Mendelin factors underlying quantitative traits in tomato: comparison across species, generations , and environments. Genetics, v.127, p.181-197, 1991.

PIZAIA, A. Seleção para prolificidade em populações de milho (Zea mays L.). Piracicaba, 2000. 146p. Tese (Doutorado) - Escola Superior de Agricultura "Luiz de Queiroz", Universidade de São Paulo.

POWELL, W.; MACHRAY, G.C.; PROVAN, J. Polymorphism revelead by simple sequence repeats. Trends in Plant Science, v.1, n.7, p.215222, 1996.

PRIOUL, J.; QUARRIE, S.; CAUSSE, M.; VIENNE, D. Dissecting complex physiological functions through the use molecular quantitative genetics. Journal of Experimental Botany, v.48, p.1151-1163, 1997.

PROVINCE, M.A. Sequencial methods of analysis for genome scans. Advances in Genetics, v.42, p.499-514, 2001.

RIBAUT, J.-M.; JIANG, C.; GONZALEZ-de-LEÓN; D.; EDMEADES, G.O.; HOISINGTON, D.A. Identification of quantitative trait loci under drought conditions in tropical maize. 2. Yield components and marker-assisted selection strategies. Theoretical and Applied Genetics, v.94, p.887896, 1997.

ROBINSON, H.F.; COMSTOCK, R.E.; HARVEY, P.H. Estimates of heritability and degree of dominance in corn. Agronomy Journal, v.41, p.353-359, 1949.

ROBINSON, H.F.; COMSTOCK, R.E.; HARVEY, P.H. Genetic variances in open pollinated varieties of corn. Genetics, v.40, p.45-60. 1955.

RÖDER, M.S.; PLASCHKE, J.; KÖNIG, S.U.; BÖRNER, A.; SORRELLS, M.E.; TANKSLEY, S.D.; GANAL, M.W. Abundance, variability and chromosomal location of microsatellites in wheat. Molecular General Genetics, v.246, p.327-333, 1995.

SAIKI, R.K.; SCHARF, S.; FALOONA, F.; MULLIS, K.B.; HORN, G.T.;ERLICH, H.A.; ARNHEIN, N. Enzimatic amplification of B-globin genomic sequences and restriction site analysis for diagnosis of sickle cell anemia. Science, v.230, p.1350-1354. 1985. 
SAKIYAMA, N.S. Marcadores moleculares e as hortaliças. Horticultura Brasileira, v.11, n.2, p.204-206, 1993.

SAS INSTITUTE. SAS OnlineDoc®: version 8. Cary, 1999.

SENIOR, M.L.; CHIN, E.C.L.; LEE, M.; SMITH, J.S.C.; STUBER, C.W. Simple sequence repeat markers developed from maize sequences found in the GenBank database: map construction. Crop Science, v.36, p.1676-1683, 1996.

SENIOR, M.L.; HEUN, M. Mapping maize microsatellites and polymerase chain reaction confirmation of the targeted repeats using a CT primer. Genome, v.36, p.884-889, 1993.

SOLLER, M.; BRODY, T.; GENIZI, A. On the power of experimental designs for the detection of linkage between marker loci and quantitative loci in crosses between inbreed lines. Theoretical and Applied Genetics, v.47, p.35-39, 1976

SOLLER, M.; BECKMANN, J.S. Genetic polymorphism in varietal identification and genetic improvement. Theoretical and Applied Genetics, v.67, p.25-33, 1983.

SOLLER, M.; BRODY, T. On the power of experimental designs for the detection of linkage between marker loci and quantitative loci in crosses between inbreed lines. Theoretical and Applied Genetics, v.47, p.3539, 1976.

SOLOMON, M.; BODMER, W. F. Evolution of sikle variant genes. Lancet, v.1, p.8122-8123, 1979.

SOUZA, A.P. Biologia molecular aplicada ao melhoramento. In: NASS, L.L.; VALOIS, A.F.C.C.; MELO, I.S.; VALADARES-INGLIS, M.V. (Eds.). Recursos genéticos e melhoramento de plantas. Rondonópolis: Fundação MT, 2001. p.913-965.

SOUZA JÚNIOR, C.L.; SANTOS, M.X.; MAGNAVACA, R.; GAMA, E.E.G. Estimativas de parâmetros genéticos na interpopulação de milho BR105 x BR-106 e suas implicações no melhoramento. Pesquisa Agropecuária Brasileira, v.28, p.473-479, 1993.

SOUZA JÚNIOR, C.L.; GERALDI, I.O.; ZINSLY, J.R. Influence of tassel size on the expression of prolificacy in maize (Zea mays L.). Maydica, v.30, p.321-328, 1985. 
STAM, P. Construction of integrated genetic linkage maps by means of a new computer package: JoinMap. Plant Journal, v.3, p.739-744, 1993.

STEEL, R. G. D.; TORRIE, J. H. Principles and procedures of statistics. New York: McGraw-Hill Book Company, 1980. cap.5, p.86-121.

STRUICK, P.C.; DOORGEEST, M. ; BOONMAN, J.G. Environmental effects on flowering characteristics and kernel set of maize (Zea mays L.). Netherlands Journal of Agricultural Science, v.34, p.469-484, 1989.

STUBER, C.W.; EDWARDS, M.D.; WENDEL, J.F. Molecular markerfacilites investigations of quantitative trait loci in maize. II. Factors influencing yield and its components traits. Crop Science, v.27, p.639648, 1987.

STUBER, C.W.; LINCOLN, S.E.; HELENTJARIS, T.; LANDER, E.S. Identification of genetic factors contributing to heterosis in a hybrid from two maize imbred lines using molecular markers. Genetics, v.132, p.823-839, 1992.

TANKSLEY, S. D. 1993. Mapping polygenes. Annual Review of Genetics, v.27, p.205-233.

TARAMINO, G.; TINGEY, S. Simple sequence repeats for germoplasm analysis and mapping in maize. Genome, v.39, p.277-287, 1996.

TARAMINO, G.; TARCHINI, R.; FERRARIO, S.; LEE, M.; PE, M.E. Characterization and mapping of simple sequence repeats (SSRs) in Sorghum bicolor. Theoretical and Applied Genetics, v.95, p.66-72, 1997.

TAUTZ, D. Hypervariability of simple sequences as a general source for polymorphic DNA markers. Nucleic Acid Research, v.17, n.16, p.64636471, 1989.

TAUTZ, D; TRICK, M.; DOVER, G.A. Cryptic simplicity in DNA is a major source of genetic variation. Nature, v.322, p.652-656, 1986.

THODAY, J.M. Location of polygenes. Nature, v.191, p.368-370, 1961.

THOMAS, M.R.; SCOTT, N.S. Microsatellite repeats in grapevine reveal DNA polymorphisms when analyzed as sequence-tagged sites (STSs).

Theoretical and Applied Genetics, v.86, p.985-990, 1993. 
VELDBOOM, L.R.; LEE, M. Genetic mapping of quantitative trait loci in maize in stress and nonstress environments: I. Grain yield and yield components. Crop Science, v.36, p.1310-1319, 1996.

VELDBOOM, L.R.; LEE, M.; WOODMAN, W.L. Molecular-marker-facilited studies in an ellite maize population. 1. Linkage analysis and determination of QTL for morphological traits. Theoretical and Applied Genetics, v.88, p.7-16, 1994.

VENCOVSKY, R. Herança quantitativa. In: PATERNIANI, E.; VIÉGAS, G.P. (Coord.). Melhoramento e produção de milho no Brasil. Piracicaba: Fundação Cargill, 1987. v.1, p.135-214.

VENCOVSKY, R.; BARRIGA, P. Genética biométrica aplicada ao fitomelhoramento. Ribeirão Preto: Sociedade Brasileira de Genética, 1992. $496 \mathrm{p}$.

VOS, P.; HOGERS, R.; BLEEKER, M.; REIJANS, M.; LEE, T.; HORNES, M.; FRIJTERS, A.; POT, J.; PELEMAN, J.; KUIPER, M.; ZABEAU, M. AFLP: a new technique for DNA fingerprinting. Nucleic Acids Research, v.23, p.4407-4414, 1995.

VUYLSTEKE, M.; MANK, R.; ANTONISE, R.; BASTIAANS, E., SENIOR, M.L.; STUBER, C.W.; MELCHINGER, A.E.; LUBBERSTEDT; XIA, X.C.; STAM, P.; ZABEAU, M.; KUIPER, M. Two high-density AFLP linkage maps of Zea mays L.: analysis of distribution of AFLP markers. Theoretical and Applied Genetics, v.99, p.921-935, 1999.

WEBER, J.L.; MAY, P.E. An abundant class of human DNA polymorphism which can be typed using the polymerase chain reaction. American Journal of Human Genetics, v.44, p.388-396, 1989.

WELLER, J.I. Maximum likelihood techniques for the mapping and analysis of quantitative trait loci with the aid of genetic markers. Biometrics, v.42, p.627-640, 1986.

WILLIAMS, J.G.K.; KUBELIK, A.R.; LIVAK, K.J.; RAFALSKI, J.A.; TINGEY, S.V. DNA polymorphisms amplified by arbitrary primers are useful as genetic markers. Nucleic Acids Reserach, v.18, p.6531-6535, 1990.

WOLF, D.P.; PETERNELLI, L.A.; HALLAUER, A.R. Estimates of genetic variance in an $F_{2}$ maize population. The Journal of Heredity, v.91, p.384-391, 2000. 
WU, K.; TANKSLEY, S.D. Abundance, polymorphism and genetic mapping of microsatellites in rice. Molecular General Genetics, v.241, p.225235, 1993.

YOUNG, N.D. Constructing a plant genetic linkage map with DNA markers. In: PHILLIPS, R.L.; VASIL, I.K. DNA: based markers in plants. Dordrecht: Kluwer Academic, 1994. p.39-57.

ZENG, Z.-B. Theoretical basis for separation of multiple linked gene effects in mapping quantitative trait loci. Proceedings of the National Academy of Sciences of the United States of America, v.90, p.10972-10976, 1993.

ZENG, Z.-B. Precision mapping of quantitative trait loci. Genetics, v.136, p.1457-1466, 1994. 


\section{APÊNDICES:}

Tabelas de ANAVAS por ambientes e de covariâncias 
Tabela 20. Análises de variâncias agrupadas por ambientes, coeficiente de variação e médias dos 10 caracteres avaliados.

\begin{tabular}{|c|c|c|c|c|c|c|c|c|}
\hline Caráter & Fonte de variação & $\mathrm{GL}$ & Amb 1 & Amb 2 & Amb 3 & Amb 4 & Amb 5 & Amb 6 \\
\hline $\begin{array}{c}\text { PG } \\
\left(\text { g planta }^{-1}\right)\end{array}$ & $\begin{array}{l}\text { Prog /Exp } \\
\text { ProgxLinh /Exp } \\
\text { Resíduo } \\
\text { CV } \\
\text { Média }\end{array}$ & $\begin{array}{l}245 \\
245 \\
404\end{array}$ & $\begin{array}{c}564,18^{\text {** }} \\
685,95^{\text {** }} \\
356,78 \\
15,47 \\
122,06\end{array}$ & $\begin{array}{c}582,89^{* *} \\
746,83^{* *} \\
321,35 \\
12,99 \\
137,97\end{array}$ & $\begin{array}{c}594,92^{* \star} \\
879,14^{\star *} \\
330,22 \\
12,32 \\
147,50\end{array}$ & $\begin{array}{c}400,38^{* *} \\
563,60^{\star *} \\
168,11 \\
13,77 \\
94,19\end{array}$ & $\begin{array}{c}414,77^{* *} \\
528,24^{* *} \\
218,20 \\
13,84 \\
106,72\end{array}$ & $\begin{array}{c}415,19^{* \star} \\
525,32^{* *} \\
254,12 \\
17,28 \\
92,25\end{array}$ \\
\hline $\begin{array}{c}\mathrm{PRO}^{(2)} \\
\left(\text { Espigas planta }^{-1}\right)\end{array}$ & $\begin{array}{l}\text { Prog /Exp } \\
\text { ProgxLinh /Exp } \\
\text { Resíduo } \\
\text { CV } \\
\text { Média }\end{array}$ & $\begin{array}{l}245 \\
245 \\
404\end{array}$ & $\begin{array}{c}2,08^{* *} \\
2,40^{* *} \\
1,58 \\
12,45 \\
1,01\end{array}$ & $\begin{array}{c}3,18^{* *} \\
2,96^{*} \\
2,34 \\
13,51 \\
1,13\end{array}$ & $\begin{array}{c}2,83^{* *} \\
2,74^{* *} \\
1,93 \\
12,16 \\
1,14\end{array}$ & $\begin{array}{c}3,42^{* *} \\
2,43^{*} \\
1,92 \\
13,05 \\
1,06\end{array}$ & $\begin{array}{c}2,84^{* *} \\
2,82^{* *} \\
2,14 \\
13,03 \\
1,12\end{array}$ & $\begin{array}{c}3,04^{\star *} \\
2,56^{*} \\
2,12 \\
13,56 \\
1,07\end{array}$ \\
\hline $\begin{array}{c}\text { AE } \\
\left(\mathrm{cm} \mathrm{planta}^{-1}\right)\end{array}$ & $\begin{array}{l}\text { Prog /Exp } \\
\text { ProgxLinh /Exp } \\
\text { Resíduo } \\
\text { CV } \\
\text { Média }\end{array}$ & $\begin{array}{l}245 \\
245 \\
405\end{array}$ & $\begin{array}{c}142,35^{* *} \\
121,98^{* *} \\
58,28 \\
7,42 \\
102,84\end{array}$ & $\begin{array}{c}114,06^{* *} \\
73,57^{* *} \\
51,82 \\
6,14 \\
117,32\end{array}$ & $\begin{array}{c}111,05^{* *} \\
72,28^{* *} \\
46,22 \\
5,63 \\
120,86\end{array}$ & $\begin{array}{c}56,42^{* *} \\
49,69^{* *} \\
35,63 \\
5,38 \\
110,87\end{array}$ & $\begin{array}{c}83,29^{* *} \\
78,55^{* *} \\
50,53 \\
6,91 \\
102,86\end{array}$ & $\begin{array}{l}85,39^{* *} \\
61,92^{* *} \\
47,11 \\
7,04 \\
97,47\end{array}$ \\
\hline $\begin{array}{c}\text { AP } \\
\left(\mathrm{cm} \mathrm{planta}^{-1}\right)\end{array}$ & $\begin{array}{l}\text { Prog /Exp } \\
\text { ProgxLinh /Exp } \\
\text { Resíduo } \\
\text { CV } \\
\text { Média }\end{array}$ & $\begin{array}{l}245 \\
245 \\
405\end{array}$ & $\begin{array}{c}264,32^{* *} \\
183,89^{* *} \\
94,01 \\
4,87 \\
199,15\end{array}$ & $\begin{array}{c}182,82^{* *} \\
145,91^{* *} \\
76,41 \\
4,03 \\
216,95\end{array}$ & $\begin{array}{c}162,44^{\text {** }} \\
123,04^{\star *} \\
66,16 \\
3,79 \\
214,89\end{array}$ & $\begin{array}{c}104,73^{* *} \\
95,49^{* *} \\
56,42 \\
3,72 \\
202,14\end{array}$ & $\begin{array}{c}134,36^{* *} \\
137,10^{* *} \\
71,25 \\
4,37 \\
193,31\end{array}$ & $\begin{array}{c}151,01^{\text {** }} \\
134,42^{* *} \\
77,12 \\
4,66 \\
188,51\end{array}$ \\
\hline PRE (3) & $\begin{array}{l}\text { Prog /Exp } \\
\text { ProgxLinh /Exp } \\
\text { Resíduo } \\
\text { CV } \\
\text { Média }\end{array}$ & $\begin{array}{l}245 \\
245 \\
405\end{array}$ & $\begin{array}{l}9,02^{* *} \\
7,77^{* *} \\
4,85 \\
4,27 \\
0,52\end{array}$ & $\begin{array}{l}8,49^{* *} \\
5,04^{*} \\
4,15 \\
3,77 \\
0,54\end{array}$ & $\begin{array}{l}9,44^{* *} \\
5,44^{*} \\
4,27 \\
3,67 \\
0,56\end{array}$ & $\begin{array}{l}6,27 \\
5,18 \\
5,71 \\
4,35 \\
0,55\end{array}$ & $\begin{array}{l}8,19 * \\
7,08 \\
6,45 \\
4,78 \\
0,53\end{array}$ & $\begin{array}{l}9,53^{* *} \\
6,65 \\
5,64 \\
4,60 \\
0,52\end{array}$ \\
\hline $\begin{array}{c}\mathrm{FF} \\
\left(\text { dias parcela }^{-1}\right)\end{array}$ & $\begin{array}{l}\text { Prog /Exp } \\
\text { ProgxLinh /Exp } \\
\text { Resíduo } \\
\text { CV } \\
\text { Média }\end{array}$ & $\begin{array}{l}245 \\
245 \\
405\end{array}$ & $\begin{array}{l}--- \\
--- \\
--- \\
--- \\
---\end{array}$ & $\begin{array}{l}5,57^{* *} \\
4,22^{* *} \\
2,76 \\
2,42 \\
68,65\end{array}$ & $\begin{array}{l}5,33^{* *} \\
3,63^{* *} \\
2,58 \\
2,35 \\
68,25\end{array}$ & $\begin{array}{l}4,48^{* *} \\
2,81^{*} \\
2,16 \\
2,27 \\
64,77\end{array}$ & $\begin{array}{l}4,30^{* *} \\
3,03^{* *} \\
2,33 \\
2,28 \\
67,01\end{array}$ & $\begin{array}{l}2,93^{\star *} \\
2,08^{* *} \\
1,52 \\
2,01 \\
61,32\end{array}$ \\
\hline $\begin{array}{c}\text { FM } \\
(\text { dias parcela-1) }\end{array}$ & $\begin{array}{l}\text { Prog /Exp } \\
\text { ProgxLinh /Exp } \\
\text { Resíduo } \\
\text { CV } \\
\text { Média }\end{array}$ & $\begin{array}{l}245 \\
245 \\
405\end{array}$ & $\begin{array}{l}--- \\
--- \\
--- \\
--- \\
---\end{array}$ & $\begin{array}{l}3,91^{\star *} \\
3,02^{* *} \\
2,16 \\
2,18 \\
67,48\end{array}$ & $\begin{array}{l}3,83^{* *} \\
2,08^{* *} \\
1,23 \\
1,66 \\
67,06\end{array}$ & $\begin{array}{l}3,42^{* *} \\
2,20^{\star *} \\
1,49 \\
1,92 \\
63,76\end{array}$ & $\begin{array}{l}3,35^{\star *} \\
2,59^{\star *} \\
1,84 \\
2,03 \\
66,70\end{array}$ & $\begin{array}{l}2,96^{* *} \\
1,72^{* *} \\
1,26 \\
1,83 \\
61,41\end{array}$ \\
\hline IF & $\begin{array}{l}\text { Prog /Exp } \\
\text { ProgxLinh /Exp } \\
\text { Resíduo } \\
\text { CV } \\
\text { Média }\end{array}$ & $\begin{array}{l}245 \\
245 \\
405\end{array}$ & $\begin{array}{l}--- \\
--- \\
--- \\
--- \\
---\end{array}$ & $\begin{array}{r}1,40 \\
1,72 \\
1,47 \\
-103,58 \\
-1,17\end{array}$ & $\begin{array}{r}1,69 \\
1,41 \\
1,65 \\
-108,33 \\
-1,19\end{array}$ & $\begin{array}{r}1,56 \\
1,37 \\
1,48 \\
-120,25 \\
-1,01\end{array}$ & $\begin{array}{r}1,80 * \\
1,42 \\
1,45 \\
-384,71 \\
-0,31\end{array}$ & $\begin{array}{r}1,05^{* *} \\
0,67 \\
0,70 \\
995,94 \\
0,08\end{array}$ \\
\hline $\begin{array}{c}\text { NF } \\
\left(\text { flohas planta }^{-1}\right)\end{array}$ & $\begin{array}{l}\text { Prog /Exp } \\
\text { ProgxLinh /Exp } \\
\text { Resíduo } \\
\text { CV } \\
\text { Média }\end{array}$ & $\begin{array}{l}245 \\
245 \\
405\end{array}$ & $\begin{array}{l}0,25^{* *} \\
0,12 \\
0,11 \\
5,69 \\
5,87\end{array}$ & $\begin{array}{l}0,19^{* *} \\
0,09 \\
0,08 \\
4,55 \\
6,11\end{array}$ & $\begin{array}{l}0,19 * * \\
0,09 \\
0,09 \\
4,90 \\
6,15\end{array}$ & $\begin{array}{l}0,18^{* *} \\
0,09 \\
0,08 \\
4,95 \\
5,87\end{array}$ & $\begin{array}{l}0,22^{* *} \\
0,14^{*} \\
0,11 \\
5,55 \\
6,09\end{array}$ & $\begin{array}{l}0,18^{* *} \\
0,13^{* *} \\
0,10 \\
5,43 \\
5,72\end{array}$ \\
\hline $\begin{array}{l}\text { UM } \\
(\%)\end{array}$ & $\begin{array}{l}\text { Prog /Exp } \\
\text { ProgxLinh /Exp } \\
\text { Resíduo } \\
\text { CV } \\
\text { Média }\end{array}$ & $\begin{array}{l}245 \\
245 \\
405\end{array}$ & $\begin{array}{r}0,17 \\
0,17 \\
0,18 \\
4,12 \\
10,18 \\
\end{array}$ & $\begin{array}{r}0,29 \\
0,30 \\
0,33 \\
5,20 \\
11,12 \\
\end{array}$ & $\begin{array}{r}0,38 \\
0,43 \\
0,36 \\
5,35 \\
11,25\end{array}$ & $\begin{array}{r}0,18 \\
0,21 \\
0,21 \\
3,88 \\
11,73 \\
\end{array}$ & $\begin{array}{r}0,35^{*} \\
0,31 \\
0,28 \\
4,61 \\
11,41 \\
\end{array}$ & $\begin{array}{r}0,25 \\
0,23 \\
0,21 \\
3,84 \\
11,97\end{array}$ \\
\hline
\end{tabular}

(1) Amb 1 refere-se aos experimentos instalados na Estação Experimental do Departamento de Genética (E.E. LGN) durante o no ano agrícola 1999/2000; Amb 2 refere-se à E.E. LGN 1ae época de semeio, Amb 3 à E.E. LGN $2^{2}$ época de semeio, Amb 4 à E.E. Areão, Amb 5 à E.E. Caterpillar e Amb 6 à E.E. LGN $3^{\underline{a}}$ época de semeio; os ambientes de 2 a 6 foram instalados e avaliados durante $o$ ano agrícola 2000/2001. ${ }^{(2)}$ estimativas multiplicadas por $10^{2} ;{ }^{(3)}$ estimativas multiplicadas por $10^{4}$. 
Tabela 21. Covariâncias Cov Prog (P), Cov ProgxAmb (PxA), ), Cov Progxlinh (PxL), Cov ProgxLinhxAmb (PxLXA) e Cov fenotípica (F) originadas das 45 combinações entre os 10 caracteres avaliados.

\begin{tabular}{|c|c|c|c|c|c|}
\hline Caracteres & Cov $\mathrm{P}$ & Cov PxA & Cov PxL & Cov PxLXA & Cov F \\
\hline $\mathrm{PG} \times \mathrm{PRO}^{(2)}$ & 231,58 & 32,49 & 730,75 & 87,46 & 355,67 \\
\hline PGXAE & 173,72 & 82,68 & 615,78 & 136,35 & 204,91 \\
\hline PGXAP & 213,99 & 105,48 & 965,99 & 133,58 & 255,33 \\
\hline $\mathrm{PG} \times \mathrm{PRE}^{(2)}$ & 29,16 & 13,75 & 48,75 & 35,00 & 33,54 \\
\hline PGxFF & $-52,45$ & $-3,36$ & $-129,68$ & 14,03 & $-61,06$ \\
\hline PGxFM & $-43,43$ & $-1,04$ & $-98,80$ & 6,79 & $-49,66$ \\
\hline$P G \times I^{(1)}$ & 90,18 & 23,26 & 308,78 & $-72,20$ & 114,00 \\
\hline$P G \times N F F^{(1)}$ & $-11,51$ & 15,11 & 104,30 & $-0,76$ & $-4,64$ \\
\hline$P G \times U M^{(1)}$ & 16,64 & 25,01 & 49,72 & 1,25 & 22,21 \\
\hline PROXAE ${ }^{(3)}$ & 35,46 & $-6,72$ & 74,00 & $-27,98$ & 37,71 \\
\hline PROXAP $^{(3)}$ & 36,98 & $-2,57$ & 125,36 & $-43,86$ & 39,96 \\
\hline PROXPRE ${ }^{(6)}$ & 73,30 & $-25,10$ & 34,20 & $-25,98$ & 76,88 \\
\hline PROxFF $^{(4)}$ & $-156,11$ & $-3,19$ & $-239,12$ & 24,50 & $-182,72$ \\
\hline $\mathrm{PROxFM}^{(4)}$ & $-108,49$ & $-2,79$ & $-176,51$ & 17,92 & $-129,39$ \\
\hline $\mathrm{PROxIF}^{(4)}$ & 47,62 & 0,40 & 62,61 & $-6,58$ & 53,33 \\
\hline $\mathrm{PROXNF}^{(4)}$ & -17.51 & 1,72 & 22,54 & $-8,36$ & $-16,49$ \\
\hline PROxUM $^{(5)}$ & 90,18 & $-25,33$ & 60,12 & $-101,97$ & 98,16 \\
\hline AEXAP & 1101,42 & 379,26 & 1513,15 & 466,03 & 1353,97 \\
\hline AExPRE $^{(3)}$ & 16,34 & 6,68 & 10,12 & 7,56 & 22,41 \\
\hline $\mathrm{AExFF}^{(2)}$ & $-10,14$ & 4,53 & $-128,40$ & $-1,88$ & $-14,46$ \\
\hline AExFM ${ }^{(2)}$ & 8,52 & 7,82 & $-97,67$ & $-12,28$ & 6,54 \\
\hline $\mathrm{AExIF}^{(2)}$ & 18,67 & 3,29 & 30,74 & $-10,39$ & 21,00 \\
\hline $\mathrm{AExNF}^{(3)}$ & $-87,30$ & 65,26 & 96,03 & $-34,51$ & $-71,27$ \\
\hline $\mathrm{AExUM}^{(3)}$ & $-3,97$ & $-5,77$ & 31,20 & 101,92 & $-2,48$ \\
\hline $\operatorname{APxPRE}^{(4)}$ & 77,43 & 36,89 & 100,63 & 44,86 & 96,18 \\
\hline $\mathrm{APxFF}^{(2)}$ & $-16,13$ & $-3,37$ & $-201,78$ & $-20,31$ & $-22,54$ \\
\hline $\mathrm{APxFM}^{(2)}$ & 13,39 & 5,18 & $-146,27$ & $-23,22$ & 9,01 \\
\hline $\operatorname{APxIF}^{(2)}$ & 29,52 & 8,56 & 55,51 & $-2,89$ & 31,56 \\
\hline $\mathrm{APXNF}^{(2)}$ & 8,31 & 11,84 & 21,02 & $-0,67$ & 12,41 \\
\hline $\mathrm{APxUM}^{(3)}$ & 23,67 & 6,87 & 74,84 & 99,72 & 24,78 \\
\hline PRExFF ${ }^{(5)}$ & $-7,00$ & 37,80 & $-94,95$ & 52,61 & $-11,10$ \\
\hline PRExFM $^{(5)}$ & 6,90 & 29,93 & $-92,20$ & 0,61 & 9,12 \\
\hline PRExIF $^{(5)}$ & 13,91 & $-7,81$ & 2,69 & $-51,69$ & 20,24 \\
\hline PREXNF $^{(5)}$ & $-63,96$ & 0,20 & $-7,43$ & $-16,36$ & $-66,91$ \\
\hline PRExUM $^{(6)}$ & $-83,01$ & $-35,44$ & $-37,19$ & 218,25 & $-76,40$ \\
\hline $\mathrm{FFxFM}^{(2)}$ & 46,13 & 3,85 & 32,64 & 8,31 & 53,19 \\
\hline $\mathrm{FFxIF}^{(3)}$ & $-105,18$ & 41,97 & $-69,87$ & 37,80 & $-147,37$ \\
\hline $\mathrm{FFxNF}^{(4)}$ & 174,68 & 12,47 & $-159,97$ & $-5,98$ & 158,05 \\
\hline $\mathrm{FFxUM}^{(4)}$ & 83,90 & $-53,21$ & $-41,60$ & $-239,81$ & 73,53 \\
\hline $\mathrm{FMxIF}^{(3)}$ & $-41,70$ & 15,97 & $-26,64$ & $-21,46$ & $-21,59$ \\
\hline $\mathrm{FMxNF}^{(4)}$ & 105,62 & 30,29 & $-94,39$ & 54,92 & 90,74 \\
\hline $\mathrm{FMxUM}^{(4)}$ & 56,61 & $-51,96$ & 27,22 & $-132,46$ & 42,47 \\
\hline $\mathrm{IFxNF}^{(4)}$ & $-69,06$ & 17,83 & 65,57 & 60,92 & $-67,31$ \\
\hline IFxUM $^{(4)}$ & $-27,29$ & 1,25 & 68,81 & 107,39 & $-31,06$ \\
\hline $\mathrm{NFxUM}^{(4)}$ & 29,05 & 18,96 & 27,56 & $-26,62$ & 31,63 \\
\hline
\end{tabular}

estimativas multiplicadas por 10; (2) estimativas multiplicadas por $10^{2}$; ${ }^{(3)}$ estimativas multiplicadas por $10^{3} ;{ }^{(4)}$ estimativas multiplicadas por $10^{2} ;{ }^{(4)}$ estimativas multiplicadas por $10^{4} ;{ }^{(5)}$ estimativas multiplicadas por $10^{5} ;{ }^{(6)}$ estimativas multiplicadas por $10^{6}$. 